UNIVERSIDAD POLITÉCNICA DE MADRID

ESCUELA TÉCNICA SUPERIOR DE INGENIEROS DE CAMINOS, CANALES Y PUERTOS

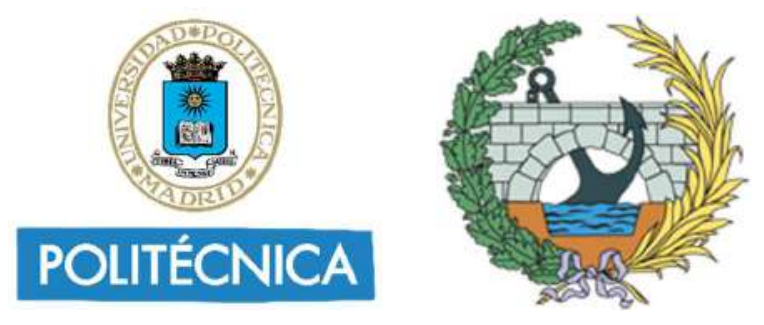

\title{
ANÁLISIS DEL IMPACTO DE LOS SISTEMAS DE FREE-FLOATING CARSHARING EN ENTORNOS URBANOS UTILIZANDO DATOS WEB: APLICACIÓN A LA CIUDAD DE MADRID
}

\author{
TESIS DOCTORAL
}

\author{
MARÍA AMPUDIA RENUNCIO \\ Grado en Ingeniería de Tecnologías de Caminos \\ Máster Universitario en Ingeniería de Caminos, Canales y Puertos
}

Madrid, 2020 


\title{
DEPARTAMENTO DE INGENIERÍA DEL TRANSPORTE, TERRITORIO Y URBANISMO

\author{
ESCUELA TÉCNICA SUPERIOR DE INGENIEROS \\ DE CAMINOS, CANALES Y PUERTOS
}

TESIS DOCTORAL

\section{ANÁLISIS DEL IMPACTO DE LOS SISTEMAS DE FREE-FLOATING CARSHARING EN ENTORNOS URBANOS UTILIZANDO DATOS WEB: APLICACIÓN A LA CIUDAD DE MADRID}

\author{
MARÍA AMPUDIA RENUNCIO \\ Grado en Ingeniería de Tecnologías de Caminos \\ Máster Universitario en Ingeniería de Caminos, Canales y Puertos
}

Director:

Begoña Guirao Abad

Dr. Ingeniero de Caminos, Canales y Puertos

Madrid, 2020 


\section{POLITÉCNICA}

Tribunal nombrado por el Excelentísimo y Magnífico Sr. Rector de la Universidad Politécnica de Madrid, el día de de 2020.

Presidente:

Vocal:

Vocal:

Vocal:

Secretario:

Suplente:

Suplente:

Realizado el acto de defensa y lectura de la Tesis el día de de 2020 en la E.T.S. de Ingenieros de Caminos, Canales y Puertos de la Universidad Politécnica de Madrid.

Acuerda otorgarle la calificación de:

Madrid, de de 2020

EL PRESIDENTE LOS VOCALES

\section{EL SECRETARIO}




\section{AGRADECIMIENTOS}

Quisiera empezar expresando mi agradecimiento a todos aquellos profesores que han estado presentes a lo largo de mi trayectoria académica, empezando por el colegio, hasta completar el Grado en Ingeniería de Tecnologías de Caminos en la Universidad de Burgos y el Máster en Ingeniería de Caminos, Canales y Puertos en la Universidad Politécnica de Madrid. De todos estos años quisiera destacar tanto la formación recibida que me ha hecho convertirme en Ingeniero, como los valores inculcados que han contribuido a mi crecimiento personal.

Quiero agradecer a mi Director de tesis Begoña Guirao su confianza en mí desde el principio para llevar a cabo esta investigación. Gracias a su dedicación, perseverancia y apoyo, que han hecho posible la realización de este trabajo. También quiero agradecer al Profesor Rafael Molina el apoyo y la ayuda prestada, indispensables en el desarrollo de esta investigación.

Por último, y para mi fundamental, quiero dar las gracias a mi familia. En especial, a mis padres por su ilusión y por su apoyo para seguir siempre adelante y luchar por conseguir todas mis metas. A Cris y a Gon, por ser mi referente y ejemplo. Y a Nacho, por su paciencia y cariño.

Gracias. 


\section{Índice}

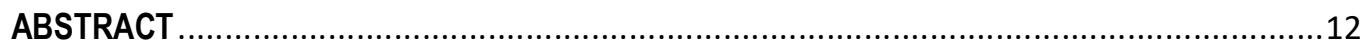

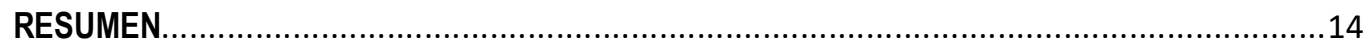

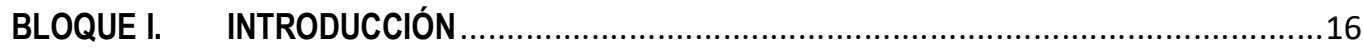

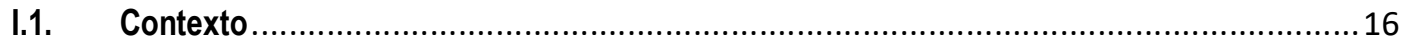

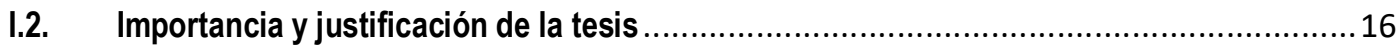

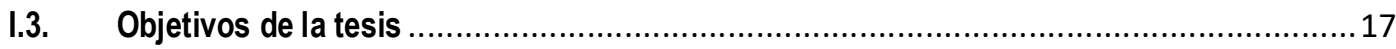

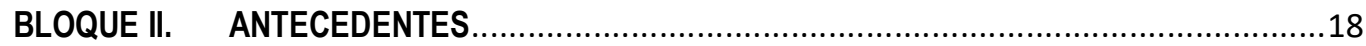

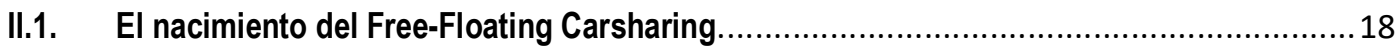

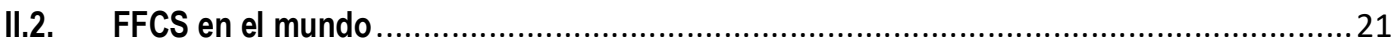

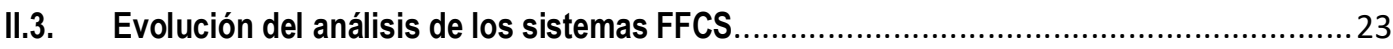

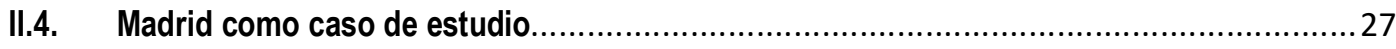

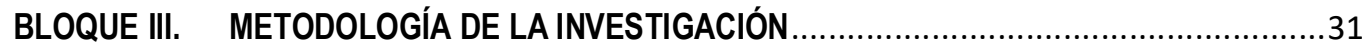

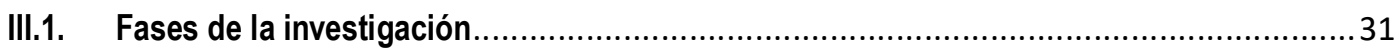

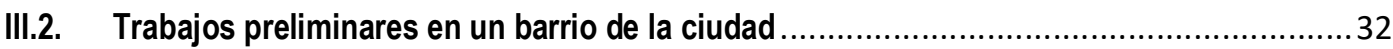

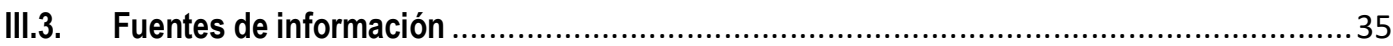

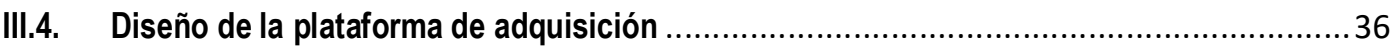

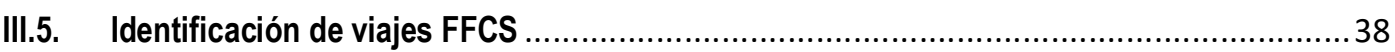

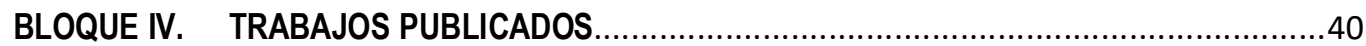

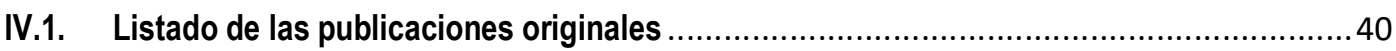

IV.2. Artículo I: The Impact Of Free-Floating Carsharing On Sustainable Cities: Analysis Of First Experiences In Madrid With The University Campus..

IV.3. Artículo II: Understanding The Spatial Distribution Of Free-Floating Carsharing In Cities: Analysis Of The New Madrid Experience Through A Web-Based Platform. ................................5 55

IV.4. Artículo III: Electric Free-Floating Carsharing For Sustainable Cities: Characterization Of

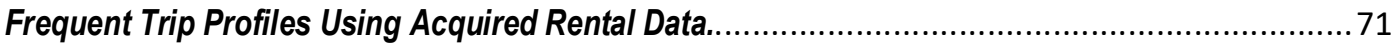

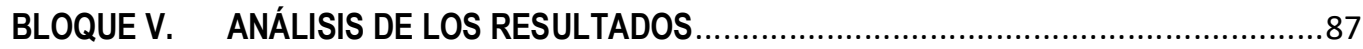

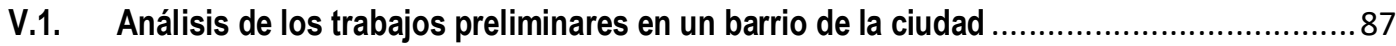

V.2. Análisis de la distribución espacio-temporal de los viajes y patrones de uso...................93

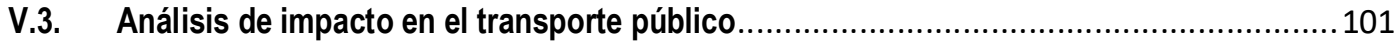

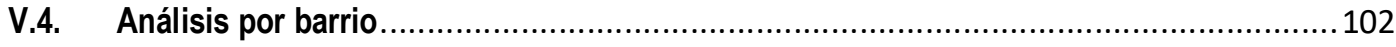

BLOQUE VI. CONCLUSIONES Y FUTURAS LÍNEAS DE INVESTIGACIÓN .........................109

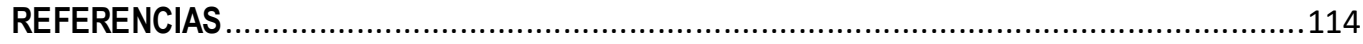




\section{Índice de figuras}

Figura 1. Nacimiento y evolución del carsharing hasta el FFCS (elaboración propia en base a información expuesta por Shaheen y Micheaux, 2015). 18

Figura 2. Relaciones entre características de las ciudades donde operaba Car2go en 2017: (a) población de la ciudad y flota de Car2go, (b) área de la ciudad y flota de Car2go, (b) población de la ciudad y usuarios registrados en Car2go y (d) densidad de población de la ciudad y flota de Car2go (elaboración propia en base a datos de la operadora Car2go) .22

Figura 3. Zonas de servicio de los sistemas FFCS en el momento de la adquisición de datos. Se señalan los barrios situados en su interior, de acuerdo con la numeración de los distritos en

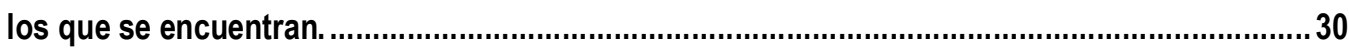

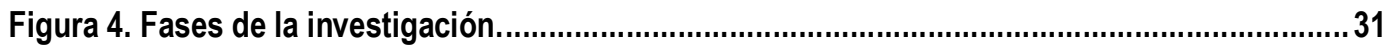

Figura 5. Vista de la interfaz de la plataforma CarTrack. .38

Figura 6. Evolución de la disponibilidad de los vehículos Car2go en Ciudad Universitaria en la semana del 3 al 9 de octubre de 2016: (a) Representación de toda la semana, (b) Representación de los días de la semana superpuestos.

Figura 7. Resultados de la encuesta realizada, comparados con una encuesta similar llevada a cabo en Hamburgo. Aceptación de la disponibilidad y de las estrategias de recolocación de vehículos de los encuestados en (a) Madrid y (b) Hamburgo. (c) Aceptación de la disponibilidad de usuarios y no usuarios en Madrid. .89

Figura 8. Vehículos de Car2go disponibles en función de la distancia a la que se encuentran de la puerta principal de la Escuela de Caminos, Canales y Puertos en el campus de Ciudad Universitaria. 91

Figura 9. Reservas y alquileres diarios de Car2go y Emov durante el periodo de estudio. 93

Figura 10. Promedio de viajes por día de la semana y por operador: (a) lunes a jueves, (b) viernes, (c) sábado y (d) domingo. .95

Figura 11. (a) Duración en minutos de los alquileres (reservas en las que sí se produjo un viaje).

(b) Duración en minutos de las reservas en las que no se produjo un viaje. .97

Figura 12. Frecuencia de los orígenes (a) y destinos (b) de los viajes FFCS analizados. .98

Figura 13. Flujos 0-D más frecuentes: (a) de lunes a viernes de 7:00 a 9:59 h y (b) de lunes a viernes de 13:00 a 15:59 $\mathrm{h}$. .99

Figura 14. Flujos O-D más frecuentes en la franja horaria de 18:00 a 20:59 h: (a) de lunes a jueves, (b) viernes, (c) sábado y (d) domingo. 100

Figura 15. (a) Comparación de tiempos de viaje en coche de FFCS y en transporte público de los pares O-D más frecuentes durante el periodo punta de la mañana. (b) Incremento de tiempo de viaje en transporte público comparado con el tiempo de viaje en FFCS durante el periodo punta 
de la mañana. (c) Incremento de coste de viaje en FFCS respecto al coste del viaje en transporte público. . 102

Figura 16. Alquileres producidos en cada barrio en el periodo de tiempo estudiado (los códigos de los barrios se indican en la Figura 3). 103

Figura 17. Proporción de viajes con origen y destino en el mismo barrio frente a viajes con origen $y$ destino en en distintos barrios en (a) viajes que duran hasta 15 minutos y (b) viajes que duran más de 15 minutos. 103

Figura 18. (a) Frecuencias de viajes y (b) pares Origen-Destino mas frecuentes en función de la duración del viaje (se han excluido los viajes con origen y destino en el mismo barrio). 105

Figura 19. Promedio de viajes en día laborable y ubicación de las coordenadas de origen de los viajes durante el periodo de tiempo estudiado en (a) EI Viso (051), (b) Ciudad Universitaria (093) y (c) Cuatro Caminos (062) 


\section{ABSTRACT}

In recent years, different sharing economy business models have been implemented in urban environments with the aim of improving the mobility of citizens and optimizing their transport costs. Among them, car sharing systems have evolved towards what we know today as Free-Floating Carsharing (FFCS), more flexible for users than stationbased systems, but strongly conditioned by parking availability and local administration management.

While literature about traditional carsharing is extensive and several authors have proved its effects in improving urban mobility and reducing environmental pollution, more research work is needed to assess the impacts of FFCS in cities. The papers derived from this doctoral thesis have contributed to enriching the existing literature about the subject worldwide, and they provide a first analysis of the performance of these systems in Spain and, more specifically, in the city of Madrid.

The methodology used has progressed over the course of the research. In a preliminary phase of exploratory analysis, it was based on both a survey campaign and a systematic image capture from the website of the first operator to implement its system in the city (Car2go). The scenario was focused on a limited area of the city, the university campus, and on getting to know the FFCS behavior of a specific population group: university students. Results showed that there is a strong dependence on the quality attributes of FFCS, especially on the vehicle availability when the user needs it. This attribute is a key issue to attract users and it is very important to know the acceptable distance to walk and time to wait that users are willing to assume, in the search for an available vehicle.

After this pilot experience in a neighborhood characterized by university students, the research evolved towards the spatial and temporal analysis of FFCS trips throughout the city, using data acquired from the information displayed by two operators (Car2go and Emov) on their websites. Due to the difficulties in obtaining real trip records provided directly by them, the acquisition of web data was considered the best source of information in order to get a better understanding of the operation of these systems, despite requiring a comprehensive process of trip identification based on scientific hypotheses. The study of the temporal profile of trips helped to identify the peculiarities of this transportation mode in Madrid, in contrast to other modes and other cities, while the spatial analysis revealed the preponderance of short-distance trips in which time 
savings are considerable in comparison with public transportation trips. Subsequently, the operation and usage patterns of FFCS in specific neighborhoods of the city were assessed, showing that the areas with the highest utilization rates were high- or medium-income neighborhoods, with a high parking supply and good connectivity with urban road infrastructure. 


\section{RESUMEN}

En los últimos años, distintos modelos de negocio colaborativos se han implantado en entornos urbanos con el objetivo de facilitar la movilidad de los ciudadanos y optimizar sus costes de transporte. Entre ellos, los sistemas de coches compartido han evolucionado hasta lo que conocemos hoy en día como Free-Floating Carsharing (FFCS), más flexible para el usuario que los sistemas basados en estaciones, pero fuertemente condicionado por la disponibilidad de aparcamiento y la gestión de las administraciones locales.

Mientras que el estado del arte del carsharing tradicional es extenso y numerosos autores han demostrado sus efectos en la mejora de la movilidad urbana y la reducción de la contaminación medioambiental, se requiere más trabajo de investigación para evaluar los impactos del FFCS en las ciudades. Esta tesis por artículos ha contribuido a enriquecer la literatura existente al respecto a nivel mundial y proporciona un primer estudio del funcionamiento de estos sistemas en España y, más concretamente, en la ciudad de Madrid.

La metodología utilizada ha evolucionado a lo largo del desarrollo de la investigación. En una fase preliminar de análisis exploratorio, se partió de una campaña de encuestas y de la toma sistematizada de imágenes de la web del primer operador que implantó su sistema en la ciudad (Car2go). El escenario de la investigación se centró en una zona concreta de la ciudad, el campus de Ciudad Universitaria, y en conocer el comportamiento respecto al FFCS de un grupo de población específico: los estudiantes universitarios. Los resultados indicaron que existe una fuerte dependencia de los atributos de calidad del FFCS, en concreto de la disponibilidad de vehículos en el instante de búsqueda por parte del usuario. Este atributo es clave para captar usuarios y resulta muy importante conocer la distancia y tiempo límites que éstos estarían dispuestos a andar y caminar, respectivamente, en la búsqueda de un vehículo disponible.

Después de esta experiencia piloto en un barrio caracterizado por estudiantes universitarios, la investigación evolucionó hacia el análisis espacio-temporal de los viajes de FFCS en toda ciudad, a partir de la adquisición de los datos puestos a disposición de los usuarios de dos operadores (Car2go y Emov) en sus páginas web. Debido a las dificultades para la obtención de registros de viajes reales proporcionados directamente por estos, la adquisición de datos web fue considerada la 
mejor fuente de información para tener un mayor conocimiento del funcionamiento de estos sistemas, a pesar de requerir un proceso exhaustivo de identificación de viajes basado en hipótesis científicas. El estudio del perfil temporal de los viajes sirvió para identificar las peculiaridades de este modo de transporte en Madrid respecto a otros modos y otras ciudades, mientras que el análisis espacial reveló la preponderancia de viajes de corta distancia en los que el ahorro de tiempo respecto al transporte público es considerable. Posteriormente, se evaluó el funcionamiento y los patrones de uso del FFCS en barrios concretos de la ciudad, mostrando que las zonas con mayores tasas de utilización son vecindarios de renta media-alta, con alta oferta de aparcamiento y buena conectividad con la infraestructura vial urbana. 


\section{BLOQUE I. INTRODUCCIÓN}

\section{I.1. CONTEXTO}

Uno de los principales retos a los que se enfrentan en la actualidad los responsables de la planificación y la gestión del transporte es la promoción de un transporte sostenible, que aúne el desarrollo económico con el bienestar social y la protección del medioambiente. El transporte siempre ha sido considerado un motor de la economía y es esencial para el desarrollo de un territorio. Sin embargo, el impacto que esta actividad está generando en el medio ambiente está desarrollando una preocupación a nivel global que impulsa el desarrollo de modos de transporte más sostenibles.

Puede considerarse que las grandes ciudades están a la cabeza en la adopción de esta tendencia. Además de los serios efectos medioambientales originados por las emisiones de gases de efecto invernadero, deben enfrentarse a problemas de espacio y congestión causados por la alta densidad de población y una tasa de motorización cada vez más alta. Una situación que, de no hacer nada, se agravará, puesto que se espera que, para el año 2050 , un $68 \%$ de la población mundial vivirá en zonas urbanas, aunque dicho crecimiento será más acusado en Asia y África (Naciones Unidas, 2018). En el Primer Mundo, donde gran parte de la población ya se concentra en ciudades (según Naciones Unidas (2018), 82\% en América del Norte y $74 \%$ en Europa), la movilidad urbana ya está cambiando. La irrupción de la economía colaborativa (Sharing economy) ha supuesto la creación de nuevos modelos de negocio, también en el sector de la movilidad. Las nuevas generaciones de consumidores demandan los "sistemas producto-servicio", esto es, el acceso temporal a un bien del que se benefician sin la necesidad de adquirilo (Botsman y Rogers, 2010). La movilidad compartida plantea un nuevo escenario para los planificadores de transporte, que están adoptando medidas que restringen la circulación del vehículo privado en favor de otros modos más sostenibles, pero aún queda pendiente definir las estrategias a seguir para integrarlos en las redes de transporte convencionales, lo que se conoce como Mobility as a Service (MaaS).

\section{I.2. IMPORTANCIA Y JUSTIFICACIÓN DE LA TESIS}

Entre los nuevos modos de transporte que están irrumpiendo en las grandes ciudades, uno de los que está experimentando más éxito y está captando a un amplio espectro de usuarios son los sistemas de Free-Floating Carsharing (FFCS). Esta modalidad de sistema de coche compartido surgió hace algo más de una década, pero ha sido en los últimos años cuando su implantación se ha extendido por todo el mundo y ha llamado la atención de la comunidad científica, que se ha empezado a plantear cuál es el impacto que estos sistemas están generando en las ciudades. Esta tesis trata de dar respuesta a algunas de las cuestiones que han surgido acerca de estos sistemas: 
¿Cómo son los patrones de utilización y el perfil de usuario? ¿Cuál es el impacto que están generando en el viario público, especialmente en la infraestructura de estacionamiento? ¿Está provocando un impacto en la utilización del transporte público?

Para el desarrollo de esta investigación se ha escogido el caso de Madrid, elección motivada por ser un lugar en el que operan varias compañías de FFCS que utilizan flotas de vehículos eléctricos y en el que aún no se habían llevado a cabo investigaciones al respecto. Madrid cuenta con una regulación de aparcamiento en la vía pública que favorece la implementación del FFCS eléctrico y tiene una densa red de transporte público que funciona con eficacia.

Sin embargo, las peculiaridades de la capital española, de su configuración urbana y de los sistemas de transporte existentes pueden implicar que los resultados de esta investigación, a priori, no puedan escalarse a otros ámbitos. Los diferentes patrones de utilización entre ciudades de los sistemas de transporte público o de otros modos de uso generalizado, como las bicicletas o motocicletas, hacen pensar que el uso del FFCS también se vea condicionado por las características del lugar y el comportamiento de sus ciudadanos.

\section{I.3. OBJETIVOS DE LA TESIS}

El objetivo general de esta tesis se centra en evaluar los impactos que los sistemas de Free-Floating Carsharing generan sobre la demanda (el perfil de usuario), el sistema de transporte urbano y la oferta de aparcamiento en el viario público.

Este objetivo general se ha desagregado en los siguientes objetivos específicos:

- Analizar las características de la oferta de los sistemas Free-Floating Carsharing, estudiando sus peculiaridades como nuevo modelo de transporte y su impacto sobre la oferta de aparcamiento en el viario público.

- Identificar y recolectar de forma sistemática flujos de tráfico de FFCS, utilizando datos web ofrecidos por las empresas operadoras.

- Caracterizar los viajes en FFCS, analizando la distribución espacio-temporal de los mismos en la ciudad y estudiando patrones de uso de los sistemas FFCS.

- Llevar a cabo un análisis desagregado de los viajes a nivel de barrio o distrito, seleccionando aquellos barrios entre los que existe un mayor tráfico de FFCS. 


\section{BLOQUE II. ANTECEDENTES}

\section{II.1. EL NACIMIENTO DEL FREE-FLOATING CARSHARING}

Los sistemas de coche compartido, incluidos bajo el paraguas de la economía colaborativa y conocidos por el término en inglés carsharing, llevan varias décadas desarrollándose. La primera experiencia conocida de uso compartido de vehículos fue la de una cooperativa suiza a mediados del siglo pasado, motivada por la idea de que una flota de coches pudiera ser utilizada por varios usuarios, que podían conducir un coche cuando lo necesitaran sin necesidad de poseerlo (Ciari, Bock y Balmer, 2014; Shaheen, Sperling y Wagner, 1998). Posteriormente, la idea fue replicada, con mayor o menor éxito, en diversas ciudades europeas y fue evolucionado hasta los sistemas que conocemos en la actualidad debido, tanto a las nuevas demandas de la sociedad como al desarrollo de nuevas tecnologías.

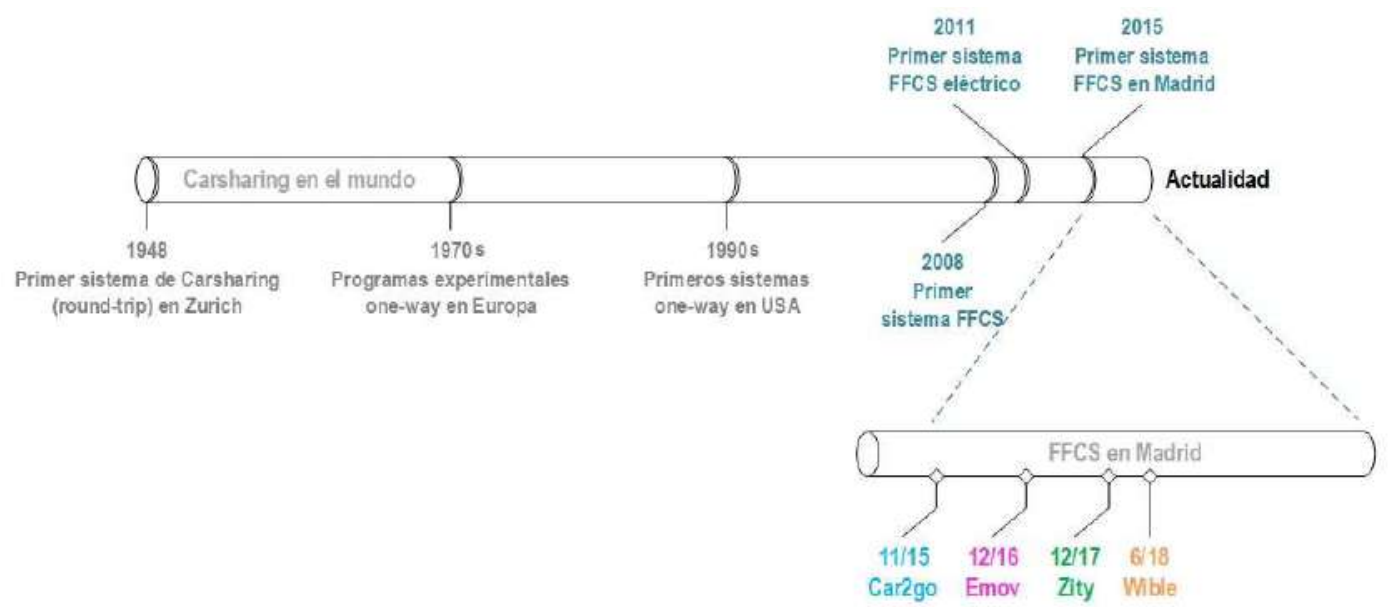

Figura 1. Nacimiento y evolución del carsharing hasta el FFCS (elaboración propia en base a información expuesta por Shaheen y Micheaux, 2015).

El carsharing, de forma genérica, podría definirse como "una práctica en la que varias personas en una organización, con o sin fines de lucro, comparten el uso de varios vehículos a cambio de una tarifa" (Millard-Ball et al., 2005). Esta tarifa puede englobar una tasa de inscripción o un importe fijo por viaje, además de una tasa variable que, generalmente, depende del tiempo de uso del servicio.

Tradicionalmente, las empresas operadoras de carsharing se han apoyado en un número determinado de estaciones fijas distribuidas donde los usuarios deben empezar y finalizar el viaje. Por eso, este tipo de sistema se conoce como StationBased Carsharing y requiere un trámite previo para reservar el vehículo con antelación. Generalmente, el uso de estos vehículos es round-trip, es decir, el vehículo debe ser devuelto en la estación en la que fue alquilado, pero en ocasiones puede ser one-way, dejando la opción de entregarlo en una estación distinta, lo que puede llevar a generar asimetrías en su distribución espacial. 
Sin embargo, en la última década ha proliferado una forma distinta de compartir vehículo: el Free-Floating Carsharing (FFCS). Este tipo de sistema permite alquilar un coche directamente en la calle y devolverlo en cualquier ubicación, siempre que esté bien estacionado y se encuentre dentro de un área de servicio predeterminada. De este modo, los usuarios pueden empezar y acabar el trayecto más cerca del origen y el destino final de su viaje, respectivamente. Este incremento de flexibilidad respecto a los sistemas tradicionales ha contribuido a su expansión en las grandes ciudades de todo el mundo y el mismo modelo de negocio ha sido implementado con otros tipos de vehículos, como motos, bicicletas o patinetes.

Aunque la flexibilidad es una característica diferenciadora del FFCS que atrae a nuevos usuarios, otro factor que contribuye a mantener su éxito en viajes posteriores es la disponibilidad. Si un cliente experimenta con frecuencia que no hay vehículos disponibles cerca del origen de su viaje, cada vez que vaya a iniciar un viaje no se planteará usar este sistema, en favor de otros modos de transporte más fiables. Es más, incluso cuando ya se ha hecho el trayecto de ida en un coche FFCS, el sistema no garantiza que haya coches disponibles para realizar el viaje de vuelta o el viaje a la siguiente actividad. La calidad del servicio y su fiabilidad dependen estrechamente de que haya una buena disponibilidad espacial de vehículos (Niels y Bogenberger, 2017). Para garantizarla, no solo es necesario asegurar una cantidad mínima de vehículos en el área de servicio, sino también aplicar estrategias operativas de recolocación de los vehículos de aquellas zonas atractoras a zonas generadoras, analizando los patrones de movilidad espacial en función de la dimensión temporal de los viajes. Incentivar a los usuarios que colaboren en la recolocación de los vehículos podría generar ahorros al operador, al reducir sus costes de operación por no efectuar internamente dicha tarea. Herrmann, Schulte y Voß (2014) ya propusieron estrategias de este tipo: reducir tarifas a aquellos usuarios que alquilasen vehículos más distantes, que finalizasen el viaje en zonas más alejadas, que realizaran rutas específicas o que compartieran el viaje con otros usuarios, informando de antemano el destino del viaje.

Las Tecnologías de la Información y la Comunicación (TICs) han jugado un papel indispensable en el desarrollo del FFCS, tal y como lo conocemos hoy en día. Las mejoras tecnológicas han desencadenado la creación de sistemas de gestión de flotas de transporte público basados en el geoposicionamiento de los vehículos, que permiten suministrar información en tiempo real a los usuarios y la optimización de rutas y horarios (Guirao et al., 2015). En el caso del FFCS (y de otros sistemas de movilidad colaborativa), la dependencia de estas tecnologías va más allá, siendo indispensables para el desempeño del servicio. Gracias a una aplicación para dispositivos móviles, los usuarios pueden consultar en tiempo real la ubicación y el estado de los vehículos disponibles, reservar el vehículo elegido durante un tiempo limitado e iniciar y finalizar el viaje.

Otra tecnología que se ha desarrollado y generalizado su uso y que, si bien no es indispensable en la operación de los sistemas de FFCS, ha fomentado su expansión y 


\section{ANÁLISIS DEL IMPACTO DE LOS SISTEMAS DE FREE-FLOATING CARSHARING EN ENTORNOS URBANOS UTILIZANDO DATOS WEB: APLICACIÓN A LA CIUDAD DE MADRID}

ha contribuido en su éxito son los vehículos con motor eléctrico. Es evidente que generan un impacto positivo en la calidad del aire de las ciudades y, en muchos casos, los Ayuntamientos ofrecen incentivos para su utilización, de los que se aprovechan las compañías que gestionan estos sistemas. Sin embargo, las experiencias con vehículos eléctricos revelan que su limitada autonomía es una preocupación para los clientes, conocida como range anxiety (Wielinski, Trepanier y Morency, 2017). comportamiento de los usuarios de coches eléctricos de batería (BEV, Battery Electric Vehicles) difiere de aquellos que utilizan coches con motor de combustión interna o incluso híbridos enchufables (PHEV, Plug-in Hybrid Electric Vehicles) (Müller, Schmöller y Giesel, 2015), debido a la percepción pesimista que normalmente tiene el conductor de que la carga de la batería no va a ser suficiente para llegar al destino deseado. Wielinski, Trepanier y Morency (2017) analizaron los patrones de elección de los usuarios de una flota de FFCS con vehículos tanto eléctricos como híbridos, concluyendo que la distancia del viaje es un factor determinante en la elección. El análisis espacial de los viajes mostró una diferencia de comportamiento en función del tipo de vehículo: los viajes en coche eléctrico resultaron tener menor dispersión espacial que los efectuados en híbrido. Se espera que, a medida que los usuarios se habitúen a la conducción de coches eléctricos y las baterías se desarrollen garantizando una mayor autonomía, esta preocupación se reduzca o cese.

Por otro lado, el uso de flotas eléctricas de FFCS ha sido impulsada por la industria automotriz, que está detrás de los principales operadores de FFCS, como una estrategia comercial y de marketing. Vaskelainen y Münzel (2018) que es la propia estrategia corporativa de las firmas automovilísticas la que impulsa el desarrollo del FFCS en una dirección, a diferencia de la trayectoria seguida por los sistemas tradicionales que están operados por organizaciones de menor tamaño.

El concepto del FFCS como un "sistema producto-servicio" ha sido respaldado precisamente por las firmas automovilísticas (Firnkorn, 2012), que ven que la combinación de servicios y productos podría generar mayor beneficio que solo con la venta de productos. Esto es, han pasado de perseguir objetivos como incrementos en las ventas de coches, a poner el foco en otras actividades, como el FFCS. De este modo, además de diversificar el negocio, indirectamente se están generando oportunidades de creación de valor añadido en la actividad tradicional del sector. Firnkorn y Müller (2011a) indican que esta "expansión estratégica" no solo responde a la creencia en una nueva oportunidad, sino también a las amenazas que pueden afectar al modelo de negocio tradicional por tratarse un mercado de productos maduros, por la presión de las instituciones gubernamentales y por el cambio en la percepción de los consumidores. Todo parece indicar que el uso de vehículos eléctricos en sistemas FFCS, podría llevar a que sus usuarios en un futuro se planteen la compra de un coche eléctrico, puesto que ya ha experimentado la conducción diferenciada de este tipo de vehículo. 


\section{II.2. FFCS EN EL MUNDO}

El primer sistema FFCS fue implantado en 2008 por la empresa Car2go, una filial de Daimler AG, en una pequeña ciudad alemana llamada Ulm (Firnkorn y Müller, 2011b; Kortum et al., 2016). Desde entonces, Car2go se fue expandiendo por el mundo. A comienzos de 2018, operaba en 13 ciudades europeas y 11 ciudades en Estados Unidos y Canadá y una en Asia, con una flota de 14.000 coches Smart y Mercedes y había alcanzado la cifra de tres millones de usuarios registados (Car2go blog, 2018a). Car2go fue también pionera en el FFCS de Madrid: en noviembre de 2015 lanzó el primer sistema de la capital española.

En 2011 surgió el que sería su principal competidor durante unos años: DriveNow (conocida como ReachNow en Estados Unidos), también de origen alemán y filial de otro grande de la industria automovilística, el grupo BMW (Kopp, Gerike y Axhausen, 2015; Kortum et al., 2016; Müller, Correia y Bogenberger, 2017). A finales de 2017, había superado el millón de usuarios registrados y se encontraba funcionando en 13 ciudades europeas y tres norteamericanas con una flota de unos 8.000 vehículos (DriveNow blog, 2017). En 2018, Daimler y BMW acordaron fusionar sus servicios de movilidad (Car2go blog, 2018b), formándose ShareNow, marca que comenzó a operar en 2019.

Con el paso de los años, han surgido otros operadores de FFCS que están presentes en menor número de ciudades, pero que también han sido impulsados por la industria automovilística, como los sistemas creados por Grupo PSA (PSA Group, 2017) o por Grupo Hyundai (Hyundai Motor Europe, 2017).

Tras revisar diferentes estudios, ninguno de ellos se había enfocado hacia el análisis de las variables que podían tener relación directa con el uso de los sistemas de FFCS. Por ello, en la etapa inicial de esta tesis, se acometió un análisis que pretendía encontrar aquellas variables que podrían tener una relación directa con un mayor uso de los sistemas de FFCS. Para ello, se escogieron variables intrínsecas de la ciudad (población o superficie) y otras relacionadas, bien con la oferta del sistema de FFCS (vehículos en la flota) o bien con su demanda (número de usuarios), y se compararon para las ciudades en las que operaba Car2go en ese momento: once norteamericanas y trece europeas, incluida Madrid. El objetivo fue tratar de evaluar las características que hacen a una ciudad idónea para implantar este tipo de servicio. Los gráficos muestran un grupo heterogéneo de situaciones y no revelan la existencia de una relación lineal de dependencia entre las variables: población de la ciudad, densidad de población, número de usuarios y número de vehículos en la flota FFCS (Figura 22). Hubiera sido interesante evaluar otros aspectos como la superficie del área de servicio del operador con el fin de poder obtener, en la comparación con la flota del sistema, un ratio de vehículos por $\mathrm{km}^{2}$ más homogéneo. Sin embargo, esta información no estaba disponible dentro de la información proporcionada por el operador y se recurrió a la superficie completa de la ciudad (Figura 22 b). 


\section{ANÁLISIS DEL IMPACTO DE LOS SISTEMAS DE FREE-FLOATING CARSHARING EN ENTORNOS URBANOS UTILIZANDO DATOS WEB: APLICACIÓN A LA CIUDAD DE MADRID}

Es difícil identificar patrones claros de comportamiento que diferencien ciudades europeas y norteamericanas, probablemente porque se requiere información adicional como la calidad del transporte público y porque hay algunas ciudades en la muestra con otros operadores de FFCS, además de Car2go.

En muchas de estas ciudades, Car2go utiliza el modelo biplaza de Smart (Fortwo) o el de cuatro plazas (Forfour), como en el caso de Madrid. Debido a su compacidad, estos vehículos son apropiados para moverse y aparcar en ciudades congestionadas con limitado espacio de aparcamiento en el viario. En el caso de Madrid, las regulaciones de aparcamiento facilitan el aparcamiento de los vehículos eléctricos, lo que ha propiciado la implantación de estos sistemas con flotas completamente eléctricas. No obstante, en el año 2017, solo había otros dos sistemas operados por Car2go con flotas totalmente eléctricas: en las ciudades de Stuttgart y Amsterdam. Además, las tarifas durante los primeros años de operación de la compañía en Madrid fueron inferiores a las del resto de las ciudades, lo que hizo que el sistema fuera muy atractivo para nuevos usuarios.

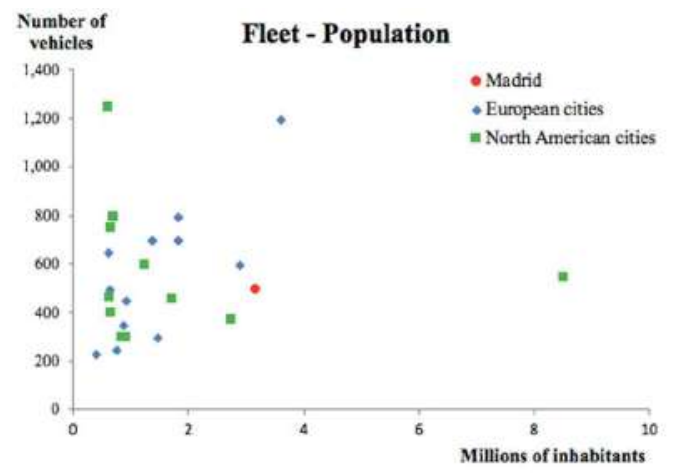

(a)

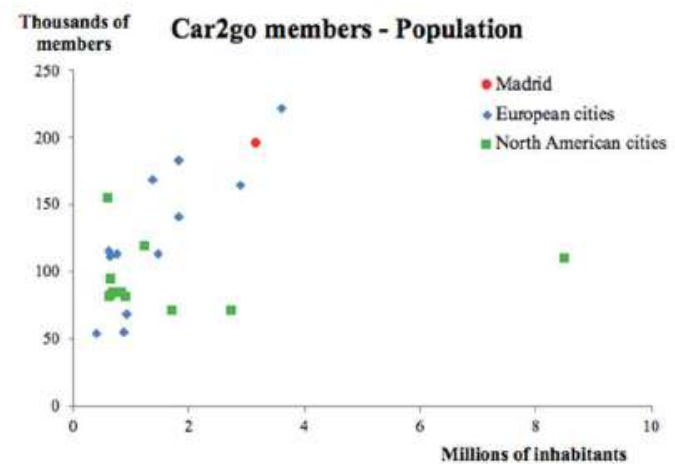

(c)

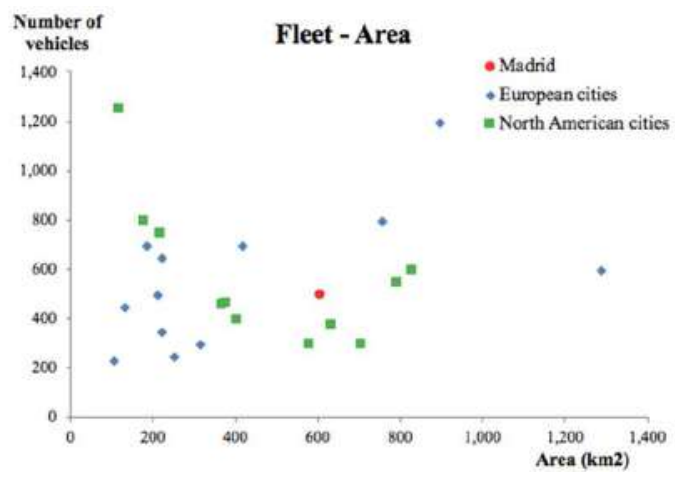

(b)

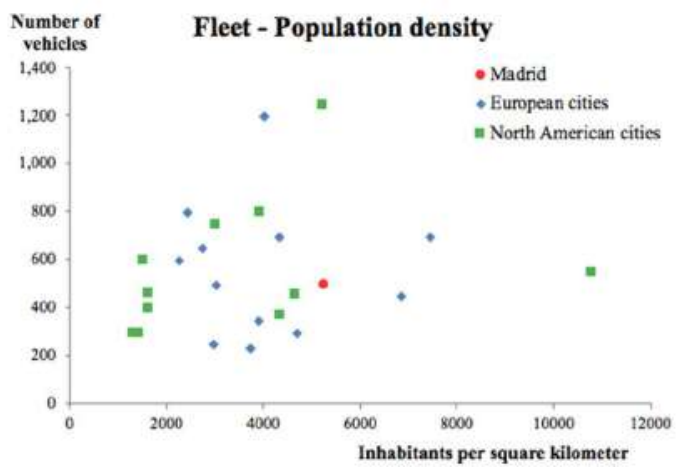

(d)

Figura 2. Relaciones entre características de las ciudades donde operaba Car2go en 2017: (a) población de la ciudad y flota de Car2go, (b) área de la ciudad y flota de Car2go, (b) población de la ciudad y usuarios registrados en Car2go y (d) densidad de población de la ciudad y flota de Car2go (elaboración propia en base a datos de la operadora Car2go). 


\section{II.3. EVOLUCIÓN DEL ANÁLISIS DE LOS SISTEMAS FFCS}

A pesar de que los sistemas de coche compartido flotante tengan su origen en los sistemas basados en estaciones, los resultados obtenidos en investigaciones recogidas en la literatura que analizan los impactos del station-based carsharing, no pueden ser aplicados directamente al FFCS (Firnkorn y Müller, 2011b). Entre otros, la comunidad científica había aceptado algunos efectos positivos de los sistemas tradicionales, como su contribución a la reducción de las emisiones de gases nocivos para el medioambiente (Shaheen y Cohen, 2007; Haefeli et al., 2006); a la reducción de distancia individual recorrida en coche, conocido con las siglas VKT (VehicleKilometres Traveled) (Shaheen, Cohen y Chung, 2009); y a la disminución del número medio de vehículos por hogar (Martin y Shaheen, 2011). No obstante, las diferentes condiciones de utilización que ofrece el FFCS, con distinta estructura tarifaria y mayor flexibilidad para el usuario, hacen pensar que sus efectos no sean los mismos. Estos sistemas han evolucionado gracias al desarrollo de las nuevas tecnologías y han sabido adaptarse a las demandas de los usuarios, lo que ha llevado a captar a un amplio espectro de la población, de modo que, probablemente, muchos de los nuevos usuarios no hubieran sido atraídos por los sistemas de carsharing previos (Becker, Ciari y Axhausen, 2017; Kopp, Gerike y Axhausen, 2015). El impacto global de los sistemas de carsharing tradicional se calculaba como la suma de los impactos individuales de todos los usuarios. Sin embargo, un incremento en el número de usuarios no solo incrementa los efectos positivos en la misma escala, sino que aquellos impactos negativos pueden verse multiplicados de forma exponencial. Por ejemplo, la reducción por parte de los usuarios de FFCS en su uso del transporte público y el impacto que este hecho tiene en la congestión del tráfico, podría no seguir una regla de proporcionalidad lineal.

Debido a la imposibilidad de esta transferencia de resultados, la comunidad científica ha trabajado, desde que Car2go implantó el primer sistema FFCS en 2008 en Ulm, para determinar los impactos concretos de estos sistemas (Firnkorn y Müller, 2011b). Sin embargo, dada su corta experiencia al ser servicios muy recientes y las peculiaridades de cada sistema y entorno urbano en el que se implanta, es necesario desarrollar más metodologías de análisis científico para poder sacar conclusiones concretas.

Como el FFCS nació en Alemania, los primeros estudios centrados en evaluar su impacto se concentraron allí. La metodología empleada mayoritariamente fue la realización de encuestas a usuarios, en algunas ocasiones, complementadas con simulaciones matemáticas para analizar situaciones hipotéticas. Inicialmente, las investigaciones se centraron en el estudio de la sostenibilidad de este nuevo modo de transporte, como las desarrolladas en la pequeña ciudad de Ulm (Firnkorn y Müller, 2011a; 2011b; Firnkorn, 2012). Los autores se apoyaron en una encuesta a usuarios del sistema de Car2go, que utilizaba vehículos de combustión interna, para hacer una 


\section{ANÁLISIS DEL IMPACTO DE LOS SISTEMAS DE FREE-FLOATING CARSHARING EN ENTORNOS URBANOS UTILIZANDO DATOS WEB: APLICACIÓN A LA CIUDAD DE MADRID}

previsión de sus efectos a cinco años vista. Los principales resultados fueron la reducción de las emisiones de $\mathrm{CO}_{2}$ y que más de un cuarto de los encuestados se plantearía no efectuar la compra de un nuevo vehículo, siempre que el servicio permaneciera disponible en la ciudad. Posteriormente, Firnkorn (2012) validó los resultados anteriores a través de una triangulación usando datos retrospectivos. Ciari, Bock y Balmer (2014) programaron una simulación basada en agentes para comparar las demandas de una flota FFCS y una flota station-based en Berlín, ambas compuestas de vehículos de gasolina, con el fin de analizar cómo afectarían estos nuevos sistemas a los ya existentes. Descubrieron una aparente complementariedad de ambos, además del potencial de la ciudad para que se extendiera su uso. Otros autores también compararon el funcionamiento de ambos tipos de sistemas para caracterizar los patrones de utilización de cada uno, como Becker, Ciari y Axhausen (2017) en Basilea o Wielinski, Trepanier y Morency (2015) en Montreal. En este último caso, además de encuestas, los autores utilizaron datos de los movimientos de los vehículos, suministrados por la empresa operadora del servicio.

Poco a poco, el estado del arte acerca del FFCS evolucionó hacia el análisis de sus problemas operacionales. La ya citada investigación de Herrmann, Schulte y Voß (2014) se apoyó en una campaña de encuestas a usuarios en la ciudad de Hamburgo para estudiar diferentes tipos de incentivos económicos para aquellos usuarios que colaboraran en la reubicación de vehículos. Este tipo de estrategias se efectúan con el objetivo de mejorar la calidad del servicio, sin necesidad de aumentar el tamaño de la flota existente. Sin embargo, el hecho de que los operarios de la compañía redistribuyan los coches hacia las zonas de mayor demanda tiene un coste elevado para el operador y las distancias recorridas en estos procesos deberían ser consideradas en los análisis coste-beneficio y de sostenibilidad de los sistemas de carsharing. EI FFCS ofrece más oportunidades para que sean los usuarios quienes colaboren en esta labor (por ejemplo, notificando en la aplicación cuál es el destino de su viaje, para que el sistema proponga ubicaciones específicas u otros usuarios se unan al viaje). El estudio señaló que los encuestados aceptarían este tipo de estrategias y que la demanda de FFCS está influenciada por la disposición de los usuarios a caminar hacia un coche FFCS para alquilarlo o a esperar hasta que haya un coche disponible cercano a su ubicación (Herrmann, Schulte y Voß, 2014). Una campaña de encuestas similar a esta fue llevada a cabo con estudiantes universitarios en la etapa inicial de esta tesis, mostrando la importancia de la tolerancia de los posibles usuarios a caminar hasta un vehículo disponible. Por otro lado, Ciari, Balac y Balmer (2015) estudiaron, utilizando Zurich como escenario, las implicaciones que tendría sobre el FFCS una regulación de aparcamiento con diferentes estructuras tarifarias.

Otras investigaciones analizaron el FFCS como producto de consumo, apoyándose en encuestas a los usuarios y buscando analizar su actitud hacia la propiedad de vehículos después de haber probado el servicio y, particularmente, su disposición a 
abortar la compra de un vehículo en el futuro (Martin y Shaheen, 2016; Namazu y Dowlatabadi, 2018; Wang et al., 2017). No obstante, los usuarios de FFCS que venden su vehículo propio o renuncian a la compra de un vehículo, podrían tener otras motivaciones más allá de haber experimentado la utilización del FFCS como, por ejemplo, un cambio en los hábitos de movilidad por un cambio de trabajo, un incremento en los costes de mantenimiento del vehículo y del seguro, o unos elevados costes de reparación de una avería cuando el coche es antiguo (Sprei, 2018; Katzev, 2003). Las actitudes hacia la posesión de vehículo son complejas de analizar, aunque sabemos que los usuarios de carsharing tienden a tener menor sentido de la propiedad y una visión más utilitaria de la movilidad (Bardhi y Eckhardt, 2012; Lamberton y Rose, 2012; Prettenthaler y Steininger, 1999). Evaluar el impacto del FFCS en la posesión, también implica analizar las desventajas que implica el tener un coche propio, como los costes de mantenimiento, reparación y seguros o el disponer de aparcamiento. Además, las regulaciones de aparcamiento en el viario público dependen de cada Ayuntamiento y esta es otra de las razones por las que la transferencia de resultados de un país a otro, o incluso de una ciudad a otra, debe hacerse con cautela.

La comunidad científica fue dándose cuenta de los problemas que plantea el uso de encuestas para definir los efectos del FFCS debido a la dificultad para obtener una muestra representativa. De acuerdo con Müller, Correia y Bogenberger (2017), no se puede garantizar que la muestra mantenga las mismas proporciones que los grupos de usuarios y, por tanto, su volumen de viajes. Por esta razón, las encuestas deben usarse junto a otras metodologías y, con el paso de los años, han pasado de emplearse como base de simulaciones matemáticas a servir de información complementaria a los resultados obtenidos del análisis de datos reales, como señalan Ciociola et al. (2017).

Hasta el momento, el análisis de flujos de viajes reales de FFCS escasea en la literatura debido a las dificultades para obtener datos directamente de las compañías operadoras de estos sistemas. Solo unos pocos investigadores se han podido beneficiar de este tipo de información (Schmöller et al., 2015; Müller, Correia y Bogenberger, 2017). En el caso del estudio desarrollado por Schmöller et al. (2015), DriveNow y Car2go proporcionaron datos de alquiler de vehículos en Munich y Berlín durante dos años e información de los usuarios registrados. Con ellos, los autores describieron la utilización del FFCS e identificaron espacialmente los factores socioeconómicos que influyen en su demanda. Posteriormente, Müller, Correia y Bogenberger (2017), utilizando datos de alquileres en Berlín suministrados por DriveNow, diseñaron un modelo binominal negativo para analizar la influencia del uso del suelo y los datos censales en la demanda de FFCS. El modelo fue validado en las ciudades de Munich y Colonia, obteniendo resultados satisfactorios. Los principales resultados se centraron en condicionantes como la ubicación de una zona, el aparcamiento o las características de sus habitantes, concluyendo que cuanto más 


\section{ANÁLISIS DEL IMPACTO DE LOS SISTEMAS DE FREE-FLOATING CARSHARING EN ENTORNOS URBANOS UTILIZANDO DATOS WEB: APLICACIÓN A LA CIUDAD DE MADRID}

céntrico es un barrio, mayor disponibilidad de aparcamiento hay y las personas que allí viven tienen más predisposición a utilizar TICs, habrá un mayor volumen de alquileres de FFCS.

Debido a las dificultades para obtener registros de viajes reales proporcionados por los operadores, algunos autores han optado por herramientas alternativas como la adquisición de los datos de las API de los operadores (Habibi et al., 2017; Ciociola et al., 2017). Una API, que corresponde a las siglas del término en inglés Application Programming Interface, es la interfaz donde los usuarios consultan información en tiempo real de la distribución de los coches disponibles en un área. Cada vehículo tiene una identificación y se muestra información acerca de su nivel de batería o combustible, lo que puede ser usado para reconstruir viajes e incluso hacer distinciones entre viajes reales y aquellas reservas que finalmente no se traducen en viajes. Desde un punto de vista metodológico, Müller, Correia y Bogenberger (2017) señalaron una cuestión importante acerca de la utilización de flujos reales a través del acceso a las interfaces que proporcionan información en tiempo real de los sistemas de FFCS: el proceso de reconstrucción de viajes no es automático ni, mucho menos, fácil, como se puede suponer a priori. Los datos se deben tratar con precaución y se deben crear mecanismos para identificar flujos reales basados en hipótesis científicas. Por ejemplo, la no disponibilidad de un vehículo en la aplicación puede deberse al viaje de un usuario, pero también a labores de recarga o mantenimiento o a alguna avería en el sistema de comunicaciones de ese vehículo. A este problema se le une que la interpretación de los datos adquiridos es más compleja en una ciudad donde hay varias empresas de FFCS que suministran servicios con diferentes características (diferentes áreas de servicio, diferentes estructuras tarifarias, etc.). No obstante, hasta el momento, este procedimiento representa la mejor alternativa frente a la utilización de datos reales de las operadoras.

En su investigación, Habibi et al. (2017) recogieron datos públicos de la disponibilidad de vehículos en las páginas web de tres operadores entre 2014 y 2016, lo que permitió la identificación de 27 millones de movimientos en 22 ciudades europeas y norteamericanas. Con ello, compararon los patrones de utilización del FFCS en dichas ciudades: longitud media de los viajes, tasas de utilización y distribución de los viajes a lo largo del día. Por lo general, se observaron mayores distancias recorridas por viaje en las ciudades estadounidenses, mientras que Madrid y Hamburgo son las que presentaron mayores tasas de utilización, entendiéndose esa tasa como el tiempo que el vehículo está ocupado (o número de viajes al día por duración media de un viaje). En cuanto a la distribución horaria de los viajes, la mayoría de las ciudades mostraron patrones similares, con una punta de viajes por la mañana y otro pico mayor por la tarde, perfil que sigue el de otros modos de transporte. Madrid es una de las ciudades que presenta algunas diferencias específicas, con un pico adicional a la hora de comer. Por su parte, Ciociola et al. (2017) diseñaron una plataforma con la que adquirieron datos FFCS de dos operadores (Car2go y Enjoy) durante 52 días en Turín. 
Aunque dichos datos permitieron un buen análisis a nivel temporal y espacial, los autores reconocieron que se necesita cierto "ingenio" para limpiar la base de datos y resolver cuestiones como los problemas en la adquisición debidos al diseño de la plataforma, fallos en la página web del operador, identificación de viajes de recarga o mantenimiento, errores de determinación de la ubicación GPS de los vehículos, etc. Una de las contribuciones más destacadas de esta investigación, además del análisis espacial, es la comparación del tiempo de viaje en FFCS y su equivalente utilizando transporte público. Se muestra que, de media, los viajes en FFCS en la ciudad italiana duran un $36 \%$ menos que en transporte público y que la preferencia por el FFCS se produce cuando el tiempo en transporte público es, al menos, 10 minutos superior. Este análisis, por ejemplo, sería imposible de realizar utilizando solo encuestas y muestra la importancia de determinar viajes con datos publicados en las aplicaciones o páginas web, sobre todo cuando los datos oficiales no están disponibles.

\section{II.4. MADRID COMO CASO DE ESTUDIO}

La contaminación del aire es una de las mayores preocupaciones en las principales áreas urbanas del planeta (Organización Mundial de la Salud, 2014) y Madrid no es una excepción, pues supera los límites de calidad del aire marcados por la Directiva 2008/50/EC (Ayuntamiento de Madrid, 2016a), aunque es cierto que las iniciativas promovidas en los últimos años están teniendo un efecto positivo. Por ejemplo, si en 2016 en nueve de las 24 estaciones de medición de la calidad del aire de la ciudad se superó el límite anual legal de dióxido de nitrógeno establecido en $40 \mu \mathrm{g} \cdot \mathrm{m}^{-3}$, en 2018 fueron siete y en 2019 tan solo dos (Ayuntamiento de Madrid, 2019). El Ayuntamiento de Madrid lleva promoviendo políticas de bajas emisiones en la regulación de aparcamiento en el viario público desde hace años (Ayuntamiento de Madrid, 2005; Ayuntamiento de Madrid, 2016b). La zona de estacionamiento regulado, conocida como zona SER, se limitó a la superficie que prácticamente se corresponde con la Almendra Central, limitada por la M-30 y en cuyo interior se encuentran los distritos más céntricos. Esta ordenanza permite el estacionamiento de vehículos durante un tiempo limitado y a cambio del pago de una tarifa por minuto que puede contar con deducciones en función de la antigüedad del vehículo. Además, existen exenciones para los residentes en cada zona o para vehículos con motores eléctricos o híbridos.

En 2018, las políticas en materia de movilidad del Ayuntamiento dieron un paso más en la intención de mejorar de la calidad del aire de la ciudad con la creación de las Zonas de Bajas Emisiones (ZBE) (Ayuntamiento de Madrid, 2018), persiguiendo los objetivos de reducción de los niveles de contaminación ambiental y mejora de la calidad de vida de sus residentes; promoción de una movilidad más sostenible, favoreciendo el transporte público colectivo y los medios y vehículos menos contaminantes; y disminución de la intensidad de tráfico, recuperando espacio público para el peatón. La primera ZBE, y única hasta la fecha, ha sido la conocida como 
Madrid Central, que comprende los barrios del distrito Centro. Con el cambio de color político en el consistorio tras las elecciones municipales, se intentó derogar esta regulación, pero no lo logró por la presión de organismos como la Unión Europea que consideraron que Madrid no podía dar marcha atrás en este aspecto tan trascendental. En las ZBE, está permitido el acceso, circulación y aparcamiento de vehículos eléctricos e híbridos y no se permiten estas acciones a vehículos de combustión interna excepto bajo circunstancias específicas. Debido a su reciente constitución, el impacto de esta política apenas ha sido evaluado en la literatura (Ahmed, 2019) y mucho menos su impacto en el FFCS, aunque todo parece indicar que esté favoreciendo la operación de estos sistemas, pues todos los de la ciudad están formados por flotas totalmente eléctricas o híbridas.

Actualmente, en la ciudad operan cuatro compañías de sistemas de FFCS y numerosas que utilizan el mismo esquema de negocio, pero utilizan otros tipos de vehículos: motocicletas, patinetes y bicicletas. Existe incluso un sistema de bicicleta compartida de gestión pública, aunque en este caso está basado en estaciones. También existen otras empresas que ofrecen servicios de carsharing basado en estaciones, como Ubeequo, Respiro o Wishilife. Dada la proliferación de operadoras de estos servicios, especialmente los de motos eléctricas, el Ayuntamiento reguló su funcionamiento en la Ordenanza de Movilidad Sostenible (Ayuntamiento de Madrid, 2018).

El primero en implantar un sistema de coche compartido flotante fue Car2go. Aunque la filial de la alemana Daimler lleva operando este tipo de sistemas desde 2008, no fue hasta noviembre de 2015 cuando llegó a la capital española. Respecto a la situación de 2017 analizada en esta investigación, la compañía ha reducido considerablemente el número de ciudades en las opera, manteniendo aquellas en las que hay mayor rentabilidad. Actualmente, opera en 17 ciudades europeas bajo el nombre de ShareNow, tras haberse fusionado con DriveNow, usando diferentes modelos de Mercedes-Benz, BMW, Mini y Smart. En Madrid empezó con 500 unidades eléctricas (BEV) del modelo biplaza de Smart, pero posteriormente ha incorporado vehículos similares de cuatro plazas. Ambos modelos son compactos, lo que los hace muy apropiados para circular y aparcar en ciudades congestionadas con espacio limitado de aparcamiento. En 2018 la tarifa en Madrid era de $0.21 € / m i n$ pero, actualmente, la compañía alemana ofrece una tarifa dinámica que varía entre 0.19 y $0.31 € / m i n$ en función de la oferta y la demanda de cada zona y en cada momento. A diferencia de otros lugares, los vehículos son cargados solamente por los operarios del servicio y no se ofrece a los usuarios la posibilidad de cargarlos a cambio de descuentos en la tarifa, puesto que en la ciudad la infraestructura de carga pública es reducida.

La segunda compañía en lanzar un sistema FFCS en Madrid fue Emov, una start-up sin experiencia previa formada a partes iguales por el fabricante de automóviles Grupo PSA y la empresa de gestión de aparcamiento Eysa, aunque posteriormente la primera adquirió todas las participaciones. En diciembre de 2016, Emov desplegó una 
flota de 600 unidades del vehículo eléctrico Citroen C-Zero (BEV) y, recientemente, está incorporando vehículos de otros modelos también eléctricos. En 2018 su tarifa era de $0.24 € / \mathrm{min}$, aunque ahora tienen tarifas que oscilan entre los 0.25 y $0.29 € / \mathrm{min}$, dependiendo de la franja horaria en la que se produzca el alquiler.

Un año más tarde, en diciembre de 2017, aterrizó la tercera operadora en la ciudad, Zity, impulsada por Ferrovial en colaboración con Renault. En la actualidad, gestionan una flota de 725 vehículos eléctricos del modelo Renault Zoe (BEV) y el área de servicio más amplia, abarcando otros municipios del área metropolitana. También tienen una tarifa variable entre 0.21 y $0.31 € / \mathrm{min}$, aunque permiten a sus usuarios mantener la reserva del coche mientras está aparcado con una tarifa reducida (0.06 $0.12 € / \mathrm{min}$ ). En junio de 2018 , otro fabricante de automóviles, Kia, y la compañía energética Repsol lanzaron Wible, el primer sistema FFCS que utiliza vehículos híbridos (PHEV), los cuales también pueden aparcar gratis y sin limitación temporal en las zonas de estacionamiento regulado de la ciudad. En este caso, disponen de 600 Kia Niro, un vehículo con mayores dimensiones, y una tarifa que oscila entre 0.28 y $0.31 € / \mathrm{min}$.

La evolución de los tipos de servicios existentes en Madrid no ofrece un escenario en el que se pueda hacer un análisis comparativo agregado. Esta investigación se centra en los inicios del FFCS en la ciudad, contando con registros de viajes de los dos primeros operadores, Car2go y Emov, cuando llevaban implantados dos y un año, respectivamente. Posteriormente, la irrupción de otros sistemas con áreas de servicio más extensas, zonas de aparcamiento reservadas o que ofrecen nuevas características como mantener la reserva a un precio más reducido mientras el coche está aparcado, hacen que el estudio de los flujos Origen-Destino sea más complejo. Además, la estructura tarifaria de todas las compañías ha evolucionado a una tarifa dinámica que cambia de precio en función del momento del día, lo que impide hacer un análisis de la distribución de viajes a lo largo del día que no esté sesgado. Por otro lado, la introducción de vehículos híbridos impide cualquier análisis acerca de los beneficios medioambientales que pueden generar en la ciudad, puesto que con los datos adquiridos de la web no dispondríamos de las proporciones recorridas usando motor de gasolina y motor eléctrico. Afortunadamente, cuando se adquirieron los datos para esta investigación, tanto Car2go como Emov, ambos con flotas totalmente eléctricas, aún tenían tarifas fijas por minuto ( 0.21 y $0.24 € / m i n$, respectivamente) y áreas de servicio coincidentes, aunque en el caso del segundo operador, de mayor extensión (Figura 3). 


\section{ANÁLISIS DEL IMPACTO DE LOS SISTEMAS DE FREE-FLOATING CARSHARING EN ENTORNOS URBANOS UTILIZANDO DATOS WEB: APLICACIÓN A LA CIUDAD DE MADRID}

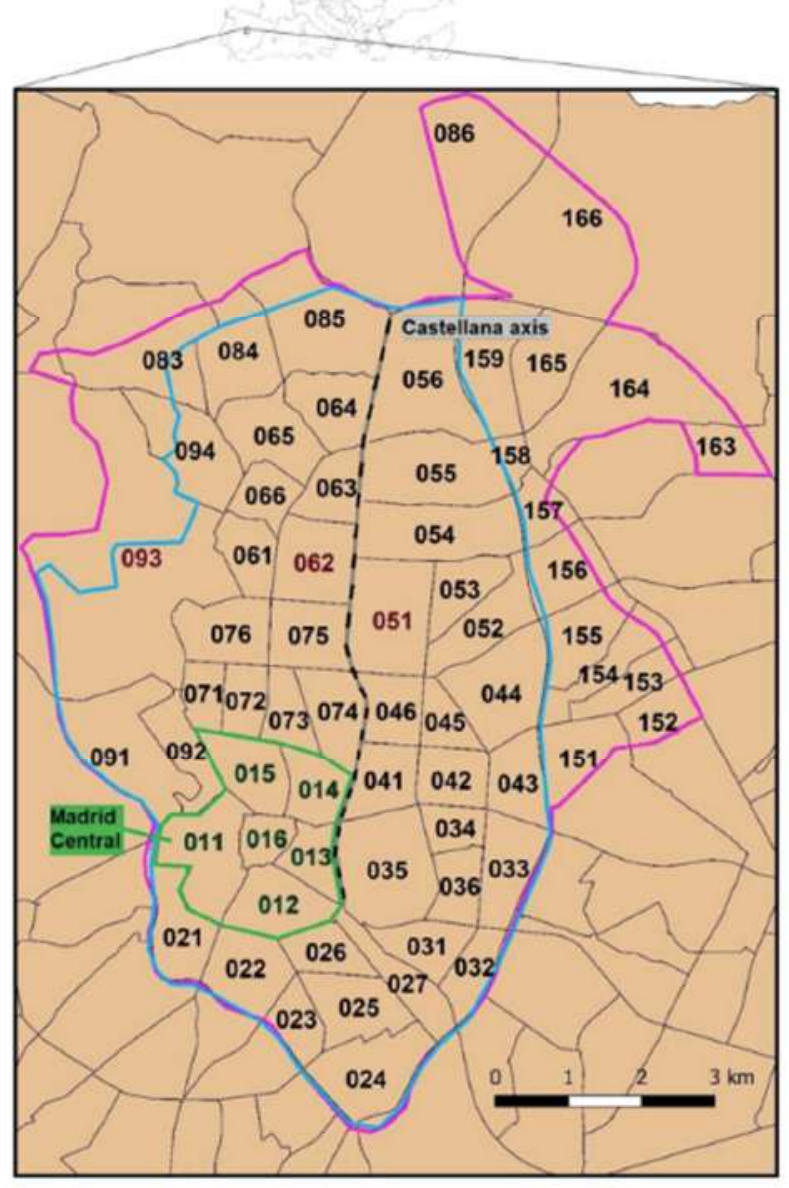

\begin{tabular}{|c|c|}
\hline 011 Palacio & 062 Cuatro Caminos \\
\hline 012 Embajadores & 063 Castillejos \\
\hline 013 Cortes & 064 Almenara \\
\hline 014 Justicia & 065 Valdeacederas \\
\hline 015 Universidad & 066 Bernuguete \\
\hline 016 Sol & 071 Gaztambide \\
\hline 021 Imperial & 072 Arapiles \\
\hline 022 Las Acacias & 073 Trafalgar \\
\hline 023 La Chopera & 074 Almagro \\
\hline 024 Legazpi & 075 Rios Rosas \\
\hline 025 Delicias & 076 Vallehermoso \\
\hline 026 Palos de Moguer & Q83 Peña Grande \\
\hline 027 Atocha & 084 El Pilar \\
\hline 031 Pacífico & 085 La Paz \\
\hline 032 Adelfas & 086 Valverde \\
\hline 033 Estrella & 091 Casa de Campo \\
\hline 034 lbiza & 092 Argüelles \\
\hline 035 Jerónimos & 093 Ciudad Universitaria \\
\hline 036 Niño Jesús & 094 Valdezana \\
\hline 041 Recoletos & 151 Ventas \\
\hline 042 Goya & 152 Pueblo Nuevo \\
\hline 043 Fuente del Berro & 153 Quintana \\
\hline 044 Guindalera & 154 Concepción \\
\hline 045 Lista & 155 San Pascual \\
\hline 046 Castellana & 156 San Juan Bautista \\
\hline OS1 El Viso & 157 Colina \\
\hline 052 Prosperidad & 158 Atalaya \\
\hline 053 Ciudad Jardin & 159 Costillares \\
\hline 054 Hispanoamérica & 163 Canillas \\
\hline 0S5 Nueva España & 164 Pinar del Rey \\
\hline 056 Castilla & 165 Apóstol Santiago \\
\hline 061 Bellas Vistas & 166 Valdefuentes \\
\hline
\end{tabular}

Car2go service area

Emov service area

Figura 3. Zonas de servicio de los sistemas FFCS en el momento de la adquisición de datos. Se señalan los barrios situados en su interior, de acuerdo con la numeración de los distritos en los que se encuentran. 


\section{BLOQUE III. METODOLOGÍA DE LA INVESTIGACIÓN}

\section{III.1. FASES DE LA INVESTIGACIÓN}

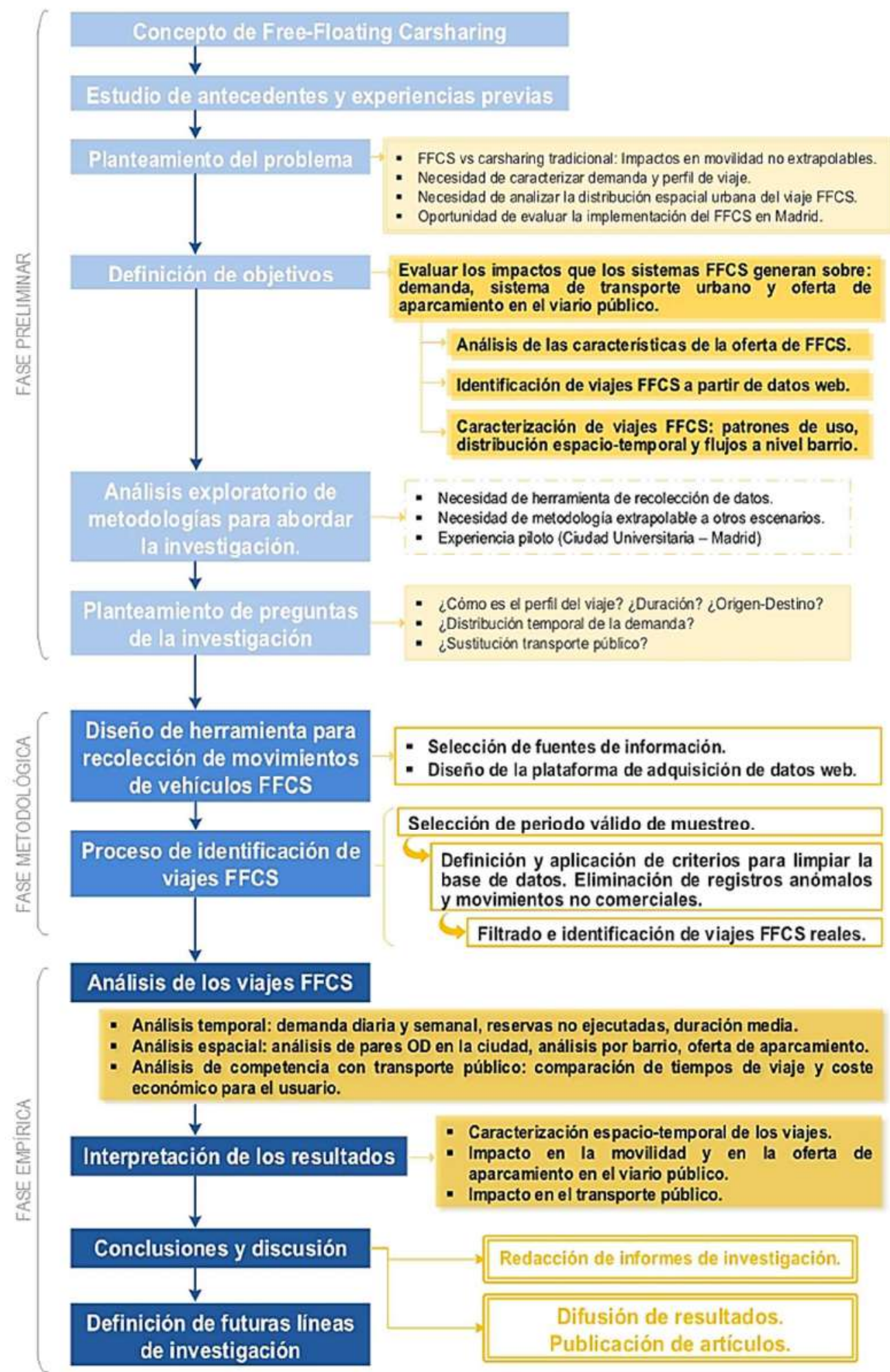

Figura 4. Fases de la investigación. 
La metodología empleada en esta investigación ha evolucionado en función de los medios disponibles en cada momento y los resultados obtenidos en las pruebas piloto implementadas en la ciudad de Madrid.

Después de llevar a cabo un análisis de los antecedentes y experiencias previas desarrolladas en otros países para analizar los sistemas de FFCS, se definió la problemática a resolver y los objetivos a alcanzar en la tesis doctoral. En esta fase preliminar también se tantearon diversas metodologías para abordar la investigación. La experiencia piloto inicial consistió en el análisis del impacto del Free-Floating Carsharing en una zona concreta de Madrid (Ciudad Universitaria) a partir de una campaña de encuestas a estudiantes y de la toma de imágenes periódica de la página web del operador Car2go. Las observaciones fueron tomadas durante un periodo de tiempo muy limitado y cada 30 minutos, lo que supone una frecuencia excesiva. Además, estas imágenes solo permitieron evaluar la disponibilidad, pero no conocer en detalle las características de los viajes. Estaba limitada a un único operador, una zona específica de la ciudad y a un grupo de población concreto: los estudiantes universitarios. Los trabajos desarrollados en esta fase preliminar se publicaron en un primer artículo científico (Ampudia-Renuncio, Guirao y Molina-Sánchez, 2018).

Tras la fase preliminar, se decidió diseñar una plataforma con el fin de adquirir en tiempo real los datos disponibles en las páginas web de dos operadores que existían en ese momento en Madrid (Car2go y Emov). A través de plataforma, se obtuvieron más de cuatro meses de registros en toda la ciudad, datos que fueron sometidos a un proceso de limpieza y análisis a partir de hipótesis basadas en la operación real de estos sistemas. De este modo, se llevó a cabo un proceso de identificación de los viajes reales en vehículo FFCS que se produjeron en el periodo considerado. Finalmente, se llevó a cabo el análisis del conjunto de datos y la interpretación de los resultados obtenidos, expuesto en el bloque $\mathrm{V}$ de este documento.

Un primer análisis de los datos web se publicó en un segundo artículo (AmpudiaRenuncio et al., 2020a). El análisis por barrios, con los orígenes y destinos más frecuentes, se publicó en un tercer artículo (Ampudia-Renuncio et al., 2020b).

\section{III.2. TRABAJOS PRELIMINARES EN UN BARRIO DE LA CIUDAD}

La campaña de encuestas se realizó en noviembre de 2016 en la Escuela Técnica Superior de Ingenieros de Caminos, Canales y Puertos de la Universidad Politécnica de Madrid (ESTICCP), situada en el campus de Ciudad Universitaria ubicado en el barrio que lleva el mismo nombre (barrio 093 de la figura 3). Los cuestionarios se distribuyeron entre alumnos de Máster, tanto de turno de mañana como de tarde, y se obtuvo una muestra de 186 respuestas válidas. Con el fin de determinar las distancias a los coches FFCS disponibles, se consideró la puerta principal de la ETSICCP como origen y destino de los viajes. 
La elección de la población de estudiantes universitarios no fue casual. La literatura ha demostrado que los millennials, generación a la que pertenece la muestra de la encuesta, tienen gran potencial para fidelizarse con estos sistemas. Estudios realizados en los últimos años han revelado que los millennials tienden a poseer o comprar menos coches y a usar más servicios de economía colaborativa (Dempsey, 2016; Delbosc, 2017; Hwang y Griffiths, 2017). El carsharing en entornos universitarios ha sido analizado ampliamente en Estados Unidos, especialmente con sistemas round-trip (Stocker et al., 2016). Los resultados de este artículo mostraron que, al menos, un $5 \%$ de los miembros de la comunidad universitaria habían vendido su coche o habían pospuesto la compra debido al uso del sistema de carsharing. Sin embargo, estas conclusiones no pueden ser extrapoladas a los campus universitarios españoles debido a su diferente estructura, generalmente más integrados en la ciudad, y a las diferencias entre los sistemas de carsharing tradicional y el FFCS, expuestas en capítulos anteriores.

El tamaño muestral escogido cumple con un nivel de confianza del $95 \%$ y un margen de error del $10 \%$, teniendo en cuenta que la población total estimada en el Campus de Ciudad Universitaria es de aproximadamente 80.000 estudiantes. En dicho campus se encuentran gran parte de los centros universitarios de la Universidad Politécnica de Madrid (UPM) y la Universidad Complutense de Madrid (UCM). En el curso académico en el que se llevó a cabo la campaña de encuestas (2016-2017), el total de alumnos que estudiaba en las Escuelas Técnicas Superiores y otros centros de la UPM ubicados en el campus fue de 24.815. En cuanto a la UCM, no se ha encontrado un detalle de estudiantes por centro universitario, pero sí el total de estudiantes en 20162017 que fue de 74.292. Considerando que en el campus se ubican 19 de las 26 Facultades de la UCM, mediante una relación de proporcionalidad lineal, podemos establecer que había alrededor de 55.000 estudiantes.

En cuanto al centro universitario seleccionado para la realización de la campaña de encuestas (ETSICCP), es el lugar donde se imparte una titulación de carácter experimental. Por tanto, se considera que sus estudiantes tendrían una alta movilidad en comparación a estudiantes de otras titulaciones y la probabilidad de encontrar en la muestra usuarios de FFCS sería mayor.

La intención fue recoger a través de un cuestionario ( 


\section{ANÁLISIS DEL IMPACTO DE LOS SISTEMAS DE FREE-FLOATING CARSHARING EN ENTORNOS URBANOS UTILIZANDO DATOS WEB: APLICACIÓN A LA CIUDAD DE MADRID}

Tabla 1) la percepción de los estudiantes acerca de los sistemas de FFCS, cuando la operadora Car2go llevaba un año en la ciudad, en función de su experiencia como usuarios del servicio o no. También se les preguntó acerca de su elección modal habitual en los viajes al campus y su disposición a caminar hacia un vehículo FFCS disponible. La literatura ha demostrado que la frecuencia es el principal atributo de la calidad del servicio del transporte público y en el caso del carsharing, su equivalente sería la disponibilidad de vehículos a una distancia limitada desde el punto de origen del viaje. La limitación de la distancia es una cuestión clave al analizar los patrones de uso de los sistemas FFCS. Otros aspectos que se estudiaron fueron cuánto tiempo estaría dispuesto a esperar el potencial usuario si no hubiera un vehículo disponible dentro del radio deseado y, en el caso de no aparecer ninguno en ese tiempo, qué modo de transporte utilizaría.

Además de estas cuestiones, también se abordó la hipotética actitud de los encuestados si les ofrecieran incentivos económicos (minutos gratis para usar el servicio o un descuento de la tarifa en el viaje actual) a cambio de la colaboración para facilitar la recolocación de los vehículos. Generalmente, estas estrategias son llevadas a cabo internamente por los operadores con el fin de garantizar una adecuada disponibilidad del servicio a sus usuarios, pero contar con la colaboración de estos, podría suponer una reducción considerable de los gastos de operación.

La disponibilidad de vehículos FFCS en una zona determinada depende de la disponibilidad de aparcamiento. En ese aspecto, Ciudad Universitaria es una excepción dentro de la Almendra Central de Madrid, puesto que la mayoría del aparcamiento en el viario público no cuenta con regulación de zona SER. Además, cuenta con grandes aparcamientos junto a algunas de las Facultades o Escuelas que hay en el campus, pero no están repartidos de forma homogénea. En la ETSICCP existe un gran aparcamiento frente a la fachada principal, aunque también es posible aparcar en otras áreas y en el viario público cercano. También hay zonas de aparcamiento reservadas para el personal docente e investigador, que no se han tenido en cuenta en este estudio, puesto que normalmente tienen limitaciones de entrada y las compañías de FFCS no permiten terminar el viaje en zonas que no sean accesibles para el siguiente usuario.

La metodología para la captación de datos de movilidad de FFCS se basó en el registro de la evolución de la disponibilidad de coches de Car2go en el campus durante una semana a través de la captura programada de imágenes de la web del operador. Se registraron observaciones cada 30 minutos desde las 0:00 h del lunes 3 de octubre de 2016 a las 0:00 h del lunes 10 de octubre de 2016, haciendo un total de 337 observaciones en toda la semana. Se escogió una semana de octubre con clases regulares y sin eventos especiales y tampoco se registró meteorología anómala para la época del año. 
Tabla 1. Estructura del cuestionario de la encuesta.

Pregunta

Domicilio del estudiante en Madrid

¿El domicilio se encuentra dentro de la M-30?

Experiencia como usuario de Cargo

¿Disponibilidad de vehículo privado para los viajes a la Escuela?

Hora de inicio de las clases (hora estimada de llegada a la Escuela)

Hora de finalización de las clases (hora estimada de salida de la Escuela)

Asistencia a las bibliotecas del campus en sábado

Modo de transporte usado para ir y volver de la Escuela

Máxima distancia por andar para llegar a un vehículo FFCS disponible

Máximo tiempo de espera si no hay ningún vehículo disponible en ese momento

Modo de transporte alternativo cuando se supera el tiempo de espera máximo

¿Disposición a reservar un vehículo más distante a cambio de un $30 \%$ de descuento de la tarifa del viaje?

¿Disposición a indicar el destino del viaje al principio del viaje?

Tipo de incentivo preferido
Opciones de respuesta

Código Postal

Sí/No

Sí/No

Sí/No

Respuesta abierta

Respuesta abierta

Sí, normalmente / No, nunca / Sí, a veces

Transporte público / Vehículo propio / Otros (especificar)

Menos de 300 m / 500 m o menos / No me importa andar más de $500 \mathrm{~m}$

30 minutos o más / Menos de $30 \mathrm{~min} /$ Menos de $15 \mathrm{~min}$

Transporte público / Vehículo propio / Otros (especificar)

Sí / No / No, debería ser un descuento mayor

Sí / No

Minutos gratis / $30 \%$ de descuento en la tarifa

\section{III.3. FUENTES DE INFORMACIÓN}

Después de la fase preliminar, la intención fue extender la zona de estudio a toda la ciudad y encaminar la investigación hacia el análisis de flujos reales, metodología que apenas se había utilizado hasta ese momento para evaluar los efectos del FFCS debido a la complejidad de la obtención de los datos, pero que aporta una información muy valiosa. Dado que fue imposible que los operadores proporcionaran registros de 
viajes, se optó por desarrollar una plataforma que captase la información de la disponibilidad de los vehículos publicada por los operadores de FFCS.

Las principales fuentes de información en esta segunda fase fueron las páginas web de los dos operadores de FFCS que existían en ese momento en la ciudad de Madrid: Car2go y Emov. Tanto las webs como las aplicaciones móviles desarrolladas son una herramienta indispensable para el funcionamiento de estos sistemas, puesto que a través de ellas se informa a los usuarios de la disponibilidad de los vehículos, indicando su identificación, posición y estado de la batería o del depósito.

Con el fin de obtener una base de datos precisa, es importante conocer cómo funcionan los sistemas FFCS y cuáles son las peculiaridades de los operadores a estudiar, antes de proceder al diseño de la plataforma de adquisición de datos. Una vez los datos se han registrado, su interpretación y análisis también requieren un conocimiento exhaustivo de los procesos de reserva, alquiler y recarga de los vehículos. Como se ha señalado en el estado del arte, el proceso de reconstrucción de viajes no es automático y se deben diseñar unas reglas y algoritmos para identificar viajes que estén basados en hipótesis científicas (Müller, Correia y Bogenberger, 2017). Es necesario llevar a cabo un proceso de limpieza de la base de datos con el fin de llegar a una correcta interpretación de los resultados.

Por otro lado, otras fuentes de información adicional consultadas fueron los calendarios oficiales de la Ciudad de Madrid de los años 2017 y 2018 y la información registrada por la Agencia Estatal de Meteorología durante el periodo de tiempo analizado. Gracias a ellas, posteriormente se pudieron identificar los periodos de tiempo con un comportamiento particular, especialmente los días festivos o los periodos de vacaciones con el fin de no incluirlos en los análisis de viajes por tipo de día de la semana.

\section{III.4. DISEÑO DE LA PLATAFORMA DE ADQUISICIÓN}

Como parte de la metodología de esta investigación, se diseñó una plataforma llamada CarTrack para adquirir datos de vehículos FFCS mediante "escucha pasiva". Es decir, su propósito fue recopilar metadatos públicos proporcionados por las empresas cuando los usuarios consultan la interfaz durante el proceso de alquiler de vehículos a través de la aplicación. Esta plataforma fue programada para recoger y almacenar datos en tiempo real de las páginas web de Car2go y Emov en Madrid, aunque podría ser utilizada en otras localizaciones y adaptada para otros fines. Hay que tener en cuenta que las webs no transmiten ninguna información de los vehículos cuando no están disponibles, ya sea por reservas o viajes de usuarios o porque se están realizando labores de recarga de la batería o de mantenimiento, por lo que solo se recogieron datos de identificación, posición y estado de la batería cuando los vehículos estaban disponibles. 
La plataforma se programó para crear un registro cada vez que un coche desaparecía de la interfaz, el cual finalizaba una vez el coche volvía a aparecer. Este registro generalmente equivale a un viaje, aunque hay que tener en cuenta que comienza cuando un usuario reserva un coche y termina cuando cierra el coche tras finalizar el viaje. Para reservar un viaje desde la aplicación, el usuario selecciona el coche que le interesa, en función de su ubicación y el estado de su batería, y a partir de ese momento el coche deja de estar disponible, por lo que el registro incluye el tiempo de reserva antes de iniciar el viaje. Por otro lado, el coche vuelve a aparecer en la interfaz cuando el usuario finaliza el viaje y cierra el coche, siempre que el nivel de batería esté por encima del mínimo requerido. En caso contrario, el coche sería llevado a recargar la batería y durante este tiempo seguiría figurando como no disponible.

Se recabaron los metadatos (latitud, longitud, nivel de batería e identificación) de todos los coches disponibles cada 30 segundos y con los registros generados se fue alimentando una plataforma Big Data. La elección de la cadencia en la captura de información se hizo porque, al analizar el número de identificaciones positivas de vehículos disponibles con relación a la tasa de consultas de la plataforma, se observó que la identificación positiva aumentaba al alcanzar la tasa de muestreo de 30 segundos. Por debajo de este valor, el número de vehículos identificados disminuía debido a limitaciones relacionadas con los recursos computacionales del sistema desarrollado (el tiempo de adquisición a veces era superior a la frecuencia de muestreo).

Aunque se recabaron datos durante un periodo de tiempo más prolongado, para esta investigación se seleccionó el periodo comprendido entre el 28 de noviembre de 2017 y el 12 de abril de 2018. Durante este tiempo, la plataforma tuvo un funcionamiento adecuado, una vez superada la fase piloto y resueltos los problemas operacionales iniciales. Los datos recopilados se almacenaron en una base de datos Cassandra que ofrece alta disponibilidad y rendimiento. Se registró la localización inicial y final, la distancia recorrida, el nivel de batería inicial y final y el instante inicial y final de cada periodo en el que un coche no estaba disponible. También se determinó el barrio inicial y final del viaje a partir de las localizaciones registradas, con la idea de llevar a cabo un análisis de los flujos origen-destino usando como unidad espacial los barrios en los que se divide la ciudad.

Aunque la plataforma CarTrack proporciona funcionalidades para recopilar y almacenar datos de diferentes operadores de FFCS, el análisis no se pudo llevar a cabo directamente en la plataforma debido a la necesidad previa de realizar una limpieza de la base de datos. 


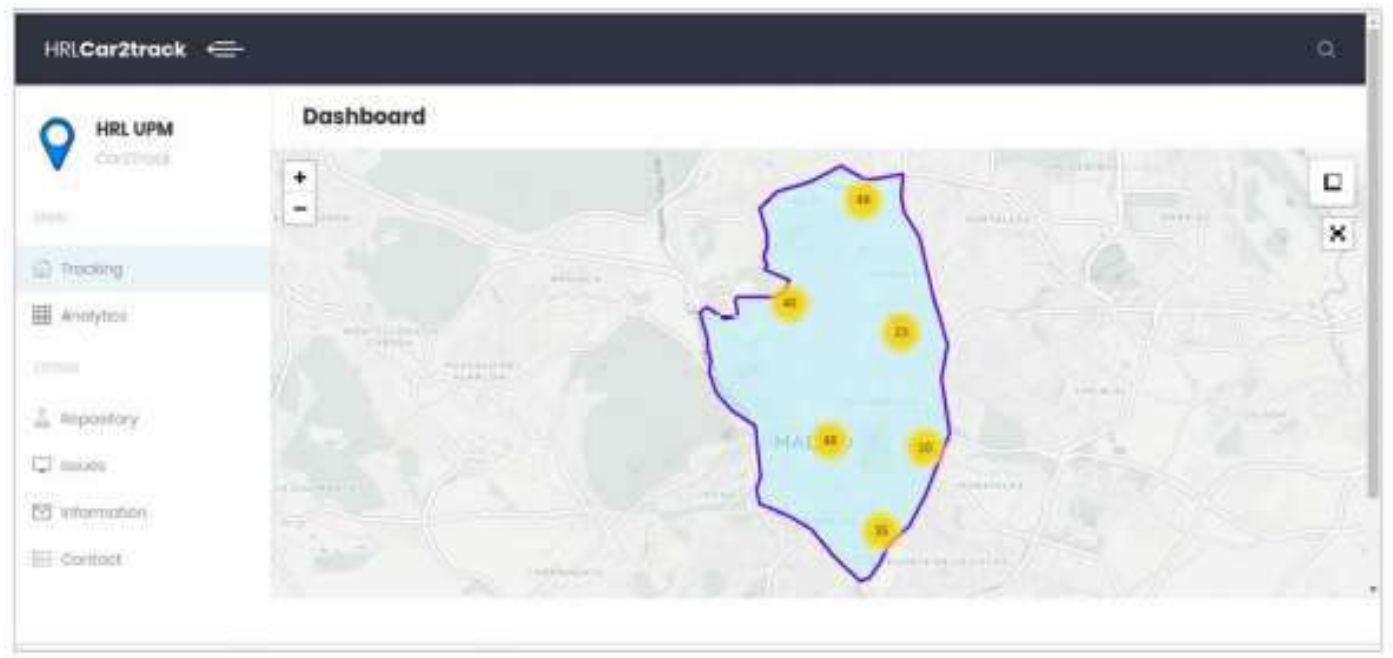

Figura 5. Vista de la interfaz de la plataforma CarTrack.

\section{III.5. IDENTIFICACIÓN DE VIAJES FFCS}

Una vez seleccionado el periodo de tiempo en el que la plataforma de adquisición tuvo un funcionamiento adecuado, se procedió a la extracción de los ficheros para su análisis.

A pesar de que el funcionamiento de la plataforma fue adecuado, durante este periodo se produjeron pequeñas anomalías en la toma de datos. Dichas anomalías pueden producirse bien por fallos en los sistemas del operador que hacen que los vehículos no estén disponibles y, por lo tanto, no aparezcan en la página web y en la aplicación, o bien por fallos en la plataforma de adquisición al perder la ruta debido a actualizaciones de la página web. A lo largo del periodo de tiempo seleccionado, se identificaron incidentes que implicaron que no se pudiera registrar parte o la totalidad de los viajes correspondientes a días concretos. Se decidió extraer por completo de la base de datos aquellos días en los que el número de registros fue anormalmente bajo.

Después de esta primera extracción, se conformó la base de datos con la que se iba a trabajar. Sin embargo, aún era necesario identificar los registros que correspondían a viajes reales. La falta de información acerca de la disponibilidad de un coche en la página web normalmente significa que se está produciendo un viaje, pero puede deberse a otros motivos. Uno de ellos puede ser que un usuario lo haya reservado, o incluso que haya hecho reservas sucesivas, sin llegar a realizar el viaje finalmente. Otras veces puede deberse a operaciones de carga de la batería (o de repostaje), de mantenimiento o de limpieza, o simplemente a problemas de conectividad que hacen que un vehículo esté temporalmente fuera de servicio.

En primer lugar, se procedió a identificar aquellas reservas (bookings) que no se traducían en la realización de un viaje. Para ello, se seleccionaron aquellos registros con inicio y fin en el mismo barrio y cuyo consumo de batería era nulo y se separaron 
del resto de la base de datos. Por lo tanto, el grupo resultante de alquileres (Ilamados rentals) fue el de aquellos registros que cumplían, al menos, una de las siguientes condiciones: empiezan y acaban en barrios distintos o el estado de la batería no es el mismo al final que al inicio.

En segundo lugar, para identificar los viajes realizados por el personal de los operadores, se extrajeron aquellos registros en los que los niveles de carga de la batería al final eran superiores al valor inicial, lo que significa que fueron viajes en que se realizó la recarga del vehículo. Se asumió que todas las labores de mantenimiento, limpieza y recolocación de vehículos se realizaron en los viajes de recarga, puesto que generalmente sucede así por motivos de optimización operativa.

En cuanto a los registros que podían deberse a problemas de conectividad de vehículos en concreto, los cuales fueron residuales, sus características mostraron que no se produce desplazamiento y no hay consumo de batería. Es decir, tendrían el mismo comportamiento que una reserva o varias reservas sucesivas de un usuario que finalmente decide no realizar el viaje y cancela $y$, por lo tanto, ya estarían extraídos de la base de datos con viajes reales. 


\section{ANÁLISIS DEL IMPACTO DE LOS SISTEMAS DE FREE-FLOATING CARSHARING EN ENTORNOS URBANOS UTILIZANDO DATOS WEB: APLICACIÓN A LA CIUDAD DE MADRID}

\section{BLOQUE IV. TRABAJOS PUBLICADOS}

\section{IV.1. LISTADO DE LAS PUBLICACIONES ORIGINALES}

La producción científica de la presente tesis doctoral se ha materializado en tres artículos publicados en revistas indexadas en el Science Citation Index, que se describen a continuación:

\begin{tabular}{|c|c|c|c|c|c|c|}
\hline Autores & \multicolumn{6}{|c|}{ María Ampudia-Renuncio, Begoña Guirao, Rafael Molina-Sánchez } \\
\hline Título & \multicolumn{6}{|c|}{$\begin{array}{l}\text { The impact of Free-Floating Carsharing on sustainable cities: analysis of first } \\
\text { experiences in Madrid with the university campus }\end{array}$} \\
\hline Revista & \multicolumn{6}{|c|}{ Sustainable Cities and Society - Elsevier (ISSN: 2210-6707) } \\
\hline Volumen $\left(n^{\circ}\right)$, pág & \multicolumn{6}{|l|}{$43(2018), 462-475$} \\
\hline Fecha publicación & \multicolumn{6}{|l|}{ Noviembre 2018} \\
\hline DOI & \multicolumn{6}{|c|}{ https://doi.org/10.1016/j.scs.2018.09.019 } \\
\hline 2018 JCR Edition & Índice de impacto & 4.624 & Cuartil & 1 & Categoría & Energy and Fuel \\
\hline 2018 SJR Edition & Índice de impacto & 1.1 & Cuartil & 1 & Categoría & Transportation \\
\hline Autores & \multicolumn{6}{|c|}{$\begin{array}{l}\text { María Ampudia-Renuncio, Begoña Guirao, Rafael Molina-Sánchez, Cristina Engel } \\
\text { de Álvarez }\end{array}$} \\
\hline Título & \multicolumn{6}{|c|}{$\begin{array}{l}\text { Understanding the spatial distribution of Free-Floating Carsharing in cities: Analysis } \\
\text { of the new Madrid experience through a web-based platform }\end{array}$} \\
\hline Revista & \multicolumn{6}{|c|}{ Cities - Elsevier (ISSN: 0264-2751) } \\
\hline Volumen $\left(n^{\circ}\right)$, pág & \multicolumn{6}{|l|}{$98(2020), 102593$} \\
\hline Fecha publicación & \multicolumn{6}{|l|}{ Marzo 2020} \\
\hline DOI & \multicolumn{6}{|c|}{ https://doi.org/10.1016/j.cities.2019.102593 } \\
\hline 2018 JCR Edition & Índice de impacto & 3.853 & Cuartil & 1 & Categoría & Urban Studies \\
\hline 2018 SJR Edition & Índice de impacto & 1.44 & Cuartil & 1 & Categoría & Urban Studies \\
\hline
\end{tabular}

\begin{tabular}{|c|c|c|c|c|c|c|}
\hline Autores & \multicolumn{6}{|c|}{ María Ampudia-Renuncio, Begoña Guirao, Rafael Molina-Sánchez, Luis Bragança } \\
\hline Título & \multicolumn{6}{|c|}{$\begin{array}{l}\text { Electric Free-Floating Carsharing for sustainable cities: Characterization of frequent } \\
\text { trip profiles using acquired rental data }\end{array}$} \\
\hline Revista & \multicolumn{6}{|c|}{ Sustainability - MDPI Multidisciplinary Digital Publishing Institute (ISSN: 2071-1050) } \\
\hline Volumen $\left(n^{\circ}\right)$, pág & \multicolumn{6}{|l|}{$12(3), 1248$} \\
\hline Fecha publicación & \multicolumn{6}{|l|}{ Febrero 2020} \\
\hline DOI & \multicolumn{6}{|c|}{ https://doi.org/10.3390/su12031248 } \\
\hline 2018 JCR Edition & Índice de impacto & 2.592 & Cuartil & 2 & Categoría & Environmental Sciences \\
\hline 2018 SJR Edition & Índice de impacto & 0.549 & Cuartil & 2 & Categoría & $\begin{array}{l}\text { Geography, Development } \\
\text { and Planning }\end{array}$ \\
\hline
\end{tabular}




\section{IV.2. ARTÍCULO I: THE IMPACT OF FREE-FLOATING CARSHARING ON SUSTAINABLE CITIES: ANALYSIS OF FIRST EXPERIENCES IN MADRID WITH THE UNIVERSITY CAMPUS.}

Sustainable Cities and Society 43 (2018) 462-475

Contents lists available at ScienceDirect

Sustainable Cities and Society

journal homepage: www.elsevier.com/locate/scs

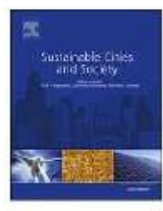

The impact of free-floating carsharing on sustainable cities: analysis of first experiences in Madrid with the university campus

María Ampudia-Renuncio, Begoña Guirao*, Rafael Molina-Sanchez

Departamento de Ingeniería Civil: Transportes y Territoria, ETSI Caminos, Canales y Puertos, Untwersidad Polltécnica de Madrid, Avda. Proféscr Aranguren. s/n, 28040 Madrid. Spain

A B S T R A C T

Carsharing systems have become an important tool for transport policymakers, as improvements in the perceived quality of these systems can reduce the number of cars, resulting in more sustainable cities. Recently, new types of car sharing such as free-floating carsharing (FECS) are surprisingly driving the growth of the carsharing markets in European and US cities and there is a need to estimate their spillover effects and study strategies to promote their use.

This paper contributes to the existing literature with a holistic evaluation of the impacts generated by FFCS on user behaviour in a specific population: university students. The added value of this research is that it provides the first analysis of the impacts of a FFCS (Car2go) system in Spain, and includes a comparison with previous similar research in the city of Hamburg. The methodology was based on a survey campaign of students (186 valid questionnaires), validated with over 330 sequential observations of available cars on the university campus. The results clearly show how the quality attributes of FFCS depend strongly on car availability and on the limit time and distance tolerated by each user to wait and walk in search of a free car respectively.

\section{Introduction}

The promotion of carsharing systems at the urban level has always been considered an important tool for reducing private car traffic and curbing pollution. Sustainable cities need to "green up" to decrease the impact of air pollution on their inhabitants and on their buildings. Several epidemiological studies have uncovered an association between exposure to atmospheric pollutants and adverse health effects, including a decline in life expectancy and an increase in mortality and hospitalisation rates. Society must modify its travel behaviour in order to live in more sustainable cities, and the new ICTs (Communications and Information Technologies) can play an important role in this long process.

In recent decades, the sharing economy has also given risen to a "shared mobility", a new scenario for planners and policy makers, who must design strategies to deal with the positive and negative impacts of shared mobility on transport networks. Some of these strategies include defining public rights of way, incentive zoning, transportation demand management and insurance and taxation (Cohen \& Shaheen, 2016). Carsharing systems, another type of shared mobility, have evolved in the last century due both to transport policies and to changes in society derived from the development of ICTs, the spectacular rise of the collaborative economy and the appearance of electric mobility.

Traditional station-based carsharing has already existed for more than 60 years: a fleet of cars can be shared by several users, who can drive a car when they need it, without having to own one (Ciari, Bock, \& Balmer, 2014). Although there is no officially accepted definition of carsharing, Millard-Ball, Murray, Ter Schure, Fox, and Burkhardt, (2005) gathered all the administrative definitions already in use and agreed that it can be defined as a "practice where multiple people in a for-profit or non-profit organisation share the use of multiple vehicles in exchange for a fee". This fee may include a fixed rate, a membership charge and a variable rate, usually depending on usage time.

Station-based carsharing is an economic and ecological altemative to private car ownership, although in recent years a wider set of cus tomers has been attracted by the more recent free-floating carsharing (FFCS) systems (Heilig, Mallig, Schroder, Kagerbauer, \& Vortisch, 2017; Kopp, Gerike, \& Axhausen, 2015). FFCS allows members to borrow a car from the street and return it anywhere in the service zone, and as it is a one-way, non-station-based system it offers users greater flexibility. This is the main reason FFCS systems have seen such rapid growth in the last decade (Herrmann, Schulte, \& Voß, 2014; Wielinski, Trépanier, \& Morency, 2015), contributing significantly to the worldwide growth in carsharing and increasing the attractiveness of this transport mode a an alternative to a self-owned car. Thanks to FFCS systems, the carsharing industry has never been as competitive as it is today.

Clearly, new ICTs (information and communication technologies) have enabled the emergence and boom of FFCS systems. ICT enhancements in public transport have traditionally included fleet management systems based on automatic vehicle location technologies,

Corresponding author.

E-mail addresses m. ampudia@alumnos.upm.es (M. Ampudia-Renuncio), bguirao@caminos.upm.es (B. Guirao), rafael. molina@ upm.es (R. Molina-Sanchez).

hitps://doi.org/10.1016/j.ses.2018,09.019

Received 27 April 2018; Received in revised form 10 September 2018; Accepted 14 September 2018

Available online 17 September 2018

221 0-6707/ C) 2018 Elsevier L.td. All rights reserved. 


\section{ANÁLISIS DEL IMPACTO DE LOS SISTEMAS DE FREE-FLOATING CARSHARING EN ENTORNOS URBANOS UTILIZANDO DATOS WEB: APLICACIÓN A LA CIUDAD DE MADRID}

which can be used to optimise routing and scheduling and feed realtime information into passenger information channels (Guirao, GarcíaPastor, López, Acha, \& Comendador, 2015). However, the car-rental market has also begun to benefit from new ICTs, and FFCS are no more than a type of car rental in which the vehicle can be optionally shared. Smartphone apps enable the user to simply search and book a car close to their current geographic position in the city inside a geofence (a virtual perimeter] defined by FFCS companies in which a person can hire and drop cars near or directly at their demand points. Flexibility is therefore the main attraction and the differentiator of FFCS systems, although it generates an imbalance in the cost of vehicle stock between zones, as noted by Jorge, Molnar, and de Almeida Correia, (2015). In addition, there are still many questions as to whether these systems increase the overall vehicle miles travelled by allowing easier one-way travel (automotive commuting) in urban areas, while negatively affecting traditional public transportation.

While there is extensive literature on the changes in user behaviour and the environmental benefits generated by traditional station-based carsharing (Loose, 2010; Wilke, 2009; Shaheen \& Cohen, 2007; Haefeli. Matti, Schreyer, \& Maibach, 2006; Shaheen, Cohen, \& Chung, 2009; Martin \& Shaheen, 2010), more research is needed to analyse FFCS systems, even in Europe. There is a need for a better understanding of the travel behaviour associated with this new system before analysing its social and environmental impacts, and the scientific approach followed has been exactly the opposite. The main research on FFCS (Martin \& Shaheen, 2016) was done in the U.S. using a survey campaign of Car2go (a FFCS provider company) users in five North American cities. Although the results are encouraging in terms of reducing greenhouse gas emissions, vehicle ownership and vehicle miles travelled, more focus is needed on user behaviour and perception of service quality.

The modal shift generated by FFCS must be studied in detail by population or activity group (students, commuters, self-employed workers, etc.). Examples of FFCS analysis in Europe can be found mainly in Germany, and focus on fuel FFCS vehicles (Ulm, Berlin, Hamburg), but without describing any systematic study methodology (Ciari et al., 2014; Firnkorn \& Müller, 2011; Herrmann et al., 2014). More research is needed on the behaviour of the FFCS users, and strategies to improve the reliability of the FFCS systems are still scientifically at an early stage (Herrmann et al., 2014). If users frequently find no available FFCS cars near their demand points, they are unlikely to accept the system as a substitute for another more reliable transport mode. FFCS reliability and quality of service depend heavily on the cars available at any time, that is, good spatial availability is a key factor for the success of the system (Niels \& Bogenberger, 2017). From the users perspective, even when they have already rented a car on one itinerary, the system offers no guarantee of finding another car on the way to the next activity or back home. The customers' experience determines their reliance on the system, which is why smart relocation strategies are so important and are the subject of serious study in this research area.

Coupled with the scarcity of specialised literature on FFCS, there is another drawback conditioning future research studies on this topic. Because of the ICT used in running the system, the companies that provide FFCS services control the entire database (big data) of car movements and user profiles, and are reluctant to share this information fully with the scientific community for two main reasons: first, for commercial and competitive aspects, and second, because the results of the scientific studies (if they point to an increase in pollution or a decrease in the use of public transport, for example) can damage the image of FFCS or serve as an argument for local governments to enact regulations against FFCS carsharing. These services generally depend on privileged access to street space (uncongested streets, free or cheap parking), meaning transport planners would be "gatekeepers" (Le Vine, Adamou, \& Polak, 2014) of this new shared-mobility marketplace, and in a position to allow the private sector to reach their customers or prevent them from doing so. Studies by the scientific community on
FFCS user behaviour and their impact on urban mobility are today especially relevant for public transport planners and government needs.

This paper contributes to the existing literature by providing a disaggregated assessment of the impacts and reliability generated by FFCS on user behaviour, focused on the student population. Potential FFCS users $(\mathrm{N}=186)$ were surveyed in the largest Madrid campus (Ciudad Universitaria), and the results were compared to a similar survey from the European city of Hamburg. The survey was also validated using an ad-hoc data base (not provided by the FFCS provider company, Car2go), of more than 330 sequential observations of avail able cars in the survey area through the operator's website. The ac cepted maximum distance between users and a Car2go vehicle tested in the survey campaign was then compared to the real availability of cars in the study zone. The added value of this research is that it provides the first analysis of the impacts and reliability of a Car2go system in Spain, a country with a long tradition of public transportation use where FFCS have never been implemented.

The article has been divided into the following parts in order to describe the research as a whole: introduction (Section 1); a review of the literature on FFCS impacts on the environment and user behaviour (Section 2); a description of the Madrid case study with an inventory of the parking space and an analysis of FFCS car availability using the database of web observations (Section 3); the presentation of the survey campaign, with a comparison to the Hamburg results, and their validation with the real availability of cars in the study zone (Section 4) and finally, the presentation of the most important conclusions and policy recommendations (Conclusions section).

\section{Free-floating carsharing: an overview}

When station-based carsharing evolved towards more flexible sys tems, the first type to be implemented was one-way carsharing (Jorge, Correia, \& Barnhart, 2012): a scheme where users collect the car at a station and return it to the station of their choice, not necessarily to the station where they initially collected the car. For Schaefers (2013), the next step (FFCS) involves the user simply returning the car to any public parking space inside a specific operating area. FFCS is of course an evolution of the one-way carsharing model.

The pioneer of this system was Car2go, a Daimler AG subsidiary which launched its first fleet in October 2008 in a small German city called Ulm (Firnkorn \& Müller, 2011; Kortum, Schönduwe, Stolte, \& Bock, 2016). Since then, the company has expanded throughout the world. Today it operates in $\mathbf{2 5}$ cities in Europe, North America and Asia, with a fleet of 14,000 Smart and Mercedes cars, and reached 3 million members by the beginning of 2018 (Car2go blog, 2018a). The second system worldwide in terms of membership and number of vehicles operating was also supported by a car manufacturer, the BMW Group The German company created DriveNow in Europe in 2011 (Kopp et al., 2015; Kortum et al., 2016; Muller et al., 2017) as a joint venture with the car rental company Sixt (BMW blog, 2011), although it has recently acquired the total share (BMW blog, 2018). BMW fully owns ReachNow in the U.S., launched in 2016 (BMW blog, 2016). Counting both systems, the fleet now has almost 8000 vehicles in 13 European and three North American cities. According to a DriveNow's data (DriveNow blog, 2017), the operator passed the one million-member mark at the end of 2017. Daimler AG and the BMW Group have recently agreed to combine their mobility services (Car2go blog, 2018b). However, other major car manufacturers have joined this business model and have created their own companies to compete, such as the French PSA Group (PSA Group, 2017) and the South Korean Hyundai Motor Group (Hyundai Motor Europe, 2017).

This new scenario is changing a large number of functional relationships within the automotive sector; the new strategy pursued by car rental firms is only one example of this. For many years car renta firms were major customers of carmakers, but both are now competing for the same market in urban mobility services (Firnkorn \& Muller 
2012). FFCS are rapidly penetrating the market. Car2go's market penetration rate in Germany, for example, is approximately 25 times higher than the weighted average market penetration of traditional carsharing providers (Firnkom \& Müller, 2011). As these figures show, the shared-mobility marketplace may have reached a tipping point, as major commercial operations based on more flexible carsharing models (like FFCS) are beginning to report high profitability (t.e Vine et al, 2014).

Despite the rapid rise in FFCS users, the scientific community has refused to directly transfer the valuable existing carsharing research results to FFCS (Firnkorn \& Müller, 2011). Becker, Ciari, and Axhausen. (2017) justify this by pointing out that due to their different format and price structure, both systems appear to target different markets and that FFCS, because of its flexibility, has a substantial market potential in the form of a new pool of travellers who were not attracted by existing station-based systems (Kopp et al,, 2015). The literature has accepted -among others- the following positive effects for traditional stationbased carsharing systems in restricted environments (urban geofence):

1) Environmental impacts (Shaheen \& Cohen, 2007), including a reduction in total $\mathrm{CO} 2$ emissions (Haefeli et al., 2006).

2) Individual reduction in vehicle-kilometres travelled (Shaheen et al. 2009).

3) Reduction in the average number of vehicles per household (Martin \& Shaheen, 2010).

However, many authors have pointed out that these effects might not be replicated to the same extent or may even be negative for FFCS (Wilke and Bongardt, 2005). The concept of FFCS as a "Product Service System (PSS)" changes the approach of the assessment of this new type of mobility (Mont \& Plepys, 2008; Mont \& Tukker, 2006; Mont, 2004). The initial move to a PSS has been largely motivated by the need of traditional manufacturing firms (in this case, car manufacturers) to cope with changing market forces, and the recognition that services in combination with products could provide higher profits than products alone. One such example is FFCS and its rapid rise. The overall impact of a traditional carsharing system equals the total number of users multiplied by their weighted average individual impact. However, a rise in the number of users not only increases the positive effects but also produces a multiplier effect in regard to negative impacts: for example, how the customers modify their average public transportation use, and how this affects traffic congestion. Le Vine et al. (2014) quite rightly pointed out that although the public sector does not directly deliver shared-mobility services, transport planners play a decisive role in these markets, as one-way carsharing services (primary FFCS) depend on privileged access to street space (uncongested streets, free or cheap parking space) which can only be granted by the public sector.

Due to the fact that the transfer of the traditional impacts of a carsharing system to FFCS is practically dismissed by the scientific community, more research needs to be done on FFCS systems, even in Europe. This fact has occurred simultaneously with the arrival of electric vehicles in the carsharing market, further hindering the analysis of FFCS systems. This is because electric cars are experienced by users as a new type of transportation mode in which the "limited range" (associated to the distance travelled and the location of recharging points) has been demonstrated to be a real preoccupation for customers: a notion called "range anxiety" (Wielinski, Trépanier, \& Morency, 2017). The users' perception (and behaviour) of a FFCS based only on electric vehicles is quite different from their perception of a FFCS based on fuel or even hybrid vehicles (Mueller, Schmoeller, \& Giesel, 2015). Recent studies by Wielinski et al. (2017) in Montreal (Canada) with a mixed FFCS fleet of electric and hybrid cars (Auto-mobile, Communauto) analysed the user choice between electric and hybrid cars. Using a binomial logit model to find the probability of choosing an electric car when there is a choice, the results revealed that travel distance is a key factor. electric vehicles were less popular for distances of over $24 \mathrm{~km}$.
Moreover, cold temperatures and being a female (gender) also decreased the probability, while higher energy levels increased it. The spatial analysis showed a difference in behaviour between both car technologies, with trips made by electric cars being less spatially dispersed than those of hybrid cars. The rapid rise of the electric vehicle market will affect the new FFCS systems and consequently customer behaviour, in addition to producing environment impacts in urban scenarios.

European research on FFCS systems has focused mainly on fuel vehicles and on German (Ulm, Berlin, Munich and Hamburg) and Swiss (Zurich and Basel) experiences, with different targets and methodologies. Some recent studies in France have shown an interest in these new systems (6t-Bureau de Recherche, 2013, 2014). The future of "one-way carsharing" (Autolib'), as an alternative to the private car in the city of Paris, has been analysed and compared (6t-Bureau de Recherche, 2014) to "round-trip" systems (Mobizen). The results, obtained through survey methodology, show that the number of cars owned by Autolib users decreases by $23 \%$ after they sign up to the service, but this percentage is much higher for Mobizen users ( $-67 \%$ of vehicles owned) and for carsharing users outside the Paris region $(-66 \%)$. Taking into account only the decrease in the number of cars, each Autolib' car replaces 3 private cars, while each Mobizen car replaces 7 private cars. However, Autolib' service has 18 times more cars than Mobizen and consequently, allows it to reach a far higher number of users than Mobizen. Thus overall Autolib' replaces 6000 private cars and frees 4000 parking spaces, while Mobizen replaces 784 cars and frees 672 parking spaces. Although these positive results obtained in Paris, Auttolib and Mobizen are station-based systems and not directly comparable to FFCS systems.

Returning to the German research, the study in Ulm (Firnkom \& Muiller, 2011) assessed the environmental effects of the FFCS fue system (Car2go) operating in the city by calculating three scenarios. The prognosis, based on a quantitative survey, considers the five-year period after the launch of Car2go in 2009, and indicates a $\mathrm{CO} 2$ reduction per average Car2go user. More than a quarter of the survey respondents stated that they might forgo a car purchase if Car2go were offered permanently. In the case of Car2go in Ulm, the magnitude of the predicted vehicle reduction was verified by comparison with the officia car registration figures until 2014. Firnkom (2012) subsequently validated these results for Ulm through triangulation using retrospective data. The study case of Berlin (Ciari et al., 2014) compares theoretical demand for station-based and fuel FFCS using MATSim, an agent-based simulation software. The main finding is the apparent complementarity of station-based and FFCS systems, together with the existing high potential to extend carsharing services further in Berlin. This comparison was also made in the Montreal case study (Wielinski et al., 2015) with a different methodology: the study was based on four datasets of transactional data for both services (Communauto), GPS traces for freefloating cars, and a targeted survey designed to gain a better understanding of the use of the new service. The results showed that com pared with traditional carsharing, more women were members of the free-floating service, and the trip distances and durations were much shorter. Shopping was the most important activity, and there was a concentration of trip ends near the central business district in the midday period. When asked what mode people would have used in the absence of free-floating cars, the answer was public transport, taxis and walking. More recently, Ciari, Balac, and Balmer, (2015) analysed the impacts and implications of different parking prices on the demand for FFCS in the city of Zurich, and found that FFCS vehicles can make more efficient use of parking space than private vehicles. Again in Switzerland, user groups and usage patterns were compared between stationbased and FFCS systems, both operating in Basel (Becker et al., 2017). The authors point out that the systems attract different user groups and are also used differently. It is worth noting that they found that membership is governed by factors other than the frequency of use of the system. 


\section{ANÁLISIS DEL IMPACTO DE LOS SISTEMAS DE FREE-FLOATING CARSHARING EN ENTORNOS URBANOS UTILIZANDO DATOS WEB: APLICACIÓN A LA CIUDAD DE MADRID}

Lastly, the case study of Hamburg (Herrmann et al, 2014; Schulte \& Voß, 2015) took a completely different approach, more oriented to the user perspective. This research set out to investigate appropriate relocation strategies for the new fuel FFCS system (Car2go) in Hamburg through a survey-based evaluation, new relocation strategies, and a discrete-event simulation model with real time data from Car2go. The results indicate that car availability is crucial for customer acceptance as part of the FFCS service quality, which is also noted by Niels and Bogenberger (2017); however, customers are open to smart relocation strategies. The frequency of traditional public transportation (bus, metro, tramway) in urban areas is one of the main attributes of the users' perception of service quality (Guirao, Garcia-Pastor, \& LópezLambas, 2016), and the first surveys of FFCS users point to the same attribute: availability of cars (frequency). Together with an increase in the number of cars, relocation strategies in FFCS mobility represent a procedure for increasing service frequency, which is why this procedure is so important. The miles driven by FFCS staff to redistribute the vehicles must also be considered in any sustainability and operating analysis. Considering fuel FFCS systems in the U.S., staff miles were found by Martin and Shaheen (2016) to range between 3.4\% and 7.5\% of all FFCS miles driven. In the case of San Diego, with a fully electric fleet of vehicles, the miles driven for redistribution purposes account for $17 \%$ of all miles (Martin \& Shaheen, 2016), mainly due to the need to move the vehicles to depots for recharging. There is extensive literature on relocation strategies for traditional station-based carsharing (Fan, Machemehl, \& Lownes, 2008; Kek, Cheu, \& Chor, 2006; Kek, Cheu, Meng, \& Fung, 2009; Nair \& Miller-Hooks, 2010), although these systems usually have fewer options than FFCS systems for interacting with their users and dynamically offering them incentives. For the Hamburg study, Herrmann et al. (2014) focused on operator-based strategies and pricing incentives for users, a model that has also been used in this paper for the Madrid case study. In addition to carsharing, similar approaches for repositioning empty logistics resources can be found in bike sharing (Raviv, Tzur, \& Forma, 2013) and container shipping (Song \& Dong, 2011).

In the US context, 2016 was a milestone for FFCS systems, as they were endorsed by the positive environmental results of an extensive study (including five North American cities) by the Transportation Sustainability Research Center of UCA Berkeley (Martin \& Shaheen, 2016). This research followed the methodology used previously in Ulm (Fimkorn \& Müller, 2011) to quantify the impacts of FFCS (Car2go) on vehicle ownership, modal shift, vehicle miles travelled and greenhouse gas (GHG) emissions. The database was compiled using a survey campaign of Car2go users in five cities (Calgary, San Diego, Seattle, Vancouver and Washington D.C.) together with vehicle activity provided by Car2go, to evaluate the total travel by Car2go vehicles in a city in one year, with a profile of the frequency of use by the broader Car2go population. Due to the differences in typology between the cities considered and the FFCS, the authors recognise that there are a variety of impacts on travel behaviour, and the magnitude of these impacts varies across the five cities (see Table 1). Although these results are subject some uncertainty in their measurement, they suggest that between $2 \%-5 \%$ of the Car2go population sold a vehicle due to Car2go in the cities in the study. While these percentages are nominally only a small share of the re-weighted sample, at the population level they translate into vehicle reduction impacts that exceed the number of Car $2 \mathrm{go}$ vehicles operating on the streets of these cities. This is the key issue in the methodology that leads the authors to deduce a reduction in overall GHG.

The direct transfer of these results to European capitals is controversial for several reasons. The first concerns the denser network of public transportation in European cities, which is more sensitive to the rapid rise of FFCS vehicles operating in the streets (negative multiplier effects, mentioned before). Secondly, fuel FFCS systems users perceived hybrid and fully electric FFCS differently, requiring a disaggregated study. Lastly, even within Europe, user behaviour towards FFCS depends strongly on the type of city and the user's socioeconomic profile. For example, it is clear that this system could be particularly successful among the tech-savvy millennial generation, who, through a combination of financial and environmental concerns, coupled with the widespread adoption of smartphones (Delbosc, 2017), are choosing to share access to products and mobility services rather than opt for individual car ownership (Hwang \& Griffiths, 2017). There are some special groups that warrant a more detailed study, such as commuters, students and weekend leisure FFCS users.

The next section describes the Madrid case study, in which university students are the target user profile for analysis. The added value of this research is that it is the first FFCS study in a Spanish city, and as it was carried out at a time when Car2go was the first and only FFCS operator in the city (October-November 2016), it provides an opportunity to study the user profile and quality of service perception. Moreover, as it had been implemented in Madrid one year earlier, on November 11, 2015, the Car2go system had by this time completed its maturation.

\section{Madrid case study}

The first FFCS implemented in the city of Madrid (November 2015) was operated by Car2go, a company with a long experience in providing this type of service in 24 European and U.S. cities and one in Asia (Chongqing). In order to find a suitable type of city to implement a FFCS system, and to highlight the differences between the European and U.S. cities with Car2go operation, Fig. 1 describes the relations between population density, city areas and number of users. The graphs show a heterogeneous group of situations and may not lead to any linear relation of dependence between variables (city population, population density, number of users, number of FFCS fleet vehicles). It is difficult to identify clear patterns in the differences between European and U.S. cities, probably because more information is needed on the quality of the existing public transportation and because there are some cities in this sample with more than one FFCS operator (not only Car2go].

Most vehicles used by Car2go in their cities are the 2-seater commercial model Smart Fortwo, as is the case of Madrid ( 500 vehicles and more than 185,000 members in 2017). Due to the compactness of the Smart Fortwo, it is well suited to moving and parking in congested cities with limited on-street parking space. Fig. 2 shows the $42 \mathrm{~km}^{2}$ service area operated by Car2go in Madrid (which basically corresponds to the city centre encircled by the M-30 orbital motorway) and the location of the case study area (Ciudad Universitaria). From the point of view of parking space availability, the municipal regulations in Madrid (Ayuntamiento de Madrid, 2005, 2012) allow free parking for electric vehicles in regulated streets, which are all located inside the area within the M-30 orbital motorway. This administrative fact has definitely en couraged the implementation of the first FFCS systems in Madrid, which have enjoyed a privileged situation in environmental terms, as the Car2go fleet is totally electric and there are only two other cities in Europe operated by Car2go with this situation: Stuttgart and Amsterdam. In addition to this privilege, the fares during the first years of operation were lower in Madrid than in all the other countries with Car2go systems, making this FFCS system very attractive for new users. As the second FFCS company (Emov, a subsidiary of the PSA Group) to enter the Madrid market recently started operating (19 December 2016), there was a suitable period of time in which the quality of service perceived by new users was associated only to the Car2go operation. Our study was conducted in precisely this time period, and includes the behaviour and preferences associated to a population group that has been shown by the literature to have a high potential for loyalty: millennials and students. Some recent studies have revealed that millennials tend to buy fewer cars and use more collaborative consumption services (Delbosc, 2017; Hwang \& Griffiths, 2017). Dempsey (2016) also found in her study that survey respondents in 
Table 1

Madrid survey questionnaire structure.

\begin{tabular}{|c|c|}
\hline Item & Options for response \\
\hline Student's address in Madrid & Postcode \\
\hline Student's address located inside the M- 30 ? & Yes/No \\
\hline Experience as a Car2go user & Yes/No \\
\hline Availability of a private car for use on faculty trips & Yes/No \\
\hline Time student's class starts (estimated time of arrival at faculty) & Open answer \\
\hline Time student's class ends (estimated time of return home) & Open answer \\
\hline Attendance at campus libraries on Saturday & Yes, usually / No, never / Yes, sometimes \\
\hline Transport mode used to go to and from the faculty & Public transport / Own car / Other (specify) \\
\hline Limit of distance to walk in order to reach an available Car 2 go vehicle & Less than $300 \mathrm{~m} / 500 \mathrm{~m}$ or less $/ I$ don't mind walking more than $500 \mathrm{~m}$ \\
\hline Limit of waiting time if there is currently no car available within the desired distance & $30 \mathrm{~min}$ or more / Less than $30 \mathrm{~min} /$ Less than $15 \mathrm{~min}$ \\
\hline Alternative transportation mode chosen when waiting time is exceeded & Public transport / Own car / Other (specify) \\
\hline Willing to book a more distant car for a $30 \%$ fure discount? & Yes / No / No, there must be a higher reduction \\
\hline Willing to indicate the destination of the trip at the start of travel? & Yes/No \\
\hline Type of incentive preferred & Free minutes $/ 30 \%$ fare discount \\
\hline
\end{tabular}

college were less likely to own a car. University carsharing has been widely analysed in the U.S., especially with round-trip systems like Zipcar (Stocker, lararus, Becker, \& Shaheen, 2016), and the results show that $5.2 \%$ of college/university members sold or postponed purchasing a vehicle due to Zipcar. These results cannot be directly extrapolated to the Spanish campus because the structure of most Spanish campuses is different from the U.S. (they are more integrated in the cities), and particularly because the type of FFCS implemented in Madrid, like Car2go, is a "one-way" and "free-floating" carsharing system

Ciudad Universitaria is located in the northwest of the city in one of the 21 districts in the municipality of Madrid, where residential activity is practically non-existent. Two of the oldest and most prestigious universities in Madrid are located in this area (Universidad
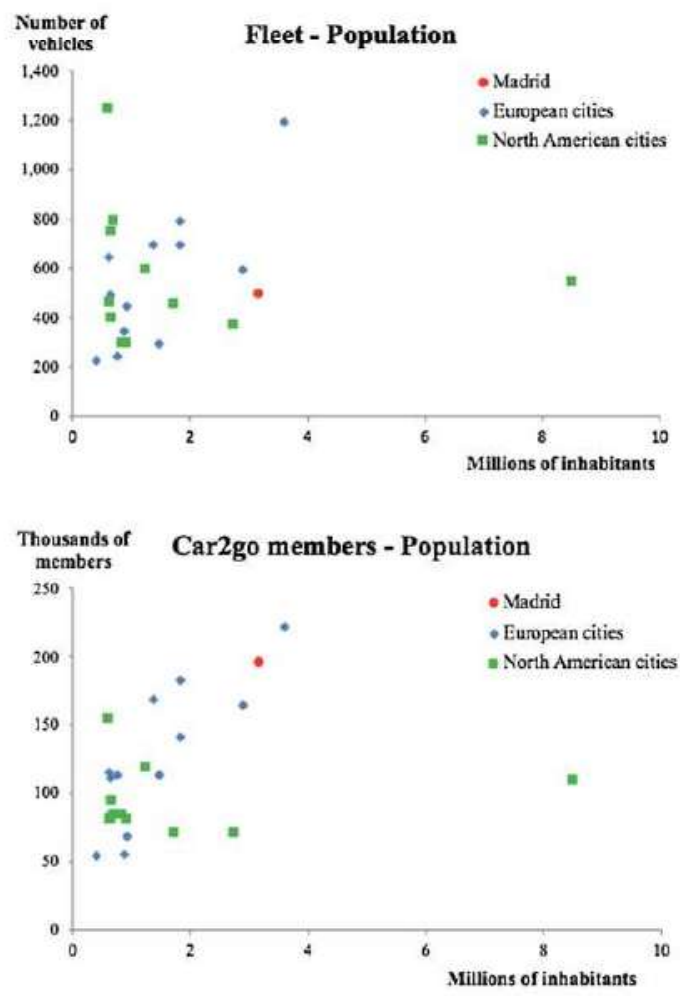

Complutense de Madrid UCM and Universidad Politecnica de Madrid UPM), and it can be considered the largest campus in Madrid in terms of students and faculty and administrative staff. An estimate for the 2014-2015 academic year gave a figure of 72,125 students, 5836 faculty and 4105 administrative staff, making a total of 82,066 people. From the parking point of view, the area of Ciudad Universitaria is a special case inside the M-30, as a large percentage of the limited onstreet parking spaces are unregulated, and there are also three large unregulated parking areas in front of the main entrance to the building. Parking areas for faculty (usually with entry restrictions) are not considered in this study, as the FFCS company does not allow vehicle dropoff in areas not publicly accessible by the next user. Fig. 3 shows the location of the faculties (UPM and UCM) and the main metro and urban
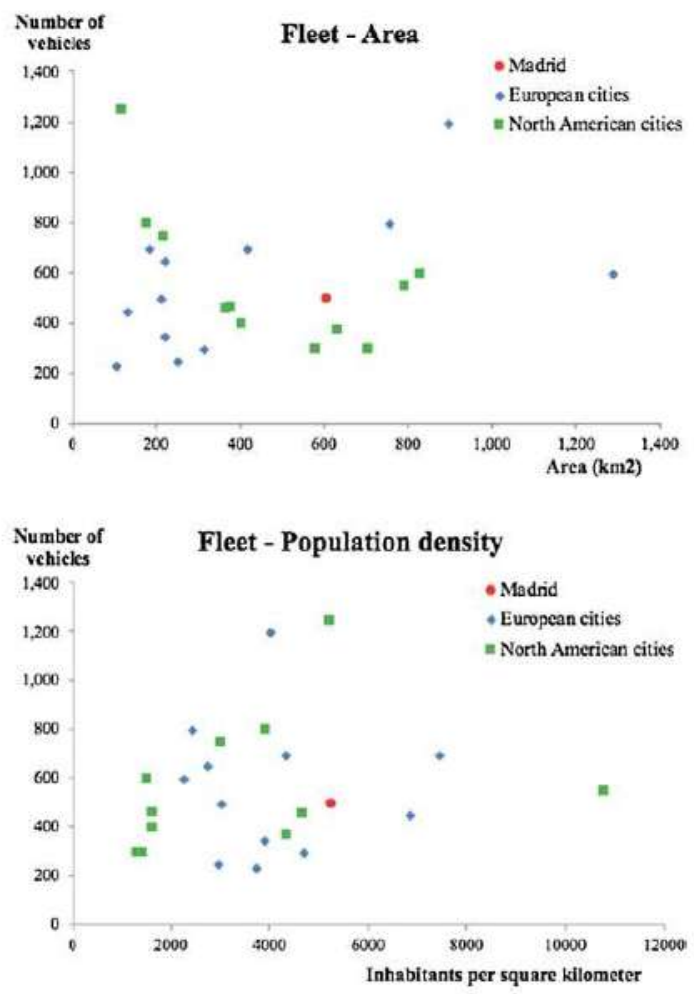

Fig. 1. Comparison of Car2go cities in relation to population, city area and car2go users and fleet. (source: bitps:/www.car2go.com, accessed in May 31, 2017). 


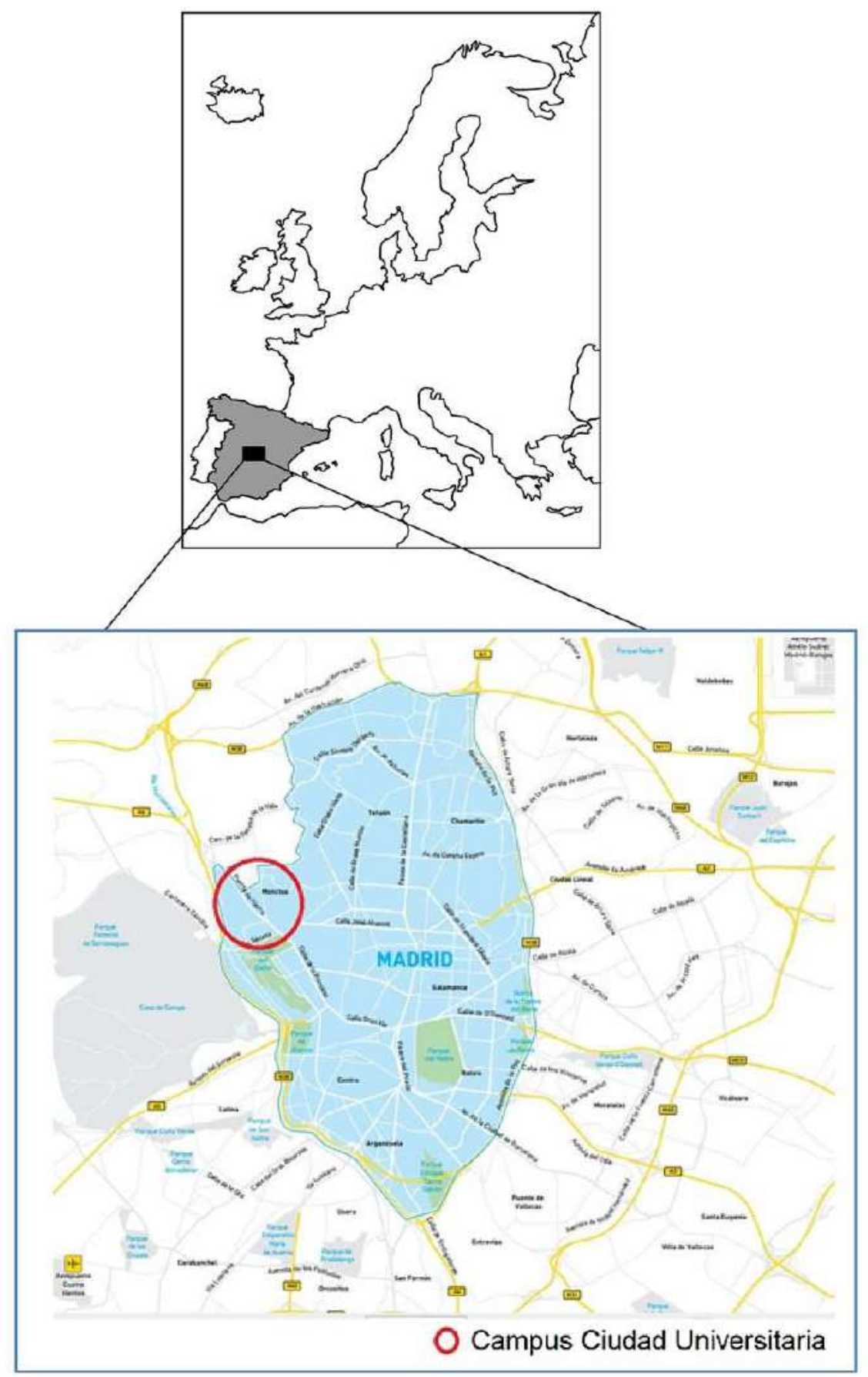

Fig. 2. Location of the Car2go service area in Madrid and the case study geofence.

bus stations. The main station is "Ciudad Universitaria" (represented with a 500-m radial catchment) and although it is located in the geographic centre of the campus, some of the faculties are more than a 10 minute walk from the station entrance. Public transportation services in
Ciudad Universitaria are high quality ( 3 underground stations and more than 3 bus lines), although service frequency at weekends is lower due to the reduction in academic activity. Some university libraries are open at weekends, but this activity represents a small percentage of the 

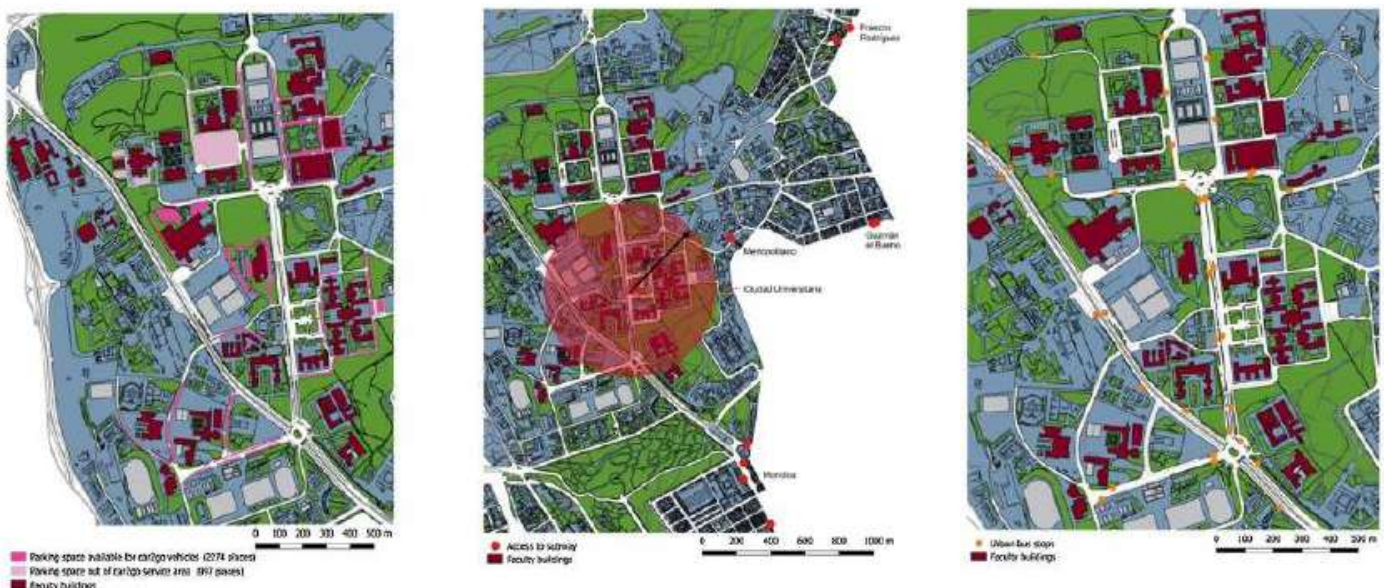

Fig. 3. Location of the UPM and UCM faculties in the area of Ciudad Universitaria, available parking space (street and parking lots) and main bus and underground stations.

students' mobility in comparison to weekdays.

As part of this research, a detailed inventory was made of public parking spaces (accessible simultaneously by private cars and the FFCS system) in Ciudad Universitaria, as it was not available at the administrative level. The results show a low availability of parking spaces ( 3271 places) to meet the mobility needs of 82,066 people, who are probably divided into morning and afternoon academic shifts, with greater importance of the morning shift. The location of this parking space is not homogeneously distributed. Fig. 3 shows the parking space available for Car2go vehicles, estimated at 2274 places, mainly onstreets, with a large car park located in the School of Civil Enginecring. There are another 2 large car parks ( 997 places) located outside the Car2go service area on the faculty premises, which are more than $500 \mathrm{~m}$ away from the metro station, and available for private cars.

The availability of Car2go vehicles to rent is dependent on parking space. The evolution of this availability can be registered through systematic observation and by counting the vehicles offered by the operator though its web page. This information is constantly refreshed in real time and allows the presence of cars in a study area to be tracked. As part of the research in this paper, these observations were programmed sequentially every $30 \mathrm{~min}$ from $00: 00 \mathrm{~h}$ on 3 October 2016 (Monday) to $24: 00 \mathrm{~h}$ on 9 October 2016 (Sunday), giving 48 screenshots in one day and 337 observations this week. In relation to the week selected, October is a month with regular academic classes and no special events or meteorological conditions (rain, low temperatures) were recorded in this case. Fig. 4 describes the evolution of available Car2go vehicles throughout the week, with details of the patterns on each day of the week.

The observations identified Monday as the day with the highest car availability (with a maximum of 32 cars recorded at 11:00), while Sunday is the day with lowest availability during the morning period. In general terms, the maximum each day appears after the morning congestion peak in the city, which is quite reasonable in view of the fact that FFCS charges per km travelled, and congestion makes the system less competitive. Minimum figures are registered in the evening and at night. Surprisingly, Saturday shows a higher number of available cars than Friday due to the lower academic load on, and to university library activity on Saturdays. The pattern during the day shows another maximum in the afternoon (17:00-18:00 h) although of lesser importance than in the morning. This maximum is very small on Mondays, but grows during the week to reach its peak on Fridays and Saturdays. These data are linked to academic activity, which in most faculties is structured into morning and afternoon shifts. Classes in the afternoon shift tend to start at 15:00/16:00 h, which explains the higher presence of Car2go vehicles recorded (once the cars are parked and available again for the next user). We know the percentage of students attending the afternoon shift is lower than for the morning shift, and Car2go availability is consistent with this information.

Other important information to be obtained to clarify these results is the percentage of students taking subjects (courses) structured into classroom-based courses and face-to-face tutorials (as opposed to distance courses). The idea of a student taking all the classes during a semester implies a fairly inflexible type of daily mobility, mainly for students in the morning shift. If students need only to attend some of the classes in their timetable, then Car2go can fit satisfactorily into their mobility plans. This study on availability does not take into account the mobility of cars due to the Car2go logistics. As mentioned in the state of the art, the relocation of FFCS is necessary to move cars from low-demand (at certain times of the day) to other high-demand areas. Until now, the cars have been physically relocated, as smart relocation strategies have not been implemented in Madrid. We have assumed as a hypothesis for this research that any available car has been dropped in Ciudad Universitaria by a previous user, not a Car2go worker, which is a less likely although still possible.

In order to better study the pattern of the students (as a group of Car2go users\} and their perception of the service quality linked to "frequency" (car availability), this research included the design and implementation of a survey campaign. It was clear that the user profile had to be collected for both the moming and aftemoon university shift. The faculty selected (School of Civil Engineering) for the survey campaign offers some interesting conditions in terms of the use of public transportation and its relation to the FFCS system: it is not located in the centre of the campus (the metro station is $700 \mathrm{~m}$ away) and there is a large car park available ( 326 parking places) close to the main entrance of the building.

The next section describes the survey campaign and analyses the results in order to validate the responses with the availability of FFCS only in this faculty area. Spanish students' willingness to walk (attitude towards walking) and the level of penetration of new Car2go smart relocation strategies are compared with a similar survey carried out in Hamburg. 


\section{ANÁLISIS DEL IMPACTO DE LOS SISTEMAS DE FREE-FLOATING CARSHARING EN ENTORNOS URBANOS UTILIZANDO DATOS WEB: APLICACIÓN A LA CIUDAD DE MADRID}

M. Ampudia-Renuncio et ai.
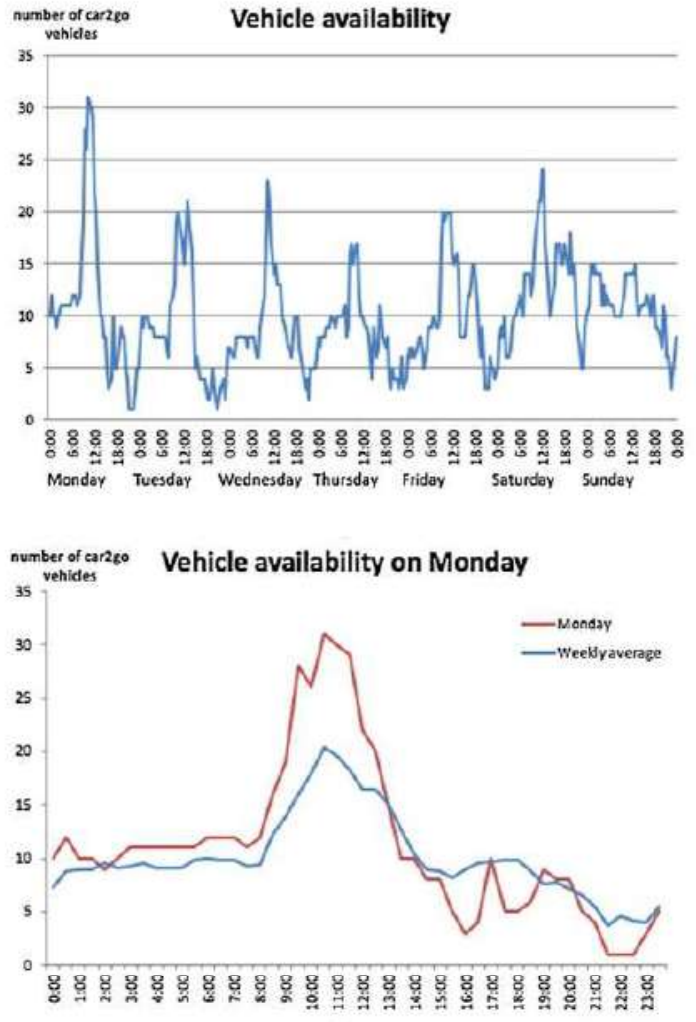

Sustainable Cities and Soctery 43 (2018) $462-475$
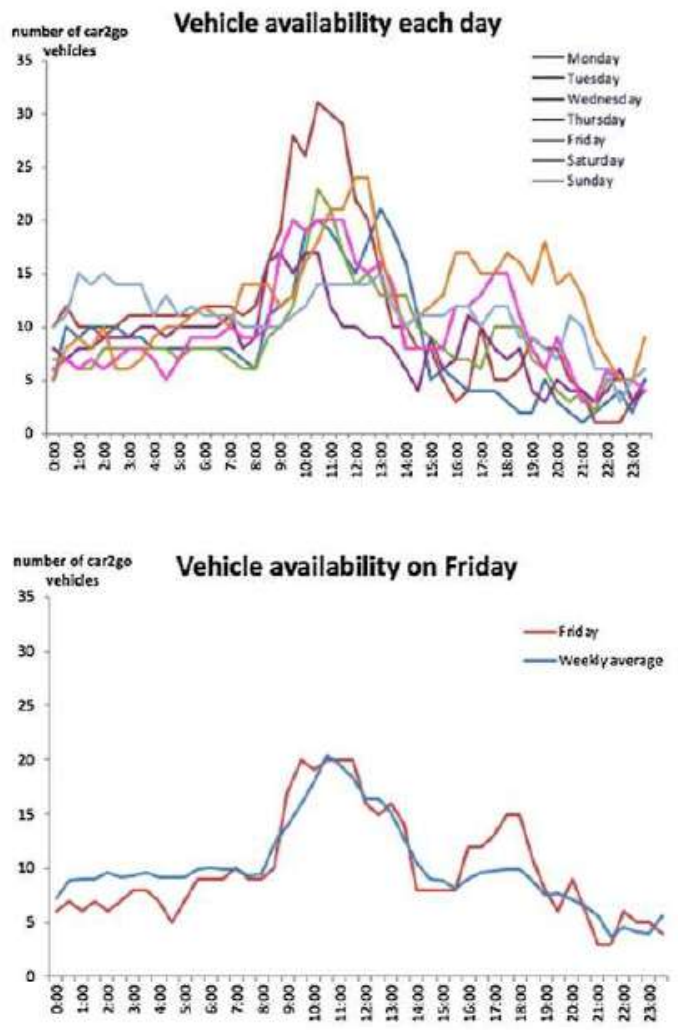

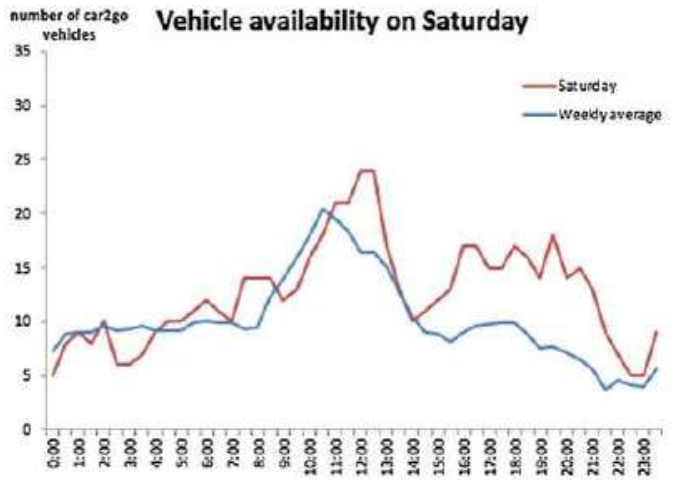

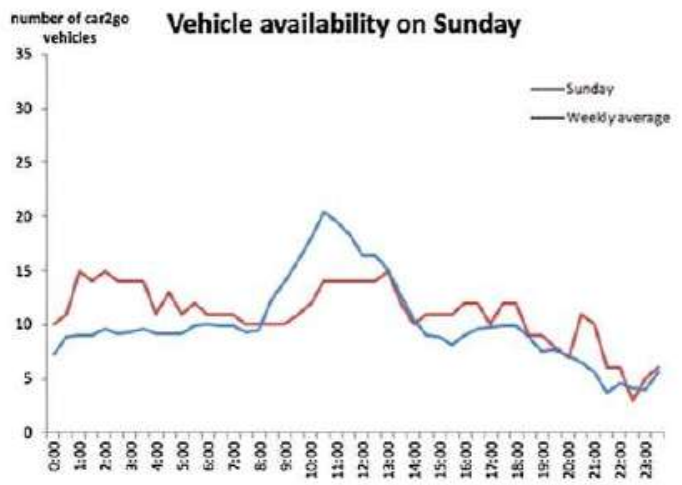

4. The survey campaign: Methods and results

The survey was conducted in the School of Civil Engineering in November 2016, obtaining 186 valid questionnaires, $47 \%$ from the morning and $53 \%$ from the afternoon shift. The questionnaires were printed and then distributed and collected at the end of the morning and aftemoon classes. The location of the faculty where the surveys were carried out is shown in Fig. 6, where the available parking space includes not only the large car park but also a street inside the faculty premises, making a total of 326 places. This faculty has two entrances (closely spaced), with the main one on the principal building façade in front of the large car park. This entrance is considered the origin or final destination of the trips in this research, so distance to the available Car2go vehicles is measured from this point in the building.

The questionnaire was intended to register students' perception of the new FFCS services (Car2go), depending on their experience as Car2go users or not, their transport background profile on faculty trips (private car or public transport), and their willingness to walk towards an available Car2go vehicle. Frequency has been demonstrated by the literature to be the main service quality attribute of public 


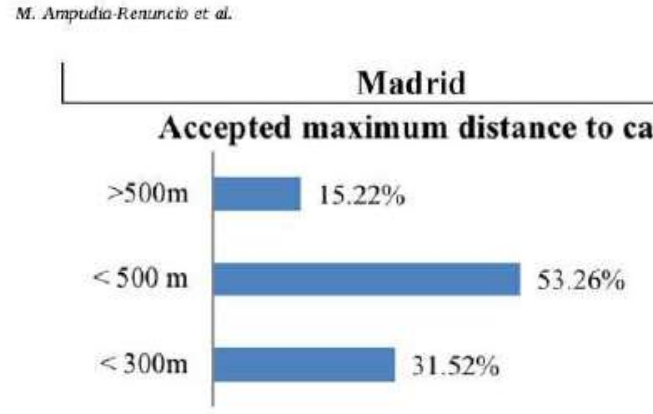

Accepted maximum waiting time

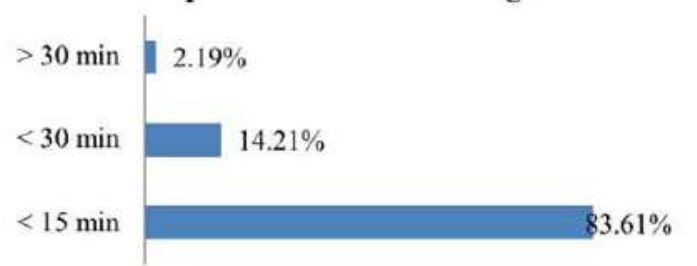

Book a more distant car for a $30 \%$

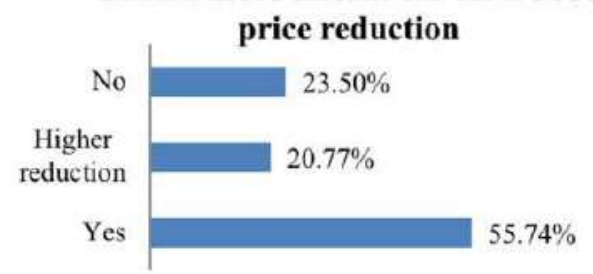

Determine the destination at start

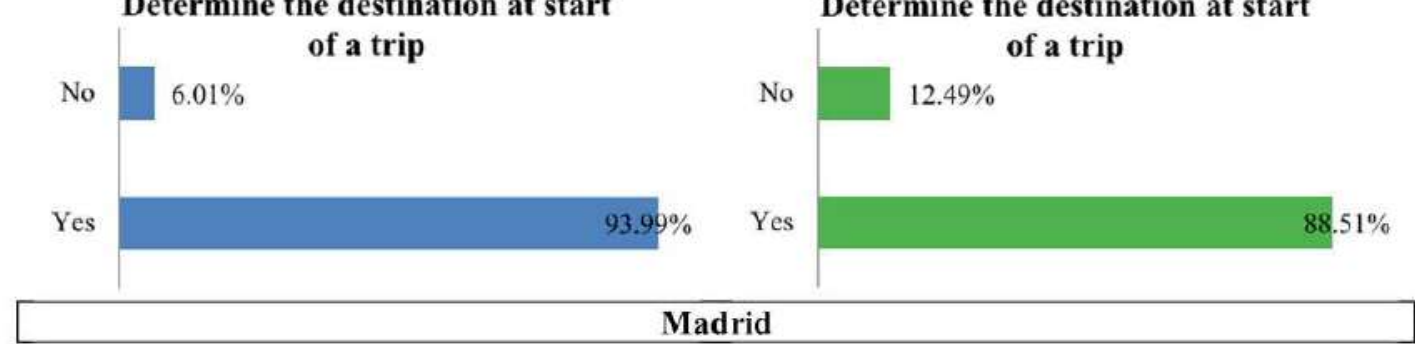

Accepted max. distance to car

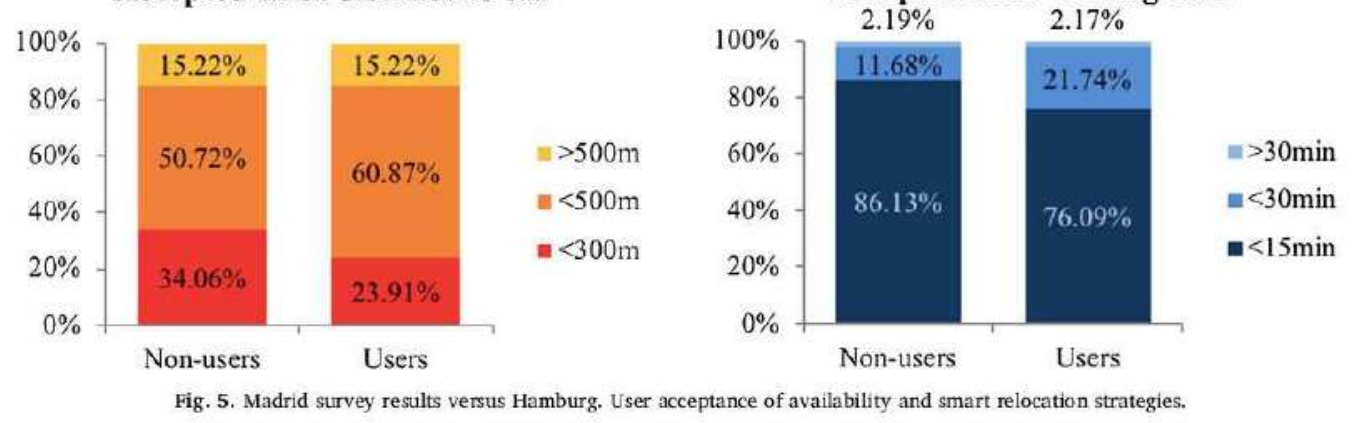

Book a more distant car for a $\mathbf{3 0} \%$

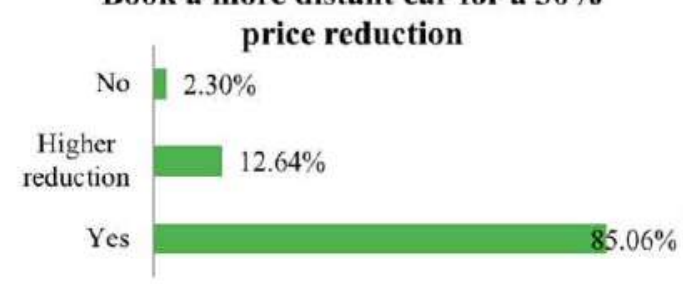

Determine the destination at start

Accepted maximum waiting time

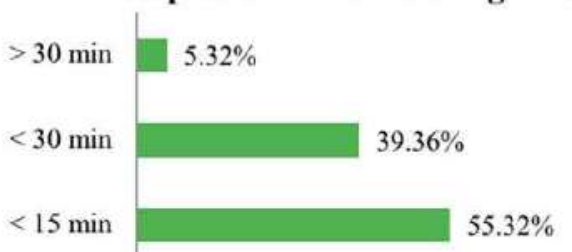

Hamburg

Accepted maximum distance to car

\begin{tabular}{l|l}
$>500 \mathrm{~m}$ & $20.43 \%$
\end{tabular}

$<500 \mathrm{~m} \quad 60.22 \%$

$19.35 \%$ 


\section{ANÁLISIS DEL IMPACTO DE LOS SISTEMAS DE FREE-FLOATING CARSHARING EN ENTORNOS URBANOS UTILIZANDO DATOS WEB: APLICACIÓN A LA CIUDAD DE MADRID}
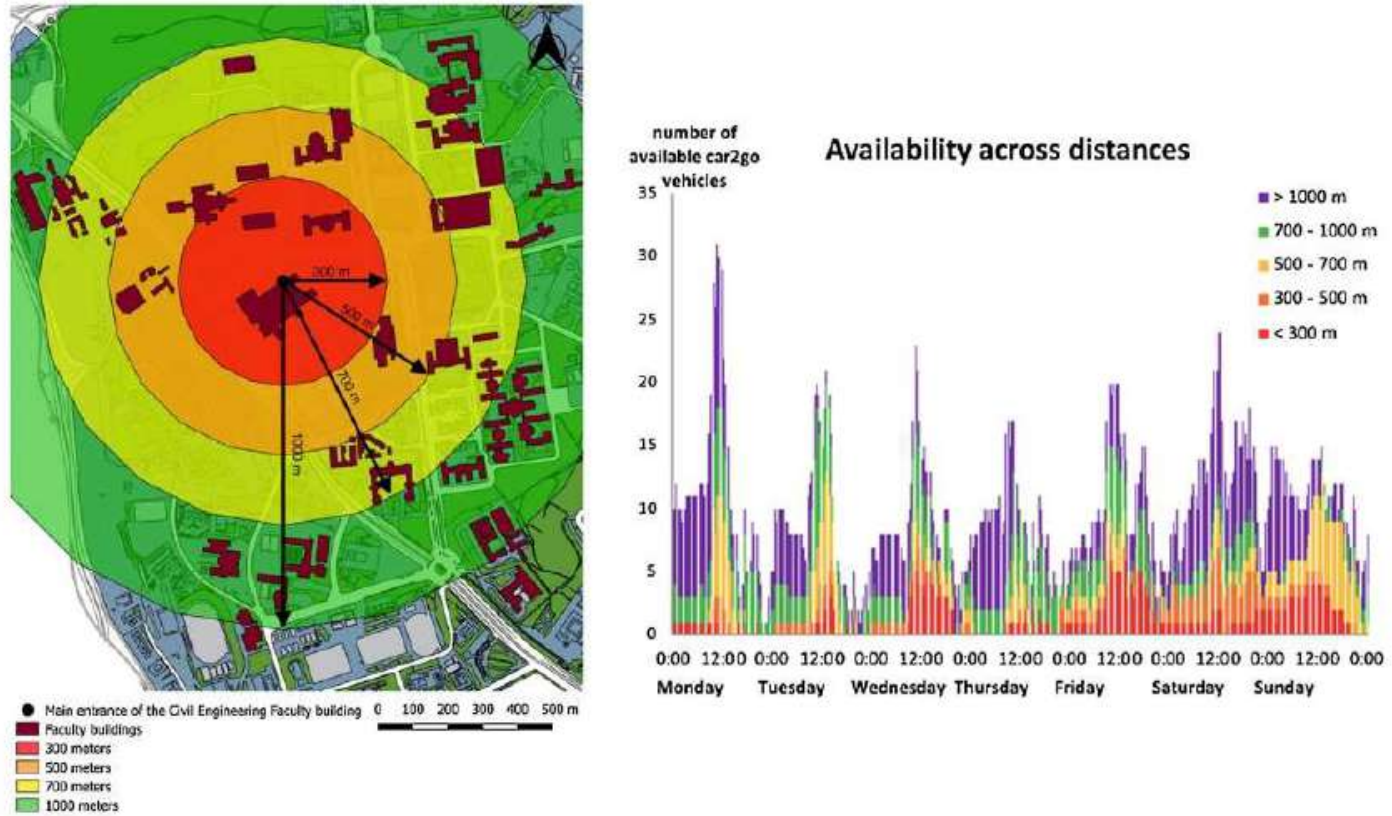

Fig. 6. Radius of influence in the case study based on the maximum distance accepted from the main entrance of the School of Civil Engineering (Fig. 6a, left). Number of available cars across distances (Fig. 6b, right).

transportation, and "vehicle availability" is initially the equivalent of "frequency" for FFCS systems. From a marketing point of view, an attribute is a characteristic or feature of a product that is thought to appeal to customers. In the public transport sector, the term "service attribute" is commonly used to refer to cleanliness, on-time performance, frequency, availability, comfort and safety, and is the criterion applied to assess customer service quality; "availability" of FFCS means nothing to users if the cars are too far from the user's position to take the decision to travel. The distance limitation for users is thus a key issue when analysing FFCS systems. Another interesting behavioural aspect is how many minutes users would wait if there is currently no car available within the desired distance (radius), and which mode they would switch to if they decide not to use the FFCS system.

In addition to these items (tolerance of walking or waiting and alternative mode of transportation), our survey also included another block of questions to discover the users' attitude when offered fare incentives in exchange for collaboration in promoting smart relocation strategies. The survey sheet included information on the current rates of the Car2go system at the time the survey was carried out $(0.19$ euros/ min; 30 min implied 5.7 euros), bearing in mind that an important percentage of respondents could be non-users. Smart relocation strategies require the collaboration of users, which can only be motivated by fare incentives (free minutes of services in future trips or fare discounts in the current trip). Considering the observed price sensitivity of potential FFCS users in the survey, this would be a cheaper option than operator-based vehicle repositioning to cover areas with high demand and low availability of cars at peak hours. Hermann et al. (2014) introduced four different user-based strategies to apply to FFCS services: incentives to book more distant cars, incentives for a more distant dropoff location, and paid relocation and demand pooling. As these userbased strategies require the implementation of operator apps, Herrmann et al. (2014) called them "smart" relocation strategies. Paid relocation is a strategy in which users are offered specific routes for relocation in addition to a current booking, and are compensated by free minutes or a bonus. Demand pooling is a more complex strategy based on a social network approach in which the users may be invited to share the trip and the trip cost with another user. FFCS customers normally book some time (less than $20 \mathrm{~min}$ ) before starting the trip, and this can be used by the FFCS operator to offer the trip to another user. In any case, these last two strategies require a knowledge of the trip destination. This is the reason survey campaigns that aim to test smart relocation strategies (Herrmann et al., 2014) include a question asking if customers would agree to state their destination at the beginning of the trip

The survey campaign in Madrid was an opportunity to gain a better understanding of how smart user-based relocation strategies should be designed in Spain to increase FFCS demand. Following the Hamburg experience (Hermann et al., 2014), these types of questions were included in the questionnaires with the information on the expectation of car availability and the reliability of the system: the walking distance acceptable to book a car, the period of time the user would wait if there was no car currently available in the desired radius, and alternative transportation mode if the decision to book a car is finally aborted. This latter approach (maximum accepted waiting time) is directly linked to the "reliability of the system", which is a key component of FFCS sys. tems. Table 1 shows the structure of the survey carried out in Madrid and the answer options for the respondents. The answer options were designed to be compared to the Hamburg Car2go results, bearing in mind that most participants $(69.89 \%)$ in the Hamburg survey were in their twenties or thirties (10.75\%). Although the survey methodology in Hamburg was different (96 participants contacted via carsharing forums) and the number of valid respondents (87) was lower in Hamburg than in Madrid (186), we considered Hamburg as a reference point to validate part of our results.

Only $25 \%$ of the Madrid sample had tried a Car2go system, and this percentage was closely related to the place of residence (inside the Car2go service area) and the availability of a private car to access the university. More than $75 \%$ of users live inside the service area and only $40 \%$ have a private car available (not their own) on weekdays. As expected, the availability of a private car for the whole sample (186) was 
low (37\%), making this population group (students, young workers and millennials) a potential market for FFCS systems. The number of users was equally divided between the morning and aftemoon shift, while most respondents declared that they only exceptionally attended libraries at weekends (58\% never visited university libraries at weekends, and $27 \%$ did so "sometimes"). Again as expected, public transportation (bus or/and metro) was the most used (65\%) by respondents to access the faculty and return home, while only $20 \%$ of respondents used their own car on both trips.

Fig, 5 shows the accepted maximum distance to an available car and the accepted maximum waiting time for an available car in a tolerable radius around the user's position. The penetration rate of some relocation strategies is also tested and compared in both cities (Madrid and Hamburg). The same figure shows disaggregated data for Car2go users, and no users are shown for Madrid. In both cases (Madrid and Hamburg), there is a limited accepted distance of $500 \mathrm{~m}$, above which over $80 \%$ of respondents would not rent a FFCS car, although there are different levels of tolerance. In Madrid, a higher percentage (31.52\%) would opt not to use the carsharing system if the vehicle were located at a distance of over $300 \mathrm{~m}$, and this figure drops to $19.35 \%$ in the case of Hamburg. In conclusion, the willingness to accept longer distances is higher in Hamburg than in Madrid, indicating a greater willingness to walk. Similar results are revealed in the analysis of the accepted waiting time, where about $95 \%$ in both cases would not accept a waiting time of over half an hour, although Hamburg respondents showed a higher tolerance towards waiting time: $83.61 \%$ of Madrid respondents would not accept a waiting time of over 15 min., while in Hamburg this percentage drops to $55.32 \%$. When this limit time is reached, users will not use the FFCS system and switch to another transportation mode. In Hamburg, when users were asked which transportation mode they would pick in situations where they decide the FFCS system does not provide sufficient availability, over $80 \%$ listed public transport, and the percentage was similar in Madrid (81.3\%). This finding is consistent with the evidence that the reliability of FFCS is dependent on the existence of a sound public transport network, so a minimum length and service quality is needed in the public transport system to support FFCS demand. The minimum features of a public transport system to warrant a FFCS is a complex topic that is still under research, and could de. termine the implementation of a new FFCS system in a city.

The Madrid survey also shows a slight difference in behaviour between Car2go users and non-users (see Fig. 5). Being a Car2go user conditions the accepted maximum distance and the accepted maximum waiting time, generating higher levels of tolerance for walking and waiting. Confidence in the system is dependent mainly on self-experience, as in any collaborative economic process. This result is interesting from the point of view of strategy for FFCS companies when offering new users their first FFCS experiences (free minutes or fare discounts on the first trips).

In regard to designing user-based repositioning strategies for FFCS systems, only half the potential Madrid users would be willing to accept a more distant car for a $30 \%$ price reduction, whereas this figure was $85.06 \%$ in Hamburg. Again, we found that tolerance for walking is much higher in Hamburg than in Spain, which is probably also related to the tolerance for walking to a public transport station (bus or metro) in both cities; and this is an approach that unquestionably requires further research. Finally, we asked students if they would agree to in dicate their destination at the beginning of the trip and only for this question; Madrid registered higher levels of willingness $(93.99 \%$ versus $88.51 \%$ ) than Hamburg, generating real options for carsharing providers to design alternative strategic destinations. In relation to the type of incentive customers would find more attractive, over $64.29 \%$ of Madrid respondents would be interested in receiving free driving minutes, while $35.71 \%$ voted for a price discount. In Hamburg, most respondents chose the other incentive: the majority $(61 \%)$ voted for a price discount. This fact may be linked to the higher fares for the Car2go services in Hamburg and to the youth of the Car2go system in
Madrid, as people initially experience a so-called "novelty effect" connected with excitement and a desire to travel more often, so receiving more free driving minutes could be a perfect incentive.

Apart from comparing results with the Hamburg study, our research aims to match the availability and reliability of the Car2go system shown in the surveys with the actual physical distribution of the cars ready to book in the area the respondents were located. The area around the faculty in the survey was extracted using the database of systematic sequential observations for the whole campus (October 2016), and the vehicles were counted in each radius considered. Fig. 6 (left) shows the areas of influence in the case study based on the maximum accepted distance $(300,500,700$ and $1000 \mathrm{~m})$ from the main entrance of the School of Civil Engineering. The number of available cars in each area of influence was represented on a graph for the week in October 2016 (Fig. 6, right), indicating that the real availability of cars at a maximum distance of $300 \mathrm{~m}$ or even $500 \mathrm{~m}$ does not meet the potential user expectations revealed by the surveys in this case study. The graph also shows how a slight increase in user tolerance for walking a longer distance (maximum $700 \mathrm{~m}$ ) would increase the offer to at least five vehicles at FFCS peak hour every workday, which reflects a more reliable situation.

To study the link between the distance to destination from the respondent's home location and accepted distance, we considered the groups of users and non-users who live inside the operator's service area. The travel time of trips taken by car $2 \mathrm{go}$ from their neighbourhood to their study centre (School of Civil Engineering) was compared with the time taken for the same trips by public transport. The Google Maps API was used to estimate travel times, in an approach similar to the research of Wang, MacKenzie, and Cui, (2017), but with a limited trip sample ( 36 users and 73 non-users). As we only asked the students to provide their home postcode, the centre of gravity of the postcode polygons is considered the origin of trips, and the School of Civil Engineering the destination. Fig. 7 shows the location of the users' (left) and non-users' (right) address considering their postcode. Postcodes inside the car2go service area (marked with a blue line) were selected for this analysis to compare trips that can be done either by car2go or public transportation systems. Both travel times, and the average admissible walking distance (to available Car2go cars) stated by users who live in each postcode are shown in Table 2 . The results reveal that the car $2 \mathrm{go}$ travel time is $61 \%$ of the travel time on public transit; that is students who go to the School of Civil Engineering in a FFCS vehicle take an average of $39 \%$ less time compared to public transportation, in fluid traffic conditions. To this should be added the walking travel time from the students' home to the underground station or bus stop where they take the transportation mode, and the waiting time. According to our estimation, the average walking time from the points considered to the stations is seven minutes, and the average waiting time is three minutes, which would increase the time in public transportation by ten minutes. It should be noted that most of these routes would theoretically be done by underground, which has a frequency of between four and six minutes, thus reducing the average waiting time. The time taken by the user to walk to the reserved car must be added to the car2go travel time. In all cases, the average admissible distance stated by users living in each postcode does not exceed $650 \mathrm{~m}$, equivalent to seven minutes' walking. An analysis of the postcodes with the least difference between travel time in car2go and public transportation shows that they are fairly close to the School of Civil Engineering, but are poorly connected by underground, requiring students to take urban buses which are more susceptible to traffic conditions. The analysis of FFCS travel times and the operation limitation require further research in order to understand the users' dynamic in the transport system.

Understanding the characteristics and variability of walking access to FFCS vehicles, as with any public transportation mode, is a key issue in analysing demand. In our research, pedestrian accessibility distance has been estimated using radial catchments, which involves some inaccuracies, as paths and topographical barriers affect the real walkable 


\section{ANÁLISIS DEL IMPACTO DE LOS SISTEMAS DE FREE-FLOATING CARSHARING EN ENTORNOS URBANOS UTILIZANDO DATOS WEB: APLICACIÓN A LA CIUDAD DE MADRID}

M. Ampudia-Renuncio et ai.

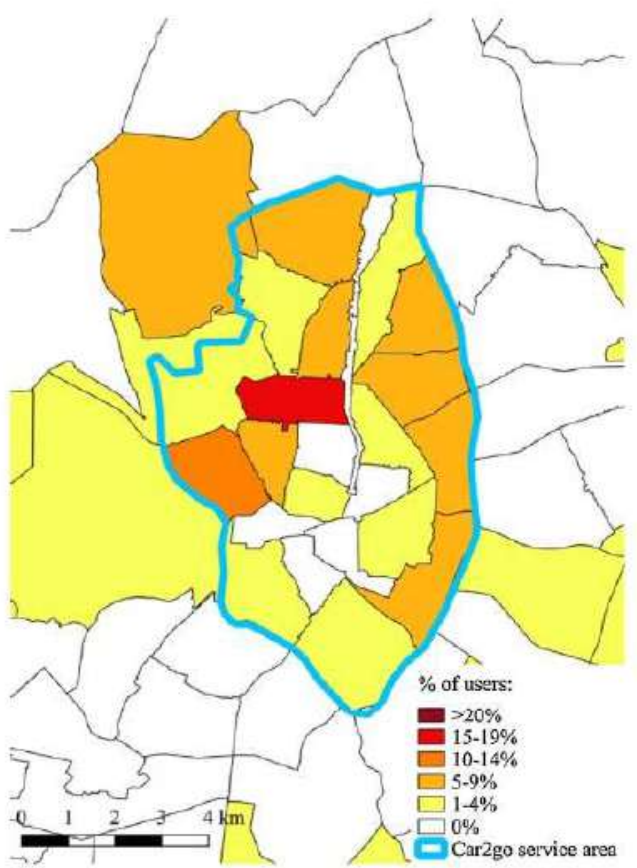

Sustainable Cities and Soctery 43 (2018) $462-475$

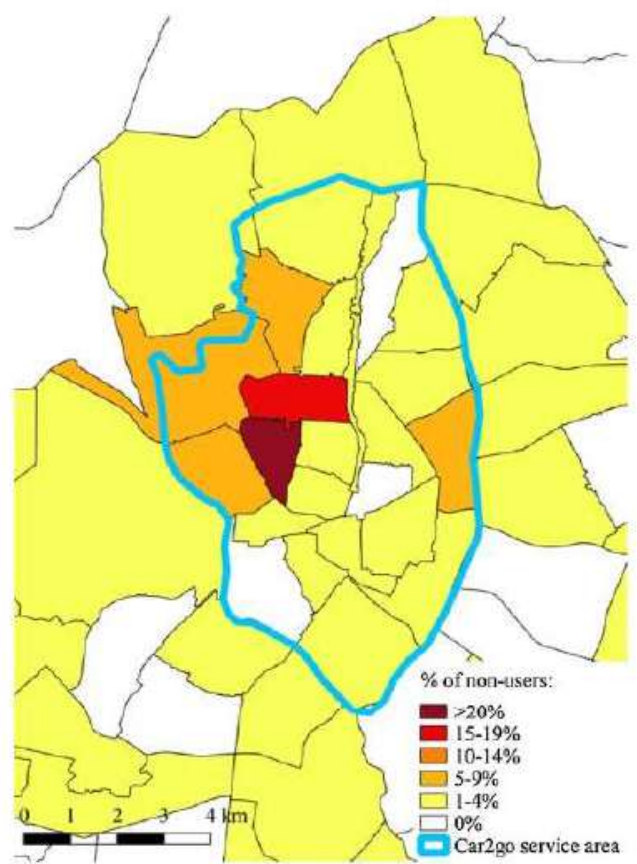

Fig. 7. Loeation of the FFCS users' (left) and non-users' (right) address considering their postcode. The blue line indicates the boundaries of car2go service area.

distance. The existing literature on walking indicates that trip purpose and the "built environment" are among the potential influences on the characteristics and variability of the walking distance as an access mode to public transport. Many authors (Cervero, Sarmiento, Jacoby, Gomez,
\& Neiman, 2009; Handy, Boamet, Ewing, \& Killingsworth, 2002; and Frumkin, Frank, \& Jackson, 2004) consider permeability, footpaths, lighting, security, density, and mixed land use as characteristics of the built environment which can influence walking as both a transport

Table 2

Comparison of travel times in car2go and public transportation from each postcode within the Car2go service area to the School of Civil Engineering. The proportion of users and non-users of those living inside the service area is shown, and the average admissible walking distance to an available FFCS vehicle.

\begin{tabular}{|c|c|c|c|c|c|c|c|}
\hline \multirow[t]{2}{*}{ Postcode } & \multicolumn{2}{|c|}{ FFCS Users } & \multicolumn{2}{|l|}{ FFCS Non-users } & \multicolumn{2}{|c|}{ Travel time (min) } & \multirow[t]{2}{*}{ VoCar 2 go travel time over PT } \\
\hline & $\%$ users & Average AWD & $\%$ of non-users & Average AWD & PT & car2go & \\
\hline 28002 & $6 \%$ & 400 & $3 \%$ & 400 & 24 & 15 & $63 \%$ \\
\hline 28003 & 1796 & 400 & $15 \%$ & 332 & 11 & 5 & $45 \%$ \\
\hline 28004 & $3 \%$ & 150 & $3 \%$ & 150 & 23 & 14 & $61 \%$ \\
\hline 28005 & $3 \%$ & 400 & - & - & 31 & 11 & $35 \%$ \\
\hline 28006 & $3 \%$ & 150 & $1 \%$ & 650 & 15 & 12 & $80 \%$ \\
\hline 28007 & $6 \%$ & 400 & $4 \%$ & 483 & 23 & 20 & $87 \%$ \\
\hline 28008 & $11 \%$ & 400 & $7 \%$ & 200 & 10 & 6 & $60 \%$ \\
\hline \multirow{2}{*}{28009} & $3 \%$ & 400 & $4 \%$ & 317 & 24 & 19 & $79 \%$ \\
\hline & - & - & $3 \%$ & 525 & 20 & 8 & $40 \%$ \\
\hline 28012 & - & - & $1 \%$ & 150 & 23 & 18 & $78 \%$ \\
\hline 28013 & - & - & $1 \%$ & 400 & 16 & 11 & $69 \%$ \\
\hline 28014 & - & - & $1 \%$ & 400 & 31 & 14 & $45 \%$ \\
\hline 28015 & $8 \%$ & 317 & $26 \%$ & 372 & 11 & 7 & $64 \%$ \\
\hline 28016 & $6 \%$ & 525 & $3 \%$ & 400 & 21 & 16 & $76 \%$ \\
\hline 28020 & $8 \%$ & 400 & $41 \%$ & 317 & 19 & 12 & $63 \%$ \\
\hline 28028 & $6 \%$ & 400 & $7 \%$ & 350 & 20 & 16 & $80 \%$ \\
\hline 28029 & $6 \%$ & 400 & $3 \%$ & 400 & 33 & 9 & $27 \%$ \\
\hline 28030 & $3 \%$ & 650 & - & - & 34 & 22 & $65 \%$ \\
\hline 28035 & $3 \%$ & 150 & $1 \%$ & 650 & 16 & 7 & $44 \%$ \\
\hline 28036 & $3 \%$ & 150 & - & - & 22 & 16 & $73 \%$ \\
\hline 28039 & $3 \%$ & 400 & $5 \%$ & 338 & 14 & 9 & $64 \%$ \\
\hline 28040 & $3 \%$ & 150 & $4 \%$ & 400 & 10 & 4 & $40 \%$ \\
\hline 28045 & $3 \%$ & 400 & $1 \%$ & 150 & 31 & 18 & $58 \%$ \\
\hline 28046 & - & - & $1 \%$ & 400 & 20 & 12 & $60 \%$ \\
\hline Total & & & & & & & $61 \%$ \\
\hline
\end{tabular}

AWD: Admissible walking distance declared at surveys.

PT: Public transportation. 
mode and an access mode to public transport. FFCS is a new type of public transportation that needs a minimum walking access distance. No FFCS studies have been published so far using this approach and this research in Madrid has demonstrated that the limits of acceptable distance are a key component of the reliability of FFCS systems.

\section{Conclusions and Policy Recommendations}

With the increasing demand for new FFCS systems, there is a consensus among scientists that the valuable results from existing carsharing research cannot be transferred to FFCS. The positive impacts of FFCS on public transportation are not sufficiently clear, and policymakers' role in ensuring privileged access by FFCS to on-street parking is a key issue for their future development. Despite this, more research is required into this new mode of transportation, and there should be a more specific focus on user behaviour and perception of service quality. This paper aims to fill this gap by taking advantage of the implementation of the first FFCS in Spain, analysing a limited study area and working on a population group with high potential to use FFCS systems.

Sequential observations of car availability in the study area have revealed maximums (for workdays) after the morning peak congestion in the city, which is reasonable in view of the fact that FFCS charge by minute, so congestion makes the system less competitive. Students have some flexibility in their work schedule (in common with self-employed workers, housewives and teleworkers); this profile is needed to avoid congestion, and is one of the strengths for potential demand for FFCS. The parking space inventory and the location of public transport stations (metro and urban bus) were found to be key data for understanding the geographical distribution of the available FFCS vehicles obtained through the operators' web observations. From a policy point of view, the municipal government (through parking regulation and measures to promote public transport) can allow the FFCS to reach their customers or to prevent them from doing so, as FFCS services depend on privileged access to on-street space (uncongested streets, free or cheap parking).

The survey campaign provided important findings on the reliability of the new FFCS system, especially when compared to the Hamburg results. As in any public transportation mode, reliability is linked to frequency and punctuality, which in terms of FFCS means the acceptable walking distance to book a car, the period of time the user must wait if there is currently no car available in the desired radius, and the alternative transportation mode if the decision to book a car is finally aborted. Hamburg and Madrid showed the same range of responses: there is an accepted limit distance of $500 \mathrm{~m}$, above which over $80 \%$ of respondents in both cases would not rent a car, about $95 \%$ would not accept a waiting time of more than half an hour. Similar percentages are also seen in both cities when respondents are asked about alternative transport if the FFCS booking is aborted: $80 \%$ listed public transport, revealing that the FFCS system cannot be successfully implemented in cities without a minimum quality of service in the public transportation network. The difference between Hamburg and Madrid is mainly the higher tolerance of walking and waiting in Hamburg, in the range of between 300 and $500 \mathrm{~m}$. Further research is needed into the past experience of FFCS users as public transport customers. In all likelihood, when new FFCS users transfer from the traditional public transport system, their tolerance of walking or waiting is higher than if they come directly from the private car. In our case study, the real availability of FFCS vehicles reveals than an increase in the user tol. erance of walking a longer distance (maximum $700 \mathrm{~m}$ ) would extend the offer to at least 5 vehicles at FFCS peak hour every workday, up $70 \%$ compared to the equivalent availability at a maximum distance of $500 \mathrm{~m}$. The declared level of acceptance of future smart relocation strategies is good in both cities, but still depends on the limits of the walking distance, even if incentives are given (fare reductions or free minutes of driving). Acceptable distance and time limits therefore emerge as a key component of the reliability of FFCS systems, and require further research.

The authors of this paper acknowledge that the policy re commendations derived from this study are constrained by the number of similar experiences and the sample size (which only focuses on a university student profile). Nevertheless, some of these findings cannot be ignored by FFCS operating companies and municipal governments as a first step towards the discussion of the best policies to incorporate these new collaborative transport modes sustainably into our urban transport systems. From the scientific standpoint, it is essential to ensure that the arrival of these new carsharing modes leads to more sustainable cities and complements public transport. This will depend on the changes in people's attitudes to urban mobility in coming decades, with particular emphasis on tolerance to walking (the most sustainable mode of transportation) as a key component not only for the new FFCS systems but for any public transportation option.

\section{References}

5r-Bureau de Recherche (2014). One-way carsharing Which alternative in private car? The use study of Amolib' in Paris264.

6t-Bureau de Rechenche (2013). National Survey on Carsharing - Carsharing as a urigger of a aiternative mobility to the persond car. Report end surmeary(Accessed 15 June 2018) arailable at the addresshtips://6-t.co/en/national-surrey-carsharing-france-2016/.

Ayuntamiento de Madrid (2005) Ordenanea de Movilidad para la Ciudad de Madrid. Acuerdo Pleno de 26 de septiembre 2005. BOCM núm. 247 de 17 octubre 2005. Modificada por Acuerdo Pleno de 27 de junio de 2012. BOCM núm. 154 de 29 de junio de 2012

Ayurtamiento de Madrid (2012) Ordenanza Fiscal Reguladora de la Tasa por Estacionamiento de Vehículos en Determinadas zonas de la Capital y de delimitación de la Zona de Estacionamiento Regulado. Acuerdo Pleno de 9 de octubre 2001 Modificada por Acuerdo Pleno de 21 de diciembre de 2012. BOCM núm. 309 de 28 de diciembre de 2012.

Becker, H. Ciari, F. \& Axhausen, K. W. (2017), Comparing car sharing schemes in Switzerland User groups and usage patterns, Transportatian Research Part A, policy and Proctice, $97,17-29$.

BMW blog (2011). DriveNow: BMW and Sixt Joint venure for premium car sharing LBigg past]. March 21 Retrieved fromhtups/ www brmblog, conn/2011/03/21/bm wand

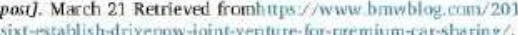

BMW blog (2016). BMW lauriches Car Sharing service Read Now in Seutte lblog post. Apri 8 Retrieved fromhttps://www.bmwblog.com/2016/04/08/bmw lasunches-carSharing service reachinow scattle.

BMW blog (2018). BMW buys out Sixt, becomes sole owner of DriveNow platform [Blog post]. January 29 Retrieved fromhtips// www, bmw blog, com/2018/01/29/bmw -buys sixi drivenow-becomes sole-owner/.

Car2go blog (2018)]. We are three milition! [Blog post]. February 7 Retrieved fromhit ps:? blog.car $2 \mathrm{go} . c 0 \mathrm{~m} / 2018 / 02 / 07 /$ we-are-3-million/.

Car2go blog (2018b). Daimler and BMW - The parent companies of car2go and DriveNow Signed an agreement to form a joint venture [Blog past]. March 28 Retrieved

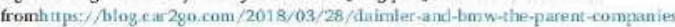

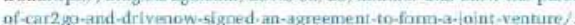

Cerverco, R. Sarmiento O. Jacoby, F. Gomer, L. F. \& Neiman, A, (2009), Influences of

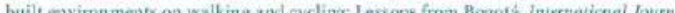

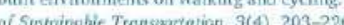

Ciari, F., Beek, B, \& Balmer, M. (2014). Modeling station-based and free floating car sharing densand test case study for Berlin. Tratsportation Research Record. 2416(1), sharing

Ciuri, F, Balac, M., \& Balmer, M (2015). Modelling the effect of different pricing sehemet on free flaating carshuning travel denaind a test ease for Zurich, Switzertund. Transportation, 42(3), 413-433.

Cohen, A., \& Shaheen, S. (2016). Planning for shared mability. PAS repart 583 American Planning Acsociation 103 July, 2015 ,

Delbosc, A. (2017). A tale of two millennials Journal of Transport and Land Use, 10(1), 903-910

Dempsey, A. (2016). Why are millesnials buying fewer cars? Doctoral dissertationThe Ohin State University.

DriveNow blog (2017). DriveNow celebrares its 1 millionth customerl [Blog post]. October 10 Retrieved fromhittps:/ www drive-now com/gb/en/blog/one-million-customers.

Fan, W., Machemehl, R. B., \& Lowines, N. E. (2008), Carsharing: Dynamic decision-making problem for yehicle allocation. Transportation Research Record Journal of the Transportation Research Boand, 2063, 97-104.

Firnkorn, J. (2012). Trinnzulation of two methods measuring the impacts of a freeflosting cersharing system in Germany. Transportation Research Port $A$, Poicy and practice, $46(10), 1645-1672$.

Firnkorn. i. \& Muller, M. 12012). Selling mobility instead of cars New business strategies of automakers and the impact on private vehicle holding. Business Strategy and the Enironreats 21(4), 264-280.

Firnkorn, I., \& Müller, M. (2011) What will be the environmental effects of new FreeFioating Car-Sharing systems? The ease of car2 ga in Ulm Frolagicat Fconumics $70(8)$ 1519-1528. 


\section{ANÁLISIS DEL IMPACTO DE LOS SISTEMAS DE FREE-FLOATING CARSHARING EN ENTORNOS URBANOS UTILIZANDO DATOS WEB: APLICACIÓN A LA CIUDAD DE MADRID}

Frumkin, H. Frank, 1, \& Jackson, R. (2004) Urban giraud and pubüc bealth: Desigging pionning and butlding for heokthy communitiex. Island Press.

Guirao, B. Garcia. Pastor, A. Lóper, M. F., Achs, C., \& Comendador, 1. (2015). New QR suryey methodologies to annlyze ueer perception of service cuality in public trang port: The experience of Madrid. Journal of Public Transportation. 18(3), 71-88.

Guirao, B. Garcia-Pastor, A., \& L.6pez-Lambas, M. E. (2016). The impertance of service quality uttributes in public transportation Narrowing the gap between scientific re search and practitioners' needs. Transport Pobicy, 49, 68-77.

Haefoli, U., Matti, D., Schreyer, C., \& Maibach, M. (2006), Evaluation carsharing. Bern Federal Department of the Environment, Transport. Energy and Communications.

Handy, S., Boamet, M, Eving, R., \& Killin gsworth, R. (2002). How the built environment affects physical activities: Views from urban planning. American, Iotamai of Preytntive Medicine, 23(2), 54-73:

Heilig, M, Mallig, N, Schrìder, O. Kagertianer, M, \& Vortisch, P. (2017) Implementation of free-floating and station-based carsharing in an agent-based trave demand model. Travel Behcrionir \& Sacleny, 12, 151-158

Hermann, S., Schuke, F., \& Yoß, S. (2014). Increusing acoptance of Frow-fouting cur

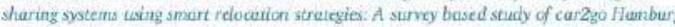

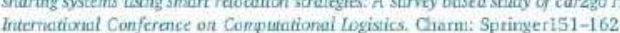

Hwang, J, \& Griffiths, M. A (2017). Share more, drive less: Millennials value perception and behaviorul intent in using collaborative conamption services. The Journal of and behavioml intent in using collab

Hyundai Motor Europe (2017). Hyunda electric car sharing starting in Amsterdant with 100 cars. Oeto ber 05 Retrieved fromhttps://www hyundainews/es//model-news hyvondai-electric-car-sharing starting -in-amserdam-with-100-cars .

3orge, D., Correia, G., \& Bamhart, C. (2012). Testing the validity of the MatP approsech for locating earsharing station in one-way systems. Procedia-Social and Behavioral Sciences, 54, 138-148.

Jorge, D, Molnar, G , \& de Almeichi Correia, G. H. (2015). Trip pricing of one-way stationbased carshar ing networks with zone and time of day price variations. Transportain Research Part B Methodoiogical 81, 461-482.

Rek, A. G. Chex, R. L., \& Chor, M. L. (2006). Relocation simulation model for meiltiple. station shared-use vehicle systems. Trunsportution Reseerch Recond, 1986(1), 81-88.

Kek, A. G. Cheu, R. L, Meng, O. \& Fung, C. H. (2009), A decision support system fir vehicle relocation operations in carshaning systems. Trusportation Resomrch Part Logisties and Transportation Review, 45(1), 142-158.

Kopp, J., Gerike, A., \& Axhausen, K. W. (2015), Do sharing people behave differently? Ar empirical evaluation of the distinc tive mobility pattems of free-floating car-sharing members, Transportation, 42(3), 440-469.

Kortum, K., Schönduwe, R., Stolte, B., \& Bock, B. (2010). Free-Floating Carsharing: City. specific growth nates and success factors, Trenspercution Research. Procedia, 19 328-390.

Le Vine, S_Adamou, O. \& Polak, J. W. (2014). Predtering new forms of activity/mobility paterns enabled by shared-mobility services thmutgh a needs.based stated response method: Case study of grocery shopping. Tronsport Policy, 32, 60-68.

Loose. W. $(2010)$ The stare of eurupean car-sharing. Project moma final repart $d 2$.

Martin, E., ES Shaheen, S. (2010), Greenhouse gave emission impacts of carsharing in North America. IEEE Transactions on Intelligent Trunsporiation Systems, 12(4), 1074-1086.

Martin, E., \& Shaheen, S. (2016). Impacts of Cur2go or velatic ownership, modal shift, velache mules traveled, and greenhouse gas emissions; An analystis of five North American cities. UC
Berkeley: Transportation Surtainubility Rese:arch Center.

Millaxd-Ball, M. Murray, G. Ter Schure J., Fox, C. \& Berkhardt, J. (2005) Car-sharinge Where and haw ir succerde Na Transit comperntive rescerch pmgram reporr 108 Transportation Research Bourd.

Mont, $O$. (2004). Institutionalisation of sustainable consumption patterns based on shared use. Ecological Economics, $50(1-2), 135-153$.

Mont, O., \& Plerys, A. $(2003)$. Suatuinable consumption urogress: should we be proud of ahrmed? Joturnal of Cleaner Production, 16[4), 531-537.

Mont, 0., \& Tukker, A. (2006). Procuet-Service Systems Reviewing achievements and fefining the resesrch agenda. Joumal of Cleaner Production, 14[177), 1451-1454.

vieller, J., Schmoeller, S, \& Glesel, F. (2015). Identifying users and use of (eletric: Free.flesting earsharing in Eerlin and Munich. In intelligent Transpartericn Sysernis (TTSC), 2015 TEFE 18it Intemarianal CAnference an. 2558-2573.

Vair, R., \& Miller-Hooks, E (2010). Fleet management for veth icle sturing operations, Frangportation Stience, 45(4), 52,4-540.

Niels, T. \& Bogenberges, K. (2017). Booking behwior of free-floating carsharing users Empirical analysis of mobile phone app and booking date focusing on battery electric velicles. Transportation Researdi Record Joumal of the Trensportation Researth Boend. $2650,123-132$.

PSA Group (2017). Nen mobility: PSA presents its mability services. November 27 Retrieved fromhitps://www groupe psa.eom/en/story/la-liberte de mouvement'

Raviv, T., Tzur, M. \& Forma, I. A. (2013). Static repositioning in a bike-sharing system Models and solution approsehes. EURO Journal on Thansportation and Lagistics, 2(3) $187-229$.

Schaefers, I. (2013). Exploring carsharing usage motivest A hierarchical meansend chain analysis. Tronsportation Research Part A, Poticy and Practice, 47, 69-77.

Schulte, F, Bc Vo B, S. (2015). Decision support for environmental -friendly vehicle re locations in fres floating car sharing systems The case of car 2 ga pracedia CIRP, 30 , $275-280$

Shaheen, S., \& Cohen, P. (2007). Growth in world wide carsharing: an intermational comparison. Transportation Research Record, 1992(1), 81-89.

Shatheen, S. Ouhen, A, \& Chung, M. (2009), North American carsharing: 10-yeasr retrospective. Trutspartation Rescunh Record, 2110(13,35-44.

Song. D., \& Doang, J. (2011). Effectiveness of an empty container repositioning policy with flexible destination ports. Transport Poilizy, $t 8(1), 92-101$.

Stocker, A., Lazunus, J., Becker, S., \& Shaheen, S (2016). North american Colicge/University

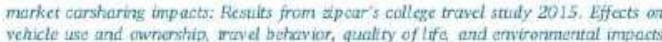
transportation sustainability research conter. Working paper. September 2016.

Wang, $\bar{X}$, Mackenvie, D., \& Cui, Z. (2017), Complement or competitor? Comparing car2ge and transit travel times, prices, and usage patterns in seattle. Transportation Reseurch Board of Annual Meeting, 589, 17.

Wielinski, G, Trépanier, M, \& Morency, C. (2015) What abott free-floating carsharing? A look at the Montreal, Canads, ease. Transportanior Research Recond, 2536, 28-36. Wielinski, G. Trepanier, M. \& Morency, C. (2017) Flectric and hybrid car use in a fresfloating carsharing system. Internationd .Joumei of Sustainable Trangioriotion. 11(3). $161-169$

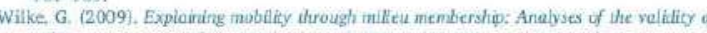
tiliieu concepts using the exumple of car-sharing. Subject-Orionted approuches tw trunsport. hst. Für Reatuplaring 24-39. 


\section{IV.3. ARTÍCULO II: UNDERSTANDING THE SPATIAL DISTRIBUTION OF FREE-FLOATING CARSHARING IN CITIES: ANALYSIS OF THE NEW MADRID EXPERIENCE THROUGH A WEB-BASED PLATFORM.}

Cities 98 (2020) 102593

Contents lists available at ScienceDirect

Cities

journal homepage: www.elsevier.com/locate/cities

Understanding the spatial distribution of free-floating carsharing in cities: Analysis of the new Madrid experience through a web-based platform

María Ampudia-Renuncio $^{a}$, Begoña Guirao ${ }^{\mathrm{a}, *}$, Rafael Molina-Sánchez ${ }^{a}$, Cristina Engel de Álvarez

"Departamento de Ingenieria del Transporte, Territorio y Urbanismo, ETSI Caminos, Canales y Puertos, Universidad Politécnica de Madrid, Avda. Profesor Aranguren, s/n, 28040 Madrid, Spain

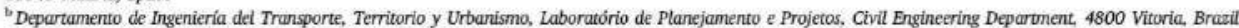

A B S T R A C T

In recent years the sharing economy has become established in different modes in the urban transport system, and claims to be reducing the number of cars and contributing to lower traffic pollution. Free-floating carsharing (FFCS) is a new and more flexible type of carsharing that is driving the growth of carsharing markets around the world. While there is a very extensive literature on traditional carsharing, more research needs to be done on the new FFCS trip profile in order to estimate its spillover effects on the urban transportation system. As FFCS systems are based on ICTs, new web-based methodologies (instead of traditional surveys) are the best approach to analyse them.

This paper contributes to the existing literature with a spatial evaluation of the FFCS trip profile, obtaining a temporal distribution of the main flows throughout the FFCS service area. The added value of this research is that it provides the first spatial analysis of a FFCS system in Spain using rental data collected from the operators' websites. The results clearly show the prevalence of the short-distance FFCS trip that is faster than available public transport and whose origin and destination are closely dependent on parking availability.

\section{Introduction}

Carsharing has migrated in the last decade from the traditional station-based format to a free-floating system, while maintaining the original advantages of the carsharing approach: "a fleet of cars can be shared by several users, who can drive a car when they need it, without having to own one" (Ciari, Bock, \& Balmer, 2014). FFCS allows members to pick up a car from the street and return it within a specified area of the city, usually called "the service zone". FFCS users are referred to as "members" as they must be logged on to the FFCS operating companies' website before using this rental service. The emergence of this new generation of carsharing has been enabled by the population's massive use of ICTs (information and communication technologies), together with the boom in the sharing economy worldwide in all activity sectors. Smartphone apps allow FFCS company members simply to search and book a vehicle close to their current location in the city inside a geofence (a virtual service zone defined by the company), in which a person can rent and drop off cars near their demand points (final origin or destination of the trip). Prices for FFCS services are usually quite competitive with other urban transport systems, compared to renting a car with a driver (ride-hailing services) or traditional taxi services.
The first FFCS was implemented in Europe in October 2008 by the company car2go (a Daimler AG subsidiary), which launched the first fleet in the German city of Ulm. The FFCS market has so far been dominated by two major operators worldwide (Europe, North America and Asia), car2go and DriveNow/ReachNow, which are closely linked to the car manufacturing industry. Globally car2go provides service in 25 cities and DriveNow/ReachNow in 15. There are also other smaller companies that operate in just one city or country (Habibi et al., 2017), and in recent years other major car manufacturers have also created their own competing FFCS solutions, such as the French PSA Group and the South Korean Hyundai Motor Company. A study comparing 22 cities in Europe and North America (Habibi et al., 2017) recently positioned Madrid and Hamburg as having some of the highest utilisation rates for FFCS vehicles, as estimated by the total time (minutes) all cars are used each day divided by how many minutes they can potentially be driven. Madrid has a long public transport tradition, and - like other European cities - has seen a huge rise in carsharing systems, in which FFCS was only implemented in 2015.

The rapid growth of demand for FFCS in recent years (Herrmann. Schulte, \& Voß., 2014; Wielinski, Trépanier, \& Morency, 2015) is associated to the fact that it is a clearly one-way, non-station-based carsharing system that offers its members greater flexibility and is an

- Corresponding author at: Departamento de Ingenieria del Transporte, Territorio y Urbanismo, ETSI Caminos, Canales y Puertos, Universidad Politécnica de Madrid, Avda. Profesor Aranguren, s/n, 28040 Madrid, Spain.

E-mail addresses: m.ampudia@alnmnos.upm.es (M. Ampudia-Renuncio), begona.guirao@upm.es (B. Guirao), rafael.molina@upm.es (R. Molina-Sánchez), cristina.engel@ufes.br (C. Engel de Álvarez). 


\section{ANÁLISIS DEL IMPACTO DE LOS SISTEMAS DE FREE-FLOATING CARSHARING EN ENTORNOS URBANOS UTILIZANDO DATOS WEB: APLICACIÓN A LA CIUDAD DE MADRID}

economic alternative to mobility in urban areas, which is why it attracts a wider set of drivers (Heilig, Mallig, Schröder, Kagerbauer, \& Vortisch, 2017; Kopp, Gerike, \& Axhausen, 2015). Although flexibility is therefore the differentiating feature of FFCS systems and the main attractor for potential demand, this flexibility is closely dependent on the availability of the FFCS cars to rent. If members frequently experience non-available FFCS cars near their demand points, they will cease to perceive FFCS as a substitute transport mode for other more reliable modes in urban areas. The customers' experience (their reliance on the system) conditions the FFCS service quality. Even when they have already rented a car on one trip, the web platform does not guarantee finding another car on the trip home or to their next activity. The reliability and quality of a FFCS service depends on good spatial availability at all times (Niels \& Bogenberger, 2017), and this is not only a function of the number of vehicles provided by the FFCS company in a city, but also of the number of street parking slots and privileged access to street space (cheap or free parking, uncongested streets). This privileged access to street space (favourable parking regulations) can be promoted or deterred by urban policymakers, which is why some authors such as Le Vine, Adamou, and Polak (2014) have identified policymakers and transport planners as "gatekeepers" of these new systems (Ampudia-Renuncio, Guirao, \& Molina-Sánchez, 2018; Le Vine et al., 2014). Some municipalities (Sprei, 2018) such as San Francisco have refused to provide preferential parking space to FFCS services, arguing that the drawbacks of FFCS outweigh the potential benefits. These drawbacks usually concern the induction of more vehicle-km by substituting public transport.

The first step to a better knowledge of how these new systems impact the urban transportation network is to determine the spatial distribution of FFCS flows per origin-destination in order to estimate scientifically the drawbacks and potential benefits of the system. Until now, little research on FFCS has been devoted to the scientific analysis of real flows using revealed web-based data. Most of the literature on FFCS relies on a wide variety of survey-based methodologies (Martin \& Shaheen, 2016) and simulations (Ciari et al., 2014; Firnkorn, 2012; Firnkorn \& Müller, 2011; Kopp et al., 2015), which still leaves many questions unanswered, such as whether these systems increase the overall vehicle-km travelled (VKT) and hence negatively affect traditional public transport.

Revealed web-based data focus on the current position of available FFCS cars (at least when parked and not booked). The vehicle supplies its position to the operator and is publicly available through web pages (or smartphone apps) to enable the user to find and book unoccupied vehicles. The user is also given the vehicle identity number in the reservation process, so the vehicle's movements can be tracked and an origin-destination matrix can be scientifically estimated. This is not easy, as it is based on certain hypotheses and an interpretation of the company's operation in terms of vehicle booking times and recharging operations. Of course, the companies operating the FFCS systems control the entire database of car movements (real origin-destination matrix) and user profiles, but are reluctant to share this information with the scientific community for mainly commercial and competitive motives. There is a second reason: if the analysis of FFCS flows leads to a decrease in the use of public transport or an increase in pollution, local governments could enact regulations against FFCS carsharing, for example by limiting their privileged access to street space (no free or cheap parking, congested streets). There is therefore a scientific need to analyse and verify FFCS flows independently of the companies' operating data. In fact, the cooperation between FFCS companies and councils (as in the city of Munich) is very slow in developing.

This paper contributes to the existing literature with a territorial evaluation of the FFCS trip profile for the city of Madrid, obtaining the spatial distribution of the main flows through the FFCS service area. From an international perspective, the contribution to the new FFCS body of research is focused on the web-based analysis of the FFCS flows, providing criteria based on the identification of trips and describing the anomalies that can be found during the process. From the urban planning view, the added value of this research is that it provides the first analysis of the impacts of a FFCS system in Madrid using web-based data (from November 28, 2017 to April 12, 2018) and compares the main FFCS flows in the city and the public transport services offered at the urban level. The article has been divided into the following parts in order to describe the research as a whole: introduction (Section 1); a review of the literature on FFCS (Section 2); a depiction of the city where the research was carried out (Section 3); a description of the data and methodology (including data sources, design of the web based platform and criteria used for the identification of FFCS trips) in c Section 4; analysis process and a detailed assessment of the main results (Section 5); and finally, the presentation of the most important conclusions and policy recommendations (Section 6).

\section{Evolution in the analysis of the new free-floating carsharing systems}

The new FFCS systems had their origins in station-based carsharing, yet the scientific community has refused to directly transfer the results of the extensive literature on station-based systems to the FFCS (Firnkorn \& Müller, 2011). The environmental benefits and changes in user behaviour derived from traditional station-based carsharing were clear in the urban context (Haefeli, Matti, Schreyer, \& Maibach, 2006; Loose, 2010; Martin \& Shaheen, 2011; Shaheen \& Cohen, 2007; Shaheen, Cohen, \& Chung, 2009; Wilke, 2009), and the effects included a reduction in total $\mathrm{CO}_{2}$ emissions and in the average number of vehicles per household, and even in vehicle-kilometres travelled individually. However, FFCS emerged in a different scenario, with a different price structure and higher flexibility, and some authors have pointed out (Becker, Ciari, \& Axhausen, 2017; Kopp et al., 2015) that this new pool of users would probably not have been attracted by the previous station-based model.

The concept of FFCS as a "product service" in the mobility market (Mobility as a Service), promoted by traditional car manufacturing firms, modifies the approach used to analyse this disruptive type of mobility (Firnkorn \& Muller, 2012). The emergence of FFCS is supported on car firms' idea that services in combination with products could bring higher profits than products alone (car sales for individuals, car ownership). The rapid growth of the electric vehicle market has also affected the new FFCS systems, and in some European cities (such as Madrid and Amsterdam) FFCS companies have only electric cars in their fleet. Customers consequently become initiated in the experience of driving electric vehicles (which is also a primary target for car manufacturing firms), in addition to producing positive environmental impacts in cities. However, Madrid and Amsterdam are exceptions (Sprei et al., 2017) and the other study cases such as Berlin, Stockholm, Vienna or Munich have a mix of FFCS vehicles (fossil fuel-powered and electric vehicles), and car charging is resolved by a wide variety of methods. The charging logistics are quite important for the benefits and market of a FFCS company, and in the case of electric vehicles, can reduce so-called "range anxiety" for the customer (Wielinski et al., 2017), especially when the company fully assumes the electric charging process.

The first studies assessing the concept of FFCS as a mobility product were based on customer surveys and sought to analyse their attitude towards car ownership after trying FFCS services, and particularly their willingness to forego a private car purchase in the future (Martin \& Shaheen, 2016; Namazu \& Dowlatabadi, 2018; Wang et al., 2017). However, as some authors have pointed out (Sprei, 2018), users who give up vehicle ownership usually have other reasons rather than simply joining a FFCS system, such as a new job, an increase in the cost of car maintenance or insurance, or an old car that has broken down (Katzev, 2003). Attitudes to car ownership are complex to analyse, although members of carsharing systems tend to have a low sense of vehicle ownership and a more utilitarian view of mobility (Bardhi \& 
Eckhardt, 2012; Lamberton \& Rose, 2012; Prettenthaler \& Steininger, 1999). Assessing the impact of FFCS on car ownership also implies analysing the disadvantages of owning a vehicle, such as finding parking, and maintenance and repair costs. Stricter parking regulations and fees depend on each city council and this is one reason for the difficulty in transferring results (on attitudes to car ownership) from one country to another, and even from one city to another in the same country.

The use of surveys to define the FFCS user profile poses many problems as it is very difficult to obtain a representative sample of users. According to Müller, Correia, and Bogenberger (2017), there is no way to guarantee that the selected sample size will maintain the same proportions as the customer groups and hence their total number of trips. Surveys must be used as an additional tool, especially in studies on FFCS demand. Until now, the literature has shown that surveys have been used in a complementary way together with simulation methods, and in a few study cases with real data provided directly by FFCS companies (Müller et al., 2017; Schmöller, Weikl, Müller, \& Bogenberger, 2015).

The first studies on the impacts of FFCS were concentrated in German cities (the cradle of FFCS systems) and aimed to estimate the eco-sustainability of this disruptive mode of transport. Firnkorn and Müller (2011) assessed the environmental benefits of the FFCS operating system (fuel-powered Car2go) for the city of Ulm by calculating three scenarios. Based on a quantitative survey, the forecast took into account the five-year period after the launch of Car2go (2009), and obtained a $\mathrm{CO} 2$ reduction per average Car2go member. The survey included some ownership questions, and more than a quarter of the respondents stated that if Car2go were permanently available, they might forgo a car purchase and use Car2go instead. The result obtained on vehicle reduction in Ulm (Car2go) was verified by making a comparison until 2014 with the official car registration figures. In a later study, Firnkorn (2012) validated these results for Ulm using triangulation with retrospective data. Berlin has been also the scenario of many studies on FFCS systems. One of the first questions studied when these systems arrived on the scene was how they would affect existing station-based car-sharing systems. Ciari et al. (2014) compared fuelpowered FFCS demand in Berlin to the theoretical demand for stationbased carsharing using MATSim, an agent-based simulation model software. The main result of the study was the apparent complementarity of FFCS and station-based systems, together with the high potential of the option to further extend carsharing services in Berlin. Wielinski et al. (2015) also made this comparison (FFCS versus stationbased) with a different methodology in Montreal, using a targeted survey, GPS tracking for FFCS cars and four databases of transactional data for both services (Communauto). Becker et al. (2017) later compared user groups of station-based and FFCS systems in Basel (Switzerland).

FFCS operational problems (parking prices, walking distance to FFCS cars, car relocation strategies) comprise the second step towards a better knowledge of FFCS systems. The impacts and implications of different parking prices on FFCS demand were analysed in Zurich by Ciari, Balac, and Balmer (2015). From the operational point of view, there are two ways to increase FFCS service frequency: by increasing the number of cars (which is quite costly) or by implementing relocation strategies in FFCS car mobility. The miles driven by FFCS staff to redistribute the vehicles among the most demanded city zones, usually at the end of the day, must be considered in any sustainability and operational cost-benefit analysis, which is why relocation strategies are important. Although the literature on relocation strategies for traditional station-based carsharing is fairly extensive (Nair \& Miller-Hooks, 2011), FFCS systems provide more options for interacting with users by offering them incentives to relocate the car themselves. Especially if economically motivated, users can deliver the car to an alternative destination to the final one, and walk (or take public transport) a greater distance to their final destination. In the city of Hamburg,
Herrmann et al. (2014) used survey campaigns to study different pricing incentives for users in the case of smart relocation strategies. Future smart relocation strategies were favourably accepted by users, and tolerance to walking and waiting for an available car was revealed as an important variable influencing FFCS demand. This survey was replicated later among university students in Madrid (Ampudia-Renuncio et al., 2018; Guirao, Ampudia-Renuncio, Molina, \& García-Valdecasas, 2018), showing the importance of the walking tolerance towards an available FFCS car.

Until now, the literature review clearly reveals a gap in the analysis of real FFCS flows due mainly to the difficulties in obtaining data directly from the FFCS companies. Only a few studies have benefited from real data from companies. Schmöller et al. (2015) used data from DriveNow or car2go in Munich and Berlin (two years of booking data and number of registered members for a shorter period of time) in order to describe carsharing usage and spatially identify the socioeconomic factors that influence demand for this type of carsharing. A few years later Müller et al. (2017) used booking data provided by DriveNow for the city of Berlin to design a negative binomial model to analyse the influence of land use and census data on FFCS demand (number of carsharing trip starts per district). This model was then validated in the cities of Munich and Cologne (with similar population sizes) obtaining satisfactory results. The main findings focused on determinants such as the area's centrality and parking availability, which lead to a higher number of bookings, together with the city areas where citizens are more open to new sustainable ICT technologies. From the methodological point of view, Müller et al. (2017) highlighted an important issue concerning alternative scientific tools to obtain real flow data by accessing and reading the FFCS operator's API (application programming interface). This interface is commonly used by FFCS members with their smartphone websites and provides real-time information on the distribution of available cars in the nearby area. Available cars have an identification code and show information about the status of the electric battery or fuel tank, which can be used to reconstruct trips and even make a distinction between bookings and rentals (real trips). Muiller et al. (2017) stressed the idea that the process of reconstructing trips from booking data is not easy (or automatic), as might be assumed a priori, and booking data should be treated with caution. Scientific hypotheses are necessary to design mechanisms to identify real FFCS flows and avoid errors. One example of these difficulties is the interpretation of the (non-) availability of a vehicle on the map: this could be either due to a service trip (for operational reasons such as recharging or relocation strategies) or a customer trip. The different services offered by companies also makes this approach more difficult, which is why the interpretation of the booking data (harvested with the operators' API) in a city with many FFCS companies is more complicated.

We have found only a few examples of FFCS research using data harvested from the operators' API. The works by Habibi et al. (2017) and Ciociola et al. (2017) are good examples of this research line. Habibi et al. (2017) compared FFCS usage patterns and trends in 22 cities (both in Europe and the US) with data publicly available on the web pages of three different operators. Usage patterns consisted of trip length, utilisation rates and the time of day the FFCS trip occurs. The base dataset included vehicle availability harvested between 2014 and 2016 (with a sampling time of $60 \mathrm{~s}$ ), and allowed the identification of 27 million vehicle movements. Vehicle availability enabled other complementary variables to be collected for each trip: the geographical position of vehicles at the start and end time of the trip, the vehicle identification ID (number-plate code or operational code) and vehicle energy level (diesel/electric/petrol). The main findings concerned the FFCS usage pattern, which shows a smaller morning peak and a larger afternoon peak (with some exceptions such as New York and Madrid), and this profile followed most other modes of transport. Madrid and Hamburg had higher utilisation rates, while Madrid differs from the other cities in showing an additional peak around lunch time. Although 


\section{ANÁLISIS DEL IMPACTO DE LOS SISTEMAS DE FREE-FLOATING CARSHARING EN ENTORNOS URBANOS UTILIZANDO DATOS WEB: APLICACIÓN A LA CIUDAD DE MADRID}

the authors did not include an origin-destination trip analysis (with the exception of one example for Stockholm), they found that the most popular origins and destinations were further than $500 \mathrm{~m}$ from a metro (or regional train) station. According to Habibi et al, (2017), this indicates that FFCS is probably being used as a complementary mode of transport to - rather than as a substitution for - public transport.

Ciociola et al. (2017) designed a web platform to harvest and analyse FFCS data from two operators (car2go and Enjoy) during 52 days in the city of Turin (Italy). The platform collected data in real time (each minute), stored the data in a data lake and built historical series before augmenting and processing them. Although the harvested data allowed a good temporal and spatial analysis, they acknowledged that "ingenuity" must be used to clean the results and address issues such as collection problems (website failures, identification of cars undergoing maintenance or recharging), GPS fix limitations (which may erroneously let a car "move") or platform design features (e.g., asynchronous or synchronous). To ensure the web platform is a good observatory for understanding the future development of carsharing and public transport systems, Ciociola et al. (2017) proposed this as primary tool that should be combined with user surveys (as a more traditional methodology). One of the main methodological contributions of this research, apart from the spatial analysis, is the comparison of FFCS and equivalent travel times using public transport. The main findings show that FFCS trips in Turin are $36 \%$ shorter (on average) than on public transport, and preference for FCCS begins when public transport time is over $10 \mathrm{~min}$. This analysis would be impossible using only surveys, and highlights the importance of estimating real-time trips when official data is unavailable.

This paper analyses the temporal and spatial distribution of FFCS trips in Madrid by designing a web-based platform to track FFCS cars and create a reliable dataset. This is a pioneering experience in Madrid, a city with a long tradition of public transport and one of the highest FFCS utilisation rates in the world. The next section describes the evolution of FFCS carsharing in Madrid in order to understand the specific features of the case study used to apply the methodology.

\section{Madrid case study}

One of the main concerns in urban areas around the world is air pollution (WHO, 2014), and despite the positive trends in air quality in Spain (Querol et al., 2014), Madrid still exceeds legal air quality limits according to Directive 2008/50/EC (Madrid City Council, 2016). In 2016 , for example, in nine of the city's 24 air quality monitoring stations, the recorded annual means were above the $\mathrm{NO}_{2}$ annual legal limits $\left(40 \mu \mathrm{g} \cdot \mathrm{m}^{-3}\right)$. The city council has therefore designed pollution protocols to be implemented during high-pollution episodes (Borge et al., 2018), promoted low emissions parking policies (Madrid City Council, 2005; Madrid City Council, 2012) and defined a restricted low emission area (Madrid City Council, 2018).

Electric carsharing systems have mushroomed in Madrid since 2015 , in response to the favourable parking policies promoted by Madrid city council under the pressure of air pollution threats. There are currently several companies operating FFCS fleets in Madrid, in addition to a public station-based bike-sharing system with 2500 units, and other companies that have implemented free-floating motorbike sharing systems (four companies with approximately 2000 electric motorbikes at the time of the data acquisition). Recently, given the proliferation of several companies that operate electric scooters, the city council has established a maximum limit of 10,000 units throughout the city.

The first to see the city's potential was car2go, a German company with a long experience in the sector. Although it began to implement this kind of systems in 2008, it did not arrive in Madrid until November 2015. Today the Daimler subsidiary operates in 25 cities worldwide, using different Mercedes-Benz and Smart models. It started in Madrid with 500 units of Smart's two-seater model, but has recently incorporated some four-seater Smart vehicles and offers the lowest rate in the city: $0.21 € / \mathrm{min}$. Due to the compactness of both Smart models, they are ideal for moving and parking in congested cities with limited on-street parking. It should be noted that there are only three cities (Madrid, Amsterdam and Stuttgart) where car2go's fleets are entirely battery electric vehicles (BEVs). Unlike other places, the vehicles are charged only by the service operators, instead of offering users the possibility of charging in exchange for rate reductions.

The second company in the city was Emov, a start-up with no previous experience elsewhere. It was set up in December 2016 as a joint venture between the French car manufacturer PSA Group and the Spanish parking management company Eysa, although all the shares have recently been acquired by the former. The vehicle used is the compact four-seater BEV Citroen C-Zero, of which Emov currently has a fleet of over 600 units. The rate at the time of data collection was $0.24 € / \mathrm{min}$, although it has lately been increased to $0.27 € / \mathrm{min}$.

After the data acquisition for this research had begun, another two operators of this kind of shared car fleets emerged. In December 2017, Zity was launched by the Spanish infrastructure developer Ferrovial Group in collaboration with the French car maker Renault. This start-up manages a fleet of 650 Renault Zoe BEVs and has the largest service area in the city, which allows its users to reach the airport and some nearby municipalities. In addition to the $0.26 € / \mathrm{min}$ rate, users can maintain the car rental at a cheaper rate while it is parked $(0.09 € /$ min). Another system called Wible, part-owned by the South Korean automobile manufacturer Kia and the Spanish energy company Repsol, was launched in June 2018. It is the first system to use plug-in hybrid electric vehicles (PHEV) instead of BEVs: it has 500 Kia Niro model cars and charges a rate of $0.28 € / \mathrm{min}$. The appearance of new operators complicates the analysis of the web data. The operation is modified by including new service areas or reserved parking spaces in its service area, or by offering new features for users such as maintaining the car reservation at a reduced rate while it is parked, which makes the study of the FFCS O-D flows more complex. The introduction of hybrid fleets prevents any analysis of the environmental benefits with the acquired web data, since there is no information available on VKTs (vehiclekilometres travelled) driven in "clean mode".

These four FFCS systems operators currently coexist in the Spanish capital city, with a total fleet of over 2000 cars and an average service area of $80 \mathrm{~km}^{2}$. Fig. 1 shows the service areas of the first two operators at the time of the data acquisition. Most of this area is what is known as the "Central Almond", surrounded by the M-30 ring-road and containing the most central districts. Paseo de la Castellana and its continuation, Paseo de Recoletos and Paseo del Prado, is the longest and most important road axis, and crosses the city from north to south. The main business centres are located along its northern and central part, and it borders the downtown district in the southern zone. Another point of interest in the city is the main university campus, located on the northwest limit of the Central Almond.

Recently, in November 2018, a new concept known as low emission areas (LEA) was created within the Spanish capital's traffic regulation (Madrid City Council, 2018). The first to be implemented was the Madrid Central LEA, corresponding to the central district of the capital where most of its tourist attractions and historical areas are located. This regulation allows electric vehicles, among others, to access, circulate and park in this area, and restricts access, circulation and parking by internal combustion engine (ICE) vehicles to specific circumstances only. Low emission areas are understood as a set of duly delimited roads in which special measures are implemented to regulate access, circulation and parking in order to reduce pollution from traffic. Madrid Central was created with the aim of reducing pollution levels, promoting more sustainable mobility, easing traffic flow and recovering public space for pedestrians. Previous experiences of LEA zones in London and Munich have demonstrated the efficiency of this type of measures (Ellison, Greaves, \& Hensher, 2013; Fensterer et al., 2014). Although it has yet to provide results, the research developed by Anas 


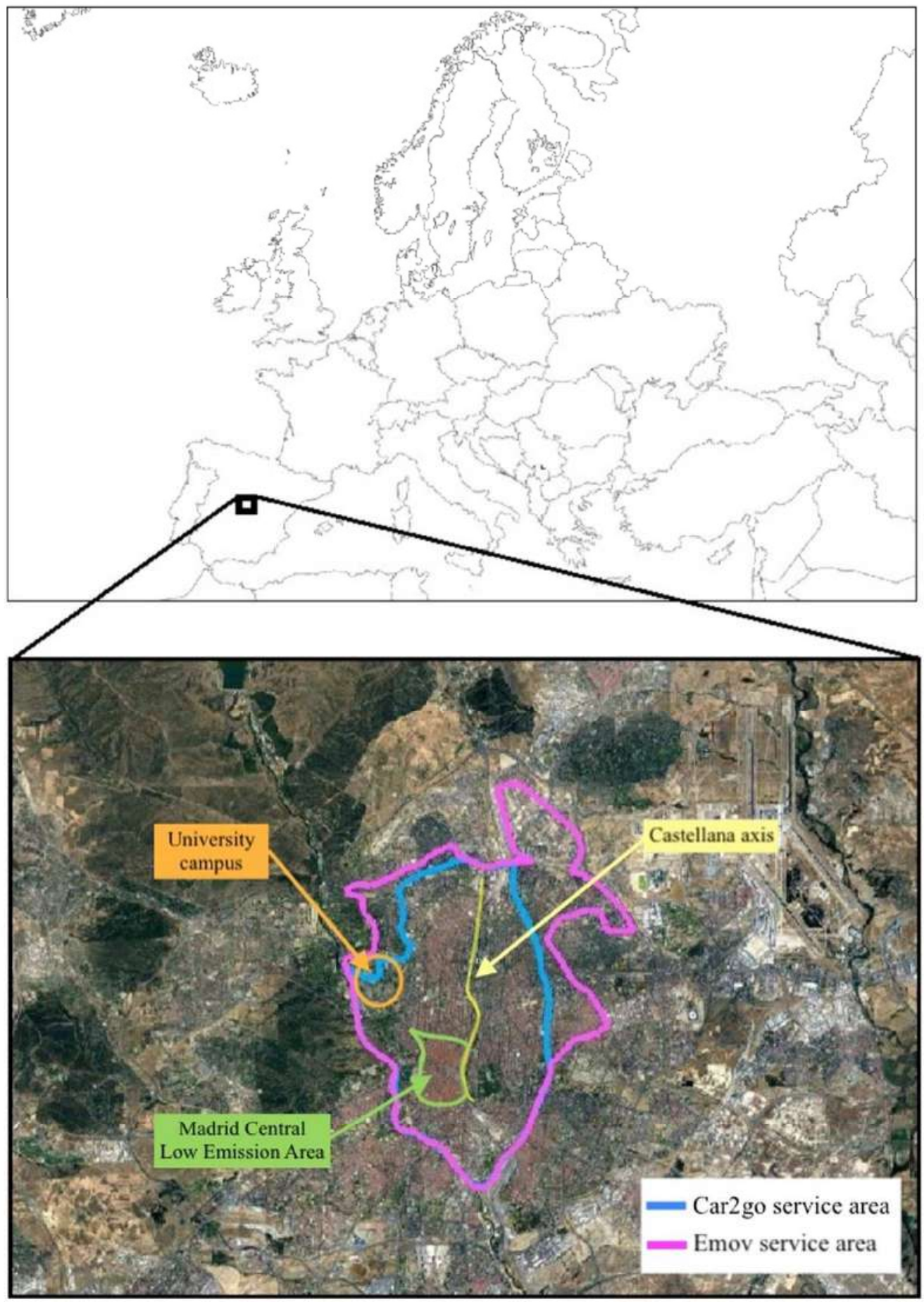

Fig. 1. Location of Car2go and Emov service areas in Madrid. 


\section{ANÁLISIS DEL IMPACTO DE LOS SISTEMAS DE FREE-FLOATING CARSHARING EN ENTORNOS URBANOS UTILIZANDO DATOS WEB: APLICACIÓN A LA CIUDAD DE MADRID}

Ahmed (2019) has demonstrated that Madrid Central has been successful in terms of reducing the intensity of vehicle traffic (and emissions) and the time spent by vehicles on roads. Although it is too early to describe the benefits of this regulation in detail, it is evident that it will favour the circulation and parking of FFCS vehicles in the city centre.

This research aims to design a methodology to estimate the temporal and spatial distribution of FFCS trips in a city. Madrid has been selected as case study due to its representativeness with, as one of cities with the highest utilisation rates for FFCS vehicles. Madrid will be, therefore, the case study of this research, taking as reference the first two operators that deployed their system in the city. Web data were harvested during the period between November 28, 2017 and April 12, 2018, when Car2go had been operating for two years in Madrid and Emov just one, implying that the "novelty effect" of FFCS systems had passed. A third operator (Zity) had just started in December 2017. This period of analysis seeks to establish a diagnosis of the first years of usage of these systems, when they already have a large number of established customers (more than $70 \%$ of FFCS demand). Later operators have slightly modified the standard operation (for example, all-day reservation is allowed, and a parked car can be reserved at a lower price per minute to ensure it is available for a return trip). This is a pioneering research for Madrid, as little work has been done to study the impacts of these new FFCS systems in the city. A previous study by Ampudia-Renuncio et al. (2018) analysed the limitations of FFCS car availability in the city's main university campus, and university students' acceptance of FFCS (tolerance to waiting and walking towards an available car). The methodology was quite simple and limited to the car2go operator, based on surveys and systematic observations of the operator's website. The evolution of availability was registered by systematic observation and by counting the vehicles offered on the operator's website. This information was constantly refreshed in real time so the presence of cars in a study area could be tracked. These observations were programmed sequentially every $30 \mathrm{~min}$ from 3 October 2016 to 9 October 2016 (Sunday), giving 48 screenshots in one day and 337 observations during the week. Although this paper provided the first FFCS results in Spain, it was limited to a specific area of the city and to a unique population profile (students). The data collection comprised observations made every $30 \mathrm{~min}$, which was a long observation time, and the screenshots allowed only the study of availability but not the trip description (origin-destination, length and duration).

This paper goes one step further, using revealed web-based data to analyse the origin-destination flows throughout the city. As the first analysis of its type done in Spain, the conclusions are interesting to discover Spaniards' usage patterns and acceptance of these systems, and to estimate the impact generated on a high-quality and reliable public transport network.

\section{Data and methods}

\subsection{Data sources}

The data sources in our research are mainly concentrated on the web sites of the FFCS companies. Current carsharing systems, especially free-floating carsharing, rely on communication technologies to inform their users of the availability of the vehicles and their identification, position and energy or fuel status. This information is freely presented worldwide (all FFCS systems in the world works through apps) and its collection needs the design of a web based platform. Madrid is a representative case in the FFCS operation context, with one of the highest utilisation rates for FFCS vehicles and the existence of many operating companies. The data used in this research have been obtained from the public data available on the websites of two free-floating carsharing operators in Madrid: Car2go and Emov.

The design of the platform, which is part of the methodology, requires a process of definition of a FFCS trip profile and the original data need to be processed and filtered before the analysis. For example, no information about the car is transmitted when it is unavailable, and the record of its positions is only maintained in the operator's private database. In order to obtain a precise database, we need to know how a FFCS system works, and specifically, the peculiarities of the systems already operating in Madrid. While data collection could be seen as a systematised process, in this case, a previous study is needed and their subsequent interpretation and analysis requires a detailed knowledge of the vehicle reservation, rental and refuelling processes. As has been pointed out in the state of the art of this paper (Ciociola et al., 2017; Müller et al., 2017), erroneous conclusions would be achieved without this proper interpretation. It is a complex process in which, in addition to the tool and the platform, it is also necessary to perform the meticulous task - once the data have been recorded - of ensuring that only the representative records of a trip are stored and the database is cleaned in order to achieve a correct interpretation of the results.

\subsection{Design of a web-based tracking platform}

The design of a web-based platform in order to harvest FFCS cars data from public data sources is part of the methodology of this research. Similar platform design could be extrapolated to other case studies in the world. We have to take into account that no information about the car is transmitted when it is unavailable. That means that the FFCS car position, identification and its energy status, can therefore only be harvested and stored while a car is available. The platform, called CarTrack, was designed specifically for this purpose, in which two crawlers were built to collect data from the car2go and Emov websites. CarTrack can harvest in real time only the data freely made available on the FFCS operators' website.

The platform was structured to create a record each time a car disappears from the interface which ends when the car reappears, and usually corresponds to a trip. This record corresponds to a FFCS trip profile because, the moment the trip ends and the user closes the car, the car becomes available again, as long as it is above the minimum battery level. To book a car from the smartphone app, the user has only to select the car that interests him or her, based on either its proximity or the battery level he or she needs to make the trip. At this point the car disappears from the display interface and is no longer available to other users.

The data acquisition service gathers the latitude, longitude, battery level, address and car ID of all available cars (those that are free and can be rented) every $30 \mathrm{~s}$. As mentioned above, each vehicle segment of the FFCS (a record) provides metadata to a centralized Big-Data platform. This integrated information is made available to any user through an API (Application Programming Interface) or through its direct publication on a web platform (graphical or numerical output). In the case of this study, the information was obtained through "passive listening", i.e. collecting public metadata provided by the companies during each user's query to the platform during the vehicle renting process via app. The final cadence of the information capture was $30 \mathrm{~s}$. The reason was that, after analysing the number of positive identifications of available vehicles in relation to the rate of consultations to the booking and rental vehicle platform, it was observed that the positive identification of available vehicles increased upon reaching the sampling rate of $30 \mathrm{~s}$. Nonetheless, below this value the number of identified vehicles decreased, due to limitations related to the computational resources of the system developed for passive listening. The software developed for "passive listening" was sometimes exceeded, and the acquisition time was longer than the sampling rate.

Although data were acquired for a more extended period of time, a time period between November 28, 2017 and April 12, 2018 was selected for the analysis in this paper. These months correspond with a proper functioning, when the pilot stage of the platform was finished and the operational problems were finally overcome. Data collected was stored in a Cassandra database which offers high availability and 


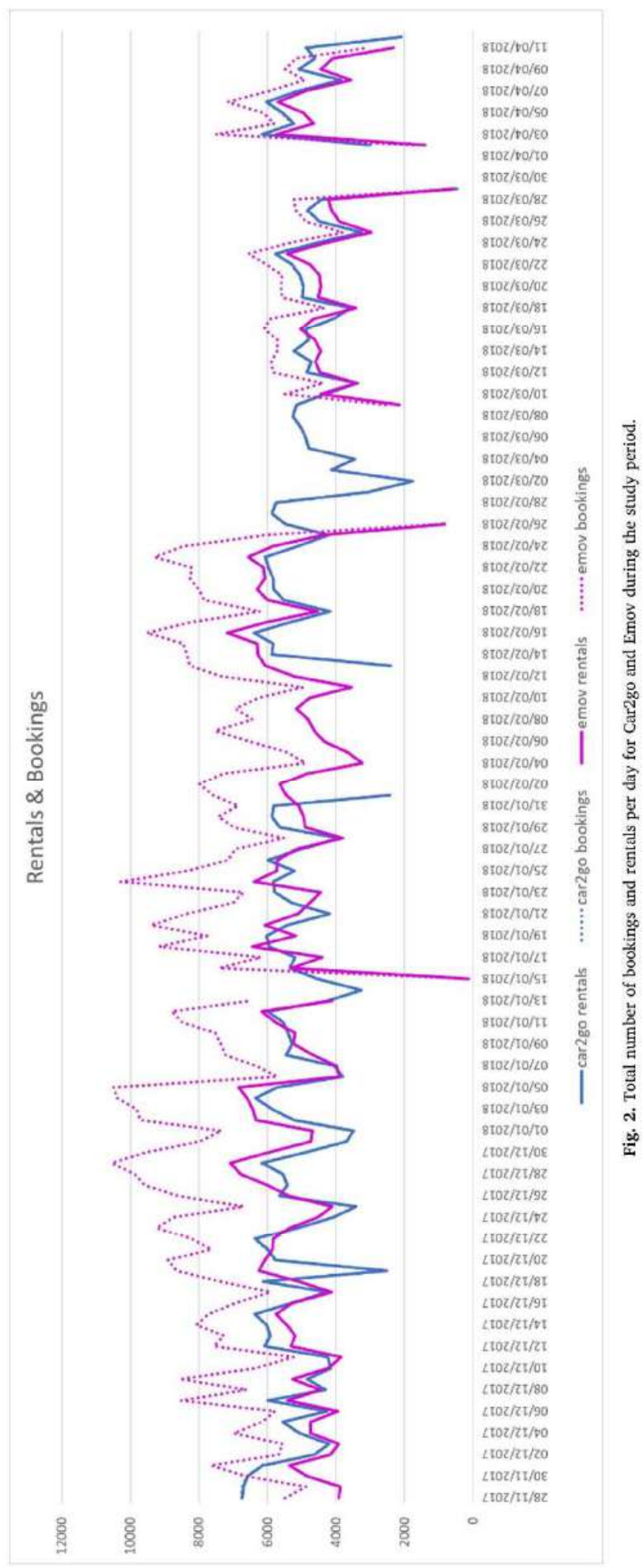




\section{ANÁLISIS DEL IMPACTO DE LOS SISTEMAS DE FREE-FLOATING CARSHARING EN ENTORNOS URBANOS UTILIZANDO DATOS WEB: APLICACIÓN A LA CIUDAD DE MADRID}

throughput. The initial and final location, trip distance, battery consumption and trip time was stored for each car. Trip location was stored not only by latitude and longitude but also by the initial and final neighbourhood. This latter data will allow designing an origin-destination trip analysis by city district or neighbourhood. The calculated trips can be queried by car ID, initial or final neighbourhood and starting date. The platform therefore provides information with which to obtain trip matrices and some insights into the behaviour of carsharing users.

Although the CarTrack platform provides services and functionality to gather and store data from different carsharing providers in the city of Madrid, the stage of analysis couldn't been implemented direct inside the platform due to the previous need of the dataset "cleaning". System connectivity anomalies were first identified in order to clean them from the database. The anomalies in the data record may be due either to operator's system falls that make all vehicles unavailable and, therefore, they do not appear on the website, or to acquisition platform falls when losing the route due to operator's website updates. During the period of time analysed, events occurred that meant that the day's $\log$ was not recorded, either partially or totally, as can be seen in Fig. 2 . These periods were completely removed from the database, by extracting records produced on days with an abnormally low number of records (evidently, those days have not been considered in the analyses).

\subsection{Criteria to identify FFCS trips}

A lack of information about a car's availability on its operator's website usually means that a trip is underway, but may be due to other reasons. Normally, the car is being driven by another user, but it may sometimes be unavailable because someone has booked without making the trip. Other times it may be undergoing charging, refuelling, maintenance or cleaning operations, or there may simply be system connectivity problems that cause the car to be temporarily out of service. Criteria to identify real trips (rentals) were based on the analysis of the bookings. Bookings without a trip were identified in order to divide the dataset into two clusters: bookings and rentals. The first group consists of all the records in which the car is unavailable, whether a trip takes place or not. The second group is created by excluding all trips with no movement (the origin and destination neighbourhoods are the same) and whose battery consumption is null. This group consists of trips that comply with the following conditions: they either start and end in different neighbourhoods, the battery level at the end of the trip is lower than the initial battery level, or both. Staff trips for charging or refuelling, maintenance and cleaning tasks or relocations were discarded. According to the data in the existing systems in Madrid, a car must be charged between once a day and once every two days and, considering the speed of charging and the fact that maintenance tasks can be done in the meantime, this is estimated to be $5 \%$ of the time.

\section{Analysis process, results and discussion}

As studied in the state of art, there are only a few examples in the literature in which web-based methodologies are used to harvest public FFCS data from the operating companies (Ciociola et al, 2017; Habibi et al., 2017). Criteria from identification of trips depend on the author and on the type of FFCS operation and even the final cadence of the information capture can differ depending of the design of the tracking platform. In our study, cadence was reduced to $30 \mathrm{~s}$ (while $60 \mathrm{~s}$ were used in previous studies), collecting a wider range of movements. Our analysis also allows checking some results obtained by Habibi for the city of Madrid.

While data collection is a systematised process, their subsequent interpretation and analysis requires a detailed knowledge of vehicle reservation, rental and refuelling processes. Erroneous conclusions would be achieved without this proper interpretation. After cleaning the database and obtaining the rental cluster, days with unique behaviours were detected, such as Christmas holidays, Easter holidays, other national, regional or local holidays, working days before holidays which follow the same pattern as Fridays even though they are not, etc. The remaining days were categorised by day of the week to obtain the average daily profile by type of day.

The data analysis was organised in topics, which are described in the following paragraphs. First, the time profile of the FFCS trips was analysed in order to characterise the patterns governing the use of these systems in the selected city. Second, user behaviour was assessed, specifically the distributions of bookings and trip duration. Third, the trip-generating and trip-attraction areas in the city were analysed to identify the most attractive trips for FFCS use. Fourth, the potential impact of these systems on public transport was analysed by comparing routes and travel times between both means of transport to determine whether there are public transport alternatives on the routes most demanded by the FFCS and to identify the role played by FFCS in the city's transportation system.

\subsection{Temporal distribution of FFCS trips}

Fig. 2 shows the distribution of bookings and rentals throughout the entire time period analysed (from November 28, 2017 to April 12, 2018). It can be seen that there are very few bookings without a trip (the dashed line practically coincides with the solid line) in Car2go cars, depicted in blue. However, the opposite is true of Emov, shown in pink, which has a high number of bookings in which a trip does not take place. This is because some Emov users make consecutive bookings: when the booking time has elapsed, they re-book the same car until they finally use it after several bookings or sometimes do not use it at all. As of February 2018, the company limited consecutive reservations since it generated a loss of income due to reduced availability. A disproportionate number of bookings are cancelled in the initial minutes, which may be not because a user is booking a car, but because cars are momentarily disconnected from the system and the acquisition platform perceives that a booking has been made.

Average daily time profiles were obtained using daily data by day type (Fig. 3). A similar behaviour is observed for both operators. Habibi et al. (2017) pointed out this peculiarity of the Spanish capital, since in other large cities they found only two peaks. It is observed that three trip peaks occur on working days (Monday to Friday). The first is in the morning rush hour when most trips to working areas take place (7:00-9:59 h). It is slightly displaced in time (until 10:00 h) compared to the private vehicle rush hour. This is due to congestion and its incompatibility with the benefit of using FFCS, since the greater the congestion, the more expensive the trip. The second trip peak is at lunchtime (13:00-15:59 h), where it should be noted that Spaniards usually have lunch later than in other European countries. Finally, the third peak is in the evening (18:00-20:59 h) when people return home and engage in leisure activities. On weekend days (Saturday and Sunday), only two peaks occur, at around $1 \mathrm{pm}$ and $8 \mathrm{pm}$. The hourly maximum is on Friday between 14:00 and 15:00 h, when around 400 trips begin on average.

A slightly higher number of reservations were observed for Car2go during the study period, even though it had a smaller fleet (Car2go: 500 cars; Emov: 600 cars). This may be due to the versatility of the twoseater model - the Smart Fortwo - used by the German operator compared to the model used by Emov - the Citroen Zero - which has four seats and is therefore somewhat larger and more difficult to park. On the other hand, Car2go's per-minute rates were cheaper than Emov's $(0.21 € / \mathrm{min}$ vs $0.24 \mathrm{\epsilon} / \mathrm{min})$ at the time of the data acquisition. This causes users to prefer the former for daily trips such as commuting in which they travel alone, while for leisure journeys in which trips are shared with friends and family they prefer to pay a higher price for the four-seater model, as can be seen in the trips generated on Friday afternoon and on Saturday and Sunday. 


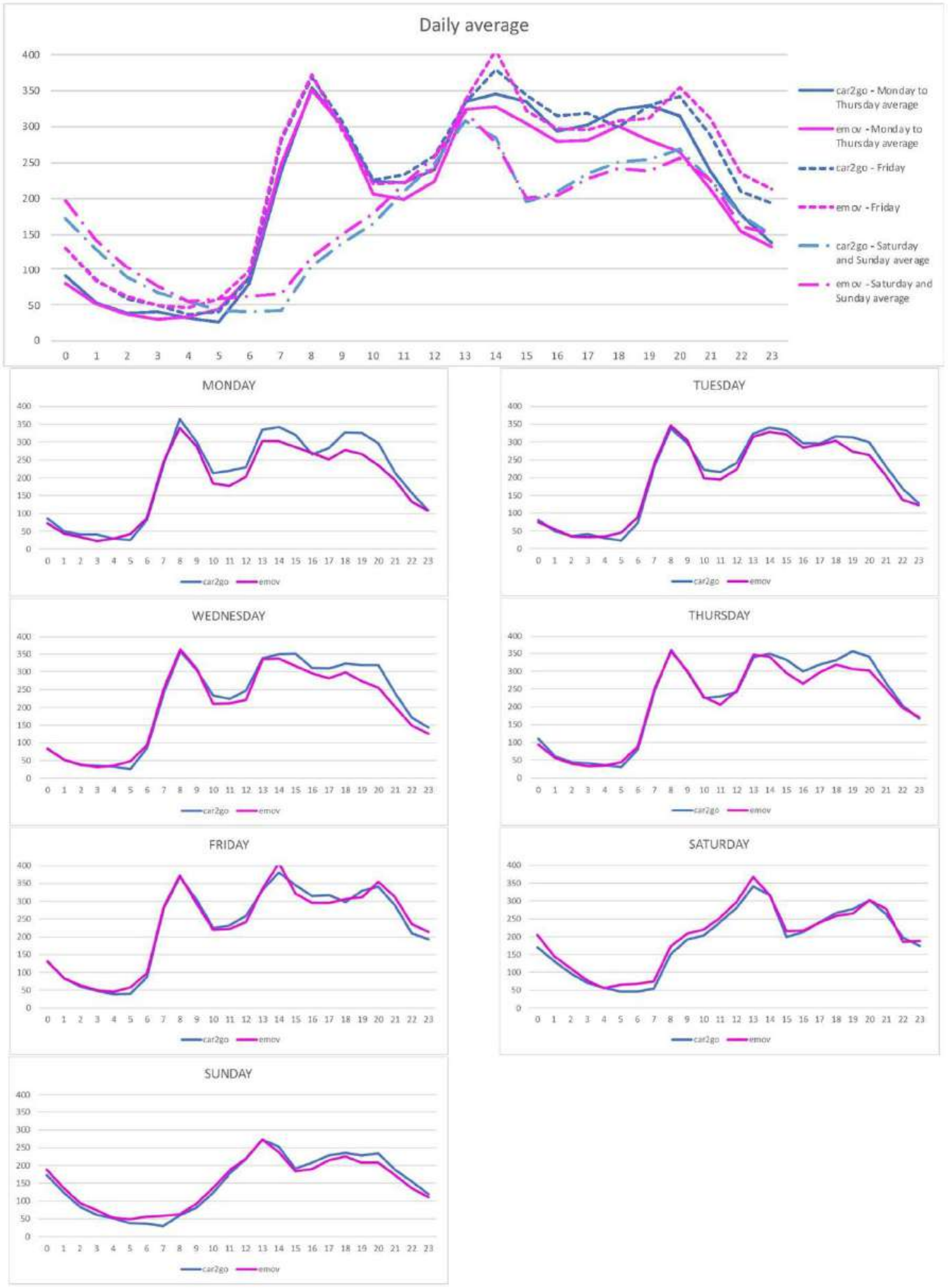

Fig. 3. Average number of rentals per day of the week and per Emov and Car2go operating company. 


\section{ANÁLISIS DEL IMPACTO DE LOS SISTEMAS DE FREE-FLOATING CARSHARING EN ENTORNOS URBANOS UTILIZANDO DATOS WEB: APLICACIÓN A LA CIUDAD DE MADRID}

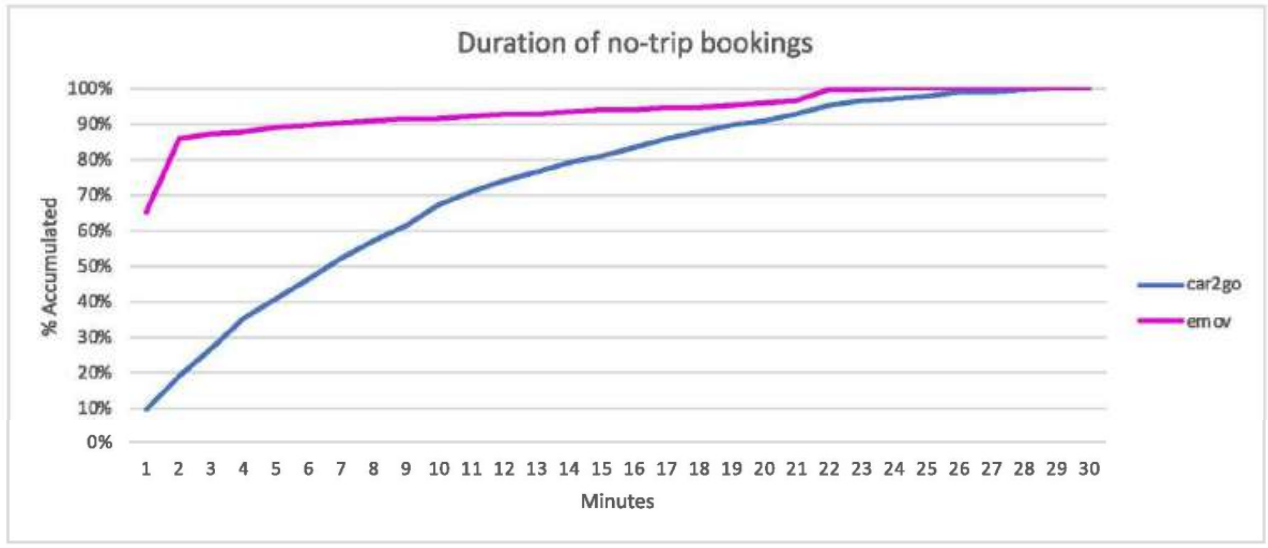

Fig. 4. Duration in minutes of no-trip bookings.

Similar patterns are observed between the two companies, as seen from the average number of rentals during weekdays or at weekends. A comparison of working days reveals that the use of systems in the lunchtime rush hour is slightly higher on Fridays, generally because people tend to leave work earlier on these days. Overall, Mondays can be said to be the weekday with least use. At the weekends, system usage is higher on Saturdays, when more trips occur in the early morning and the two peaks are more pronounced.

\subsection{User behaviour related to trip reservation and duration}

One important aspect to bear in mind when analysing the profitability of a FFCS system is how users tend to use it. Since the rates vary with the duration of the rental, a system will not only be profitable if many trips are made throughout the day, but also if these trips have sufficient duration. According to data from the local operators and the research of Habibi et al. (2017), a FFCS car in Madrid makes around ten trips per day, more than in other places where these systems have been established for longer (Kortum et al., 2016). This section analyses the duration of the rentals and the bookings that are subsequently cancelled, as an indicator of the loss of availability in the system.

Fig. 4 shows the duration of no-trip bookings in minutes and provides information on how long users reserve the car before cancelling a booking. It should be noted that for both operators the maximum booking time is $20 \mathrm{~min}$, after which the booking is automatically cancelled. However, as we said before, the user can cancel a booking and re-book the same car instantly, and our platform may not have detected the instant at which the car was available. Not all bookings finish before or exactly at $20 \mathrm{~min}$. In fact, they can last longer than $20 \mathrm{~min}$ due to the accumulation of several consecutive bookings. For this reason the graph in Fig. 4 does not show $100 \%$ at $20 \mathrm{~min}$.

In the case of Emov, $80 \%$ of no-trip bookings were cancelled in the first $2 \mathrm{~min}$. As already indicated, this may be due to connectivity failures and not because real bookings are being made. The cancellation rate rises constantly until it reaches $20 \mathrm{~min}$, when any trips that have not been started are automatically cancelled. However, this step occurs 1 min later, probably because of the delay caused by the sampling time. For car2go, the cancellation of no-trip bookings grows asymptotically until it reaches $95 \%$ at the maximum reservation time.

Another indicator to consider is the length of time users rent a car. Fig. 5 shows the distribution of car rentals; that is, the total records in which a trip is made. Although the mode of distribution is $22 \mathrm{~min}$, the median is around $27 \mathrm{~min}$. $20 \%$ of trips last less than $18 \mathrm{~min}$ and $20 \%$ last more than $47 \mathrm{~min}$. We must bear in mind that this time includes not only the trip but also the reservation time. According to the operators' information, the average reservation time is $8 \mathrm{~min}$, although the maximum time allowed is $20 \mathrm{~min}$.

The distribution of trip duration in both services is similar. Nevertheless, when observing the cumulative percentage, the proportion of Emov trips does not attain the levels of car2go trips, with over $15 \%$ of Emov trips lasting more than $120 \mathrm{~min}$, and barely $6 \%$ for car2go. This difference is due to Emov's daily rental rates, which offer a flat rate after $5 \mathrm{~h}$ of vehicle rental.

\subsection{Spatial distribution of trips}

Both operators' service areas contain more successful areas in terms of generation or travel attraction. A spatial analysis was done to identify these areas using the city's administrative districts as spatial units. The municipality of Madrid is made up of 21 districts which are in turn divided into an average of six neighbourhoods each. There are around 50 neighbourhoods within the service areas, most of which belong to the seven districts inside the Central Almond.

Fig. 6 shows how often each neighbourhood is an origin (left) or destination (right). Dark green means that a neighbourhood is often a trip generator, while dark red implies it is a trip attractor. A large proportion of trips have their origin, destination or both in the neighbourhoods along the axis of Paseo de la Castellana, the main artery intersecting the city from north to south. It is worth noting that very few trips are generated in the central district due to parking difficulties. The introduction of the Madrid Central low emission area a few months after the acquisition of data for this study may have increased the trips generated or attracted in the central district, as this local policy allows the circulation and parking of electric vehicles such as those of Car2go and Emov in the centre while restricting access by internal combustion engine vehicles.

We wanted to go one step further by analysing the flows in specific periods, especially at rush hours. Figs. 7 and 8 depict the most frequent origin-destination (20 top flows) that occur in the selected time periods (peak flow periods). Each flow is represented by a degraded line that goes from the centroid of the origin district, in green, to the centroid of the destination neighbourhood, in red. When the movement occurs in both directions, the line has a red-green-red gradient. Return trips, which have their origin and destination in the same neighbourhood, are shown with a red dot.

An analysis of the daily travel profile shows three timeslots of $3 \mathrm{~h}$ each working day, coinciding with the time at which more trips start: 7:00-10:00 h, 13:00-16:00 $\mathrm{h}$ and 18:00-21:00 h. The first corresponds to the morning rush hour, which in the case of FFCS systems extends until later. As previously mentioned, the second is a peculiarity that 


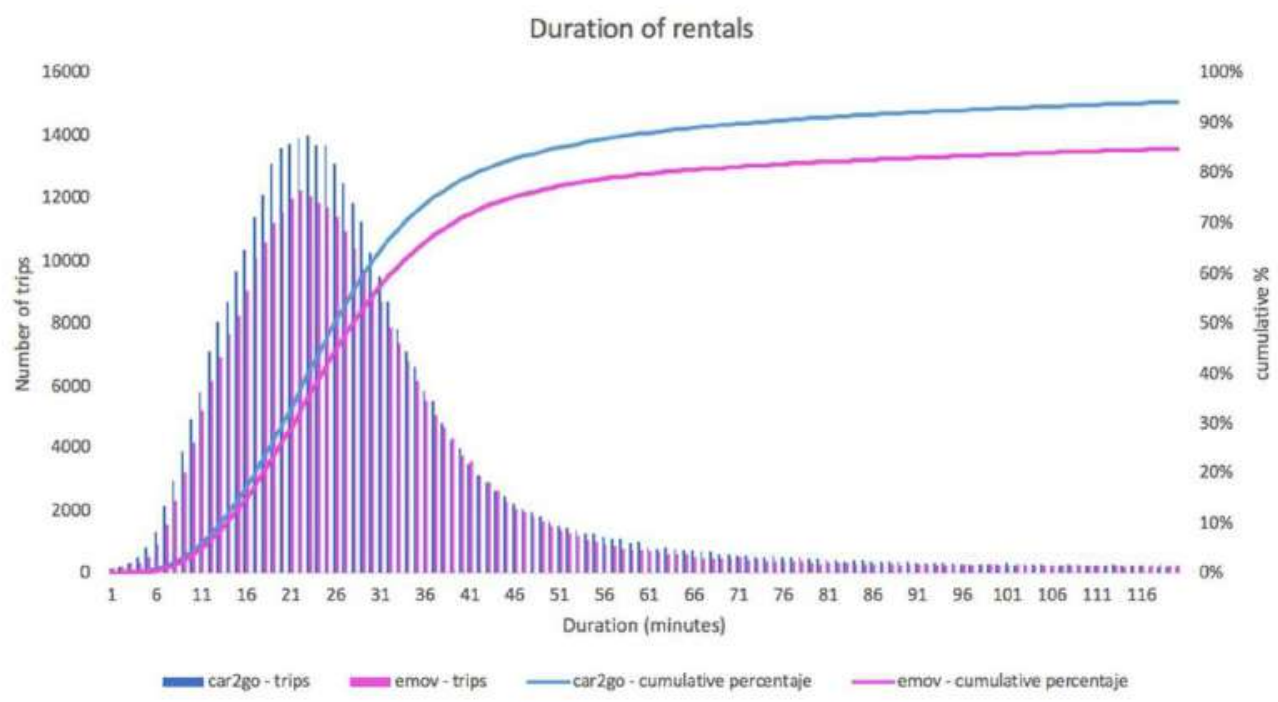

Fig. 5. Duration of rentals in minutes.

occurs in Madrid, since a high number of trips take place at lunchtime. The third period coincides with the return home from work and with the performance of leisure activities. Taking into account the types of movement that take place in the city, it was decided to group the flow representation of the first two periods, from Monday to Friday, and the third, from Monday to Thursday, and to assess the flows on Friday separately. In general, working hours in Madrid's work centres end at around 18:00 or 19:00 h from Monday to Thursday and around 14:00 or
15:00 h on Fridays. For this reason, trips from 18:00 to 21:00 h on Fridays are understood to be for leisure, as on weekend days.

In the morning rush hour from Monday to Friday (Fig. 7a), trips from residential neighbourhoods to business hubs occur along the Paseo de la Castellana. It is observed that the most frequent trips cover greater distances than in other timeslots analysed. Between 13:00 and 16:00 h from Monday to Friday (Fig. 7b), the direction of some morning trips is reversed, indicating that some users return home. Compared to the
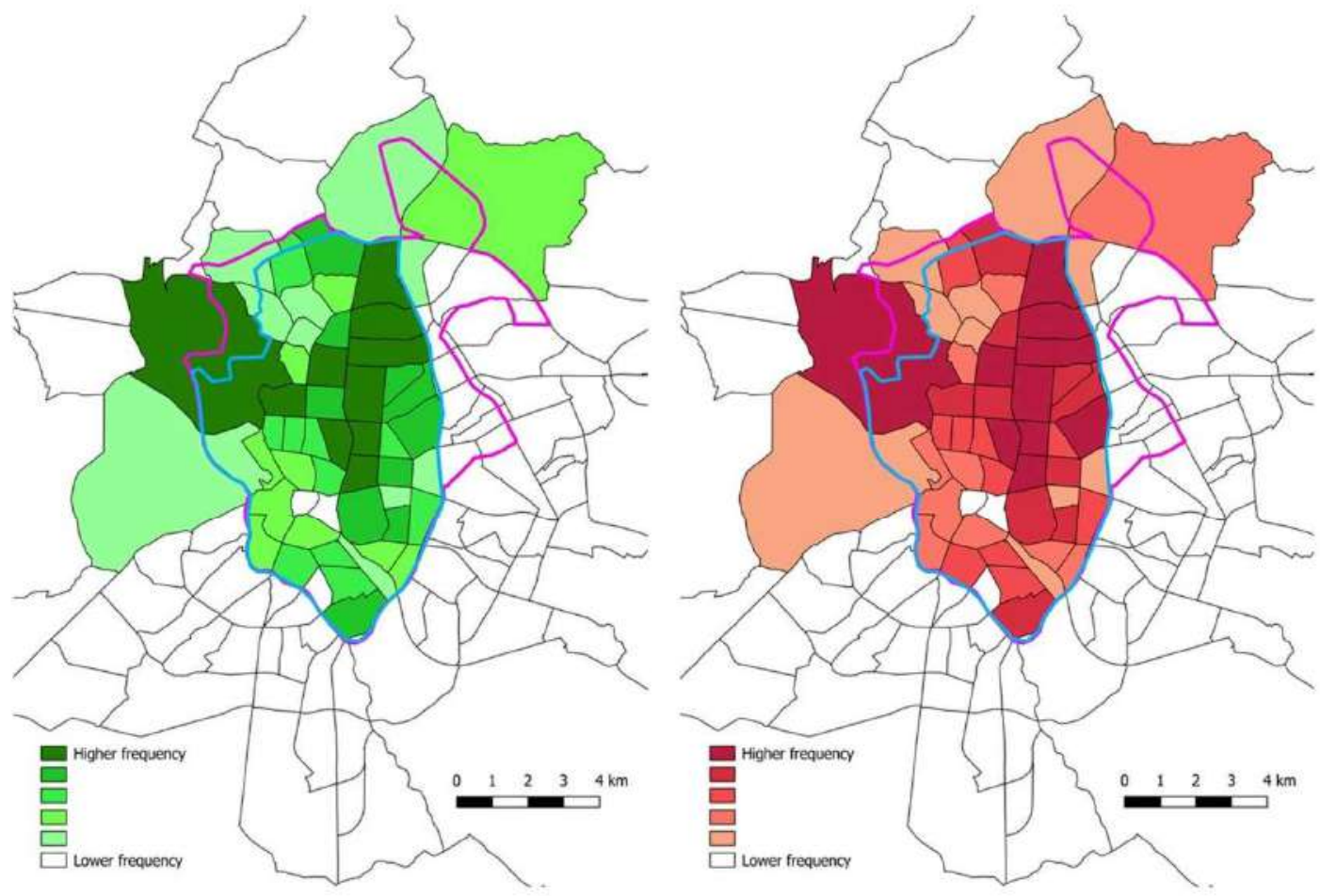

Fig. 6. Origins (left) and destinations (right) of all FFCS trips analysed. The divisions correspond to the city neighbourhoods. 


\section{ANÁLISIS DEL IMPACTO DE LOS SISTEMAS DE FREE-FLOATING CARSHARING EN ENTORNOS URBANOS UTILIZANDO DATOS WEB: APLICACIÓN A LA CIUDAD DE MADRID}
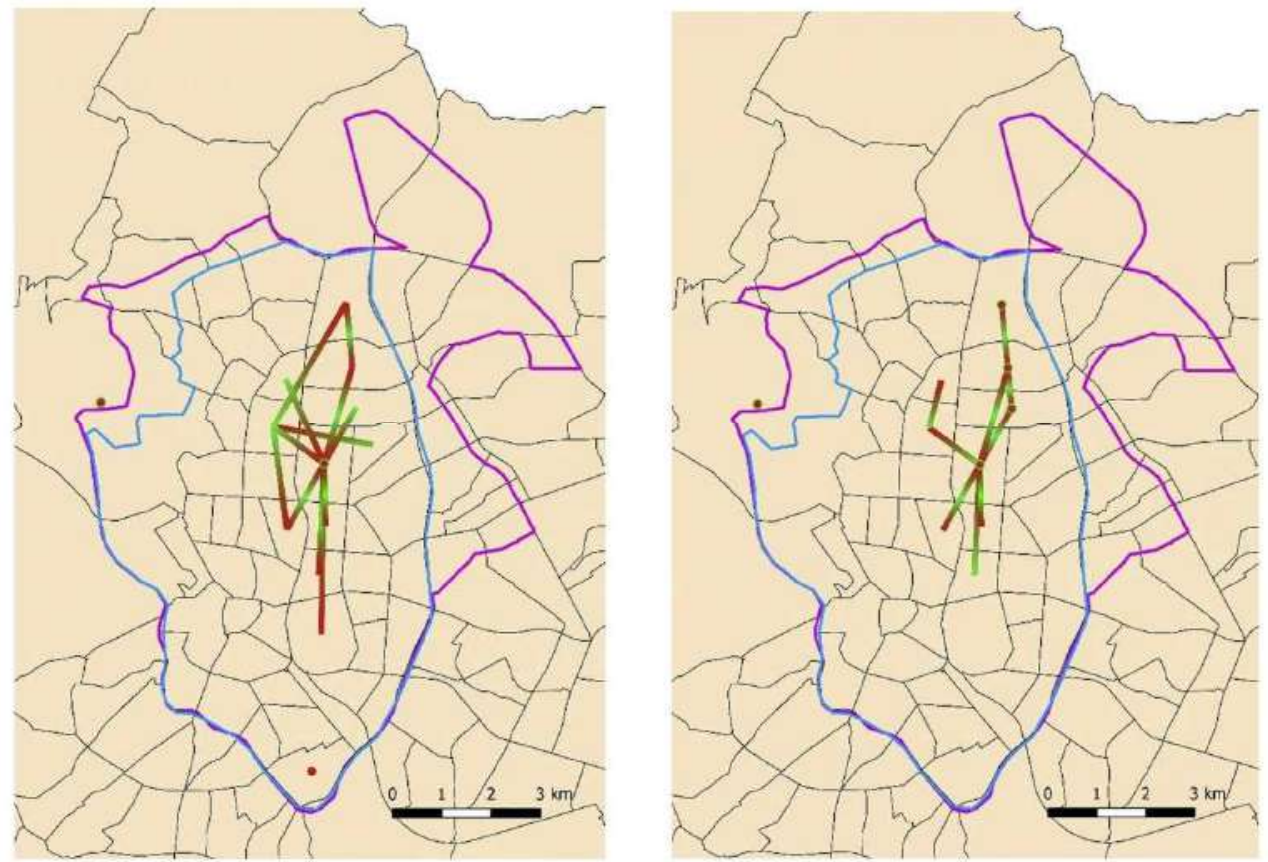

Fig. 7. Most frequent O-D flows Monday to Friday 7:00-10:00 h (left) and Monday to Friday 13:00-16:00 h (right).

morning period, round trips increase in the most commonly frequented neighbourhoods, as lunchtime is used to run errands. Nevertheless, in both timeslots the neighbourhood in which most trips are generated is also the neighbourhood where most trips finish: on average in the period studied, 32 trips per hour are generated from 7:00-10:00 $\mathrm{h}$ and 50 trips per hour are attracted, while an average of 45 trips are generated and 39 attracted between 13:00-16:00 h.

Fig. 8 shows the most frequent trips from 18:00-21:00 h. Trips to or from the University Campus-Ciudad Universitaria (around 20 trips per hour in each direction) located in the west, are highlighted on the map for Monday to Thursday (top left). On Friday evening (top right), and especially on Sunday evening (bottom right), return trips take place in remote neighbourhoods that are infrequent origins or destinations. Although the total number of trips in this period is similar to the other peak hours (except on Sunday), fewer trips are generated or attracted in the most frequent neighbourhoods (at most 25 trips per hour), expanding the range of trip routes produced.

\subsection{Impact on public transport}

Travel times and trip distances in free-floating carsharing vehicles were obtained with Google Maps according to their origin and destination location. Using these coordinates, the trip was also simulated in public transport (metro, urban bus or suburban trains) in accordance with Google Maps routes.

In the case of public transport, travel time includes walking time from the origin point to the station where the trip on public transport starts, and from the final station of the trip to the destination point, the average waiting time according to the lines in the optimal route, and travel time. The FFCS driving time is estimated by Google by obtaining the time from the initial rental position to the final rental position, without counting the reservation time prior to the start of the trip, which is included in the database records. Walking time from the trip origin to the car's initial position and from the car's final position to the trip destination must be considered. Previous studies showed that users are willing to walk a maximum distance of $300-500 \mathrm{~m}$ to reach an available car (Ampudia-Renuncio et al., 2018; Herrmann et al., 2014), so an extra $5 \mathrm{~min}$ has been added to all trips. Time from the car's final position to the trip destination has been omitted from the analysis, as it is considered that the car trip will end as close as possible to the destination.

Fig. 9 shows the comparison of average travel times on the optimal routes of the 60 most frequent O-D pairs (excluding round trips) during the morning peak time by car and public transportation. Trips that share the same origin and destination neighbourhood have been grouped to simplify their representation, calculating their average time. The graph shows that some trips from one neighbourhood to another can take almost $20 \mathrm{~min}$ longer by public transport, depending on the distance between them. Trips on public transport between close origindestination pairs have less extra time, although they proportionally represent a greater increase compared to the same trip by car. The time increase on public transport compared to the car is also shown in Fig. 10. It was found that short trips in FFCS can take up to $100 \%$ longer on public transport, reinforcing the idea that the most frequent trips are between nearby neighbourhoods, since the public transport alternative doubles the trip duration.

However, it has been found that the cost of trips in FFCS vehicles can be up to 3 times more expensive than in public transport (Fig. 11). In the sample analysed, it has been obtained that the cost to the user is, on average, almost double. The cost of a trip in an Emov vehicle is slightly higher than in a car2go one due to the per-minute rate $(0.21 €$ vs $0.24 €$ ). Meanwhile, in most trips in public transport, the costs are between 1.5 and $2 €$, taking into account that a single ticket is purchased. If the traveller has a transport pass or other discounted ticket modalities, the difference of costs is even bigger.

\subsection{Discussion of results}

Results obtained in this paper confirm that the web-based methods to analyse FFCS demand are the most effective way to study the FFCS 

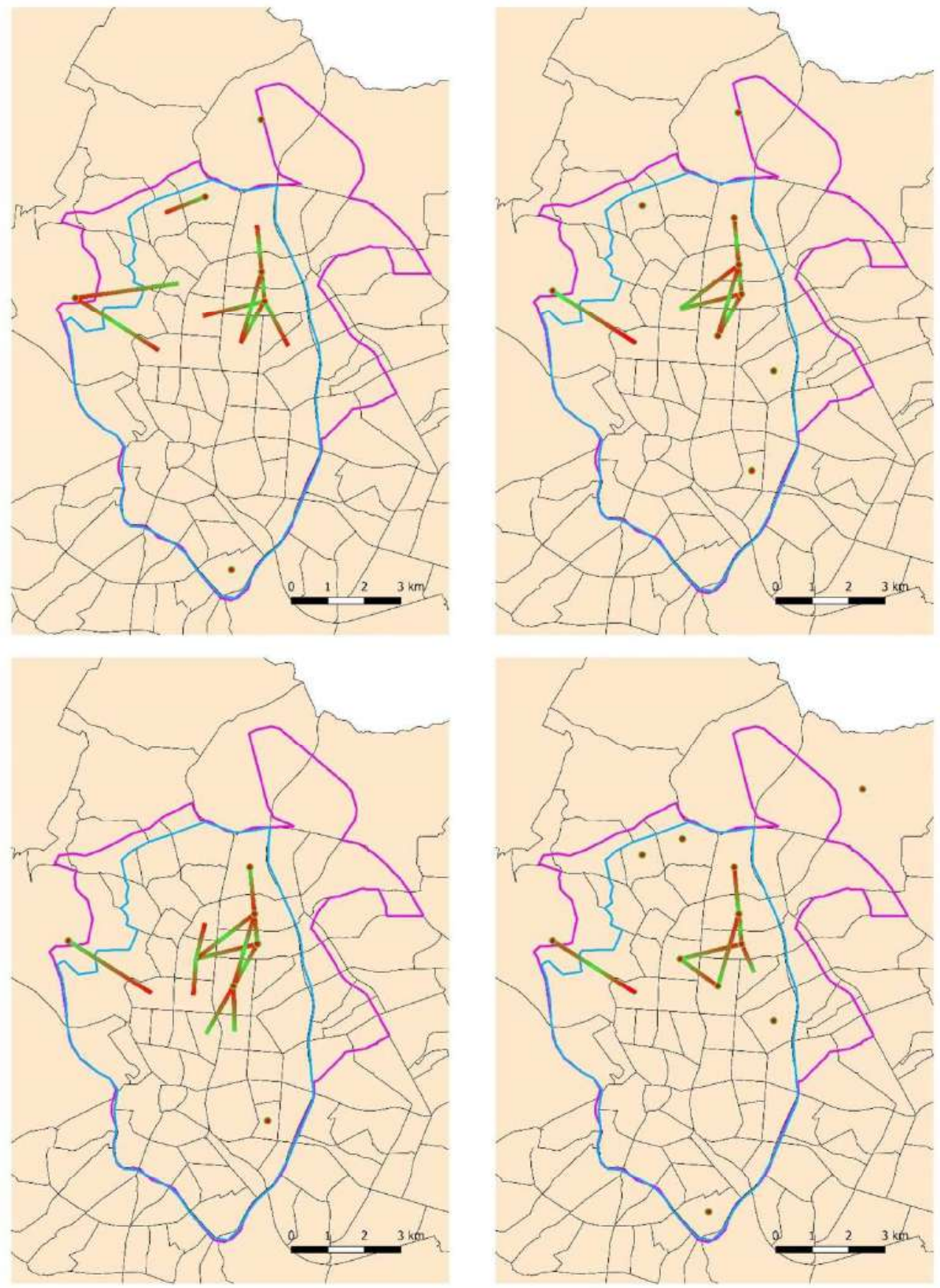

Fig. 8. Most frequent O-D flows from 18:00-21:00 h from Monday to Thursday (top left), on Friday (top right), Saturday (bottom left) and Sunday (bottom right).

user behaviour, as previous works developed by Habibi et al. (2017) and Ciociola et al. (2017) had already explored. The results obtained for Madrid are consistent, in terms of temporal distribution of trips, with the results obtained by Habibi et al. (2017) and also reflects a similar profile for the different FFCS companies that operates in the city. The analysis demonstrates that the stage of identification of trips cannot be a systematised process and needs a deep knowledge of the FFCS service in a city, in order to extrapolate the methodology to other international scenarios. The analysis on user behaviour related to trip reservation and duration could be understood if the FFCS service conditions were not clear in the research. Previous studies on FFCS, based on surveys (Ampudia-Renuncio et al., 2018; Herrmann et al., 2014), can 


\section{ANÁLISIS DEL IMPACTO DE LOS SISTEMAS DE FREE-FLOATING CARSHARING EN ENTORNOS URBANOS UTILIZANDO DATOS WEB: APLICACIÓN A LA CIUDAD DE MADRID}

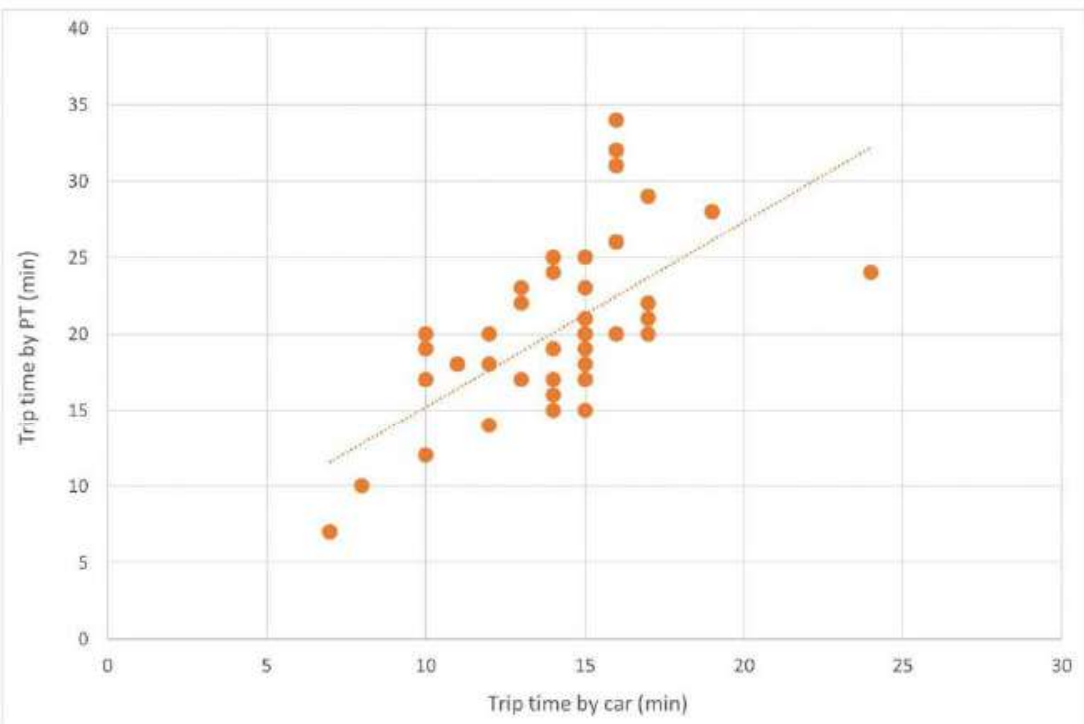

Fig. 9. Comparison of travel times by FFCS car and by public transport of most frequent O-D pairs during the morning peak time.

complement the web-based methods, as the maximum distance that a user is willing to walk towards an available FFCS car to rent, because this type of indicator is an important input to analyse data harvested from FFCS APIs through web-based platforms.

Finally, comparison between FFCS times and public transport times for FFCS users is closely dependent on the exact origin of the trip, which in the case of FFCS users is not usually the same as the place the FFCS car is parked. The FFCS user's coordinates are impossible to obtain while the reservation is being made, and are also subject to private data protection regulations. That is why this estimation is complex and the results should be treated with caution.
6. Conclusions

The aim of this paper was to obtain FFCS usage patterns by analysing the temporal and spatial distribution of trips through a city. There are only a few studies that use web-based methods to analyse FFCS flows with public available data from APIs, while the majority of FFCS previous studies have been based on survey and simulation methods. The contribution of this research has been the design of a platform (with a reduced cadence to collect and store FFCS data) and the definition of detailed criteria to identify FFCS trips. A dataset of about twenty weeks was extracted, including the trip data of the two most established operators in Madrid: Car2go and Emov. The analysis

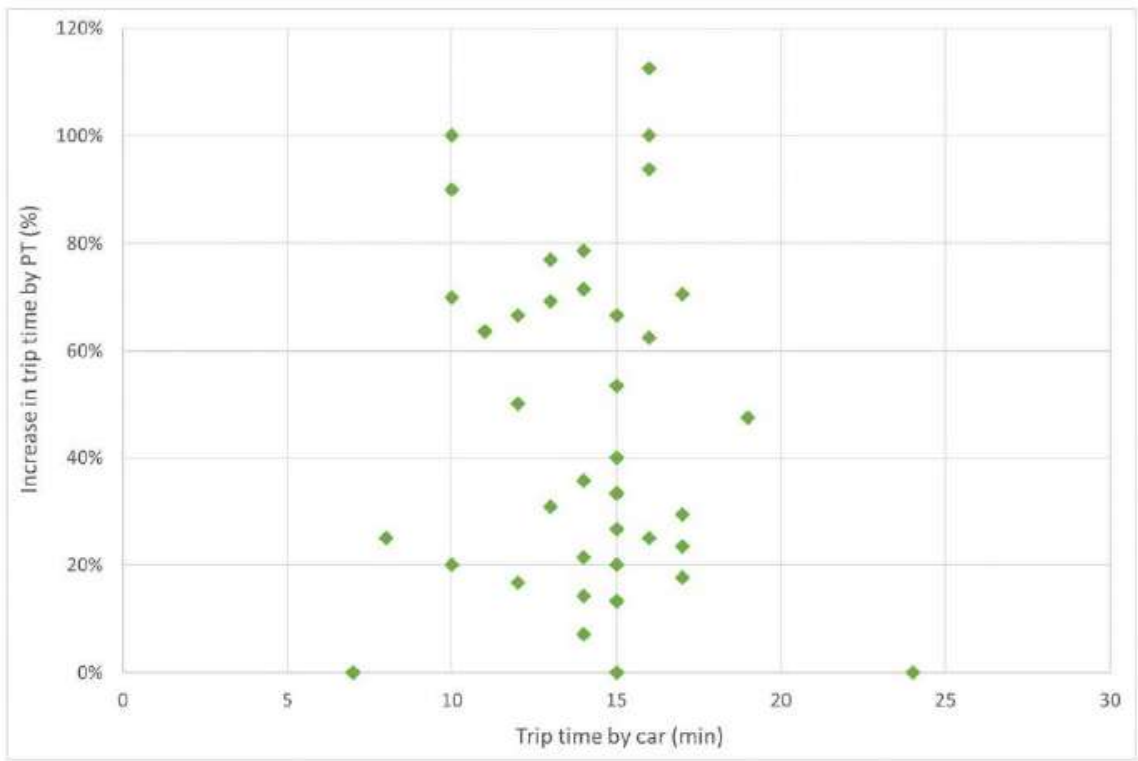

Fig. 10. Time increase on public transport compared to the trip duration by FCCS car of most frequent O-D pairs during the morning peak time. 
Cost increase in FFCS compared to public transport

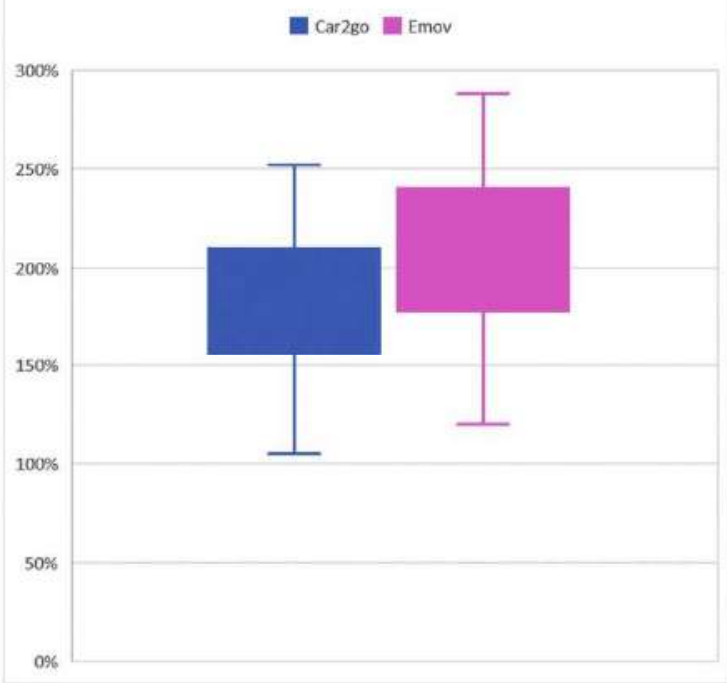

Fig. 11. Time increase on public transport compared to the trip duration by FCCS car of most frequent O-D pairs during the morning peak time.

of the temporal profile of FFCS trips shows that unlike other cities, Madrid has a lunchtime peak in addition to the usual morning and evening peaks. This was noted in the analysis of the beginnings of Car2go in Madrid (Habibi et al., 2017) and has now been confirmed with data from both Car2go and Emov now that the service is more mature.

User behaviour was assessed by extracting the distributions of notrip bookings and trip rental duration. In the case of no-trip bookings, it emerged that, except for possible connectivity failures, most cancellations are made in the first minutes and then gradually tail off. By representing the accumulated data, an asymptote can be seen in the maximum reservation time allowed by the operators. In terms of rental duration, it was found that the average reservation time is $27 \mathrm{~min}$, including the prior reservation and the trip. A larger proportion of Emov trips last longer, probably due to the possibility of all-day booking at a reduced rate. Regarding the spatial distribution of trips, it was shown that the neighbourhoods along the city's main axis road are frequent origins and destinations. These are areas with high connectivity and - more importantly - easy parking. Other areas such as the downtown district (like Madrid LEA) do not generate or attract as many trips as expected (probably due to parking limitations).

At the end of the study, travel times were compared with the optimal routes on the city's existing public transport modes. This revealed that FFCS systems sometimes act as a substitute for public transport, especially on trips between nearby areas in which travel time by public transport is doubled.

To the authors' best knowledge, this is the first study of free-floating carsharing flows in the city of Madrid as a whole, and the aim is to continue assessing the impacts of FFCS systems in the Spanish capital. Future research work will involve a closer look at the database and a more detailed analysis of trip generation and attraction in a spatialtemporal dimension. Comparison of routes and travel times is likely to be improved by incorporating the extraction of public transport data to the platform and using simulation to estimate the actual origin of the trip (taking the reservation time as the dataset). Future research should also investigate the effects of implementing low-emission areas (such as Madrid Central) on the spatial distribution of FFCS flows. At the time the data was collected, this LEA in Madrid was not a frequent origin and destination due to its limited parking availability, but this may have changed after the policy measures applied by the local authorities.

Finally, this study also reveals that the spatial distribution of FFCS flows in a city is closely dependent on its urban structure. The location of the main activities and parking availability are key issues to understand traffic flows, and explains why it is difficult to make a comparison of cities with FFCS systems, in terms of the spatial distribution of FFCS flows and the quality of the FFCS service. Parking regulations and the pricing of public transport vary widely between cities. Datasets on the number of street parking slots available per neighbourhood would constitute an important input to understand the spatial distribution of trips. This information is crucial to allow the policymakers to design policies to promote public transport in congested cities. In the end, parking regulations (as a policy for limiting private car access to city centres and decreasing pollution) also affect FFCS systems and must be taken into account in a holistic evaluation.

Pollution is a major issue in the big cities of the developed countries and, until now, planning policies have employed hard parking space restrictions as a way to prevent the private car from accessing the city centres. However, the territorial analysis of this paper has demonstrated that FFCS flows are concentrated between origin and destination areas of the city where parking space availability is high. Parking regulation is revealed as an important tool to attract FFCS cars and if FFCS are totally electric, this fact can represent an important way to reduce pollution. The design of parking regulation should promote not only private electric cars but also carsharing modes of electric cars. In the end, sharing trips using clean vehicles (plus a clean massive public transport) is the optimal way to reduce urban pollution derived from transport activities.

\section{Declaration of interests}

The authors declare that they have no known competing financial interests or personal relationships that could have appeared to influence the work reported in this paper.

\section{References}

Ampudia-Renuncio, M., Guirao, B., \& Molina-Sánchez, R. (2018). The impact of freefloating carsharing on sustainable cities: Analysis of first experiences in Madrid with the university campus. Sustainable Cities and Society, 43, 462-475.

Anas Ahmed, S. (2019). What has been the impact of Madrid Central on road usage and emissions since its implementation in November 2018? Retrieved from hitps://www. academia,edu/38808618/What has, been_the impact_of Madrid_Central on_road usage and emissions since its implementation in November 2018.

Bardhi, F., \& Eckhardt, G. M. (2012). Access-based consumption: The case of car sharing. Journal of consumer, 39(4), 881-898.

Becker, H., Ciari, F., \& Axhausen, K. W. (2017). Comparing car-sharing schemes in Switzerland: User groups and usage patterns. Transportation Research Part A, Pollicy and Practice, 97, 17-29.

Borge, R., Artiñano, B., Yague, C., Gomez-Moreno, F. J., Saiz.Lopez, A., Sastre, M., \& Barreiro, M. (2018). Application of a short-term air quality action plan in Madrid (Spain) under a high-pollution episode -Part I: Diagnostic and analysis from observations. Science of the Total Environment, 635, 1561-1573.

Ciari, F., Balac, M. \& Balmer, M. (2015). Modelling the effect of different pricing schemes on free-floating carsharing travel demand: $\mathrm{A}$ test case for Zurich, Switzerland. Transportation, 42(3), 413-433.

Ciari, F., Bock, B., \& Balmer, M. (2014). Modeling Station-based and free-floating carsharing demand: Test case study for Bertin. Transportation Research Record, 2416(1), $37-47$.

Ciociola, A., Cocca, M., Giordano, D., Mellia, M., Morichetta, A., Putina, A., \& Salutari, F. (2017). UMAP: Urban mobility analysis platform to harvest car sharing data. 2017 IFFE SmurtWorld, ubiquitotis intelligence \& computing advanced \& trusted computed, scalable computing \& communications, cloud \& big data computing, internet of people and smart city innovation (pp. 1-8).

Ellison, R. B., Greaves, S. P. \& Hensher, D. A. (2013). Five years of London's low emission zone: Effects on vehicle fleet composition and air quality. Trunsportution Research Part D: Transport and Environment, 23, 25-33,

Fensterer, V., Kïchenhoff, H. Maier, V., Wichmann, H., Breitner, S., Peters, A., ... Cyrys, J. (2014). Evaluation of the impact of low emission zone and heavy traffic ban in Munich (Germany) on the reduction of PM10 in ambient air. Intemational Journal of Environmental Research and Public Health, 11(5), 5094-5112.

Fimkorn, J. (2012). Triangulation of two methods measuring the impacts of a freefloating carsharing system in Germany. Transportation Research Part A: Pollicy and 


\section{ANÁLISIS DEL IMPACTO DE LOS SISTEMAS DE FREE-FLOATING CARSHARING EN ENTORNOS URBANOS UTILIZANDO DATOS WEB: APLICACIÓN A LA CIUDAD DE MADRID}

Proctice, 46(10), 1645-1672 2012

Muiller, $M$ (2011). What will be the environmental effects of new free. floating car-sharing systems? The case of car2go in Ulm. Ecological Economics, 7018), 1519-1528.

Firnkom, J, \& Muller, M. (2012), Selling mobility instead of cars: New business strategies of automakers and the impact on private vehicle holding. Business Strategy and the Environment, 21(4), 264-280.

Guirao, B., Ampudia-Renuncio, M., Molina, R., \& Garcia-Valdecasas, J. (2018). Student behaviour towards free-floating carsharing: First evidences of the experience in Madrid. Thansportarion Research Procedia, 33, 243-250,

Habibi, S., Sprei, F., Englundn, C., Pettersson, S, Voronov, A, Wedlin, J., \& Engdahl, H. (2017). Comparison of free-floating car sharing services in cities. European Council of Energy Efficient Economy Sumvner Study, 771-778.

Haefeli, U., Matti, D., Schreyer, C., \& Maibach, M. (2006). Evaluation car-shuring Bent: Federal Department of the Environment, Transport. Energy and Communications.

Heilig, M., Mallig, N., Schröder, O., Kagerbauer, M., \& Vortisch, P. (2017). implementation of free-floating and station-based carsharing in and agent-based travel demand model. Travel Behaviour and Soctety, 12, 151-158.

Herrmann, S., Schulte, F., \& Voß, S. (2014). Increasing acceptance of free-floating car sharing systems using smart relocation strategies: $\mathrm{A}$ survey based study of car2go Hamburg. International conference on computational logistics (pp. 151-162), Chami Springer (2014).

Katzev, R. (2003), Car sharing: A new approach to urban transportation problems. Analyses of Social Issues and Pubtic Policy, 3(1), 65-86.

Kopp, J., Gerike, R, \& Axhausen, K. W. (2015). Do sharing people behave differently? An empirical evaluation of the distinctive mobility patterns of free-floating car-sharing members, Transportation, 42(3), 449-469.

Kortum, K., Schönduwe, R., Stolte, B., \& Bock, B. (2016). Free-Floating Carsharing: CitySpecific Growth Rates and Success Factors. FactorsTransportation Research Procedia, 19, 328-340, hitps:/doi,org/10.1016/itirpro, 2016.12.092

Lamberton, C. P., \& Rose, R. L. (2012), When is ours better than mine? A framework for understanding and altering participation in commercial sharing systems. Journal of Marketing, 76(4), 109-125.

Le Vine, S., Adamot, O., \& Polak, J. W. (2014). Predicting new forms of activity/mobility patterns enabled by shared-mobility services through a needs-based stated response method: Case study of grocery shopping. Transpon Policy, 32, 60-68.

Loose, W. (2010). The state of European car-sharing (Project Momo Final Report D, 2).

Madrid City Council (2005). Ordenanza de Movilidad para la Ciadad de Madrid. Acuento Pleno de 26 de septiembre 2005. BOCM núm. 247 de 17 octubre 2005. Modificada por Acuerdo Pleno de 27 de jumio de 2012, BOCM nuim. 154 de 29 de funio de 2012.

Madrid City Council (2012). Ordenanza Fiscal Reguladora de la Tasa por Estadionamiento de Vetifalos en Determinadas Zonas de la Capital y de delimitación de la Zona de Estacionamiento Reguiado. Acuerdo Pleno de 9 de octubre 2001. Modificada por Acuerdo Pleno de 21 de diciembre de 2012. BOCM múm, (309 de 28 de diciembre de 2012).

Madrid City Council (2016). Madrid 2016 annual air quality assessment report (Calidad del aire Madrid 2016). General Directorate of Sustainability and Environmental Control, Madrid City Council. Available online -only Spanish version- at http://www. mambiente:munimadrid_es/opencms/export/sites/default/calaire/Anexos/ Memoria2016.pd!

Madrid City Council (2018). Sustainable mobility ordinance. Available online, only
Spanish version at Retrieved from https://sede.madrid.es/FrameWork/ generacionPDF/ANvizo18 45.pdf?idNormativa $=$ 5cedb732cef96610V gnVCM2000001f4a900aRCRD\&nombreFichero $=$ ANM2018 45 \&eachekey $=212$.

Martin, E., \& Shaheen, S. (2011). Greenhouse gas emission impacts of carsharing in North America. IEEE Transactions on Intelliguent Transportation Systems, 12(4), 1074-1086.

Martin, E., \& Shaheen, S. (2016). The impects of Car2go on vehicle ownership, modal shift. vehicle miltes traveied, and greenhouse gas cmissions: An analysis of fove North American cities. UC Berkeley: Transportation Sustainability Research Center3.

Miller, J. Correia, G. \& Bogenberger, K. (2017). An explanatory model approach for the spatial distribution of free-floating carsharing bookings $\mathrm{A}$ case-study of German ef. tes. Sustainability, $9(7), 1290$.

Nair, R., \& Miller-Hooks, E. (2011). Fleet management for vehicle sharing operations. Transportation Science, 45(4), 524-540,

Namiazu, M., \& Dowlatabadi, H. (2018), Vehicle ownership rectuction: A comparison of one-way and two-way carsharing systems. Transport Policy, 64, 38-50.

Niels, T., \& Bogenberger, K. (2017). Booking behavior of free-floating carsharing users empirical analysis of mobile phone app and booking data focusing on battery electric vehicles. Trunsportation Research Recond, 2650(1), 123-132.

Prettenthaler, F. E., \& Steininger, K. W. (1999). From ownership to service use llfestyle: The potential of car sharing. Ecological Economics, 28(3), 443-453.

Querol, X., Alastuey, A., Pandolfi, M., Reche, C., Pérez, N., Minguillón, M. C et al. Pallares, M. (2014), 2001-2012 trends on air quality in Spain. Science of the Total Environment, 490, 957-969.

Schmöller, S., Weikl, S., Milller, J., \& Bogenberger, K. (2015). Empirical analysis of free. floating carsharing usage: The Munich and Berlin case. Transportation Research Part C. Emerging Technologies, 56, 34-51.

Shaheen, S. A., \& Colien, A. P. (2007). Growth in worldwide carsharing: An international comparison. Transportation Research Recond, 1992(1), 81-89.

Shaheen, S. A., Cohen, A. P., \& Chung, M. S. (2009), North American carsharing: 10-Year retrospective. Thansportation Research Record, 2110(1), 35-44.

Sprei, F. (2018). Disrupting mobility. Energy Resenrch \& Social Science, 37, 238-242.

Sprei, F. Englund, C. Habibi, S. Pettersson, S., Voronov, A., Wedlin, J. \& Engdahl, H. (2017). Comparing electric vehicles and fossil driven vehicles in free-floating car sahring services. $5^{\text {th }}$ European buttery hybrid and fuel cell electrit vehicle congress, 14-16 March, 2017, Geneva, Switzerland.

Wang, Y, Yan, X., Zhou, Y., Xue, Q., \& Sun, L. (2017), Individuals' acceptance to free. Aloating electric carsharing mode: A web-based survey in China. International Journat of Environmental Research and Public Health, 14(5), 476.

Wielinski, G., Trépanier, M., \& Morency, C. (2015). What about free-floating carsharing? A look at the Montreal, Canada, case. Transportation Research Record, 2563(1), 28-36.

Wielinski, G. Trépanier. M. \& Morency, C (2017). Electric and hybrid car use in a freefloating carsharing system. International Journal of Suswainable Transportanion, I1(3), $161-169$.

Wilke, G. (2009). Explaining mobility through milieu membership. Analyses of the validity of milieu concepts using the example of ear-sharing. In C. Holz.Rau, \& J. Scheiner (Eds.). Subject-oriented approaches to iransport (pp. 24-39). (Dortmund).

World Health Organization (WHO) (2014). Ambient (outdoor) air quality and health. Fact sheet no 313. Updated March 2014 Available online at http://www. who.int mediacentre/factsheets/fs313/en. 


\title{
IV.4. ARTíCULO III: ELECTRIC FREE-FLOATING CARSHARING FOR SUSTAINABLE CITIES: CHARACTERIZATION OF FREQUENT TRIP PROFILES USING ACQUIRED RENTAL DATA.
}

\section{Article \\ Electric Free-Floating Carsharing for Sustainable Cities: Characterization of Frequent Trip Profiles Using Acquired Rental Data}

\author{
María Ampudia-Renuncio ${ }^{1}$, Begoña Guirao ${ }^{1, *} \odot$, Rafael Molina-Sanchez ${ }^{1} \odot$ and \\ Luis Bragança ${ }^{2} \odot$ \\ 1 Departamento de Ingeniería del Transporte, Territorio y Urbanismo, ETSI Caminos, Canales y Puertos, \\ Universidad Politécnica de Madrid, Profesor Aranguren s/n, 28040 Madrid, Spain; \\ m.ampudia@alumnos.upm.es (M.A.-R.); rafael.molina@upm.es (R.M.-S.) \\ 2 Centro do Território, Ambiente e Construçăo (C-TAC), Civil Engineering Department, University of Minho, \\ 4800 Guimarāes, Portugal; braganca@civil.uminho.pt \\ * Correspondence: begona.guirao@upm.es; Tel.: +34-91-0674218
}

Received: 13 January 2020; Accepted: 7 February 2020; Published: 9 February 2020

Abstract: Free-floating carsharing systems (FFCS) have become a new type of urban sustainable mobility, much more flexible than the previous station-based carsharing but limited by on-street parking availability and managed by municipal administrations. Literature on FFCS until now mostly relies on survey-based methodologies and simulations, and little research on FFCS has been devoted to the scientific analysis of real flows using revealed web-based data. This paper contributes to the existing literature with an analysis of FFCS trips using rental data collected directly from operators' websites, paying special attention to the most frequent trips. The added value of this research is that it provides the first analysis of the more FFCS demanding districts in the city of Madrid. The results showed that the main origin and destinations points were concentrated in low populated and high-income districts that also had good parking availability and connectivity to the public transportation network.

Keywords: free-floating carsharing; electric car; urban transportation; new mobility; climate change; urbanization

\section{Introduction}

When the first free-floating carsharing system (FFCS) was implemented in 2008 in the city of Ulm (Germany), carsharing had already been running for more than three decades, although it was a much more rigid form of mobility as it was based on stations [1]. Stations were a limitation for carsharing users, as they had to travel to the established points to pick-up or deliver a car. On the contrary, FFCS members are able to pick up and return a car straight from any point on the street, as long as they do it within a specified area of the city (usually called "the service area"). The concept of carsharing defined by Ciari et al [1] remains the same: "a fleet of cars can be shared by several users, who can drive a car when they need it, without having to own one", but new information and communication technologies (ICTs) have provided flexibility to the process of renting and using a FFCS car. These FFCS companies offer smartphone apps for the users to search and book a vehicle close to their current location in the city, inside the defined service area, in which they can rent and drop off cars near their final trip origin or destination. In terms of member cost, compared to taxi services or renting a car with a driver (ride-hailing services), prices for FFCS services are usually lower.

The flexibility of this new type of mobility has caused a rapid increase in demand for FFCS in recent years [2-4], but there are still many unanswered questions in relation to the impacts generated 
by FFCS on the urban transportation system: What are the main origins and destinations of these trips? Are FCCS systems used instead of alternative public transportation modes or active travel (e.g., cycling, walking)? How should local administrations deal with this new type of mobility? An FFCS has the opportunity to contribute to a low-carbon mobility transition in the case where the vehicles are electric and if the usage does not displace public transport use or active trips.

Some authors have pointed out that FFCS quality of service depends on the reliability of finding a car to rent near to the trip origin and the possibility of having a parking place near to the final destination [5,6]. These two variables depend on the number of vehicles provided by the FFCS companies in a city, the number of on-street parking slots available, and local regulation (some councils usually offer privileged access to street parking space for electric cars or less pollutant cars). Moreover, FFCS would not work in a city with parking restrictions and a poor quality or low-dense public transport system, because in the case a user had already rented a car, the web platform would not guarantee finding another car for the trip home or to his/her next activity. Local administrations could regulate on-street parking in a way to promote or deter FFCS systems, acting as "gatekeepers" of this new form of mobility [7]. But before implementing a new regulation context, a greater acknowledge and analysis of FFCS demand and flows is needed. This research approach has been conditioned by the scarcity of data provided directly by FFCS operators and, until now, most of the literature on FFCS relies on survey-based methodologies [8] and simulations $[4,9,10]$. Revealed web-based data, collected directly from operators' apps, are starting to be used as an alternative to reproduce origin-destination flows when FFCS data are not provided by operators (or as an external way to check data or figures provided by operators). These web-based methods work with the current position of available FFCS cars (at least when parked and not booked) and focus on various hypotheses to reconstruct the profile and the spatial distribution of trips. Reconstructing trips from booking data by using big data platforms is not an automatic task as stressed by Müller et al. [11], and more research is needed in this area, where there are only a few previous studies in the literature [12-14].

This paper contributes to the existing literature with a detailed analysis of FFCS web-based data obtained for Madrid, paying special attention to the socioeconomic variables of the most demanding districts, the main destinations of the flows, and the parking availability. This is a pioneering experience in Madrid, a city with one of the highest FFCS utilization rates in the world [15] and a long tradition of public transport, although the implementation of FFCS systems only took place recently in 2015. Madrid is also the only city in Europe, along with Amsterdam, where all FFCS car fleets are electric, while other study cases on Vienna, Berlin, Munich or Stockholm have a mix of electric and fossil fuel-powered vehicles.

This research not only focused on defining spatial and temporal distribution of trips but also on explaining them with regard to parking availability. In order to describe the research as a whole, this paper is organized as follows. Section 1 presents an introduction with the context and the objective of the study. Section 2 provides a brief literature review on the evolution of FFCS research. Section 3 provides the explanation of data sources and methodology used. Results of the study are presented in Section 4. Finally, Section 5 presents the main research conclusions.

\section{Literature Review}

Germany has been the cradle of FFCS and German companies, like Car2go and DriveNow/ReachNow, were, until now, the leaders of the market in FFCS around the world; Car2go provides services in 25 cities and DriveNow/ReachNow in 15. Recently, other major car manufacturers have also designed their own competing FFCS solutions, such as the South Korean Hyundai Motor Company and the French PSA Group. The FFCS operating companies are closely linked to the car manufacturing industry, because the concept of FFCS as "a product service" (i.e., mobility as a service) is being implemented in our cities, and this industry also wants to be an actor in this new scenario. New members of an FFCS company can be initiated in the experience of driving an electric vehicle (which is 
also a primary target for car manufacturing firms), producing, in addition, positive environmental impacts in cities.

In Germany, from a scientific point of view, it was clear from the beginning that directly transferring the results of the extensive literature on station-based systems to the urban FFCS was not possible [9]. All the direct effects of station-based carsharing were positive (reduction of total $\mathrm{CO}_{2}$ emissions and even reduction of vehicle-kilometers travelled individually), but the FFCS price structure and flexibility were so different that its effects probably would not be the same [16-21]. In this context, one of the first questions studied on FFCS was how they would affect existing station-based car-sharing systems [1,3,22]. Using simulation techniques, along with surveys, most of studies revealed an apparent complementarity of FFCS and station-based systems, and the new lines of research have rapidly re-focused on the evaluation of FFCS impacts and their principal operational problems which mainly include the possibility of finding a car and parking it near the final destination.

There have been some attempts to link the implementation of FFCS with a new attitude towards car ownership after trying FFCS services, especially an environmentally positive impact based on the willingness to forego a private car purchase in the future [8], but these results were based on survey data and more reliable research was needed. Real data on flows and users, provided by FFCS companies, seemed a priori the best resource to work with.

But in fact, the literature shows that the number of studies using real data provided directly by companies were very small and mainly focused on German cities. In Munich and Berlin, Schmöller et al. [23] used two years of booking data and the number of registered members for a shorter period of time (provided by DriveNow and Car2go). Their objective was to describe carsharing usage and to obtain a spatial distribution of flows, identifying the socio-economic factors that influence FFCS demand. Using booking data provided by DriveNow also in the city of Berlin, Müller et al. [11] studied, a few years later, the influence of land use and census data on FFCS demand through a negative binomial model. Areas' centrality, districts with citizens having a frequent use of ICTs, and parking availability were revealed as the main determinants which lead to higher demand (higher number of bookings). More recently, in Montreal (Canada), Wielinski et al. [24] have used Communauto data sets to empirically investigate members' behavior over time in a FFCS system. These data sets included not only FFCS bookings but also the members ID, so members were labeled according to their usage intensity for various periods of analysis.

Except for a few exceptional studies, already presented and usually financed by FFCS companies, it is very difficult for research teams to obtain real data sets. For that reason and as a way to check the data information provided by operating companies, a new body of research on various forms of passive data streams is being developed. Passive data is obtained by accessing and reading the FFCS operator's API (application programming interface). The FFCS' members commonly use this interface through their smartphone apps and are instantly informed with real-time information of available cars distribution in their nearby zone. Each available car has an identification code and shows the status of the electric battery or fuel tank. With this code, FFCS trips can be reconstructed (origin and destination) and we can even make a distinction between bookings and rentals (real trips). Two ideas should be taken into account before reconstructing trips. On the one hand, origin and destination of the available car are not exactly the origin and destination of the user trip since there are walkable distances to access FFCS cars that we ignore. On the other hand, the itinerary of a FFCS trip is not known (although FFCS travel time can be calculated) and, in most studies, it is estimated as a geodistance, namely, the straight-line distance between origin and destination. Müller et al. [11], after working with FFCS flows data provided by companies, raised an important issue concerning the complexity of using these methodologies to obtain real flow data by reading an operator's API. Booking data should be analyzed with caution, and this analysis cannot be automatized in order to avoid errors. Scientific hypotheses are necessary to, for example, interpret the (non-)availability of a vehicle on the map, either due to the fact of customer trip or to a service trip which are those made for service reasons such as battery/fuel recharging or relocation strategies. Moreover, the interpretation of the booking data 
is more complicated when different services are offered by companies in a city (different recharging options, different prices per renting minute, options to rent the FFCS vehicle when is already parked by paying an extra-price, etc.). Public on-street parking conditions and prices also differ from one city to another and this feature is also a determinant variable to study FFCS flows, once they have been estimated through passive data streams.

Despite these difficulties, the comparison of the FFCS trip profile among cities has been the main target among the first published studies using data harvested from the operators' API. Habibi et al. [15] and more recently Sprei et al. [25] are very good examples of this research line. By using data publicly available on the web pages of three different operators, Habibi et al. [15] compared FFCS trip profiles in 22 cities (both in Europe and the US) between 2014 and 2016. The identification of 27 million vehicle movements revealed a daily usage pattern with a smaller morning peak and a larger afternoon peak, with some exceptions such as New York and Madrid. Madrid and Hamburg had the highest utilization rates, and Madrid differed from other cities by showing an additional peak around lunchtime. The authors did not include an origin-destination trip analysis (except for one example for Stockholm) or a comparison of the on-street parking conditions among cities, probably due to the diversity of situations and different urban structures. Sprei et al. [25] followed Habibi et al.'s example and collected vehicle availability data between 2014 and 2017 from two different operators in 12 different cities located in Europe and the US. They focused on the study of FFCS travel time and usage patterns, devoting special efforts to analyzing mode displacements (rental times were compared to driving, walking or cycling times). Although their conclusions are quite interesting (for example, FFCS were mainly used for shorter trips with a median rental time of $27 \mathrm{~min}$ and actual driving time of around $15 \mathrm{~min}$, FFCS times were generally shorter than walking time but longer than cycling), a disaggregated analysis per city is needed, taking into account the spatial distribution of trips.

Ciociola et al. [12] developed a spatial FFCS analysis by concentrating their research on the city of Turin, Italy. With the design of a web platform to harvest and analyze FFCS data from two operators (i.e., Car2go and Enjoy), 52 days of operation were observed in real time. Data were stored in a data lake and historical series were built before augmenting and processing them. Although the spatial analysis obtained was very consistent with the urban structure, the authors acknowledged the necessity of conducting user surveys for a better interpretation of results. They also recognized that the data collection and cleaning processes need a complex task of results interpretation, identifying cars undergoing maintenance or recharging, website failures, GPS fix limitations, etc. Ampudia-Renuncio et al. [14] explored the temporal FFCS distribution of trips in Madrid by using operators' web data, obtaining results that validate the pattern obtained by Habibi et al. [15] for this city. The study of Cocciola et al. [12] also demonstrates the necessity of analyzing spatial FFCS flows in detail after being obtained through passive data streams. As those data depends on the urban structure, the public transport systems, and the availability and conditions of on-street parking, this analysis should be accomplished city by city, also taking into account the progressive implementation of the FFCS companies over time and their different service conditions per company. Ampudia-Renuncio et al. [14] analyzed spatial distribution of trips in Madrid, and the authors concluded that more research was needed in order to explain the variables that may condition the most frequent origins and destinations.

This paper delves into the analysis of spatial distribution of FFCS trips in Madrid through a web-based platform that tracks FFCS bookings and rentals. This research provides an in-depth examination of Madrid as a case study, a city with a long public transport tradition, and, like other European cities, experiencing a huge rise in free-floating carsharing systems, only implemented since 2015. The next section describes the Madrid case study, as well as information data sources and the methodology used to analyze the collected data.

\section{Materials and Methods}

The data sources in our research were mainly the websites of Madrid FFCS operating companies. With one of the highest utilization rates for FFCS vehicles and many operating companies, Madrid is a 
representative case of FFCS operation worldwide. In this research, the data were collected from public information available on the websites of two free-floating carsharing operators in Madrid, Car2go and Emov, which were the first ones to be implemented in the city. Web data were collected during the period between 28 November, 2017 and 12 April, 2018, when Car2go had already been operating in the city for two years and Emov for one, so the "novelty effect" of FFCS systems had already passed. The methodology included the design of a platform to capture data and a process of identification of real FFCS trips. For instance, the platform was able to determine when a car was unavailable, because no information about it was being broadcast. In order to obtain a precise database, we needed to know how a free-floating carsharing system worked and, specifically, the peculiarities of the systems that were already operating in Madrid.

\subsection{Madrid Case Study}

The Madrid City Council has been promoting low emissions parking policies since 2005 [26,27] under the pressure of air pollution threats. The regulated parking area was limited to the "Central Almond", the zone within the M-30 ring road which contains most of the central districts. Inside the Central Almond, Paseo de la Castellana and its continuation, Paseo de Recoletos, and Paseo del Prado, is the most important and longest road axis, crossing the city from north to south. This urban axis borders the downtown district in the southern zone, and the main business city areas are located along its northern and central part. Figure 1 depicts the distribution of the neighborhoods located within the FFCS services' areas which served as a spatial unit for the analysis performed in this research. The city of Madrid is divided into 21 districts that, in turn, are divided into neighborhoods (each neighborhood is identified by three digits, the first two digits being the code of the district). All districts from 1-7 and some neighborhoods belonging to other districts $(8,9,15$, and 16$)$ are located within the service areas of the operators.

Ten years after low-emission parking policies were implemented, electric FFCS arrived in the city: the first one was Car2go in 2015. In 2018, a low emission area (LEA) was created in the downtown district [28], a legislation that was unsuccessfully attempted to be repealed in 2019 when the government of the council was changed after municipal elections. This regulation fosters the access, circulation, and parking in this LEA of electric vehicles, among others, and does not allow such privileges to internal combustion engine (ICE) vehicles except in specific circumstances. It aims to cut down on pollution levels in the city but also to reduce congestion, promote more sustainable mobility, and recover public space for pedestrians in the area where most of the tourist attractions are located. However, due to the fact of its recent development, the impact of this regulation on FFCS has hardly been evaluated; however, everything seems to indicate that it is a policy which is supporting the operation of Madrid's FFCS systems, formed by fully electric fleets [29].

Starting from the beginning, the first FFCS company to be implemented in Madrid was Car2go which started operating in November 2015 with 500 units of Smart's two-seater model and offers the lowest rate in the city (currently from $€ 0.19 / \mathrm{min}$ ). Car2go initially operated in a confined area, but it expanded, and at the time of data acquisition, its service area corresponded to the Central Almond. Today, electric carsharing has mushroomed in Madrid in different forms: there are several companies operating FFCS fleets, in addition to a public station-based bike-sharing system with 2500 bikes and other companies operating with free-floating motorbike sharing: four companies with more than 2000 electric motorbikes at the time of this research. The second FFCS company to be implemented was Emov, set-up in December 2016 by Eysa and the French car manufacturer PSA Group, with no previous experience elsewhere. The vehicle used was the compact four-seater BEV Citroen C-Zero. Emov currently has a fleet of over 600 units and, at the time of data collection for this research, the rate was $€ 0.24 / \mathrm{min}$ (although it has lately been increased to $€ 0.27 / \mathrm{min}$ ).

Once the data acquisition for this research had begun, another two operators of FFCS emerged: Zity, in December 2017, and Wibble, in June 2018. This fact complicated the analysis of the web data, due to the different operation conditions offered by the new companies (new service areas, 
reserved parking spaces in its service area or offering new features for users such as maintaining the car reservation at a reduced rate while it is parked, etc.). Zity, owned by Ferrovial Group in collaboration with the French carmaker Renault, started with a fleet of 650 Renault Zoe BEVs and expanded the service area to the airport and some nearby municipalities. The rate was $€ 0.26 / \mathrm{min}$ rate but, in addition, members are given the opportunity to maintain the rental at a cheaper rate while the car is parked $(€ 0.09 / \mathrm{min})$. Wibble, owned by the South Korean automobile manufacturer Kia and the Spanish Repsol, was the first FFCS company to operate in Madrid with plug-in hybrid electric vehicles (PHEVs) instead of BEVs: $500 \mathrm{Kia}$ Niro model with a rate of $€ 0.28 / \mathrm{min}$.

The evolution of the kind of service offered by FFCS systems implemented in Madrid does not allow an aggregated worldwide comparative analysis. This paper aimed to analyze the first stage of FFCS implementation in Madrid, when the service operation of the two first companies (i.e., Car2go and Emov) was almost homogeneous. The data sources in our research were based on the websites of these two FFCS companies, and for this purpose, a platform to harvest car renting data was designed.

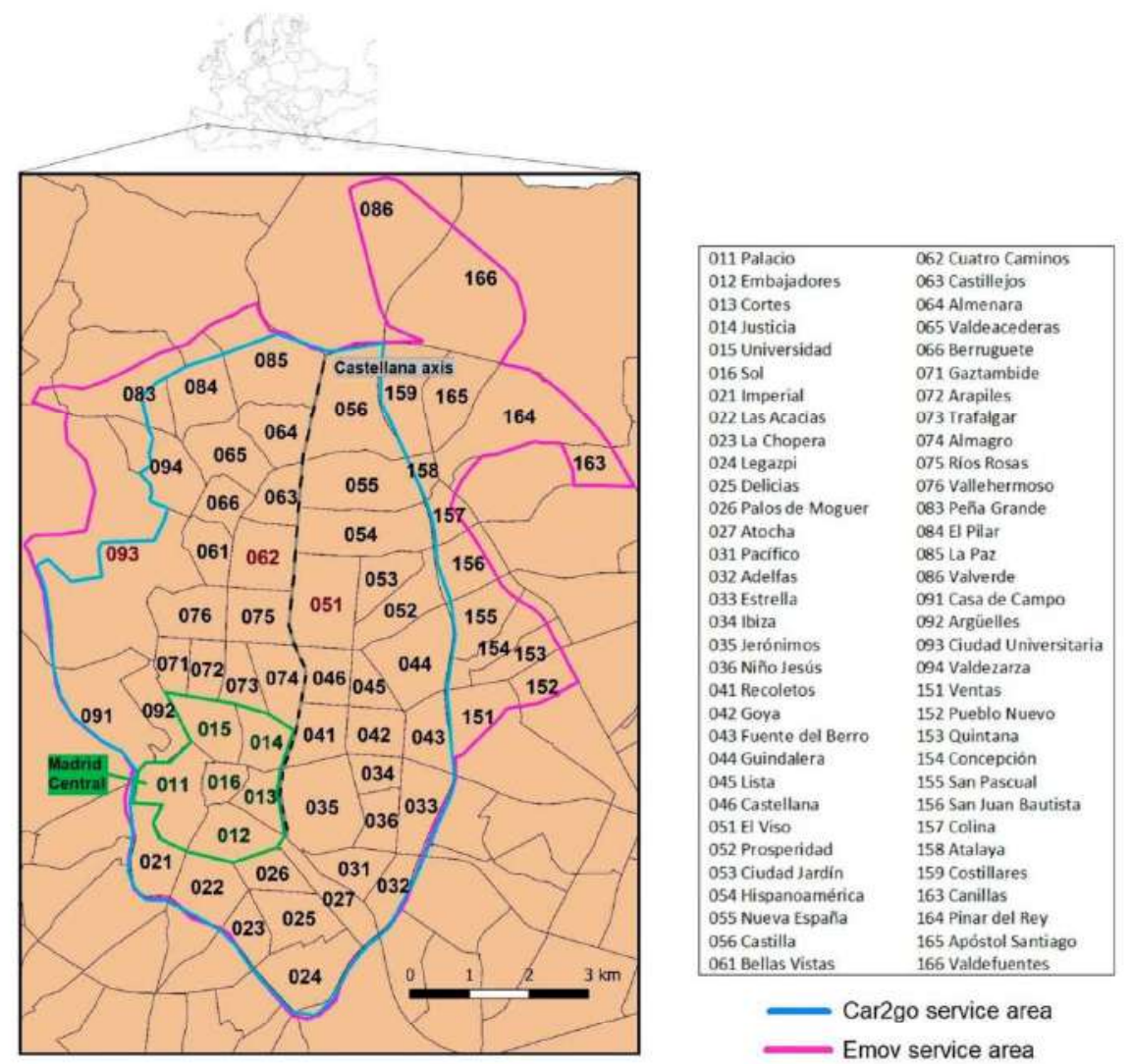

Figure 1. Madrid neighborhoods and free-floating carsharing system (FFCS) service zones (the numbering of the zones correspond to the official codes used by the Madrid City Council).

\subsection{Methodology}

The first step of the methodology was the design of a platform, called CarTrack, in which two crawlers were built to collect data from the Car2go and Emov websites. The web capture system, CarTrack, was based on a logical architecture that followed JEE (Java Enterprise Edition) design standards and patterns. The hardware used consisted of two interrelated servers that behaved as if they were only one, which integrated two redundant Ubuntu 16.04 virtual machines. The acquisition 
and tracking tool that identified vehicle availability was developed in the Python 3.6 language and Pandas libraries. The acquisition data platform was packaged in a Docker container, an open-source tool that allowed us to perform a light virtualization with which to package environments (operating systems) and applications such as the FFCS data acquisition platform. The tool was launched through Marathon, a Docker director, although it can be run manually. The records were stored in a NO-SQL (no relational structured query language) database, Cassandra version 3.0.14, of high availability and consistency. Figure 2 shows the CarTrack platform interface (zoom settings enable the location of each parked car to be displayed).

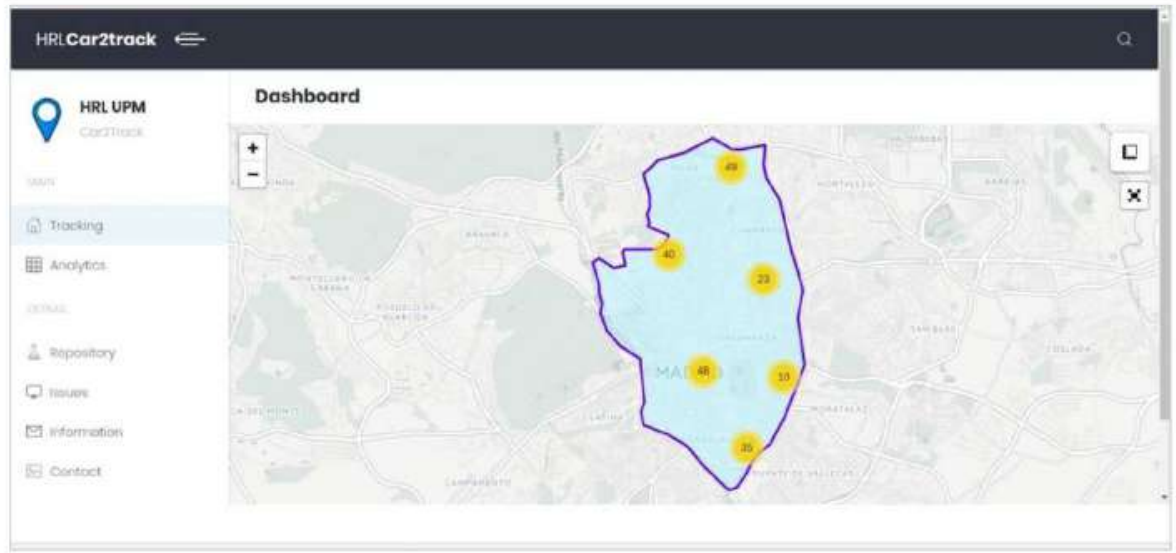

Figure 2. Display of the interface of the CarTrack platform.

Taking into account that only available cars in the website could be tracked, the platform was able to register the position (latitude, longitude, and address), identification, and energy status of the available and on-street parked FFCS cars. The data acquisition service gathered data every 30 seconds. The period selected for the data used in this study (and for the completion of the final database)) was between 28 November, 2017 and 12 April, 2018. Although data were collected for a more extended period of time, the months that were finally selected corresponded with proper platform functioning, once the operational problems were finally overcome in the pilot stage of CarTrack.

CarTrack created a record each time a car disappeared from the interface and this record ended when the FFCS car appeared again, usually corresponding to a trip. We use the term "usually" because in most of the cases, when the trip ended and the user closed the car, the car became available again for other users (as long as it is above the minimum battery level), but there were some exceptions that should be filtered before analysis. For example, someone could have booked a car without making a trip: the car was booked but not rented in the end (the car was unavailable for some minutes, but the trip should not be registered). The cleaning of the database under specific criteria for the FFCS operation in Madrid was necessary, and the definition of these criteria would allow the identification of real trips (rentals), excluding electric charging, maintenance or cleaning operations, or connectivity problems that make the car be temporarily out of service.

Criteria for identifying trips started with the discrimination between bookings and rentals. Bookings were made of all the records in which the car was unavailable, whether a trip takes place or not. Rentals consisted of all the bookings excluding all trips with no movement. Trips with no movements were identified because their origin and destination neighborhoods were the same and their car battery consumption was null. Therefore, rentals fulfilled one of the following requirements: they started and ended in different neighborhoods, and the battery level at the end of the trip was lower than the initial battery level, or both. In order to be discarded, staff trips for electric charging (car2go and Emov fleets are totally electric) were identified together with maintenance, cleaning, and 
relocation tasks, which are usually performed at the same time. The criteria to exclude these trips were based on information of the car battery status. When a car had a discharged battery (below the minimum required level) and taken by the operator to charge it, the car was out of service until it had been charged and relocated and could be erroneously counted as a trip. To avoid it, those records whose battery levels were higher at the end than at the beginning were removed. These electric cars must be charged between once a day and once every two days because of their limited autonomy and their high utilization rate. Besides, maintenance and cleaning tasks can be performed in the meantime and, since they use fast chargers, it is estimated to take only $5 \%$ of the daily total time.

\section{Results and Discussion}

Once the database was cleaned and the identification of rentals was carried out, the research focused on temporal distribution of trips. Before obtaining aggregated figures, days with unique behaviors were removed from the database (Easter holidays, Christmas and other national, regional, or local holidays). The remaining days were categorized by day of the week to obtain the average daily profile by type of day. Figure 3 shows the average daily evolution of rentals made every hour categorized by day of the week.

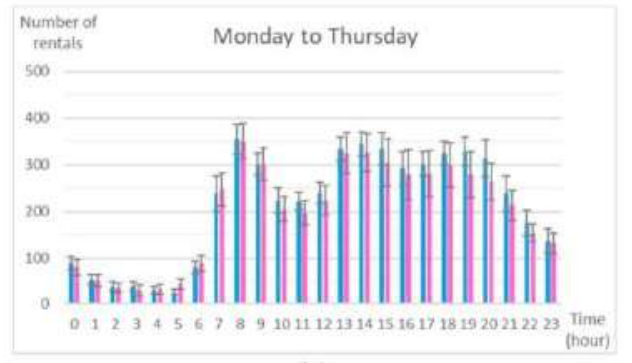

(a)

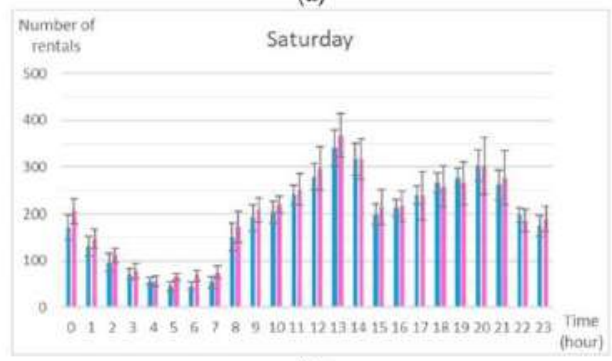

(c)

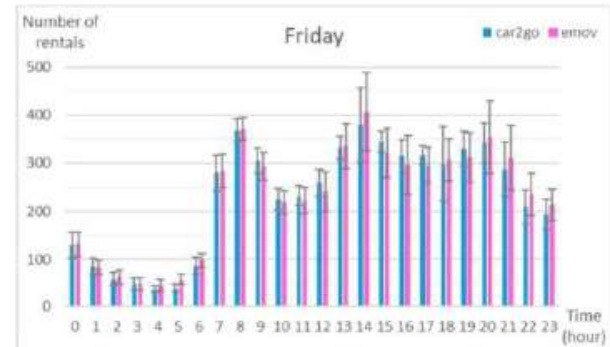

(b)

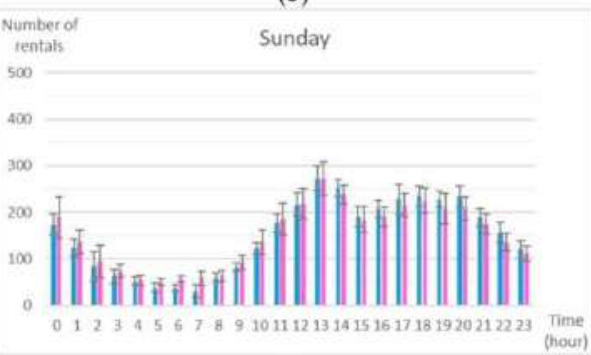

(d)

Figure 3. Average number of rentals per day of the week in Madrid: (a) Monday to Thursday, (b) Friday, (c) Saturday, and (d) Sunday. Standard deviation of each hourly sample is shown.

Both Car2go (in blue) and Emov (in pink) behaved the same way with three rental peaks on weekdays. The first peak started at 7 am but lasted longer than conventional morning rush hour because of the increase in the trip cost during more congested periods (until 9:59 am). The second one began around $1 \mathrm{pm}$ and it distinguished Madrid from other cities without this peak at lunchtime as stated by Habibi et al. [15]. When people return home or go to spare time activities (from $6 \mathrm{pm}$ ), the third peak occurred. The distribution of trips on weekends had only two peaks: before lunchtime and in the evening, indicating that the use was different, mainly for leisure activities.

The data obtained also allowed us to carry out a spatial analysis of the origin-destination flows of travel in the FFCS. In order to assess the data in spatial units as homogeneously as possible, administrative delimitation in neighborhoods was chosen. Figure 4 represents the aggregate number of 
trips that took place in each neighborhood throughout the period analyzed (coding is the one indicated in Figure 1).

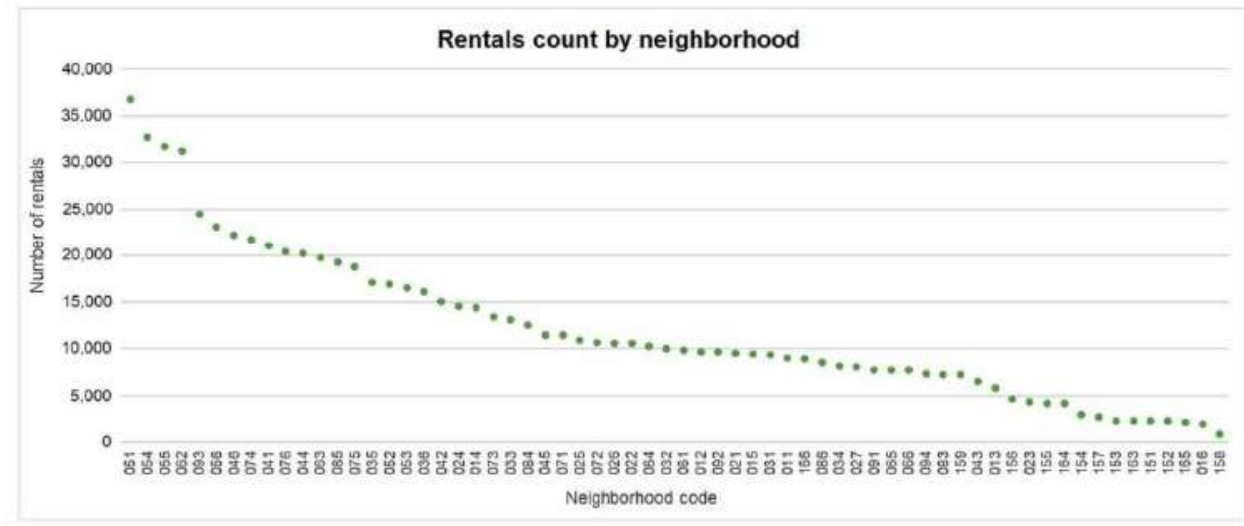

Figure 4. Number of rentals per neighborhood in the whole period analyzed.

The results show that the most frequent trips occurred to and from neighborhoods located in the northern half of the Central Almond, concentrated near the north-south axis of Paseo de la Castellana. The only exception within the top ones is Ciudad Universitaria (093), a neighborhood placed on the Norwest limit of the Central Almond where the main university campus of the city is located. On the other hand, the districts with the lowest volume of trips were those located on the outskirts (mainly, districts 15 and 16), that is to say, residential areas farther from the points of interest, where only one of the analyzed companies operates. Also, some neighborhoods of the central district (01) were among the last positions due to the difficulties for parking in this area before the implementation of Madrid Central and to the high supply of other transportation modes.

When exploring trip flows, we found that among the most frequent OD pairs (Origin-Destination pairs) were those that had an origin and destination in the same neighborhood. It is worth remembering that those records called "bookings", in which the trip starts and ends in the same neighborhood and the battery remains at the same level, were already extracted from the database, so those considered here were real trips since there was battery consumption. However, our database lacked the recorded pathway, so we ignored the proportion of those trips which were internal within the neighborhood against those in which the vehicles travelled to another point in the city and then returned to the point of origin during the same reservation. Figure 5 shows that trips of shorter duration were more likely to have an origin and destination in the same neighborhood, indicating that the trend would lean towards "intra-neighborhood" trips. The indicated duration included the entire period of time: from the moment when the car reservation took place until the car was closed after the end of the trip.

Notwithstanding the above, although they were among the most frequent pairs, trips with an origin and destination in the same neighborhood represented a small proportion of total trips: $12.7 \%$ of trips lasting up to $15 \mathrm{~min}$ and only $3.9 \%$ of trips of longer duration. For this reason, the authors decided to delve into the flows that took place from one neighborhood to another, without displaying the trips that begin and finish in the same neighborhood. 


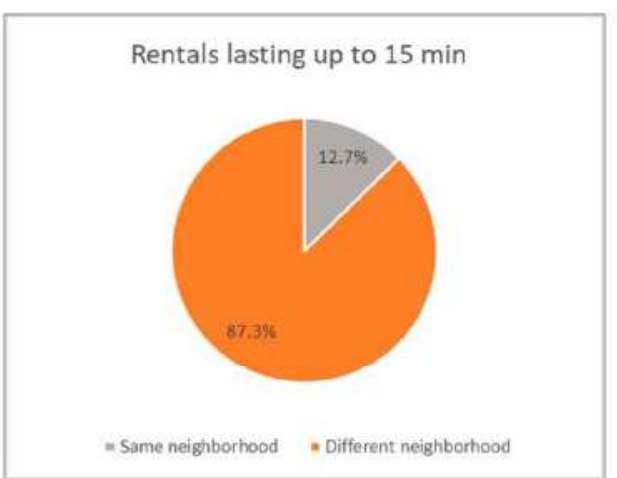

(a)

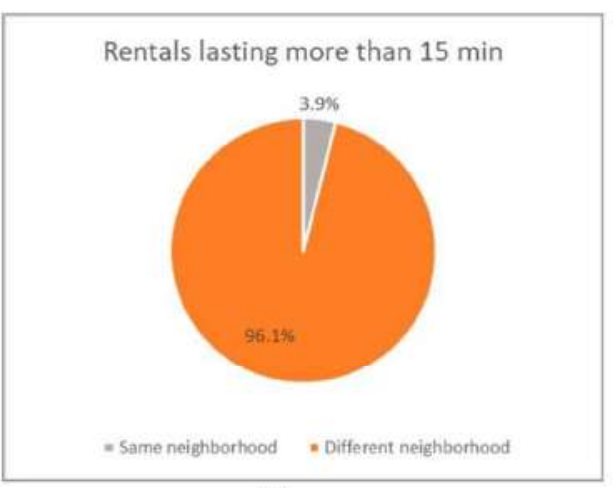

(b)

Figure 5. Proportion of trips with an origin and destination in the same neighborhood versus in different neighborhoods in rentals (a) lasting up to 15 minutes and (b) lasting more than 15 minutes.

With the aim of further analyzing these flows and taking into account the differences shown according to the duration, FFCS trips were disaggregated into three groups: trips lasting less than 15 minutes or equal, trips lasting between 16 and 30 minutes, and trips lasting more than 30 minutes. This type of disaggregation has been used by other authors $[15,25]$. The frequency distribution and the most frequent origin-destination pairs of each group can be seen in Figure 6. Additionally, three time slots were split off-morning, afternoon, and evening peaks - in order to highlight the periods of greatest demand throughout a weekday as indicated in Figure 3.

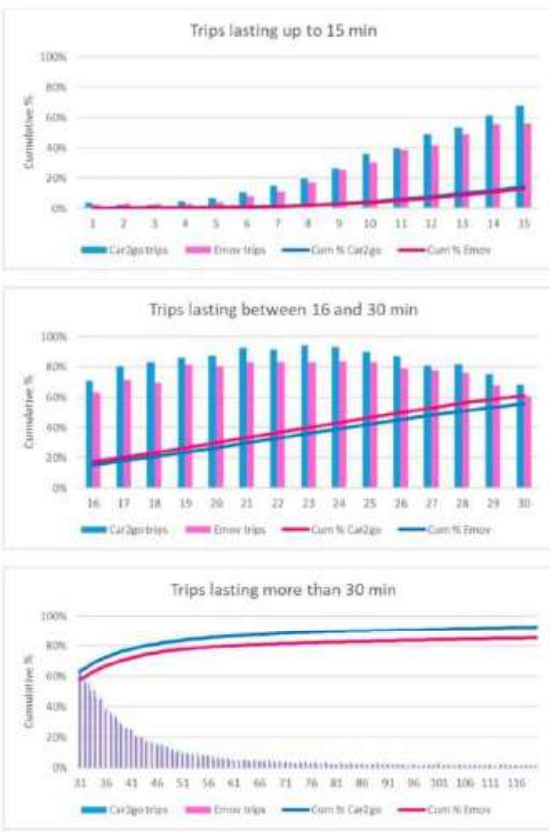

(a)

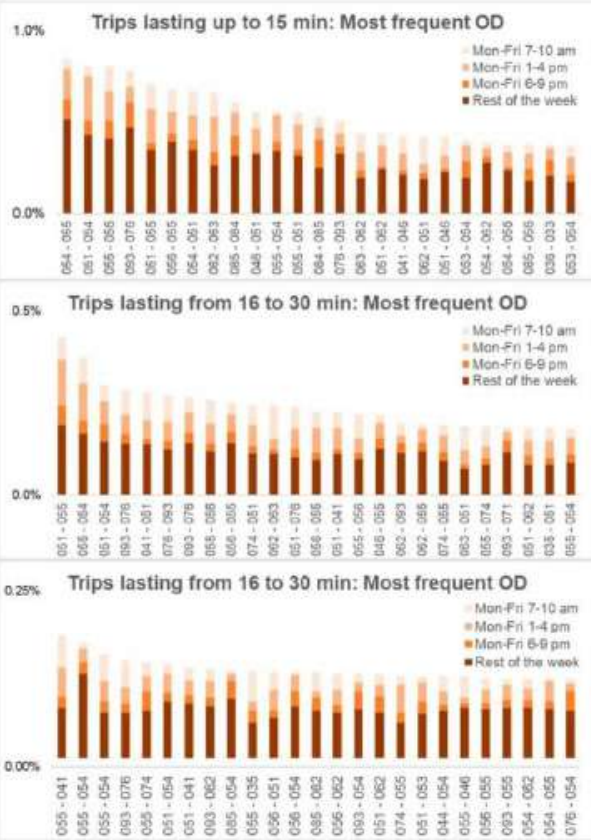

(b)

Figure 6. (a) Frequency of FFCS trips attending the total rental time and (b) most frequent origin-destination pairs according to rental duration. Pairs with an origin and destination in the same neighborhood were excluded. 
The first group consisted of rentals that lasted up to 15 minutes including both the booking time and the trip itself. In the case of the Madrid FFCS, the maximum booking time was 20 minutes, but the average booking time was around 8 minutes [6] which led to a reduced trip time. Nevertheless, within this group, practically $20 \%$ of the total trips were included. Due to the fact of their shorter duration, these trips were made between very close neighborhoods, and their repetition frequency was relatively high (approximately $0.9 \%$ of the trips of this group were in the most frequent origin-destination pairs).

More than $40 \%$ of the records were grouped in a duration period between 15 and 30 minutes. This group represents the most likely behavior of trips: the average duration of the entire database was 27 minutes, although the mode was slightly shorter ( 23 minutes). The dispersion of origin-destination flows was greater than in the previous group as can be seen by the lower frequency of those shown in the graph.

Finally, the third group was formed by those rentals lasting 30 minutes or more. Records with a duration period up to 120 minutes are included in the graph, but there is still a remaining group with a longer duration: over $15 \%$ of Emov trips and almost $6 \%$ of Car2go ones. This difference was due to the affordable daily rental rates offered by Emov at the time of data acquisition. The dispersion of this group was not only produced in duration but also in the variety of possible origins and destinations. Although it is true that there were trips between farther neighborhoods among the most frequent, each of them only represented approximately $0.20 \%$ of the trips of this group.

Regarding the division of graphs into time slots, we found that, although there was variability, around $50 \%$ of trips between the most frequent pairs occurred in the three peak periods indicated. Each of them lasted 3 hours a day, from Monday to Friday, so we can say that half of the trips between the most frequent pairs occurred in $27 \%$ of week time. This premise was fulfilled by the three groups according to trip duration.

Three neighborhoods that were among the most frequent origins and destinations in the previous graphs were selected in order to develop a more disaggregated analysis: El Viso (051), Ciudad Universitaria (093), and Cuatro Caminos (062) (coding as the one indicated in Figure 1). The peculiarities that make them generate and attract a larger number of trips are be detailed below, as well as the distribution of vehicles at the time of trip beginning. Figure 7 depicts the hourly distribution in an average working day of the trips originating in each neighborhood and the starting positions of the trips. In addition, some socioeconomic indicators of these neighborhoods are shown and compared with the Central Almond districts average and the municipality of Madrid average (Table 1).

Table 1. Socioeconomic variables of the analyzed neighborhoods compared to the average indicators of Madrid Municipality. Source: Madrid City Council.

\begin{tabular}{|c|c|c|c|c|c|}
\hline & $\begin{array}{l}\text { El Viso } \\
\text { (051) }\end{array}$ & $\begin{array}{c}\text { Ciudad } \\
\text { Universitaria (093) }\end{array}$ & $\begin{array}{c}\text { Cuatro } \\
\text { Caminos (062) }\end{array}$ & Districts $01-07$ & $\begin{array}{c}\text { Madrid } \\
\text { Municipality }\end{array}$ \\
\hline Area (ha.) & 170.92 & 1425.09 & 118.5 & 4178 & $60,445.52$ \\
\hline Population (inhabitants) & 17,145 & 16,097 & 34,254 & 988,817 & $3,221,824$ \\
\hline $\begin{array}{l}\text { Population density } \\
\text { (inhabitants/ha) }\end{array}$ & 100.31 & 11.30 & 289.05 & 236.68 & 53.30 \\
\hline Gender: Women/Men (\%) & $54.7 / 45.3$ & $54.6 / 45.4$ & $54.9 / 45.1$ & $54.3 / 45.7$ & $53.4 / 46.6$ \\
\hline Age groups: & $13 / 17 / 21 /$ & $12 / 17 / 19 /$ & $10 / 16 / 25 /$ & $11 / 15 / 25 /$ & $14 / 15 / 23$ \\
\hline $\begin{array}{c}0-14 / 15-29 / 30-44 / \\
45-64 / 65+\text { years old }(\%)\end{array}$ & $28 / 21$ & $26 / 25$ & $26 / 23$ & $27 / 22$ & $28 / 20$ \\
\hline $\begin{array}{c}\text { Population with university } \\
\text { studies (\%) }\end{array}$ & 50.0 & 49.8 & 42.8 & 42.8 & 28.6 \\
\hline Households (number) & 6,060 & 6,103 & 14,866 & 427,246 & $1,278,258$ \\
\hline $\begin{array}{l}\text { Average annual income } \\
\text { per household }(€)\end{array}$ & 103,573 & 67,390 & 43,306 & 45,389 & 38,535 \\
\hline $\begin{array}{l}\text { Quality of life in the } \\
\text { neighborhood }(0-100)^{1}\end{array}$ & 81.6 & 79.7 & 66.8 & 74.64 & 69.5 \\
\hline
\end{tabular}

${ }^{1}$ Source: 2017 Madrid City Council survey. 


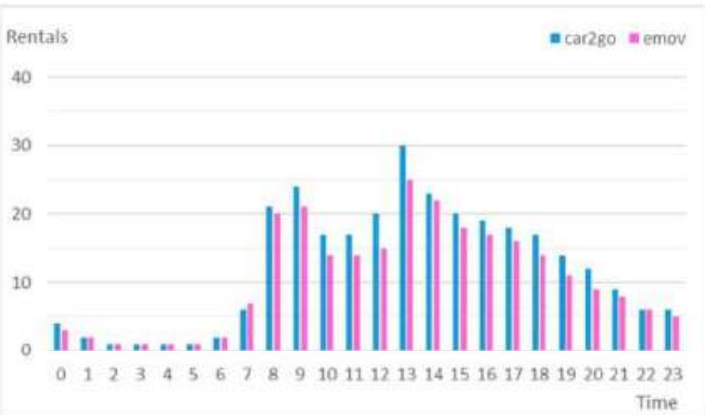

(a)

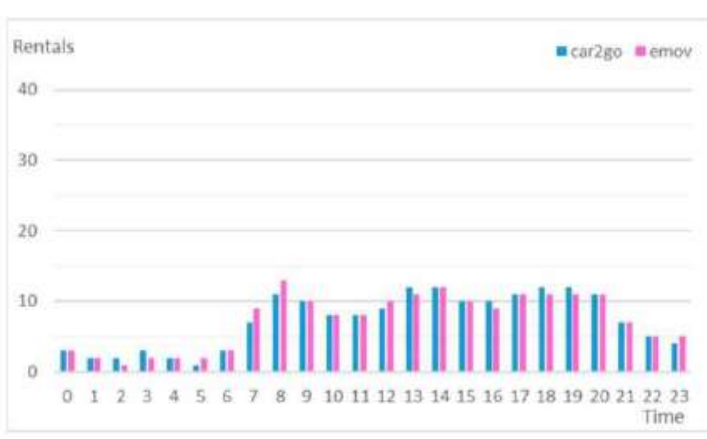

(b)

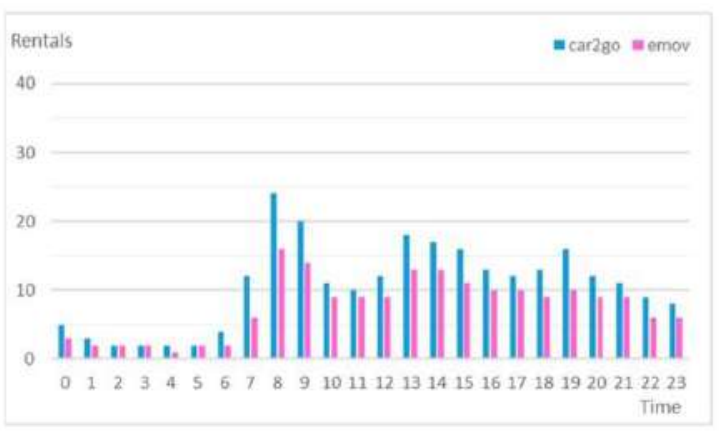

(c)
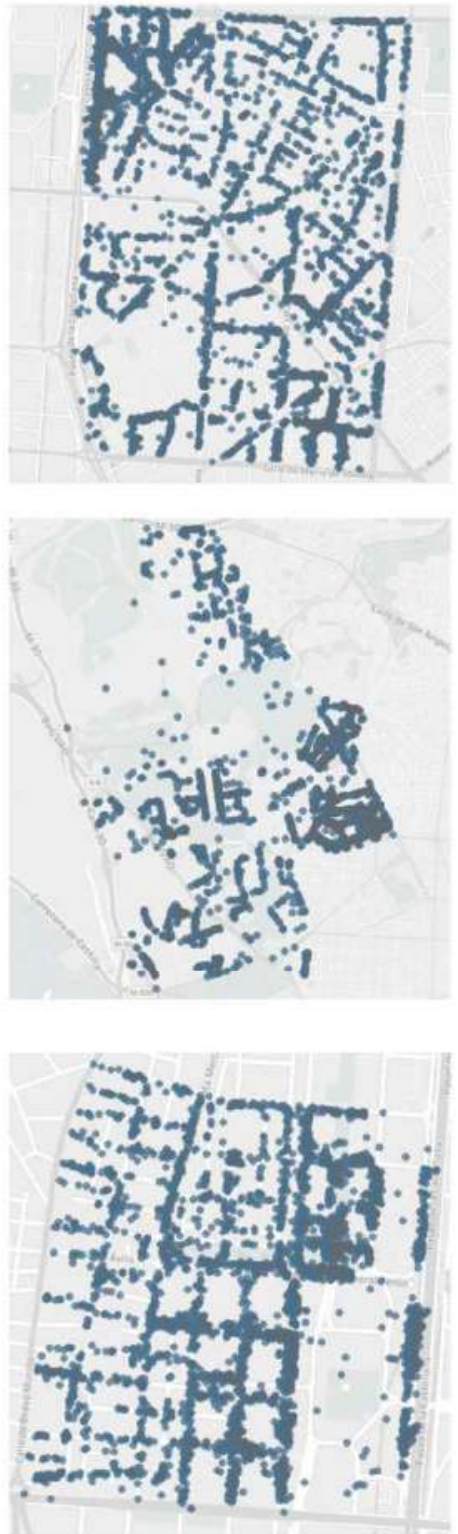

Figure 7. Average distribution of trips on weekdays and location of trips origins in the whole period in (a) El Viso-051, (b) Ciudad Universitaria—093, and (c) Cuatro Caminos—062.

El Viso is a neighborhood belonging to the Chamartin district. It is mostly a residential neighborhood with detached houses, something uncommon within the Central Almond of Madrid. For this reason, the population density is lower than in other neighborhoods (100 inhabitants/ha, compared to 158 inhabitants/ha on average in its district and 237 inhabitants/ha on average in the districts belonging to the Central Almond) [30]. This implies that there is low demand for parking by residents' vehicles and a lot of space available for FFCS vehicles. Their households have one of the highest average incomes in the city $(€ 103,573)$ which considerably exceeds the average of the districts of the Central Almond $(€ 45,389)$ and the entire city $(€ 38,535)$, which could lead to a higher 
willingness to pay. Besides this, it is located near important points of interest of the city placed in Paseo de la Castellana, business areas like Azca, or Public Administration buildings like Nuevos Ministerios. This makes El Viso attractive to FFCS users due to the fact of its parking availability, even if the final destination of the trip is not in the neighborhood itself but in nearby places.

On the other hand, Ciudad Universitaria is in Moncloa-Aravaca district. It hosts the most important university campus in the city in its southern area which bears the same name. This area is characterized by university buildings as well as extensive green areas. There is also a large supply of parking areas, either next to the buildings or on public roads, and it is well connected by car with other areas of the city through the M-30 ring road despite not being a central area. However, most trips originated or had a destination in the east side of the neighborhood where student residences and apartment buildings are located. Despite its great extension, this neighborhood only has a population of 16,097 registered inhabitants [30], but the official figures do not include the students who reside here and who are potential users of the FFCS systems, as they are young people, with a driving license and, in most cases, without own vehicle [6]. Additionally, there is a lack of public transportation supply that connects it with other points of attraction in the city which makes FFCS vehicles convenient. Attending to the average trip distribution over a working day, the curve was smoother than in the entire city, indicating that trips occur equally throughout the day.

Finally, the third neighborhood analyzed was Cuatro Caminos which belongs to Tetuan district. It is an area with higher population density ( 289 inhabitants/ha) and lower average income per household than the previous ones $(€ 43,306)$, although it is still above the city average $(€ 38,535)$. Despite being a neighborhood with high population, one of the main business hubs is found in the eastern part of the neighborhood next to Paseo de la Castellana. It is precisely in the on-street parking space of this area where more FFCS cars are parked. The distribution of trips in Cuatro Caminos is similar to that of the entire city, with three peaks throughout a weekday. The first rush hour corresponds to the trips made by the residents in the neighborhood, and those that occur at lunchtime and in the evening correspond to the intense activity of the offices located here.

To sum up, we clearly see how the main points generating and attracting FFCS trips corresponded to predominantly residential neighborhoods with low population density and high income, that a priori would not constitute the traditional nodes of generation of public transport trips. We consider that these districts are not really the trip origins or destination themselves, but thanks to its privileged location near points of attraction (company and public administration headquarters or commercial areas) and near big public transport stations, many users may choose it for its parking availability, although FFCS is only one stage of their trip chain. Although the operators' APIs are the best source of data we currently have, we are neglecting the real origins and destinations of the trips. Therefore, we emphasize the idea that this kind of data should be analyzed with caution and should not be used to draw conclusions without knowing the particularities of the place.

After displaying the situation in these three neighborhoods, where there is a high sample of trip origins and destinations, it is worth highlighting the importance of the on-street parking characteristics in the performance of FFCS. Parked vehicles tend to group on main streets, which are well connected and where, of course, there is parking supply.

\section{Conclusions}

The authors deepened the understanding of FFCS operation in the city of Madrid by analyzing temporal and spatial dimensions of the most frequent trips. Data extracted from the websites of the two most established operators in the city during more than four months were used for this purpose. An acquisition platform was designed to collect and archive the available data on both websites in real time. Data processing techniques were applied subsequently with the necessary criteria to identify the records corresponding to real user trips. This research shows that reconstructing trips from booking data by using big data platforms is not an automatic task, as stressed previously Müller et al. [11], 
and more research is needed in this area. It would also be convenient to reproduce this study in other cities to make the analysis more robust and check the correct performance of the platform.

The presentation of the most important findings of this research was made from a general to a specific level. Firstly, the temporal profile of trips was shown, highlighting the peculiarities that make the distribution of trips throughout the day different from other cities due to the habits of citizens. Madrid follows the profile defined by Habibi et al. [15] in a previous study. Then, the travel sample was classified according to its duration, pointing out the differences of each cluster, and it was proven that the longer the trip, the more likely it is to be between more distant points.

Regarding the spatial dimension, an analysis of the city level was carried out at a general level of the city, ranking the neighborhoods based on the rentals made in them. Three neighborhoods, among the most frequent origin and destinations, were selected in order to develop a spatial unit level analysis After detailing its peculiarities, it can be concluded that more trips were generated and attracted in higher income areas with low population density, high on-street parking availability, and, especially, good connection to the public network and to the main labor and commercial centers.

The decisions driven by the cities policy makers, not only in terms of mobility but also in urban planning and design, strongly impact on the success of emerging forms of mobility such as FFCS. Parking regulations and public transport policies affect the continuity and success of this new transportation mode. Future lines of research should focus on the user profile in order to define the real origin and destination of the trips, and web-based data will not be enough to accomplish this task; survey campaigns and/or FFCS members' data from companies will be necessary. This idea was already underlined by Cocciola et al. [12]. Moreover, a detailed information of the current utilization of on-street parking is necessary in order to prioritize the type of vehicle and user that Public Administrations wants to favor, e.g., electric vehicles, district resident users, carsharing users, disable people. Marketing campaigns should back FFCS systems because there is a need to educate and increase people's awareness of electric vehicles and shared mobility systems. Educating drivers may be challenging since there may be little time to train carsharing clients and social inequities should be avoided. There are only a few papers in the literature dealing with the acceptance to FFCS [31,32], and more research is needed. Finally, the implementation of new low-emission areas (like Madrid Central) will need a detailed analysis with the aim of studying its impacts on the environment and the congestion of the city.

Although it is not proven that FFCS has the positive effects generated by traditional carsharing in terms of reduction of owned vehicles and vehicle-kilometers travelled, City Councils should promote its usage in a complementary way to public transport. There is no doubt that in Madrid, with electric vehicle fleets, FFCS are having a positive impact on the environment. However, congestion reduction involves raising public awareness of not relying on their private vehicles and using more public transport combined with other sustainable transportation modes.

Author Contributions: Conceptualization, M.A.-R. and B.G.; Methodology, M.A.-R. and B.G.; Software, M.A.-R and R.M.-S.; Validation, B.G. and R.M.-S.; Formal Analysis, M.A.-R. and L.B.; Investigation, M.A.-R., B.G. and L.B.; Resources, M.A.-R., R.M.-S. and B.G.; Data Curation, M.A.-R. and R.M.-S.; Writing-Original Draft Preparation, M.A.-R. and B.G.; Writing-Review and Editing, M.A.-R., B.G. and L.B.; Visualization, M.A.-R., R.M.-S.; Supervision, B.G.; Project Administration, B.G. All authors have read and agreed to the published version of the manuscript.

Funding: This research has not received funding.

Conflicts of Interest: The authors declare no conflict of interest.

\section{References}

1. Ciari, F.; Bock, B.; Balmer, M. Modeling station-based and free-floating carsharing demand: Test case study for Berlin. Transp. Res. Rec. 2014, 2416, 37-47. [CrossRef]

2. Herrmann, S.; Schulte, F.; Voß, S. Increasing acceptance of free-floating car sharing systems using smart relocation strategies: A survey based study of car2go Hamburg. In Proceedings of the International conference on computational logistics, Valparaiso, Chile, 24-26 September 2014; pp. 151-162. 
3. Wielinski, G.; Trépanier, M.; Morency, C. Electric and hybrid car use in a free-floating carsharing system. Int. J. Sustain. Transp. 2015, 11, 161-169. [CrossRef]

4. Kopp, J.; Gerike, R.; Axhausen, K.W. Do sharing people behave differently? An empirical evaluation of the distinctive mobility patterns of free-floating car-sharing members. Transportation 2015, 42, 449-469. [CrossRef]

5. Niels, T.; Bogenberger, K. Booking Behavior of Free-Floating Carsharing Users: Empirical Analysis of Mobile Phone App and Booking Data Focusing on Battery Electric Vehicles. Transp. Res. Rec. 2017, 2650, 123-132. [CrossRef]

6. Ampudia-Renuncio, M.; Guirao, B.; Molina-Sanchez, R. The impact of free-floating carsharing on sustainable cities: Analysis of first experiences in Madrid with the university campus. Sustain. Cities Soc. 2018, 43, 462-475. [CrossRef]

7. Le Vine, S.; Adamou, O.; Polak, J. Predicting new forms of activity/mobility patterns enabled by shared-mobility services through a needs-based stated-response method: Case study of grocery shopping. Transp. Policy 2014, 32, 60-68. [CrossRef]

8. Martin, E.; Shaheen, S. The Impacts of Car2go on Vehicle Ownership, Modal Shift, Vehicle Miles Traveled, and Greenhouse Gas Emissions: An Analysis of Five North American Cities. In Transportation Sustainability Research Center; UC Berkeley: Berkeley, CA, USA, 2016; Volume 3.

9. Firnkorn, J.; Müller, M. What will be the environmental effects of new free-floating car-sharing systems? The case of car2go in Ulm. Ecol. Econ. 2011, 70, 1519-1528. [CrossRef]

10. Firnkorn, J. Triangulation of two methods measuring the impacts of a free-floating carsharing system in Germany. Transp. Res. Part A: Policy Pract. 2012, 46, 1654-1672. [CrossRef]

11. Müller, J.; Correia, G.; Bogenberger, K. An explanatory model approach for the spatial distribution of free-floating carsharing bookings: A case-study of German cities. Sustainability 2017, 9, 1290. [CrossRef]

12. Ciociola, A.; Cocca, M.; Giordano, D.; Mellia, M.; Morichetta, A.; Putina, A.; Salutari, F. UMAP: Urban mobility analysis platform to harvest car sharing data. In Proceedings of the 2017 IEEE SmartWorld, Ubiquitous Intelligence \& Computing, Advanced \& Trusted Computed, Scalable Computing \& Communications, Cloud \& Big Data Computing, Internet of People and Smart City Innovation, San Francisco, CA, USA, 4-8 August 2017; pp. 1-8.

13. Zhang, C.; He, J.; Liu, Z.; Xing, L.; Wang, Y. Travel demand and distance analysis for free-floating car sharing based on deep learning method. PLOS ONE 2019, 14, e223973. [CrossRef]

14. Ampudia-Renuncio, A.; Guirao, B.; Molina Sánchez, R.; Engel de Âlvarez, C. Understanding the spatial distribution of free-floating carsharing in cities: Analysis of the new Madrid experience through a web-based platform. Cities 2020, 98, 102593. [CrossRef]

15. Habibi, S.; Sprei, F.; Englundn, C.; Pettersson, S.; Voronov, A.; Wedlin, J.; Engdahl, H. Comparison of free-floating car sharing services in cities. Eur. Counc. Energy Effic. Econ. Summer Study 2017, 2017, 771-778.

16. Loose, W. The state of European car-sharing. Proj. Momo Final Rep. D 2010, 2, 1-129.

17. Wilke, G. Explaining mobility through milieu membership: Analyses of the validity of milieu concepts using the example of car-sharing. Subj. Oriented Approaches Transp. Dortm. Inst. Fiir Raumplan. 2009, 24-39.

18. Shaheen, S.A.; Cohen, A.P. Growth in worldwide carsharing: An international comparison. Transp. Res. Rec. 2007, 1992, 81-89. [CrossRef]

19. Haefeli, U.; Matti, D.; Schreyer, C.; Maibach, M. Evaluation Car-Sharing. Fed. Dep. Environ. Transp. Energy Commun. Bern 2006, 1-107.

20. Shaheen, S.A.; Cohen, A.P.; Chung, M.S. North American carsharing: 10-year retrospective. Transp. Res. Rec. 2009, 2110, 35-44. [CrossRef]

21. Martin, E.; Shaheen, S.A. Greenhouse Gas Emission Impacts of Carsharing in North America. IEEE Trans. Intell. Transp. Syst. 2011, 12, 1074-1086. [CrossRef]

22. Becker, H.; Ciari, F.; Axhausen, K.W. Comparing car-sharing schemes in Switzerland: User groups and usage patterns. Transp. Res. Part A Policy Pract. 2017, 97, 17-29. [CrossRef]

23. Schmöller, S.; Weikl, S.; Müller, J.; Bogenberger, K. Empirical analysis of free-floating carsharing usage: The Munich and Berlin case. Transp. Res. Part C Emerg. Technol. 2015, 56, 34-51. [CrossRef]

24. Wielinski, G.; Trépanier, M.; Morency, C. Exploring Service Usage and Activity Space Evolution in a Free-Floating Carsharing Service. Transp. Res. Rec. 2019, 2673, 36-49. [CrossRef] 
25. Sprei, F.; Habibi, S.; Englund, C.; Pettersson, S.; Voronov, A.; Wedlin, J. Free-floating car-sharing electrification and mode displacement: Travel time and usage patterns from 12 cities in Europe and the United States. Transp. Res. Part D Transp. Environ. 2019, 71, 127-140. [CrossRef]

26. Ayuntamiento de Madrid. Ordenanza de Movilidad para la Ciudad de Madrid. Available online: https://www.madrid.es/UnidadesDescentralizadas/UDCMovilidadTransportes/SER/Ficheros\%20nuevo\% 20SER\%202014/Ordenanza\%20de\%20Movilidad.pdf (accessed on 23 December 2019).

27. Ayuntamiento de Madrid. Ordenanza Fiscal SER 31-12-2016. Available online: https://sede.madrid.es/ UnidadesDescentralizadas/UDCMovilidadTransportes/SER/Descriptivos/ficheros/Ordenanza\%20Fiscal\% 20SER\%2031-12-2016.pdf (accessed on 23 December 2019).

28. Ayuntamiento de Madrid. Ordenanza de Movilidad Sostenible. Available online: https://sede.madrid.es/ FrameWork/generacionPDF/ANM2018_45.pdf?idNormativa $=5$ ccdb732cef96610VgnVCM2000001f4a900aRCRD\& nombreFichero=ANM2018_45\&ccacheKey=212 (accessed on 23 December 2019).

29. Anas Ahmed, S. What Has Been the Impact of Madrid Central on Road Usage and Emissions Since Its Implementation in November 2018? Available online: https:/www.academia.edu/38808618/What. has_been_the_impact_of_Madrid_Central_on_road_usage_and_emissions_since_its_implementation_in_ November_2018 (accessed on 23 December 2019).

30. Portal de Datos Abiertos del Ayuntamiento de Madrid. Available online: https://datos.madrid.es/portal/site/ egob (accessed on 26 December 2019).

31. Namazu, M.; MacKenzie, D.; Zerriffi, H.; Dowlatabadi, H. Is carsharing for everyone? Understanding the diffusion of carsharing services. Transp. Policy 2018, 63, 189-199. [CrossRef]

32. Wang, $Y$; Yan, $X$; Zhou, Y.; Xue, Q.; Sun, L. Individuals' acceptance to free-floating electric carsharing mode: A web-based survey in China. Int. J. Environ. Res. Public Health 2017, 14, 476. [CrossRef]

(C) 2020 by the authors. Licensee MDPI, Basel, Switzerland. This article is an open access article distributed under the terms and conditions of the Creative Commons Attribution (CC BY) license (http://creativecommons.org/licenses/by/4.0/). 


\section{BLOQUE V. ANÁLISIS DE LOS RESULTADOS}

\section{V.1. ANÁLISIS DE LOS TRABAJOS PRELIMINARES EN UN BARRIO DE LA CIUDAD}

En la fase inicial de esta investigación, se comenzó analizando el impacto del FFCS en una pequeña zona de la ciudad: el campus de Ciudad Universitaria.

En la figura 6 se representa la evolución de los coches Car2go disponibles a lo largo de la semana en la que se programó la captura de instantáneas cada 30 minutos de la página web del operador Car2go, con detalle de los patrones que se produjeron en determinados días.
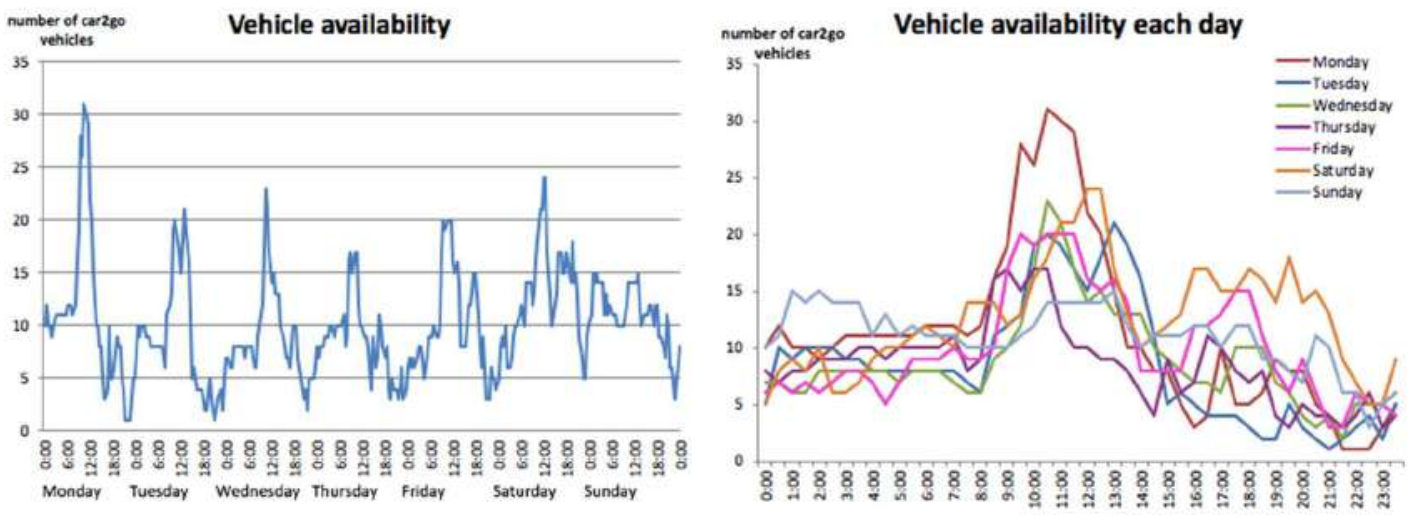

Figura 6. Evolución de la disponibilidad de los vehículos Car2go en Ciudad Universitaria en la semana del 3 al 9 de octubre de 2016: (a) Representación de toda la semana, (b) Representación de los días de la semana superpuestos.

En las observaciones se identificó que el lunes fue el día con la mayor disponibilidad (con un máximo de 32 vehículos en el campus, registrado a las 11:00), mientras que el domingo fue el día con la menor disponibilidad media. En términos generales, el máximo de disponibilidad de cada día se produjo en el periodo comprendido entre las 10 y las 12 de la mañana, indicando que el mayor volumen de vehículos llegó al campus después de la hora punta de la mañana. Debido a que las tarifas del sistema varían en función del tiempo de viaje, la congestión hace que el sistema sea menos competitivo, lo que hace que si los usuarios tienen flexibilidad, tiendan a evitar horas punta. Los datos de disponibilidad son consistentes con el hecho de que el porcentaje de estudiantes que asiste a clase en turno de tarde es inferior a los que acuden por la mañana. También tiene lógica que las variaciones de la disponibilidad por las noches sean reducidas, puesto que apenas se generan viajes desde o hacia el campus. El análisis de esta información se hizo suponiendo que todos los viajes fueron realizados por usuarios y no se discriminaron aquellos realizados por motivos operativos 0 técnicos de la operadora, puesto que no se disponía de la información ni de los medios para hacerlo, como sí se hizo en una etapa posterior de esta investigación. Con respecto a la campaña de encuestas realizada, su objetivo fue conocer los patrones de 


\section{ANÁLISIS DEL IMPACTO DE LOS SISTEMAS DE FREE-FLOATING CARSHARING EN ENTORNOS URBANOS UTILIZANDO DATOS WEB: APLICACIÓN A LA CIUDAD DE MADRID}

los estudiantes, como potenciales usuarios del sistema, y su percepción de la calidad del servicio en función de la disponibilidad de vehículos. Las opciones de respuesta se definieron para poder comparar los resultados con los de la encuesta realizada por Herrmann, Schulte y Voß (2014) en Hamburgo. Aunque su metodología fue diferente (permitiendo la contestación de un formulario online) y la participación fue inferior (87, frente a los 186 cuestionarios válidos de esta encuesta), se consideró que el estudio de Hamburgo era un punto de referencia para validar nuestros resultados.

Solo el $25 \%$ de la muestra de estudiantes de Madrid había probado el sistema de Car2go, hecho relacionado con el lugar de residencia, ya que más del $75 \%$ de los usuarios vivía en el interior del área de servicio del operador. El número de usuarios se repartía por igual entre los estudiantes que asistían a clase por la mañana y por la tarde. La disponibilidad de vehículo privado para dirigirse al campus en días laborables fue reducida (37\%), también entre los que eran usuarios (40\%), demostrando que este grupo de población es un grupo de usuarios objetivo para estos sistemas. No obstante, de los encuestados con disponibilidad de vehículo, no todos lo usaban normalmente para ir a la universidad y volver a casa ( $20 \%$ del total), mientras que la mayoría de los estudiantes utilizaba transporte público para realizar dichos viajes $(65 \%)$.

En la figura 7 se representan los niveles de disposición a caminar hasta un vehículo disponible y a esperar hasta que haya un vehículo disponible a una distancia tolerable por el usuario, tanto en Madrid como en Hamburgo. También se muestran las tasas de penetración de algunas estrategias de recolocación propuestas a los encuestados de ambas ciudades. Las gráficas de la parte inferior de la figura muestran los resultados de la distancia a caminar y el tiempo a esperar máximos en Madrid, desagregados por usuarios y no usuarios. 
(a) Madrid

Accepted maximum distance to car

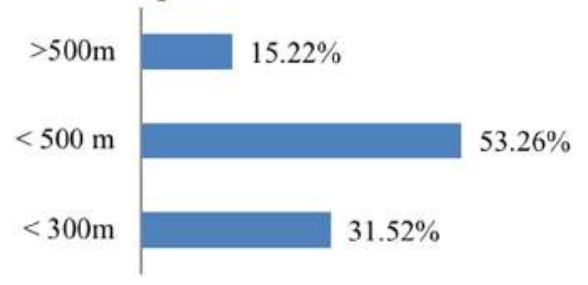

Accepted maximum waiting time

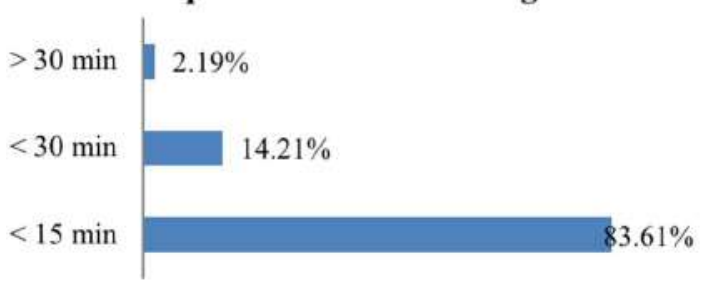

Book a more distant car for a $30 \%$ price reduction
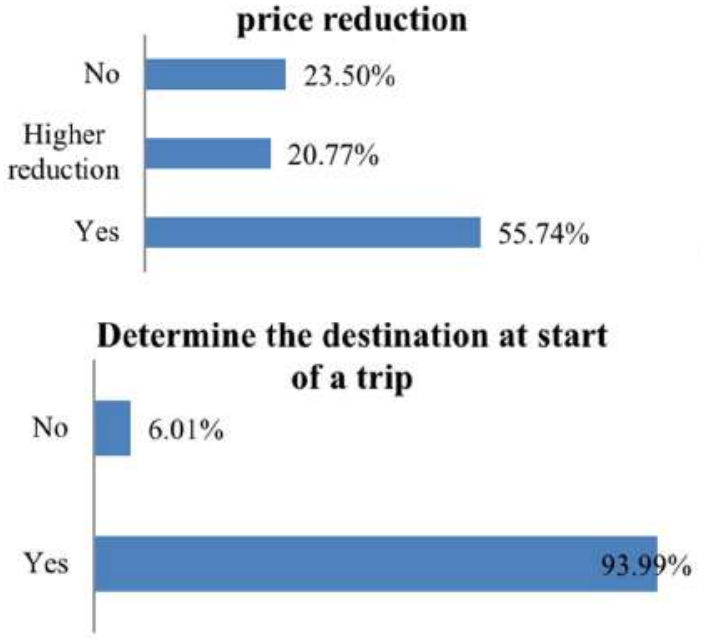

(b) Hamburgo

Accepted maximum distance to car

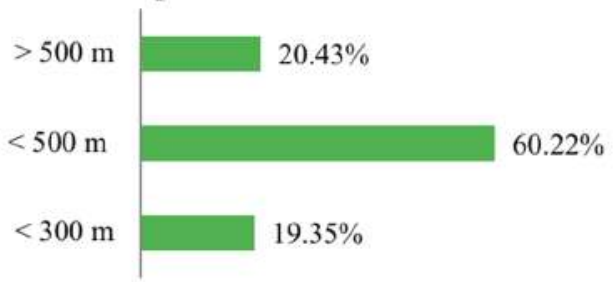

Accepted maximum waiting time

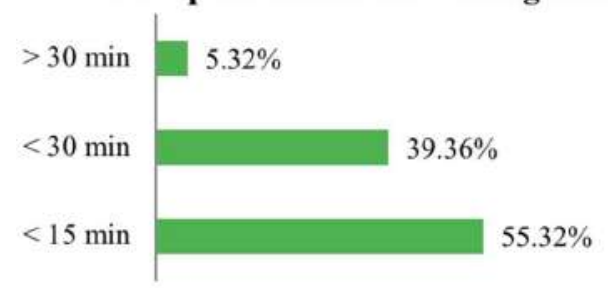

Book a more distant car for a $30 \%$
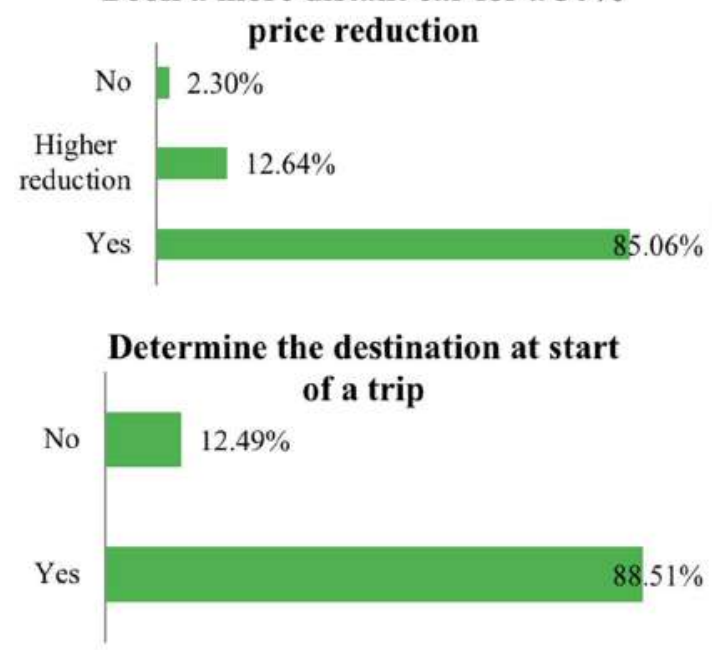

(c) Usuarios y no usuarios en Madrid

Accepted max. distance to car

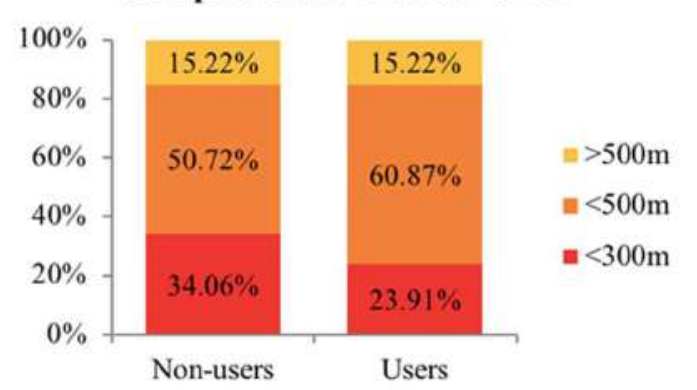

Accepted max. waiting time

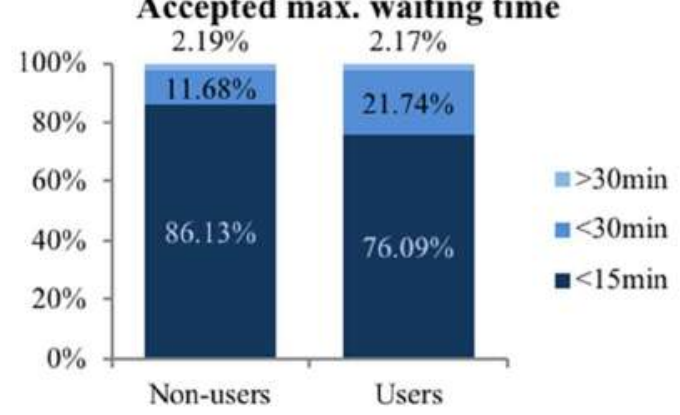

Figura 7. Resultados de la encuesta realizada, comparados con una encuesta similar llevada a cabo en Hamburgo. Aceptación de la disponibilidad y de las estrategias de recolocación de vehículos de los encuestados en (a) Madrid y (b) Hamburgo. (c) Aceptación de la disponibilidad de usuarios y no usuarios en Madrid. 


\section{ANÁLISIS DEL IMPACTO DE LOS SISTEMAS DE FREE-FLOATING CARSHARING EN ENTORNOS URBANOS UTILIZANDO DATOS WEB: APLICACIÓN A LA CIUDAD DE MADRID}

En ambas ciudades, la distancia límite de caminar hasta un vehículo se sitúa en 500 $\mathrm{m}$, por encima de la cual más de un $80 \%$ de los encuestados no alquilaría un vehículo de FFCS, aunque hay distintos niveles de tolerancia. En Madrid, un porcentaje mayor no usaría este sistema si no hubiera vehículos disponibles en un radio de $300 \mathrm{~m}$ : $31.5 \%$, frente a $19.4 \%$ en Hamburgo. Esto es, la disposición a aceptar una distancia mayor es superior en Hamburgo. De igual forma, los resultados del tiempo máximo de espera indican que en torno al $95 \%$ de ambas muestras no aceptarían tener que esperar más de media hora, aunque los encuestados en la ciudad alemana muestran mayor tolerancia: $55.3 \%$ esperaría como máximo 15 minutos, mientras que en Madrid esta cifra asciende a $83.6 \%$. Cuando se alcanza su límite máximo de tiempo sin haber encontrado un vehículo disponible, el individuo decide utilizar un modo de transporte alternativo que, en ambas ciudades, sería el transporte público (más del $80 \%$ de los encuestados así lo indicaron). Este hallazgo es consistente con la hipótesis de que ambos modos de transporte son sustitutivos: un usuario de FFCS utilizará transporte público cuando la calidad del servicio del FFCS (disponibilidad) sea mala, y viceversa, cuando así lo sea la calidad del servicio del transporte público (p.ej., frecuencia).

De la encuesta realizada en Madrid también se deduce una diferencia de comportamiento entre usuarios y no usuarios. Los usuarios tienen niveles de tolerancia ligeramente superiores para alquilar vehículos más distantes o para esperar más tiempo. La confianza en el sistema depende principalmente de la propia experiencia, resultado interesante desde el punto de vista de la estrategia de los operadores cuando ofrecen descuentos o incentivos para captar nuevos usuarios.

En cuanto a las estrategias de recolocación de vehículos, solo la mitad de los usuarios potenciales de Madrid estaría dispuesto a aceptar alquilar un vehículo más distante a cambio de una reducción del $30 \%$ del precio del viaje, mientras que en Hamburgo la proporción ascendía al $85.1 \%$. En cambio, la mayoría de los encuestados de Madrid sí estarían de acuerdo en indicar el destino del viaje al comienzo de este $(94.0 \%$, frente a $88.5 \%$ en Hamburgo), con el fin de que el operador se pudiera anticipar y ofertar un vehículo disponible en una ubicación antes de que éste estuviera en dicho emplazamiento. Con relación al tipo de incentivo preferido, las respuestas difieren entre ambas ciudades: los encuestados en Madrid prefirieron recibir minutos gratis (64.3\%) mientras que, en Hamburgo, la mayoría escogió un descuento en el precio del viaje $(61 \%)$. Esta discrepancia podría estar ligada a las tarifas superiores del servicio de Car2go en Hamburgo.

Con el fin de comparar la tolerancia a caminar declarada por los estudiantes con la disponibilidad de los vehículos en el campus universitario, se contabilizaron los vehículos registrados en las observaciones teniendo en cuenta la distancia a la que se encontraban del centro universitario donde se llevaron a cabo las encuestas. Para ello, se determinaron áreas de influencia concéntricas con radios de 300, 500, 700 y 1000 metros desde la puerta principal de la ETSICCP y se contaron los vehículos disponibles ubicados en cada una de estas áreas durante la semana en la que se 
tomaron las observaciones (Figura 88). La distribución obtenida indica que la disponibilidad real no cumple con las expectativas de la mayoría de los estudiantes, que solo alquilarían un vehículo situado dentro del área de radio 500 metros, o incluso 300 metros. La gráfica muestra que un incremento de la disposición a caminar de los estudiantes hasta los 700 metros incrementaría la oferta de vehículos, especialmente en hora punta de los días laborables.
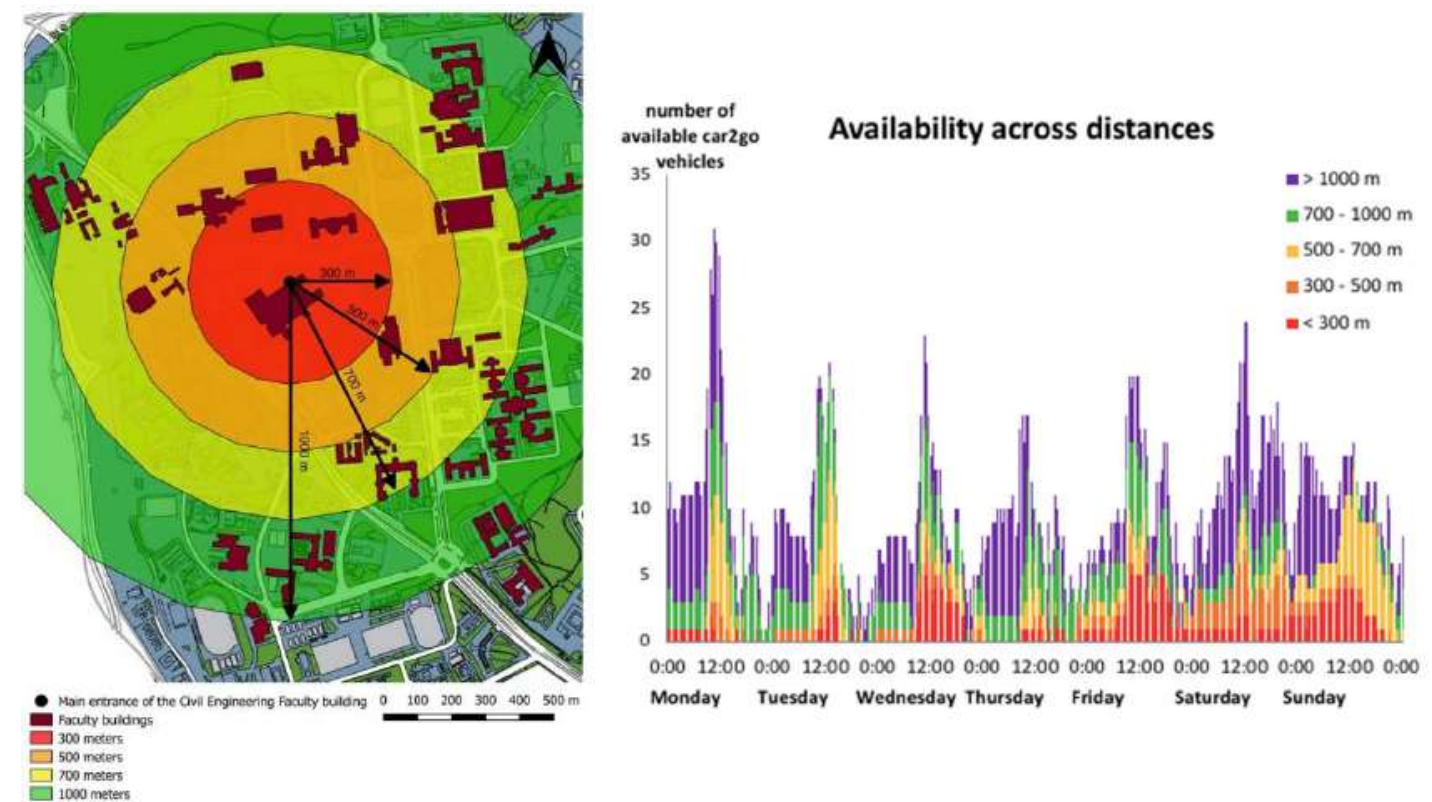

Figura 8. Vehículos de Car2go disponibles en función de la distancia a la que se encuentran de la puerta principal de la Escuela de Caminos, Canales y Puertos en el campus de Ciudad Universitaria.

Finalmente, se tomó la información de aquellos estudiantes que vivían en el interior del área de servicio del operador y se hicieron dos clusters teniendo en cuenta si habían usado o no el servicio (36 usuarios y 73 no usuarios). Utilizando la herramienta Google Maps, se determinaron los tiempos de viaje desde el vecindario de los estudiantes hasta el centro universitario, tanto en coche como en transporte público. Como la única información proporcionada por los encuestados acerca de su domicilio era el código postal, se consideró que los orígenes de los viajes eran los centros de gravedad de los polígonos de cada código postal. Para este análisis solo se seleccionaron aquellos códigos postales situados en el interior del área de servicio de Car2go, pues tenía sentido comparar los tiempos de viaje de aquellos viajes que era posible hacer en un vehículo de FFCS en ese momento.

En la Tabla 2 se indican los tiempos de viaje estimados, así como la media de las distancias máximas que caminarían los encuestados que viven en cada código postal, hayan usado o no el servicio de Car2go. Los resultados revelaron que, en general, el tiempo de viaje en FFCS es un $61 \%$ del tiempo a realizar el mismo viaje en transporte público. Es decir, los estudiantes que se dirigieran a la ETSICCP en un vehículo de FFCS tardarían, de media, un 39\% menos en comparación con lo que tardan en transporte público, en condiciones de tráfico fluido. A estos tiempos de viaje habría 


\section{ANÁLISIS DEL IMPACTO DE LOS SISTEMAS DE FREE-FLOATING CARSHARING EN ENTORNOS URBANOS UTILIZANDO DATOS WEB: APLICACIÓN A LA CIUDAD DE MADRID}

que añadir los tiempos que tarda el individuo en dirigirse andando de un punto a otro del viaje (p.ej., desde su domicilio hasta la estación de metro o marquesina de autobús) y los tiempos de espera. De acuerdo con las estimaciones proporcionadas por Google Maps, el tiempo medio caminando desde los centros de gravedad de cada código postal hasta las estaciones consideradas es de siete minutos y el tiempo medio de espera a un modo de transporte, generalmente metro, es de tres minutos, lo que incrementaría el tiempo en transporte público unos diez minutos. Por otro lado, el tiempo que tarda el usuario andando hasta el vehículo que reserva también debería ser sumado al tiempo de viaje en FFCS. En todos los casos, la distancia media admisible señalada por los usuarios no excede los 650 metros, lo que equivale a siete minutos andando.

Tabla 2. Comparación de los tiempos de viaje en transporte público y en vehículo FFCS desde los códigos postales situados en el área de servicio hasta la ETSICCP. Se muestra la proporción de usuarios y no usuarios y la media de sus distancias admisibles a caminar hasta un vehículo disponible.

\begin{tabular}{|c|c|c|c|c|c|c|c|}
\hline \multirow{2}{*}{$\begin{array}{l}\text { Código } \\
\text { Postal }\end{array}$} & \multicolumn{2}{|c|}{ Usuarios FFCS } & \multicolumn{2}{|c|}{ No usuarios FFCS } & \multicolumn{2}{|c|}{ Tiempo de viaje } & \multirow{2}{*}{$\begin{array}{c}\% \text { FFCS } \\
\text { respecto a } \\
\text { TP }\end{array}$} \\
\hline & $\%$ Usuarios & $\begin{array}{c}\text { Distancia } \\
\text { adm. media }\end{array}$ & $\begin{array}{c}\% \text { No } \\
\text { usuarios }\end{array}$ & $\begin{array}{c}\text { Distancia } \\
\text { adm. media }\end{array}$ & $\begin{array}{l}\text { Transporte } \\
\text { público }\end{array}$ & FFCS & \\
\hline 28002 & $6 \%$ & 400 & $3 \%$ & 400 & 24 & 15 & $63 \%$ \\
\hline 28003 & $17 \%$ & 400 & $15 \%$ & 332 & 11 & 5 & $45 \%$ \\
\hline 28004 & $3 \%$ & 150 & $3 \%$ & 150 & 23 & 14 & $61 \%$ \\
\hline 28005 & $3 \%$ & 400 & - & - & 31 & 1 & $35 \%$ \\
\hline 28006 & $3 \%$ & 150 & $1 \%$ & 650 & 15 & 12 & $80 \%$ \\
\hline 28007 & $6 \%$ & 400 & $4 \%$ & 483 & 23 & 20 & $87 \%$ \\
\hline 28008 & $11 \%$ & 400 & $7 \%$ & 200 & 10 & 6 & $60 \%$ \\
\hline 28009 & $3 \%$ & 400 & $4 \%$ & 317 & 24 & 19 & $79 \%$ \\
\hline 28010 & - & - & $3 \%$ & 525 & 20 & 8 & $40 \%$ \\
\hline 28012 & - & - & $1 \%$ & 150 & 23 & 18 & $78 \%$ \\
\hline 28013 & - & - & $1 \%$ & 400 & 16 & 11 & $69 \%$ \\
\hline 28014 & - & - & $1 \%$ & 400 & 31 & 14 & $45 \%$ \\
\hline 28015 & $8 \%$ & 317 & $26 \%$ & 372 & 11 & 7 & $64 \%$ \\
\hline 28016 & $6 \%$ & 525 & $3 \%$ & 400 & 21 & 16 & $76 \%$ \\
\hline 28020 & $8 \%$ & 400 & $4 \%$ & 317 & 19 & 12 & $63 \%$ \\
\hline 28028 & $6 \%$ & 400 & $7 \%$ & 350 & 20 & 16 & $80 \%$ \\
\hline 28029 & $6 \%$ & 400 & $3 \%$ & 400 & 33 & 9 & $27 \%$ \\
\hline 28030 & $3 \%$ & 650 & - & - & 34 & 22 & $65 \%$ \\
\hline 28035 & $3 \%$ & 150 & $1 \%$ & 650 & 16 & 7 & $44 \%$ \\
\hline 28036 & $3 \%$ & 150 & - & - & 22 & 16 & $73 \%$ \\
\hline 28039 & $3 \%$ & 400 & $5 \%$ & 338 & 14 & 9 & $64 \%$ \\
\hline 28040 & $3 \%$ & 150 & $4 \%$ & 400 & 10 & 4 & $40 \%$ \\
\hline 28045 & $3 \%$ & 400 & $1 \%$ & 150 & 31 & 18 & $58 \%$ \\
\hline 28046 & - & - & $1 \%$ & 400 & 20 & 12 & $60 \%$ \\
\hline Total & & & & & & & $61 \%$ \\
\hline
\end{tabular}




\section{V.2. ANÁLISIS DE LA DISTRIBUCIÓN ESPACIO-TEMPORAL DE LOS VIAJES Y PATRONES DE USO.}

Después de la fase preliminar, se procedió a la adquisición y almacenamiento de los datos publicados por los operadores de FFCS y a la correspondiente limpieza de la base de datos obtenida. Del análisis preliminar en un barrio de la ciudad con una metodología con limitaciones, se pasó a la adquisición de datos de vehículos FFCS en toda la ciudad de Madrid mediante una plataforma más compleja. La Figura 99 muestra la distribución tanto de las reservas (todos los registros en los que un usuario reservó un vehículo) como de los alquileres (reservas en las que se produjo un viaje) que se produjeron durante el periodo de tiempo seleccionado: desde el 28 de noviembre de 2017 hasta el 12 de abril de 2018. En esta investigación se entiende por "reserva" (bookings), aquel registro de la base de datos en el que se supone que un usuario reservó un vehículo, se produjera o no un viaje, y por "alquiler" (rentals), aquella reserva en la que se supone que sí se produjo un viaje, según las hipótesis consideradas en la limpieza de la base de datos. En el caso de Car2go, representado en azul, la línea punteada que representa las reservas coincide prácticamente con la línea de los alquileres, indicando que la cantidad de reservas sin viaje fue muy reducida. Sin embargo, las cifras de Emov, representado en rosa, indican que el número de reservas en las que no se produjo un viaje fue elevado. Esto se debe a una mala práctica de algunos usuarios de Emov que volvían a reservar el mismo coche cuando el tiempo de reserva de 20 minutos se agotaba, hasta que finalmente lo utilizaban tras varias reservas consecutivas o, incluso, no lo llegaban a utilizar nunca. A partir de febrero de 2018, la compañía limitó las reservas consecutivas debido a que generaba una reducción de la disponibilidad y esto, a su vez, una pérdida de ingresos. Por otro lado, en los datos adquiridos se detectó un número elevado de supuestas reservas canceladas en los minutos iniciales, pero se llegó a la conclusión de que eran vehículos que se desconectaban momentáneamente (en torno a 1 ó 2 minutos) del sistema y la plataforma de adquisición interpretaba la indisponibilidad como un registro.

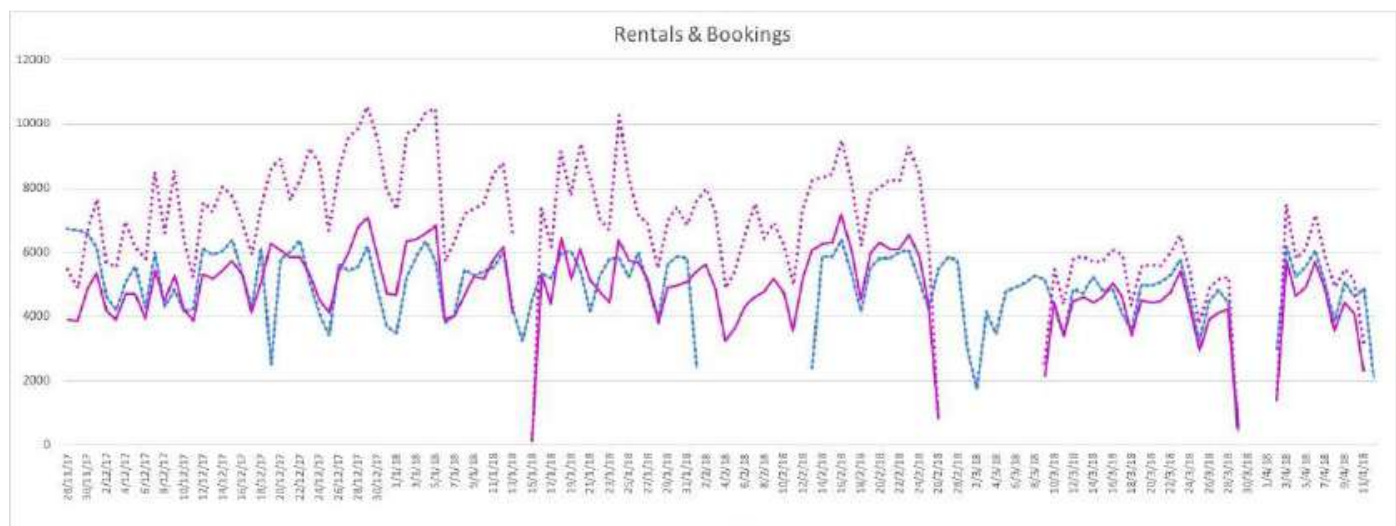

Figura 9. Reservas y alquileres diarios de Car2go y Emov durante el periodo de estudio. 


\section{ANÁLISIS DEL IMPACTO DE LOS SISTEMAS DE FREE-FLOATING CARSHARING EN ENTORNOS URBANOS UTILIZANDO DATOS WEB: APLICACIÓN A LA CIUDAD DE MADRID}

Una vez se limpió la base de datos de las anomalías detectadas y se extrajeron aquellos periodos con un comportamiento particular (p.ej., días festivos o periodos vacacionales, a partir del calendario oficial de la ciudad), se obtuvieron los perfiles medios diarios de los alquileres por día de la semana (Figura 1010), los cuales resultaron similares para ambos operadores. En días laborables (Figura 1010 (a) y (b)) se producen tres máximos, peculiaridad de la capital española que ya habían señalado Habibi et al. (2017), frente a otras ciudades en las que solamente se producen dos. El primer pico se produce en la hora punta de la mañana cuando se generan la mayoría de los viajes de commuters (7:00-9:59 h). Se alarga en el tiempo en comparación con la hora punta del vehículo privado, como ya se vio en el análisis llevado a cabo en la fase preliminar: el usuario tiende a evitar los periodos de máxima congestión debido a la tarificación del sistema. El segundo periodo de máximos en el día es el que es exclusivo de Madrid y se produce alrededor de la hora de comer (13:00-15:59 h), probablemente por el hecho de tener una jornada laboral más extensa. El tercer pico se produce en la hora punta de la tarde (18:00-20:59 h) cuando los ciudadanos vuelven a casa o se dirigen a realizar actividades de ocio. Los fines de semana (Figura 10 (c) y (d)) solo se producen dos periodos de máximos: en torno a las $13 \mathrm{~h}$ y a las 20 h. Por lo general, el máximo semanal se produce los viernes entre las 14 y $15 \mathrm{~h}$, cuando tienen lugar, de media, 400 viajes.

Se observó una cantidad ligeramente mayor de viajes en Car2go durante el periodo de estudio, pese a tener una flota más reducida (500 vehículos frente a los 600 de Emov). Cuando la adquisición de datos tuvo lugar, la tarifa del primero era de $0.21 € /$ minuto mientras que el segundo cobraba $0.24 € /$ minuto. Los datos indican que Car2go se usó más para viajes de commuting en día laborable en los que, generalmente, el usuario viaja solo y, por tanto, tiene sentido pagar una tarifa menor por un vehículo biplaza, mientras que Emov se utilizó más para viajes de ocio en fin de semana que tienden a compartirse con familiares y amigos y, por tanto, requieren de un vehículo con mayor capacidad. 


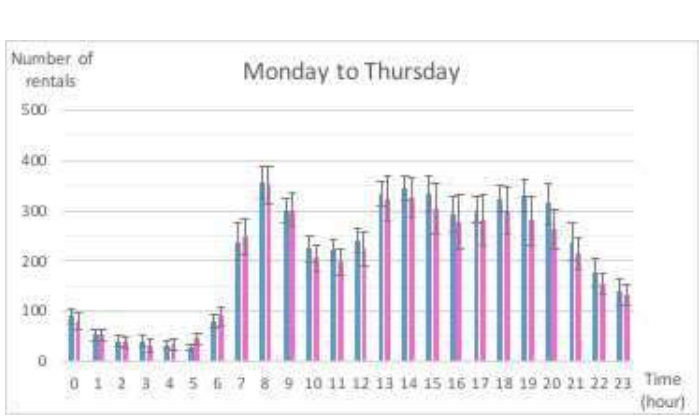

(a)

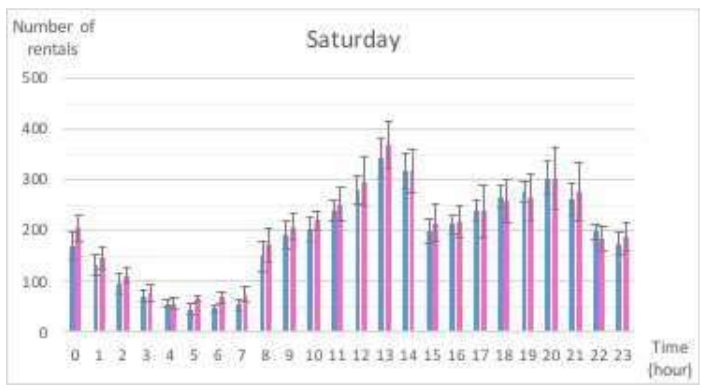

(c)

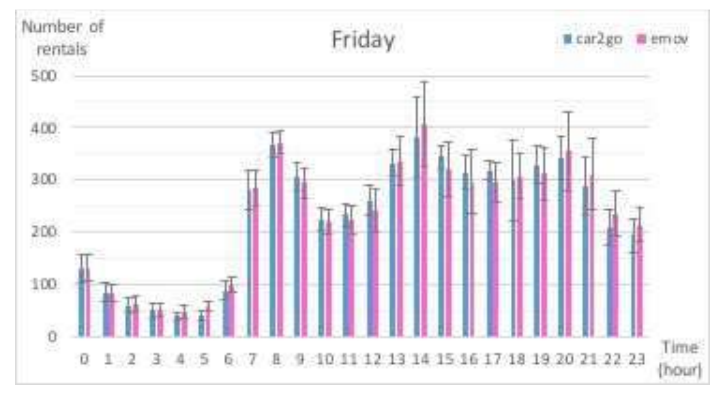

(b)

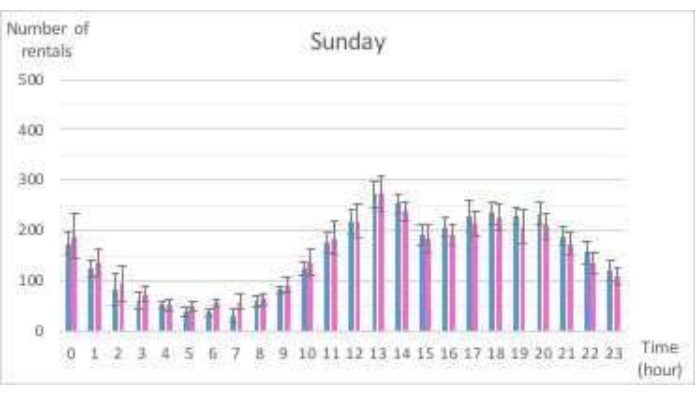

(d)

Figura 10. Promedio de viajes por día de la semana y por operador: (a) lunes a jueves, (b) viernes, (c) sábado y (d) domingo.

Para analizar la rentabilidad de los sistemas FFCS, es importante tener en cuenta cómo se comportan sus usuarios. Como las tarifas varían en función de la duración del viaje, para que un sistema sea rentable, cada coche debe utilizarse el máximo tiempo posible y esto implica que se realicen varios viajes al día cuya duración sea lo más alta posible. Según las cifras expuestas por Habibi et al. (2017) y la información suministrada por los operadores locales, un coche FFCS realizaba en torno a diez viajes diarios en Madrid cuando había dos operadores, volumen de viajes muy superior a otros lugares donde estos sistemas llevaban más tiempo funcionando (Kortum et al., 2016).

En cuanto a la duración de cada viaje, en esta investigación se analizó la distribución de los alquileres que se produjeron en el periodo de tiempo seleccionado (Figura 11 (a)). Se trata de una distribución asimétrica hacia la derecha, cuya moda es 22 minutos y la mediana en torno a 27 minutos. Un $20 \%$ de los alquileres duró menos o igual a 18 minutos, mientras que otro $20 \%$, más de 47 minutos. Se debe tener en cuenta que el tiempo representado no solo incluye el tiempo de viaje sino también el tiempo de la reserva previa, puesto que es el total de tiempo en el cual el coche no está disponible. Aunque el tiempo máximo de reserva permitido ( $\sin$ considerar reservas consecutivas) son 20 minutos, el tiempo medio de reserva, según las estimaciones de los operadores, se sitúa en 8 minutos.

La distribución de los tiempos de los alquileres de ambos operadores es similar. Sin embargo, al observar el porcentaje acumulado, las líneas se distancian de forma notable, siendo el de Car2go superior. Más de un 15\% de los alquileres de vehículos de Emov duraron más de 120 minutos, mientras que en el caso de Car2go apenas fue 


\section{ANÁLISIS DEL IMPACTO DE LOS SISTEMAS DE FREE-FLOATING CARSHARING EN ENTORNOS URBANOS UTILIZANDO DATOS WEB: APLICACIÓN A LA CIUDAD DE MADRID}

un $6 \%$. La diferencia puede deberse a la económica tarifa por día que ofrecía Emov, en la que el coste no ascendía a partir de la quinta hora de alquiler.

Además, se analizó la duración de las reservas en las que supuestamente no se produjo un viaje (Figura 11 (b)), porque el inicio y fin de las mismas se situó en el mismo emplazamiento y no hubo consumo de batería. Ambas curvas convergen hacia el tiempo máximo de reserva que es 20 minutos, a partir del cual la reserva se cancela automáticamente si el viaje no ha empezado. Sin embargo, en el caso de las reservas consecutivas, el usuario podría cancelar y, acto seguido, volver a reservar, sin que la plataforma de adquisición hubiera detectado que el coche había estado disponible por un instante. Por este motivo, las curvas se prolongan, no alcanzando el $100 \%$ a los 20 minutos.

En el caso de Emov, el $80 \%$ de las resenas sin viaje fueron canceladas en los primeros dos minutos. Como se ha explicado previamente, esto se debe a fallos en la conectividad de los vehículos y no a que se hubieran realizado reservas reales. Después, la tasa de cancelación asciende de forma constante hasta los 20 minutos. No obstante, la cancelación automática que se produce al agotarse el tiempo máximo de reserva, tiene lugar en ambos operadores con un desfase de un minuto, probablemente por las diferencias ocasionadas por el tiempo de muestreo de 30 segundos. El porcentaje acumulado de la duración de las reservas sin viaje de Car2go crece asintóticamente hasta alcanzar un $95 \%$ en el tiempo máximo de reserva. 


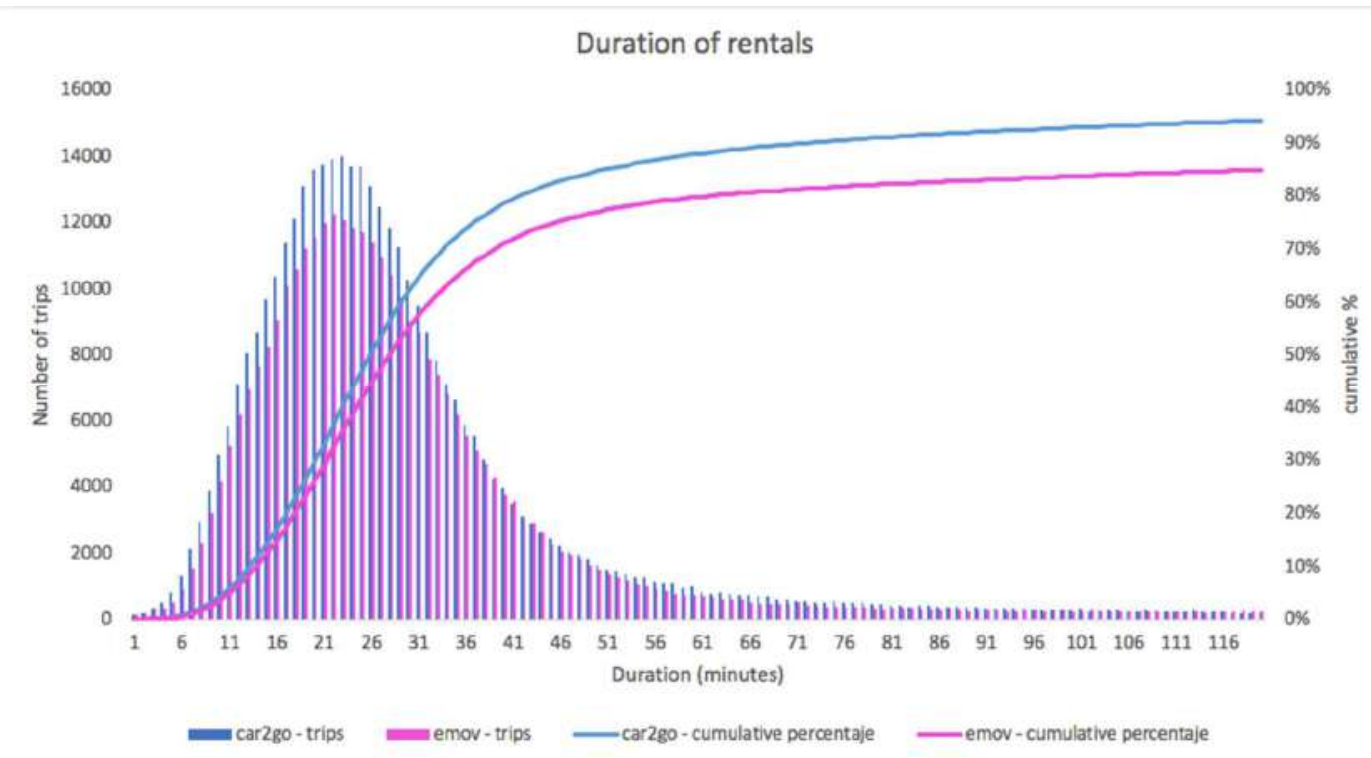

(a)

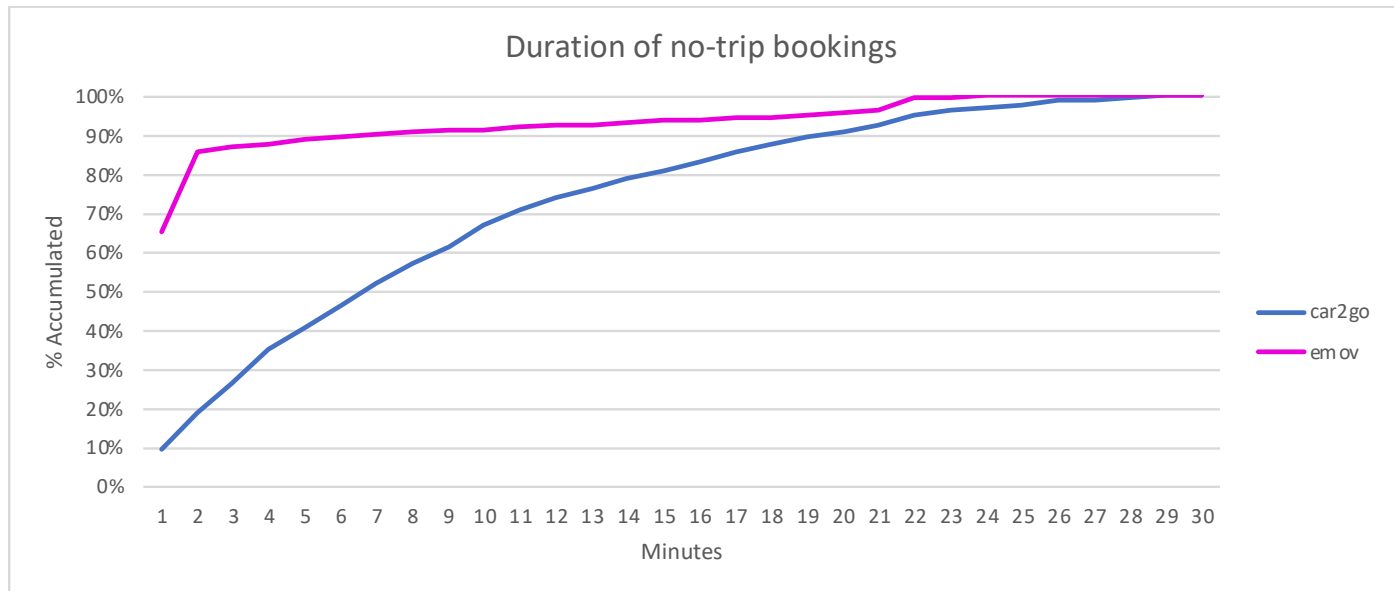

(b)

Figura 11. (a) Duración en minutos de los alquileres (reservas en las que sí se produjo un viaje). (b) Duración en minutos de las reservas en las que no se produjo un viaje.

Con respecto a la distribución espacial, se hizo un análisis con el objetivo de identificar aquellas zonas con mayor frecuencia de generación y/o atracción de viajes. Para ello, se tomó como unidad espacial la delimitación en barrios administrativos. El municipio de Madrid se divide en 21 distritos que a su vez se dividen en barrios. Dentro de las áreas de servicio de los operadores de FFCS hay aproximadamente 50 barrios, la mayoría de ellos pertenecientes a los siete distritos de la Almendra Central.

Tomando el total de viajes efectuados en el periodo de tiempo analizado, se determinó la frecuencia de que cada barrio fuera origen o destino. En la Figura 12 (a) se representan los barrios en función de su frecuencia como generadores de viajes, siendo verde oscuro la mayor frecuencia y blanco, la menor. De forma similar, en la Figura 12 (b) se representan los destinos, siendo aquellos barrios con un rojo más oscuro, aquellos que más viajes atrajeron. Los barrios colindantes con el Paseo de la Castellana tienden a ser zonas generadoras y atractoras de viajes, mientras que se 


\section{ANÁLISIS DEL IMPACTO DE LOS SISTEMAS DE FREE-FLOATING CARSHARING EN ENTORNOS URBANOS UTILIZANDO DATOS WEB: APLICACIÓN A LA CIUDAD DE MADRID}

producen muy pocos viajes desde o hacia el Distrito Centro debido a las dificultades de aparcamiento frente a la elevada oferta de transporte público. Es posible que, tras la implementación de la Zona de Bajas Emisiones Madrid Central unos meses después de la adquisición de datos, los viajes que tienen como origen o destino el Distrito Centro hayan aumentado. Esta regulación restringe el acceso de vehículos de combustión interna a la zona, pero permite la circulación y aparcamiento de vehículos eléctricos (ambos operadores tienen flotas eléctricas), por lo que podrán hacer uso de una mayor oferta de aparcamiento disponible.

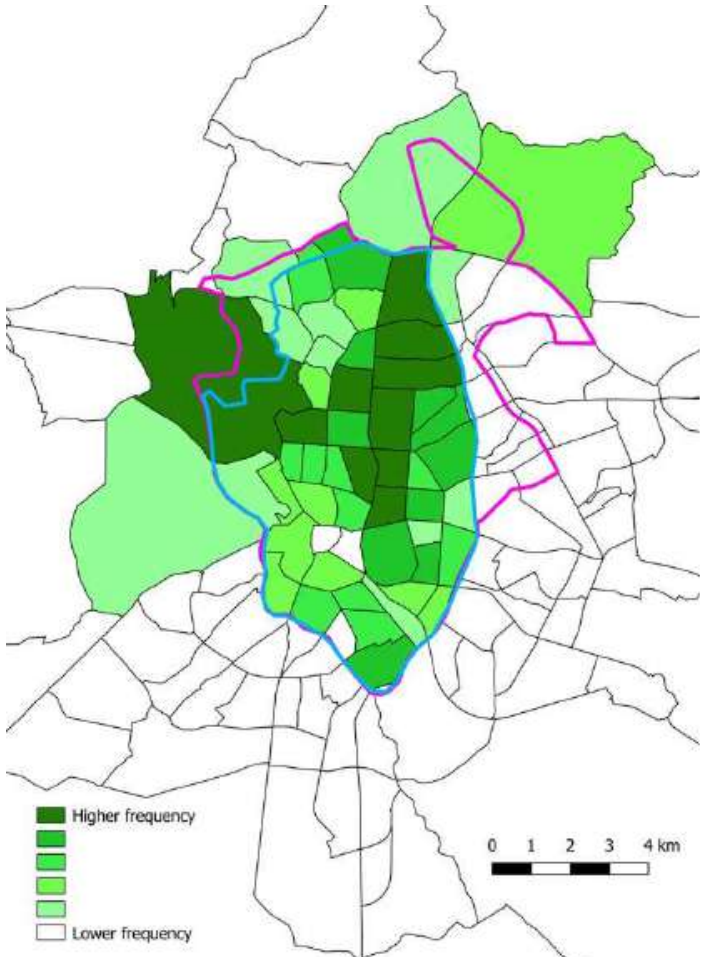

(a)

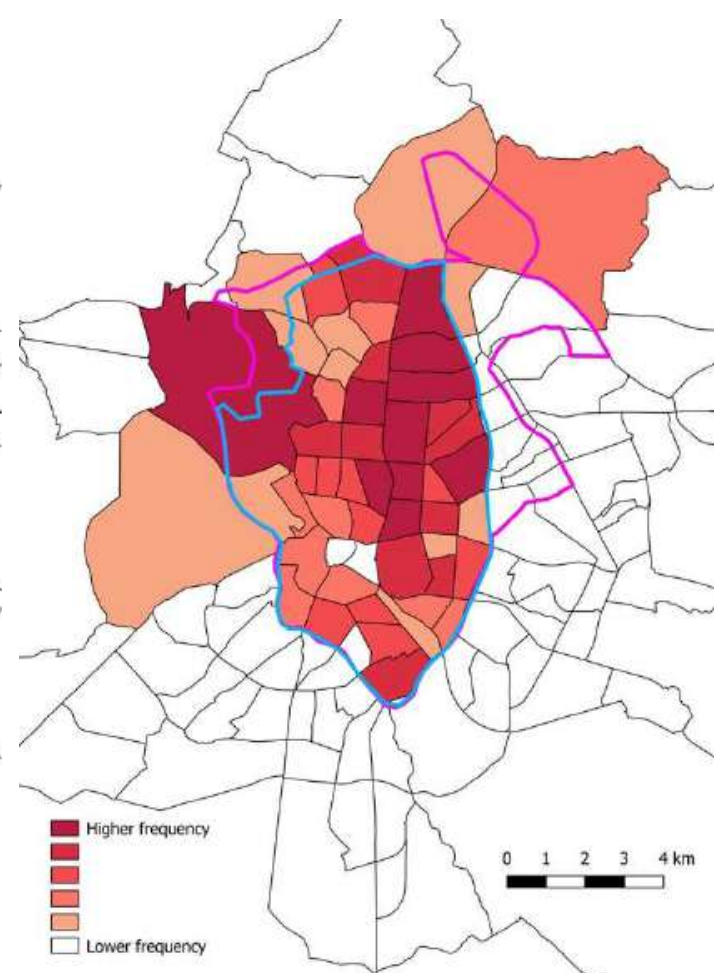

(b)

Figura 12. Frecuencia de los orígenes (a) y destinos (b) de los viajes FFCS analizados.

Se profundizó en el análisis temporal, analizando los pares Origen-Destino en periodos concretos, especialmente en las horas punta. Las figuras 13 y 14 representan los 20 pares O-D más frecuentes en los periodos de tiempo seleccionado. Cada flujo se representa con una línea con color degradado que va desde el centroide del barrio origen, en verde, al centroide del barrio destino, en rojo. Cuando el flujo es bidireccional, la línea se representa con un color de gradiente rojo-verde-rojo. Aquellos viajes que tienen origen y destino en el mismo barrio se muestran con un punto rojo.

Se escogieron los viajes iniciados en tres periodos de tiempo de tres horas cada uno de ellos, coincidiendo con los periodos punta según el análisis del perfil de viaje en día laborable (Figura 10): 7:00-9:59 h, 13:00-15:59 h y 18:00-20:59 h. El primero corresponde con la hora punta de la mañana, que en el caso de los sistemas FFCS se extiende hasta más tarde; el segundo engloba los viajes realizados en la hora de comer; y el tercero coincide con la hora punta de la tarde. Teniendo en cuenta el 
motivo de los viajes, se decidió agrupar la representación de flujos del primer y segundo periodo con los viajes generados de lunes a viernes; y del tercero, con los producidos de lunes a jueves, analizando el viernes por separado. Por lo general, la jornada laboral de lunes a jueves acaba en torno a las $18 \circ 19 \mathrm{~h}$, mientras que los viernes suele terminar a las 14 o $15 \mathrm{~h}$, por lo que en el periodo de 18:00 a 20:59 h de los viernes, se entiende que habrá mayor proporción de viajes de ocio.

La Figura 133 (a) representa los 20 pares más frecuentes en el periodo punta de la mañana en día laborable, cuando se generan viajes desde las zonas residenciales a las zonas empresariales. Se observa gran cantidad de movimientos a lo largo de la Castellana y que los flujos más frecuentes cubren distancias mayores que en los otros periodos analizados. En la Figura 13 (b) se representan los flujos más frecuentes en el periodo de 13:00 a 15:59 h en día laborable. Algunos de los pares del periodo de la mañana se repiten en sentido contrario, indicando la vuelta a casa de algunos usuarios. Se incrementan los viajes de ida y vuelta a un mismo barrio (round trip), lo que podría indicar que el periodo de tiempo para comer se utiliza para hacer recados y volver al punto de origen del viaje.

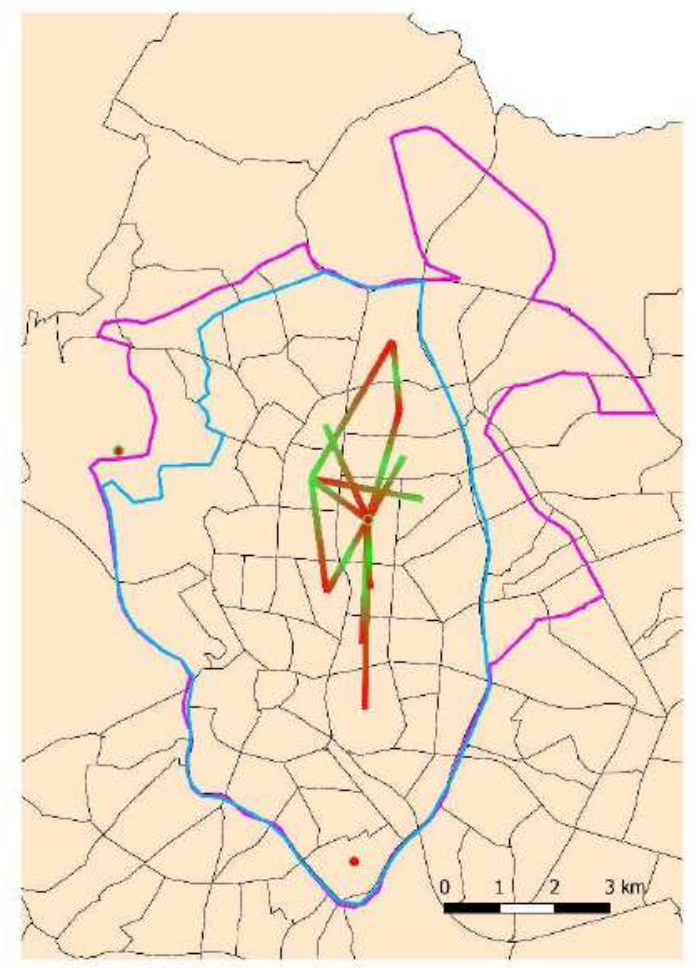

(a)

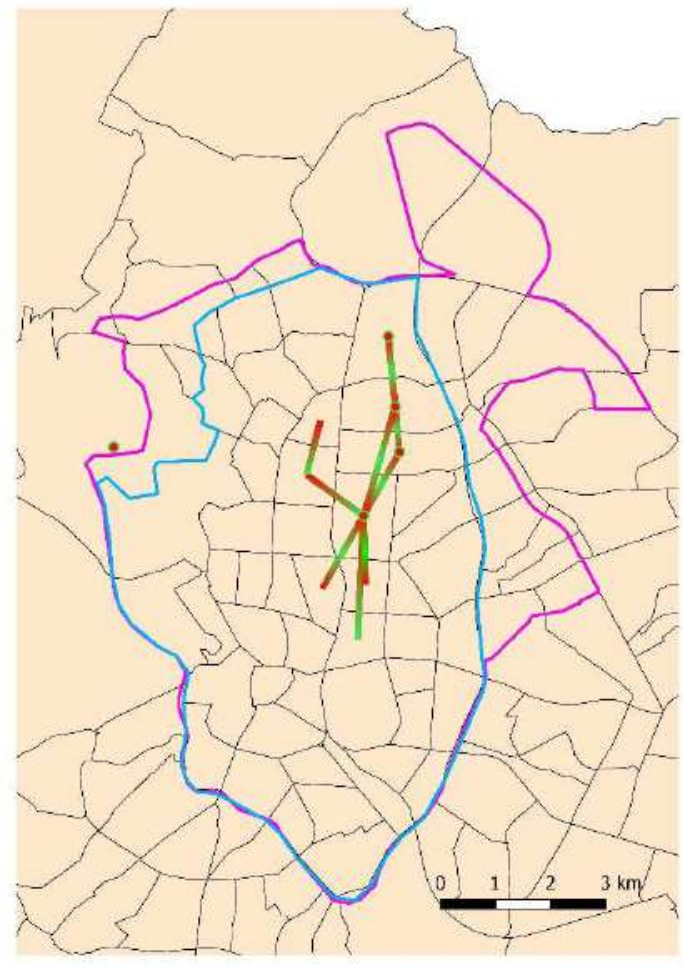

(b)

Figura 13. Flujos O-D más frecuentes: (a) de lunes a viernes de 7:00 a 9:59 h y (b) de lunes a viernes de 13:00 a 15:59 h. 


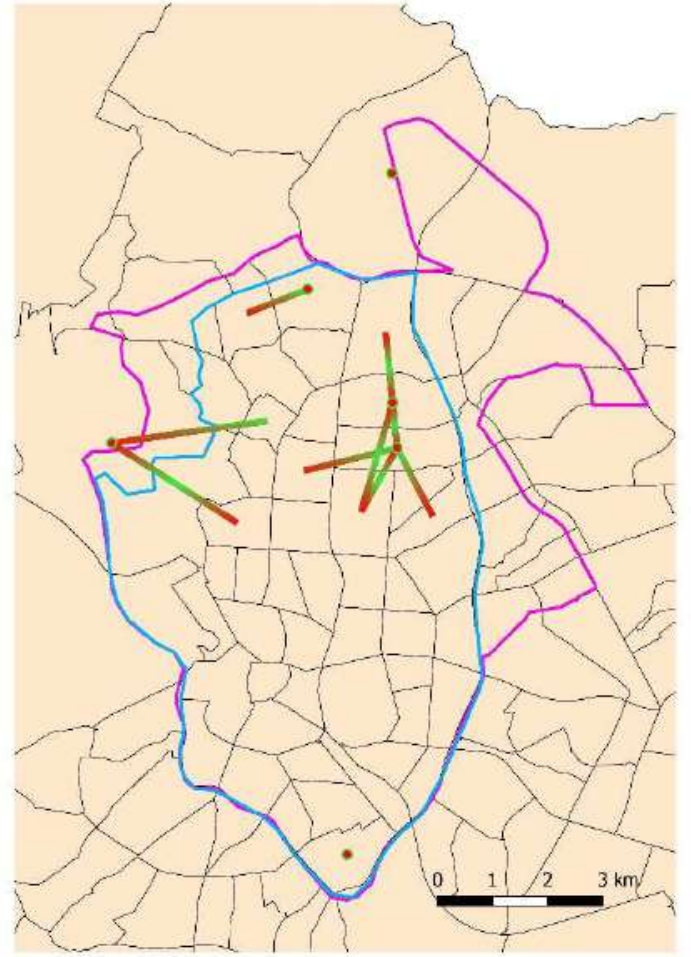

(a)

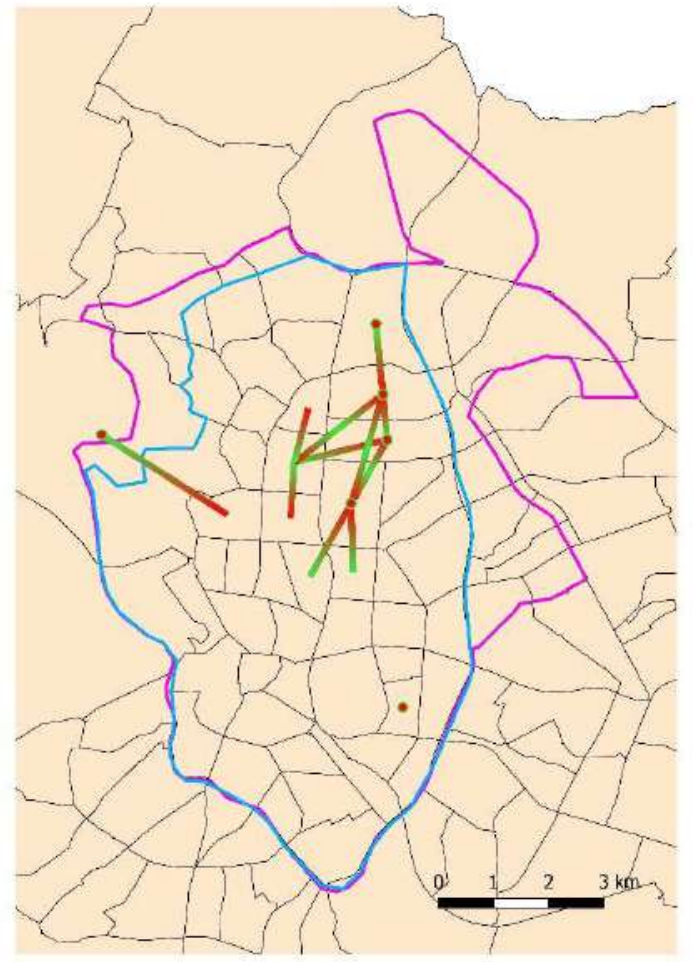

(c)

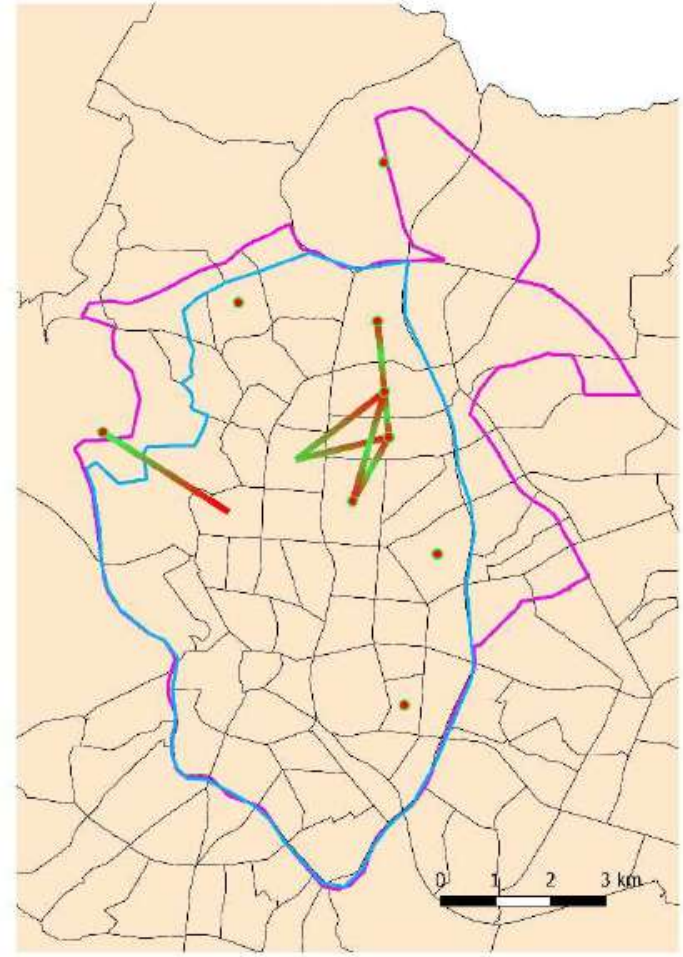

(b)

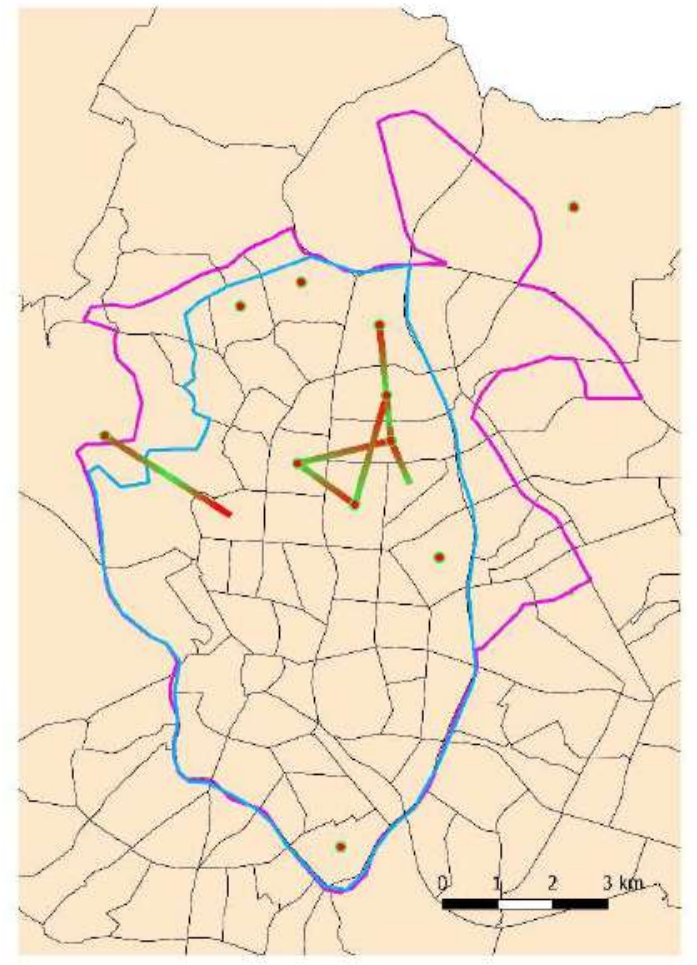

(d)

Figura 14. Flujos O-D más frecuentes en la franja horaria de 18:00 a 20:59 h: (a) de lunes a jueves, (b) viernes, (c) sábado y (d) domingo.

La Figura 14 representa los viajes más frecuentes de 18:00 a 20:59 h: de lunes a jueves (a), los viernes (b), los sábados (c) y los domingos (d). Destacan entre los más 
frecuentes, los viajes desde y hacia el campus de Ciudad Universitaria, en el oeste, especialmente de lunes a jueves. Otra diferencia respecto a las franjas analizadas previamente es que los fines de semana por la tarde se generan más viajes que tienen como destinos barrios más alejados o viajes round-trip en estas zonas. Aunque el total de viajes producido en esta franja horaria es similar a los otros periodos punta, a excepción del domingo, los barrios más frecuentes generan o traen menos viajes, haciendo que el abanico de pares O-D sea más extenso.

\section{V.3. ANÁLISIS DEL IMPACTO EN EL TRANSPORTE PÚBLICO}

De forma similar al análisis realizado en la etapa preliminar, se utilizó la herramienta Google Maps para comparar viajes en vehículo de FFCS con viajes realizados en transporte público. En este caso, las coordenadas de origen y destino correspondían a la información adquirida de los viajes reales de los operadores y la variabilidad de pares OD fue muy superior, cubriendo todo el área de los operadores, pues anteriormente solo se habían reproducido viajes desde los barrios de residencia de los estudiantes hacia el campus universitario.

A diferencia del análisis previo, en el cálculo de los tiempos de viaje en transporte público se incluyó el tiempo que una persona tarda en recorrer andando la distancia desde el punto de origen hasta la estación o marquesina en la que se inicia el trayecto en transporte público y desde la estación final hasta el punto final registrado, así como el tiempo medio de espera de acuerdo a las líneas seleccionadas en la ruta óptima. El tiempo de viaje en FFCS se estimó a partir del tiempo que se tarda en recorrer en coche la ruta óptima desde las coordenadas de inicio hasta las coordenadas de fin de viaje, sin tener en cuenta el tiempo de reserva previo al inicio del viaje, que sí se incluye en los registros de la base de datos. No obstante, también se debía considerar el tiempo que tarda el usuario andando hasta el coche, pero se desconocía el origen real de los viajes. De acuerdo con los resultados revelados en la encuesta de la fase preliminar, los usuarios generalmente están dispuestos a caminar una distancia entre 300 y 500 metros hasta un vehículo disponible, por lo que se añadió al tiempo de viaje un tiempo adicional de 5 minutos que equivaldría a recorrer dicha distancia andando. El tiempo que se tarda desde la posición final del vehículo hasta el destino real del viaje se despreció, puesto que se supone que el coche se aparcará lo más cerca posible del destino final del viaje.

En la Figura 15 (a) se comparan los tiempos medios de viaje siguiendo las rutas óptimas propuestas por Google Maps de los 60 pares O-D más frecuentes (excluyendo los round-trip o con origen y destino en el mismo barrio) durante el periodo punta de la mañana en día laborable. Los viajes con origen y destino en los mismos barrios se han agrupado para simplificar la representación, mostrando el tiempo medio. A medida que dos barrios están más cerca, el tiempo de viaje adicional en transporte público es menor, aunque proporcionalmente representan un mayor 


\section{ANÁLISIS DEL IMPACTO DE LOS SISTEMAS DE FREE-FLOATING CARSHARING EN ENTORNOS URBANOS UTILIZANDO DATOS WEB: APLICACIÓN A LA CIUDAD DE MADRID}

incremento si lo comparamos con el mismo viaje en coche. Viajes de distancia reducida en FFCS pueden suponer un $100 \%$ de tiempo adicional si se realizan en transporte público. Esto puede explicar que se produzcan gran cantidad de viajes entre barrios cercanos, ya que la alternativa en transporte público duplica el tiempo de viaje.

También se analizó el coste económico que tiene para el usuario según la duración del viaje simulado mediante Google Maps (Figura 15 (b)). Según la muestra analizada, el coste para el usuario de FFCS es, de media, prácticamente el doble a realizar el viaje en transporte público, aunque en algunos casos puede llegar a triplicarse. Se consideraron tarifas por minuto que tenían los operadores en el momento de la adquisición de datos (Car2go: 0,21 €/min; Emov: 0,24 €/min). No obstante, en la actualidad estas tarifas han aumentado, lo que significaría que el incremento sería aún mayor. Con respecto al coste del viaje en transporte público, se consideró la tarifa del billete sencillo, que oscila entre 1,5 y $2 €$, en función del recorrido del viaje y del número de estaciones por las que pasa. Si el viajero tiene abono de transporte, ya sea normal o con descuento, o utiliza billetes combinados de varios viajes, el importe por viaje sería inferior, haciendo que la diferencia de costes sea más notable.

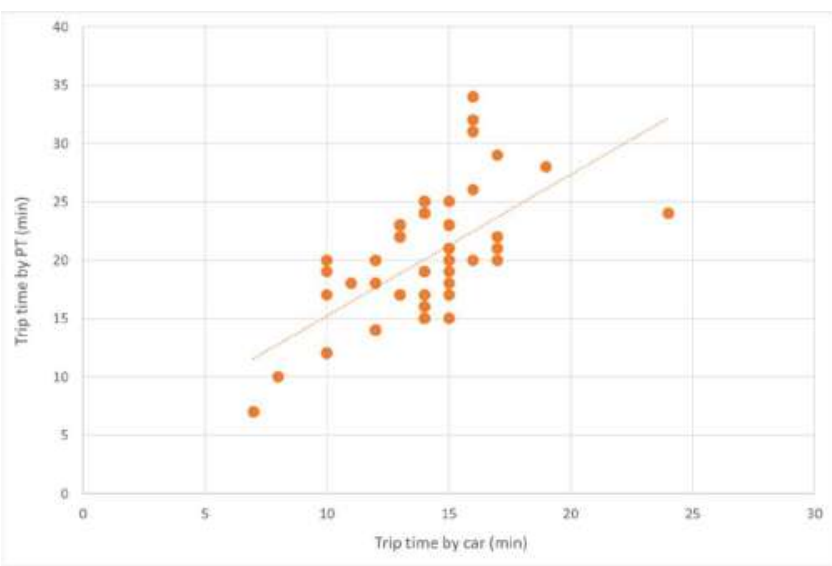

(a)

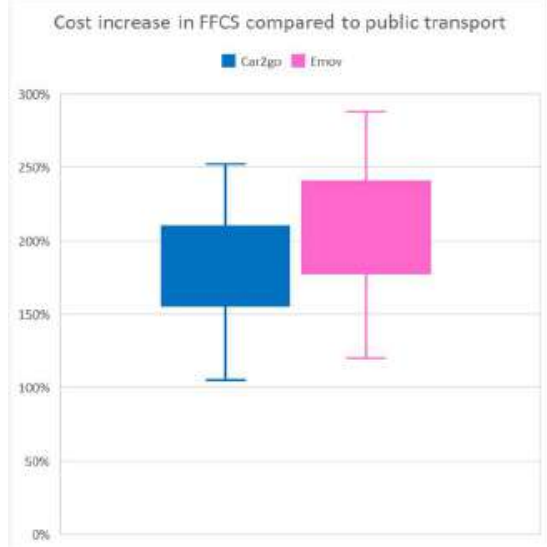

(b)

Figura 15. (a) Comparación de tiempos de viaje en coche de FFCS y en transporte público de los pares O$D$ más frecuentes durante el periodo punta de la mañana. (b) Incremento de tiempo de viaje en transporte público comparado con el tiempo de viaje en FFCS durante el periodo punta de la mañana. (c) Incremento de coste de viaje en FFCS respecto al coste del viaje en transporte público.

\section{V.4. ANÁLISIS POR BARRIO}

El tercer artículo se enfocó hacia el análisis espacial de los viajes identificados con el objetivo de evaluar las características de zonas concretas de la ciudad que generaran o atrajeran un volumen importante de viajes. Como ya se había hecho previamente, se tomó la delimitación administrativa en barrios, considerando que esta unidad espacial es lo más homogénea posible, al mismo tiempo que tiene un tamaño considerable para no desagregar la ciudad en exceso. Partiendo del número total de viajes que se originaron en cada barrio a lo largo de todo el periodo de tiempo analizado (Figura 16), se analizaron las características de los que tuvieron una mayor frecuencia de viajes. 


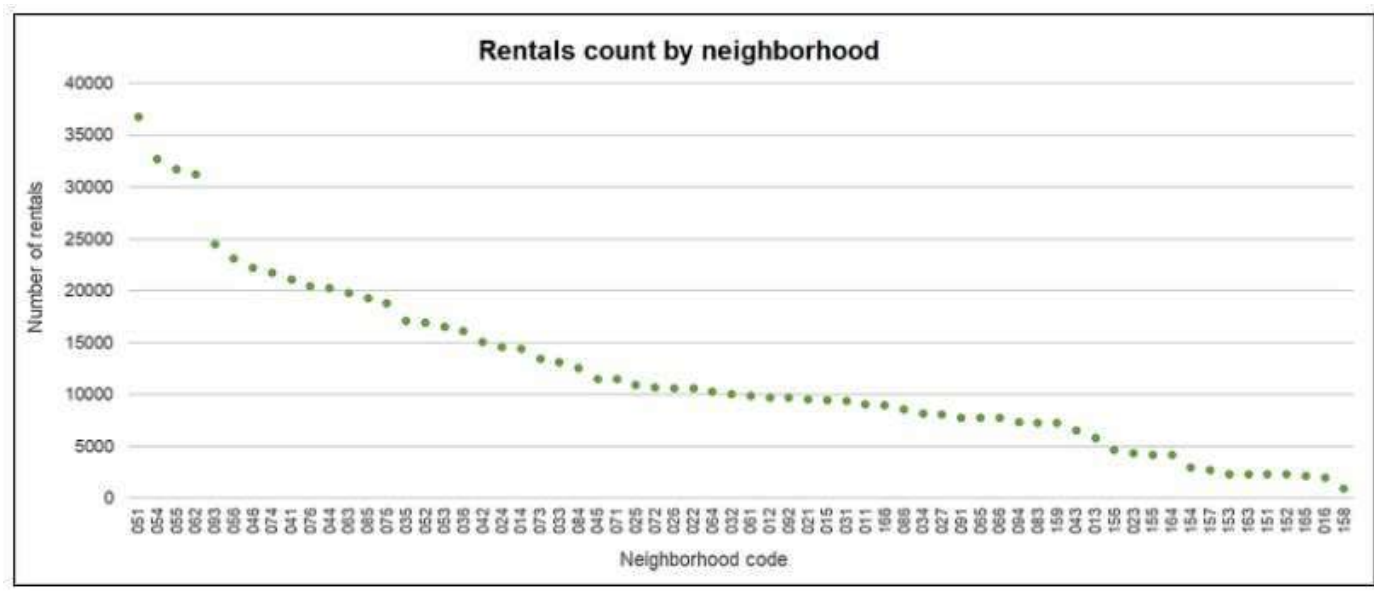

Figura 16. Alquileres producidos en cada barrio en el periodo de tiempo estudiado (los códigos de los barrios se indican en la figura 3 ).

Se decidió extraer de este análisis los viajes con origen y destino en el mismo barrio, debido a las dificultades para deducir su trayectoria y motivo de viaje. Como los datos adquiridos carecen de un registro de la trayectoria recorrida, desconocemos la proporción de viajes que tuvieron lugar dentro de un barrio frente a aquellos en los que el usuario se dirigió de un punto a otro de la ciudad y volvió al barrio de origen en el mismo viaje. Es cierto que en los viajes de corta duración hay mayor proporción de viajes que tienen el mismo barrio de origen y destino (Figura 17), lo que podría indicar que se estuvieran produciendo viajes "internos" dentro del barrio. No obstante, se decidió no considerar este grupo y profundizar en el análisis de los viajes que tuvieron lugar entre barrios diferentes, siendo estos un $87,3 \%$ de los viajes con duración inferior o igual a 15 minutos y un $96,1 \%$ de los viajes que duran más de 15 minutos (hay que recordar que la duración indicada incluye el tiempo de reserva).

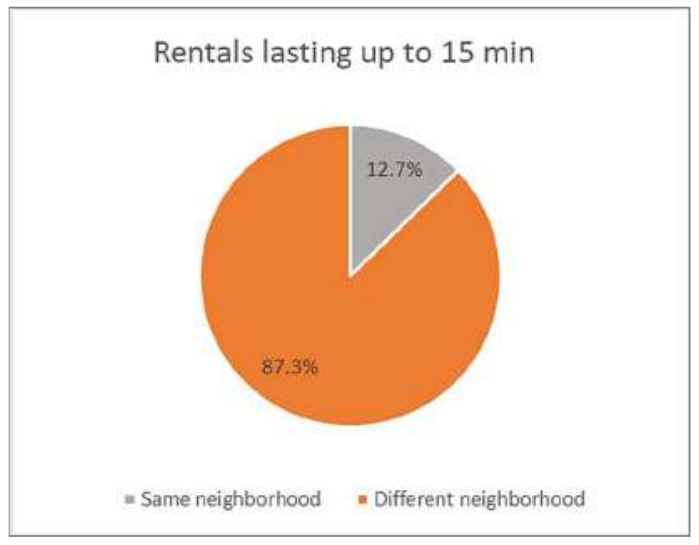

(a)

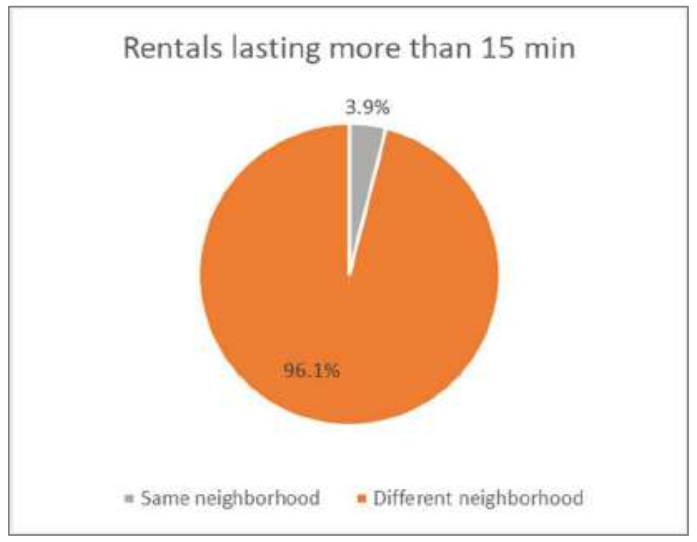

(b)

Figura 17. Proporción de viajes con origen y destino en el mismo barrio frente a viajes con origen $y$ destino en en distintos barrios en (a) viajes que duran hasta 15 minutos y (b) viajes que duran más de 15 minutos.

Teniendo en cuenta las diferencias entre viajes de FFCS en función de su duración, fueron desagregados en tres grupos con el objetivo de analizar sus peculiaridades, 


\section{ANÁLISIS DEL IMPACTO DE LOS SISTEMAS DE FREE-FLOATING CARSHARING EN ENTORNOS URBANOS UTILIZANDO DATOS WEB: APLICACIÓN A LA CIUDAD DE MADRID}

como ya habían hecho otros autores (Habibi et al., 2017; Sprei et al., 2019). En la Figura 18 se representan las distribuciones de los pares origen-destino más frecuentes de cada uno de los grupos: viajes con duración inferior o igual a 15 minutos, entre 16 y 30 minutos y superior a 30 minutos. Se señalan los periodos de mayor demanda a lo largo de un día laborable de acuerdo con el análisis llevado a cabo previamente (Figura 10).

El primer grupo, formado por prácticamente un $20 \%$ de los viajes analizados, comprende aquellos registros que duraron hasta 15 minutos, incluyendo el tiempo de reserva y el tiempo real de viaje. Como ya se ha explicado, aunque el tiempo máximo de reserva en ambos operadores analizados sea de 20 minutos, de media, una reserva dura alrededor de 8 minutos. Esto supone que el tiempo de viaje real en este grupo sea reducido. El análisis de los pares OD muestra que estos viajes se realizaron entre barrios muy cercanos y que la frecuencia de repetición de los más frecuentes es relativamente alta (en torno a $0,9 \%$ ).

Más del $40 \%$ de los registros tuvieron una duración de entre 15 y 30 minutos. Este grupo representa el comportamiento más probable, puesto que comprende tanto la mediana como la moda. Como se ha expuesto anteriormente, la mediana del total de viajes válidos se sitúa en 27 minutos y la moda es de 22 minutos. La dispersión de los pares OD es mayor que en el primer grupo, como indica la menor frecuencia de aquellos mostrados en el gráfico (el máximo es $0,46 \%$ ).

Por último, el tercer grupo se formó con los registros de duración superior a 30 minutos. Aunque el gráfico sólo muestra una duración entre 30 y 120 minutos, como se ha indicado, hay viajes que superaron la barrera de las 2 horas de duración (15\% de los viajes de Emov y $6 \%$ de los de Car2go). La dispersión de estos viajes no solo lo es en lo relativo a la duración, sino también en la variedad de orígenes y destinos posibles (frecuencia máxima de 0,19\%). Entre los más frecuentes, podemos encontrar pares entre barrios más alejados que en los grupos anteriores.

En cuanto a la división de los gráficos de los pares OD más frecuentes en periodos de tiempo, de media, prácticamente el $50 \%$ de los viajes ocurrieron en los tres periodos punta analizados, proporción que se cumple en los tres grupos. Cada periodo dura tres horas al día, de lunes a viernes, así que se podría decir que la mitad de los viajes entre los pares OD más frecuentes tuvieron lugar en un $27 \%$ del tiempo total de la semana. 

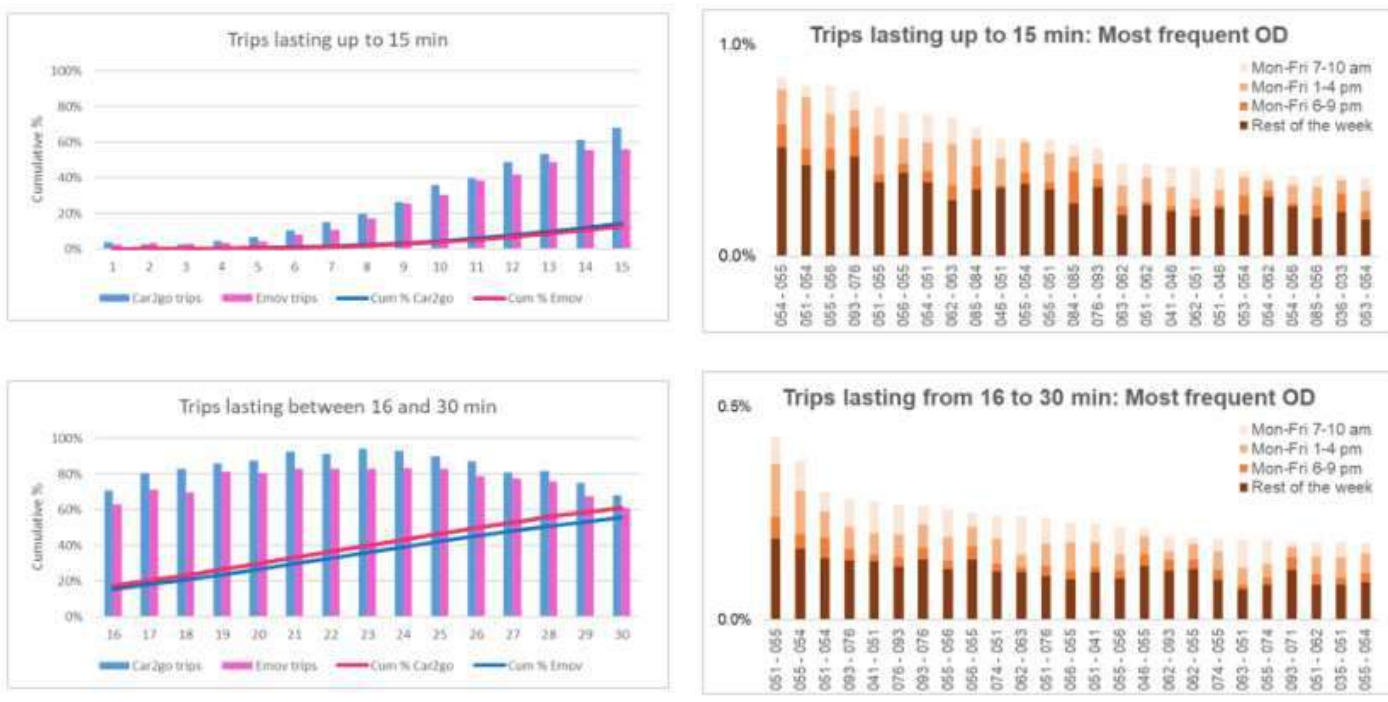

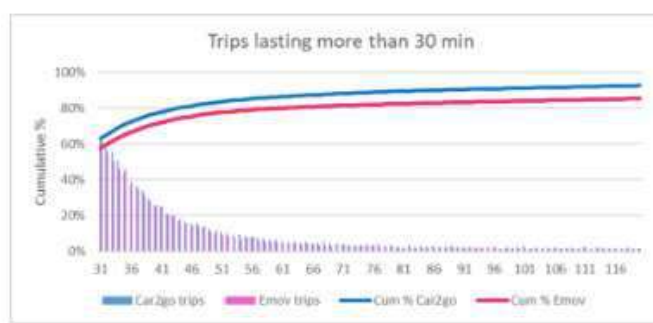

(a)

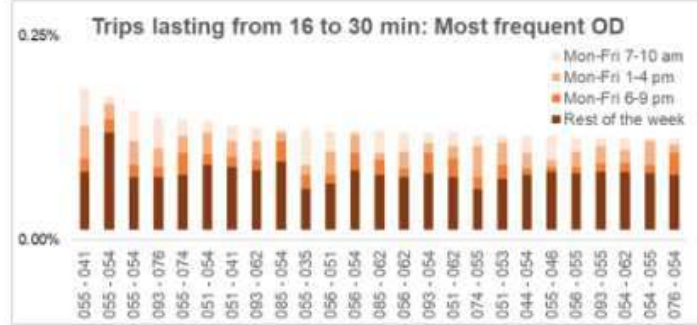

(b)

Figura 18. (a) Frecuencias de viajes y (b) pares Origen-Destino mas frecuentes en función de la duración del viaje (se han excluido los viajes con origen y destino en el mismo barrio).

De los barrios que se encuentran entre los orígenes y destinos más frecuentes se seleccionaron tres con el objetivo de llevar a cabo un análisis más detallado: EI Viso, Ciudad Universitaria y Cuatro Caminos, que corresponden a los códigos 051, 093 y 062, respectivamente, de la 3. A continuación, se detallan las peculiaridades que podrían hacer que estos barrios generaran o atrajeran un número elevado de viajes. En la Figura 19 se muestran las distribuciones horarias en día laborable de los viajes generados en estos barrios, así como las ubicaciones espaciales de los vehículos cuando se iniciaron viajes a lo largo del periodo de estudio. Además, se comparan los principales indicadores socioeconómicos de los tres barrios con la media de los distritos ubicados dentro de la Almendra Central y la media de toda la ciudad (Tabla 3). 


\section{ANÁLISIS DEL IMPACTO DE LOS SISTEMAS DE FREE-FLOATING CARSHARING EN ENTORNOS URBANOS UTILIZANDO DATOS WEB: APLICACIÓN A LA CIUDAD DE MADRID}
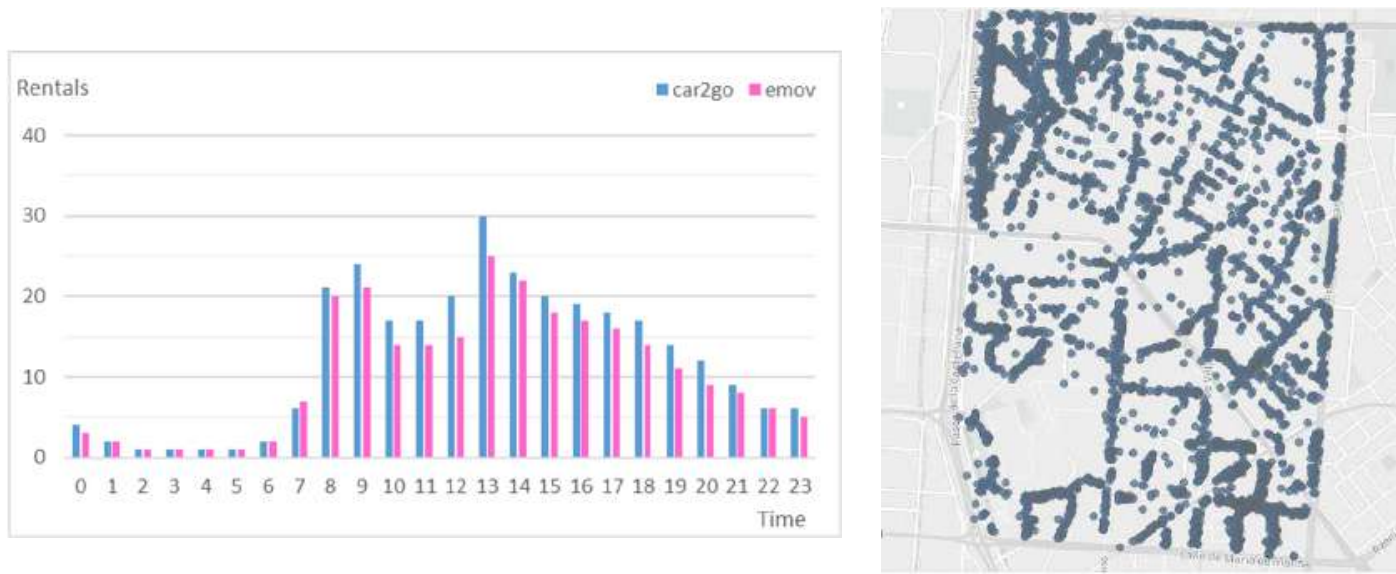

(a)
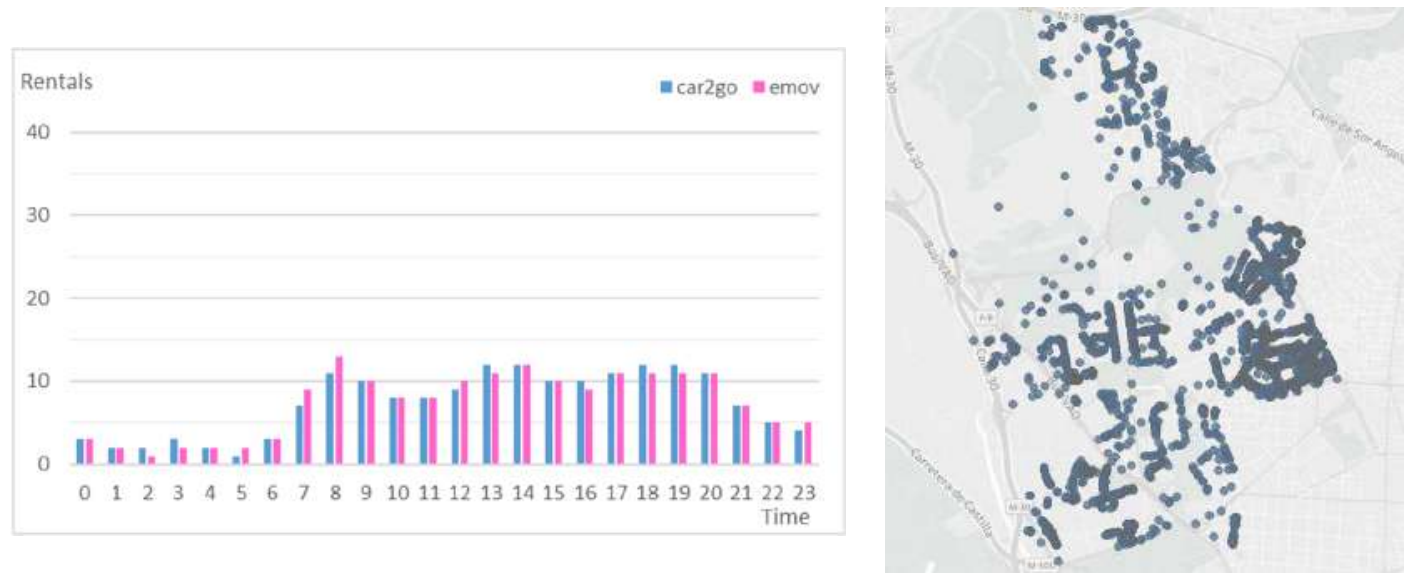

(b)
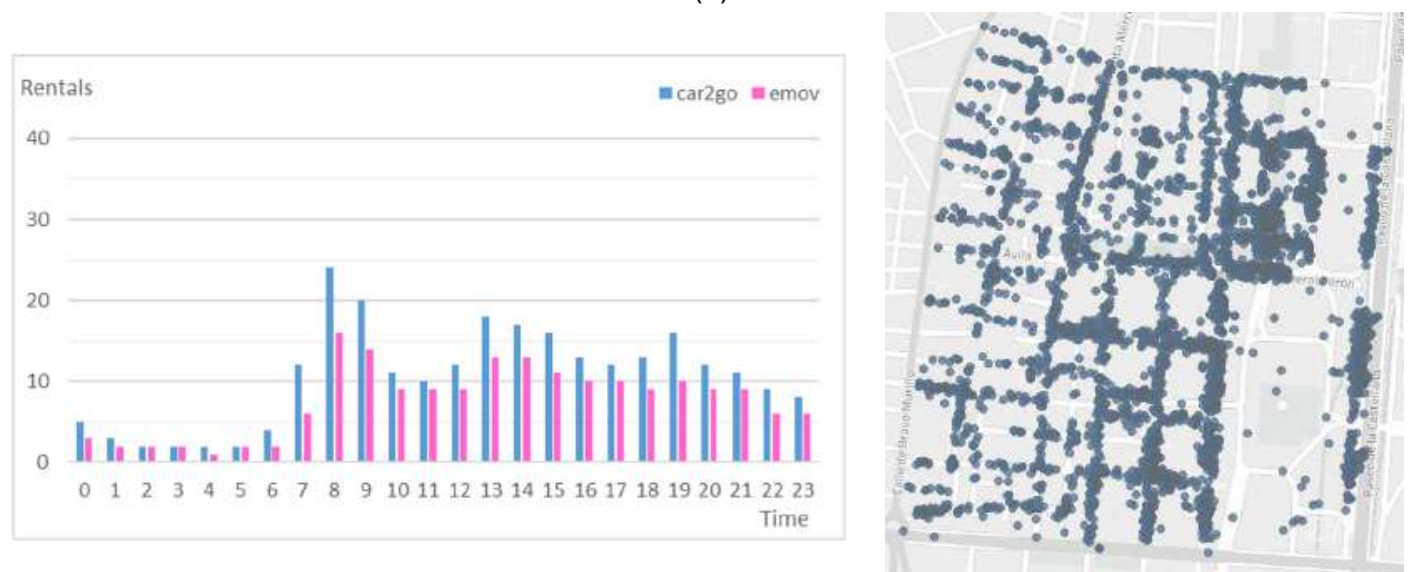

(c)

Figura 19. Promedio de viajes en día laborable y ubicación de las coordenadas de origen de los viajes durante el periodo de tiempo estudiado en (a) El Viso (051), (b) Ciudad Universitaria (093) y (c) Cuatro Caminos (062). 
Tabla 3. Variables socioeconómicas de los barrios analizados, de los distritos de la Almendra Central y de la ciudad de Madrid. Fuente: Ayuntamiento de Madrid.

\begin{tabular}{|c|c|c|c|c|c|}
\hline & $\begin{array}{c}\text { El Viso } \\
\text { (051) }\end{array}$ & $\begin{array}{c}\text { Ciudad } \\
\text { Universitaria } \\
(093)\end{array}$ & $\begin{array}{c}\text { Cuatro } \\
\text { Caminos } \\
(062)\end{array}$ & $\begin{array}{c}\text { Distritos } \\
01-07\end{array}$ & $\begin{array}{l}\text { Municipio } \\
\text { de Madrid }\end{array}$ \\
\hline Área (ha) & 170,9 & $1.425,1$ & 118,5 & 4.178 & 60.446 \\
\hline Población (habitantes) & 17.145 & 16.097 & 34.254 & 988.817 & 3.221 .824 \\
\hline Densidad de población (hab/ha) & 100,31 & 11,30 & 289,05 & 236,68 & 53,30 \\
\hline Género: Mujeres/hombres (\%) & $54,7 / 45,3$ & $54,6 / 45,4$ & $54,9 / 45,1$ & $54,3 / 45,7$ & $53,4 / 46,6$ \\
\hline $\begin{array}{l}\text { Grupos de edad: 0-14/15-29/30-44 / } \\
45-64 / 65+\text { años (\%) }\end{array}$ & $\begin{array}{c}13 / 17 / 21 / \\
28 / 21\end{array}$ & $\begin{array}{l}12 / 17 / 19 / \\
26 / 25\end{array}$ & $\begin{array}{l}10 / 16 / 25 / \\
26 / 23\end{array}$ & $\begin{array}{l}11 / 15 / 25 / \\
27 / 22\end{array}$ & $\begin{array}{l}14 / 15 / 23 / \\
28 / 20\end{array}$ \\
\hline Población con estudios universitarios (\%) & 50,0 & 49,8 & 42,8 & 42,8 & 28,6 \\
\hline Hogares (número) & 6.060 & 6.103 & 14.866 & 427.246 & 1.278 .258 \\
\hline Renta media annual por hogar $(€)$ & 103.573 & 67.390 & 43.306 & 45.389 & 38.535 \\
\hline Calidad de vida declarada (0-100) & 81,6 & 79,7 & 66,8 & 74,6 & 69,5 \\
\hline
\end{tabular}

Fuentes: Portal de Datos Abiertos del Ayuntamiento de Madrid y

Encuesta de Calidad de Vida y Satisfacción con los Servicios Públicos de la Ciudad de Madrid 2017

El Viso es un barrio perteneciente al Distrito de Chamartín. Es una zona fundamentalmente residencial con edificaciones unifamiliares, algo poco habitual dentro de la Almendra Central. Por este motivo, su densidad de población (100 habitantes/ha) es inferior a la de los barrios que forman parte del mismo distrito (de media, $158 \mathrm{hab} . / \mathrm{ha}$ ) y a la de los distritos situados dentro de la Almendra Central (237 hab./ha). Esto hace que la demanda de espacios de aparcamiento en el viario por parte de los residentes sea reducida y haya espacio disponible para vehículos de FFCS. Es uno de los barrios con renta media por hogar más alta de la ciudad (103.573 $€)$, superando con creces la media de la Almendra Central (45.389 €) y de la ciudad (38.535 €), lo que podría llevar a una mayor disposición al pago. Además de esto, se sitúa junto a importantes puntos de interés de la ciudad ubicados en torno al Paseo de la Castellana. Esto hace que El Viso, gracias a la facilidad para encontrar aparcamiento, pueda atraer viajes de FFCS cuyo destino final no se encuentra en el propio barrio, sino en zonas cercanas.

El segundo de los barrios analizados es Ciudad Universitaria, perteneciente al Distrito de Moncloa-Aravaca y en él se ubica el campus universitario que sirvió como escenario en la etapa inicial de esta investigación. El área del campus alberga edificios universitarios, así como extensas zonas verdes y elevada oferta de aparcamiento, aunque el Este y Norte del barrio es mayoritariamente residencial. Pese a no ser una zona céntrica, el campus está bien conectado con otras áreas de la ciudad gracias a la M-30. No obstante, en el periodo de tiempo analizado se generaron más viajes en la zona residencial donde se encuentran edificios de apartamentos y algunas residencias 


\section{ANÁLISIS DEL IMPACTO DE LOS SISTEMAS DE FREE-FLOATING CARSHARING EN ENTORNOS URBANOS UTILIZANDO DATOS WEB: APLICACIÓN A LA CIUDAD DE MADRID}

de estudiantes. A pesar de su gran extensión, el barrio sólo tiene 16.097 habitantes censados, pero esta cifra no incluye a los estudiantes que viven en el barrio y, como ya se analizó, son potenciales usuarios de estos sistemas, por ser gente joven con permiso de conducir y, en la mayoría de los casos, sin vehículo propio (AmpudiaRenuncio, Guirao y Molina-Sánchez, 2018). Además, la zona residencial carece de una buena oferta de transporte público, por lo que hace que los sistemas FFCS sean convenientes. En cuanto a la distribución media de viajes generados en un día laborable, la curva es más suave que la de la ciudad entera, indicando que se producen viajes con regularidad a lo largo del día.

En tercer lugar, se analizó el barrio de Cuatro Caminos que forma parte del Distrito de Tetúan. Es una zona con mayor densidad de población (289 hab./ha) y menor renta media por domicilio (43.306 €) que los barrios anteriores, aunque sigue estando por encima de la media de la ciudad $(38.535 €)$. Pese a ser un área con elevada densidad de población, en ella también se encuentra una de las principales zonas empresariales de la ciudad, junto al Paseo de la Castellana. Precisamente es en los espacios de aparcamiento de esta área donde se ubicaron más vehículos FFCS en el periodo de tiempo analizado. La distribución diaria de viajes en Cuatro Caminos es similar a la de la ciudad entera, con tres periodos punta a lo largo de un día laborable. El periodo punta de la mañana corresponde a los viajes realizados por los residentes del barrio y los del mediodía y de la tarde corresponde a la intensa actividad de las oficinas.

Tras analizar las peculiaridades de estos y otros barrios que son orígenes y destinos recurrentes, se puede concluir que son zonas preferentemente residenciales con densidad de población situada en la media de la ciudad o por encima de esta, y con alta renta. En algunos casos, estos barrios podrían no ser el verdadero origen o destino de los viajes, pero gracias a su ubicación privilegiada cerca de puntos de atracción, como zonas de oficinas o comerciales, o cerca de intercambiadores de transporte público, puede que los usuarios se dirijan a ellos por su disponibilidad de aparcamiento. Éste es un factor muy importante en el éxito de los sistemas FFCS, pues al observar las ubicaciones de las coordenadas exactas de origen de los viajes, se observa que tienden a estar aparcados en arterias principales que están bien conectadas y donde hay suficiente oferta de aparcamiento.

Hay que destacar que, aunque la adquisición de datos a partir de las APls de los operadores es la mejor fuente de datos de la que disponemos, estamos perdiendo la información de los orígenes y destinos reales de los viajes. Este tipo de información debe analizarse con cautela y no se deben sacar conclusiones sin conocer las peculiaridades del lugar y del sistema de FFCS. 


\section{BLOQUE VI. CONCLUSIONES Y FUTURAS LÍNEAS DE INVESTIGACIÓN}

Debido a la creciente demanda de los nuevos sistemas de FFCS, existe una opinión generalizada entre la comunidad científica de que los resultados de las investigaciones acerca del carsharing tradicional no pueden ser transferidos directamente al FFCS. Los impactos positivos que el FFCS ha generado en el transporte público de las ciudades no están del todo claros y el papel de las Administraciones locales en potenciar o frenar el acceso prioritario del FFCS al aparcamiento en el viario público es una cuestión clave para su futuro desarrollo.

En la etapa preliminar de esta investigación, las observaciones secuenciales revelaron que la disponibilidad de vehículos en el campus universitario se incrementaba un tiempo después de la hora punta de la mañana en día laborable, lo que es razonable teniendo en cuenta que estos sistemas facturan por minuto, por lo que la congestión hace que sean menos competitivos. El grupo de población objetivo en esta fase de la investigación fue una muestra limitada de estudiantes universitarios, que tienen cierta flexibilidad en sus horarios, por lo que podrían evitar moverse en FFCS en los periodos de mayor tráfico. La ubicación de las estaciones de transporte público y el inventario de espacio de aparcamiento en Ciudad Universitaria resultó ser una información clave para entender la distribución espacial de los vehículos disponibles representados en la web del operador analizado (Car2go).

La campaña de encuestas realizada proporcionó información acerca de la fiabilidad de los sistemas FFCS, comparándola con resultados de una encuesta similar llevada a cabo en Hamburgo. En otros modos de transporte, la fiabilidad está ligada a la frecuencia y puntualidad del servicio, pero en el caso del FFCS significa que deba haber un nivel de coches disponibles y a una determinada distancia, tal que permita que un usuario pueda alquilar un vehículo que se encuentre a una distancia que esté dispuesto a caminar. Además, si no hubiera un vehículo disponible dentro del radio de distancia deseado, la fiabilidad tendría que ver con el tiempo máximo que el usuario esperaría hasta que apareciese otro coche en la app y la oferta de modos de transporte alternativos en el caso de que ese tiempo se supere. Los resultados de Hamburgo y Madrid mostraron rangos similares de respuesta: existe una distancia admisible de $500 \mathrm{~m}$, a partir de la cual más del $80 \%$ de los encuestados en ambos casos no alquilarían un coche; y en torno a un $95 \%$ no aceptaría esperar un tiempo superior a 30 minutos. Se obtuvieron porcentajes similares en ambos estudios cuando se preguntó acerca del modo de transporte alternativo si finalmente no se utiliza un vehículo de FFCS: el $80 \%$ admitió que usaría transporte público, revelando que un sistema de estas características no podría ser implementado con éxito en una ciudad que carezca de una red de transporte público con una mínima calidad de servicio. Es probable que, cuando un nuevo cliente de un sistema FFCS viene de ser usuario del transporte público tenga mayor tolerancia a caminar y esperar que cuando la 
transferencia se produce desde el vehículo privado, pero se requiere más investigación para conocer el perfil de los usuarios de FFCS como antiguos viajeros de transporte público. En este estudio se observó que un incremento de la disposición a andar para alquilar un vehículo podría aumentar significativamente la oferta de vehículos disponibles: por ejemplo, la oferta aumentaría un $70 \%$ al pasar de una distancia de 500 a $700 \mathrm{~m}$. La disposición a caminar es muy importante, y ello supone que no podemos obviar el estudio y la mejora de los itinerarios peatonales en las ciudades que tienen sistemas de FFCS. En un futuro, los resultados de esta investigación podrían contrastarse con los obtenidos en una campaña de encuestas que tenga un tamaño de muestra mayor y cuya población sea más diversa. La selección de los encuestados debería incluir otros grupos de población o, en el caso de volver a replicarse exclusivamente en el Campus, debería incluir alumnos de otras titulaciones, incluyendo estudiantes de centros universitarios con una oferta de aparcamiento más limitada que la que existe junto a la Escuela de Caminos, Canales y Puertos.

Con la obtención de los datos procedentes de las páginas web de los operadores y el posterior proceso de identificación de viajes, la investigación se encaminó hacia el análisis de la distribución temporal y espacial de los viajes en toda la ciudad. Los estudios que usan métodos basados en datos web para analizar los flujos de FFCS son escasos, ya que la mayoría se basan en encuestas y simulaciones. En este caso, se diseñó una plataforma y se definieron los criterios necesarios para identificar viajes. Se extrajeron datos durante meses de los dos operadores que operaban en ese momento en la ciudad, de los que finalmente se utilizó un conjunto de datos de 20 semanas. El análisis del perfil temporal de los viajes muestra que, a diferencia de otras ciudades, Madrid presenta un periodo punta después del mediodía, además de los periodos punta de la mañana y de la tarde. Ello refleja que los horarios laborales y las peculiaridades de cada ciudad o país (en España, la comida principal del día se realiza en la franja 13:30-15:30) se reflejan en el uso de FFCS.

Se analizó también el comportamiento de los usuarios mediante la representación de las distribuciones de reservas en las que no se produjeron viajes, así como aquellas que sí resultaron en un viaje. En el caso de las primeras, se observa que la mayoría de las cancelaciones se produjeron en los minutos iniciales de la reserva y la curva desciende gradualmente hasta llegar al máximo tiempo de reserva permitido por los operadores. En cuanto a la duración de los registros que sí corresponden a viajes, se obtuvo que el tiempo medio es de 27 minutos, incluyendo el tiempo de reserva previo, aunque la curva presenta una cola hacia la derecha debida, probablemente, a la posibilidad de reservar un vehículo durante un día completo a una tarifa reducida. También se compararon los tiempos de viaje con los de las rutas óptimas de los modos de transporte público de la ciudad, entendiendo que el FFCS tiende a actuar como sustituto del transporte público, especialmente en recorridos entre zonas relativamente cercanas en los que el tiempo en transporte público se duplica. La 
competencia entre el FFCS y el transporte público requiere más investigación, con datos que recojan el origen y el destino real de los viajes (y no solo el origen y destino en el alquiler del vehículo FFCS).

Con respecto a la distribución espacial de los viajes, se observaron zonas en las que apenas se generaron y atrajeron viajes en este periodo. Entre otros motivos, esto pudo deberse a las dificultades de aparcamiento que existen o existían en estas áreas. Por otro lado, se comprobó que los barrios situados junto al Paseo de la Castellana, así como otros barrios como Ciudad Universitaria, el volumen de viajes generados y atraídos fue considerable. Posteriormente, se seleccionaron tres de estos barrios (El Viso, Cuatro Caminos y Ciudad Universitaria) para llevar a cabo un análisis a nivel de unidad espacial. Tras evaluar sus peculiaridades, se puede concluir que las zonas con mayores tasas de utilización son vecindarios con renta media-alta, alta oferta de aparcamiento y buena conectividad con la infraestructura vial urbana. Este resultado nos llevaría a un debate acerca de los problemas de equidad social que este modelo de transporte puede generar, al no ser igualmente accesible para todos los ciudadanos debido a su nivel de renta.

Esta tesis por artículos constituye el primer estudio de los sistemas Free-Floating Carsharing en la ciudad de Madrid y el objetivo es seguir evaluando los impactos de estos sistemas en la capital española, tras la irrupción de nuevos operadores con áreas de servicio más extensas y diversas tipologías de procesos de alquiler de vehículos. Investigaciones futuras podrían implicar la mejora de la plataforma de adquisición de datos web para extraer información de dichas empresas que han entrado posteriormente en el mercado, así como para incorporar datos de los sistemas de transporte público de la ciudad. El diseño de plataformas web para recolectar datos es imprescindible, pero, como se ha demostrado, también es necesario el planteamiento de una serie de hipótesis sobre algunos procesos que no se pueden interpretar de forma sistemática (viajes abortados, viajes por motivos de recarga, viajes con origen y destino el mismo barrio, etc.). Por ello, en esta tesis también se ha apuntado que el diseño de plataformas web debe complementarse con campañas de encuestas a los usuarios. Para ello, se necesita la colaboración de las empresas operadoras con el fin de obtener una muestra estadística representativa de sus usuarios. Esta es una fase de la investigación en la que los equipos de trabajo no deberían avanzar en soledad, sin contar con el respaldo tanto de las Administraciones locales como de las propias empresas operadoras. Desde el punto de vista metodológico, como está ocurriendo en muchas investigaciones recientes vinculadas a la movilidad urbana, necesitamos pasar del "geoposicionamiento del vehículo" para analizar los viajes, a un "tracking" del viajero a través de su Smartphone para conocer el origen y destino final de los desplazamientos. Tecnológicamente, este tipo de plataformas de Big Data están disponibles, pero se necesita la colaboración de la población y que esta cesión de información esté incentivada por las autoridades locales. 


\section{ANÁLISIS DEL IMPACTO DE LOS SISTEMAS DE FREE-FLOATING CARSHARING EN ENTORNOS URBANOS UTILIZANDO DATOS WEB: APLICACIÓN A LA CIUDAD DE MADRID}

En el caso de Madrid, los trabajos futuros sobre FFCS también deberían implicar la investigación de los efectos de la implementación de Zonas de Bajas Emisiones, como Madrid Central, en el funcionamiento de estos sistemas que utilizan vehículos eléctricos o híbridos. Cuando se adquirieron los datos utilizados en este estudio, esta zona no era un origen y destino frecuente debido a la reducida oferta de aparcamiento, pero este hecho podría haber cambiado tras la entrada en vigor de las nuevas regulaciones aprobadas por el consistorio local.

Este trabajo también revela que la distribución de los flujos en una ciudad es muy dependiente de su configuración urbana. Por este motivo, las comparaciones entre ciudades con sistemas FFCS en aspectos relativos a la disponibilidad del servicio y a la distribución espacial de los flujos deben hacerse con cautela. Además de la estructura de la propia ciudad y las características de su infraestructura viaria y de aparcamiento, influyen otros factores como las regulaciones de aparcamiento y su tarificación. Los inventarios de las plazas de aparcamiento en cada barrio o zona de la ciudad podrían constituir una información importante para entender cómo se reparten los movimientos de FFCS en la ciudad.

Aunque no está demostrado que el FFCS tenga el efecto positivo que el carsharing tradicional tiene en la reducción de la posesión de vehículos y en las distancias individuales recorridas, las administraciones locales deberían promover su uso de una forma complementaria al transporte público. No hay duda de que, en Madrid, con flotas completamente eléctricas, estos sistemas tienen un impacto positivo en la calidad del aire. Sin embargo, la reducción de la congestión implica aumentar la concienciación para que los ciudadanos no dependan tanto sus vehículos privados y usen más transporte público combinado con otros modos de transporte sostenibles.

A efectos prácticos, para los responsables de la planificación y gestión del transporte, como consecuencia de los resultados de esta tesis, sería necesaria hacer una reflexión y discusión sobre algunas inquietudes que suscita la puesta en marcha de estos sistemas. En primer lugar, las posibilidades reales que ofrece este modo de transporte para ser extensivo y accesible a toda la población, que están condicionadas por las zonas de operación en la ciudad, y la necesidad del manejo de nuevas tecnologías para acceder a su uso. También la escasa disponibilidad de aparcamiento en viario urbano en ciertos barrios de la ciudad condiciona el acceso a su uso por la población que habita estos barrios. La segunda reflexión tendría que centrarse en el impacto de estos nuevos sistemas podrían tener en las formas urbanas, sobre todo en la sección transversal del viario urbano: hablamos de la necesidad de aparcamientos especiales (más pequeños, de acuerdo con el tamaño de vehículos FFCS) o de la viabilidad de señalizar carriles exclusivos en ciertas calles para la circulación de estos vehículos (al igual que los VAO, Vehículos de Alta Ocupación).

También debería existir una discusión en torno a la necesidad de regular con nuevos criterios estas formas de movilidad en vehículo compartido. El viaje compartido en estos vehículos (varias personas por coche FFCS) debería estar incentivado por las 
autoridades municipales. Es necesaria, además, una reflexión acerca de la regulación del aparcamiento en las ciudades. Hasta ahora, en Madrid, por ejemplo, se incentiva el aparcamiento del vehículo más sostenible, pero no el comportamiento del usuario más sostenible (por ejemplo, aparcar un vehículo que ha sido utilizado en un viaje compartido). Estas reflexiones deben trascender el ámbito académico/científico para a la acción en el ámbito de la planificación del transporte y la gestión del aparcamiento en viario urbano.

Para concluir esta tesis doctoral, debe ponerse en manifiesto que este último capítulo fue redactado en el año 2020, en plena situación de pandemia a nivel mundial debido al coronavirus. Durante el confinamiento de la población en los hogares, la movilidad en Madrid disminuyó drásticamente. Además, el mercado laboral tuvo que adaptarse a la situación de teletrabajo a gran escala; en algunos casos, con resultados positivos como la reducción de los niveles de contaminación en las principales ciudades del mundo. Este evento histórico afectará al comportamiento de la movilidad no sólo en los próximos meses, sino también en la próxima década, lo que presumiblemente reducirá los viajes de desplazamiento por motivo de trabajo en un alto porcentaje de puestos de trabajo. Es probable que esta experiencia cambie temporalmente la percepción que los usuarios tienen del coche compartido, del viaje compartido y del FFCS en concreto, como tipología del carsharing. Desde el punto de vista científico, esta situación supone nuevos retos de estudio y análisis de la movilidad urbana que, en el caso del FFCS, se añadirán a los retos y futuras líneas de investigación anteriormente descritas. 


\section{REFERENCIAS}

Ahmed, S., 2019. What has been the impact of Madrid Central on road usage and emissions since its implementation in November 2018? Disponible en: https://www.academia.edu/38808618/What_has_been_the_impact_of_Madrid_Central _on_road_usage_and_emissions_since_its_implementation_in_November_2018

Ampudia-Renuncio, M., Guirao, B., Molina-Sánchez, R., 2018. The impact of FreeFloating Carsharing on sustainable cities: analysis of first experiences in Madrid with the university campus. Sustainable Cities and Society, 43, 462-475.

Ampudia-Renuncio, M., Guirao, B., Molina-Sánchez, R., de Álvarez, C. E., 2020a. Understanding the spatial distribution of Free-Floating Carsharing in cities: Analysis of the new Madrid experience through a web-based platform. Cities, 98, 102593.

Ampudia-Renuncio, M., Guirao, B., Molina-Sánchez, R., Bragança, L., 2020b. Electric Free-Floating Carsharing for sustainable cities: Characterization of frequent trip profiles using acquired rental data. Sustainability, 12(3), 1248.

Ayuntamiento de Madrid, 2005. Ordenanza de Movilidad para la Ciudad de Madrid. Acuerdo Pleno de 26 de septiembre 2005. B.O. Ayuntamiento de Madrid de 1 de diciembre de 2005 núm 5680, 4504-4521. Disponible en: https://www.madrid.es/UnidadesDescentralizadas/UDCMovilidadTransportes/SER/Fich eros\%20nuevo\%20SER\%202014/Ordenanza\%20de\%20Movilidad.pdf

Ayuntamiento de Madrid, 2016a. Memoria 2016 Calidad del Aire. Dirección General de Sostenibilidad y Control Ambiental. Disponible en: http://www.mambiente.munimadrid.es/opencms/export/sites/default/calaire/Anexos/Me morias/Memoria2016.pdf

Ayuntamiento de Madrid, 2016b. Ordenanza Fiscal Reguladora de la Tasa por Estacionamiento de Vehículos en Determinadas Zonas de la Capital y de delimitación de la Zona de Estacionamiento Regulado. Acuerdo Pleno de 9 de octubre 2001. Modificada por Acuerdo Pleno de 29 de diciembre de 2016. BOCM núm. 351 de 31 de diciembre de 2016. Disponible en: https://sede.madrid.es/UnidadesDescentralizadas/UDCMovilidadTransportes/SER/Des criptivos/ficheros/Ordenanza\%20Fiscal\%20SER\%2031-12-2016.pdf

Ayuntamiento de Madrid, 2018. Ordenanza de Movilidad Sostenible. Acuerdo Pleno de 5 de octubre de 2018. BOCM núm. 253 de 23 de octubre de 2018. Disponible en: https://sede.madrid.es/FrameWork/generacionPDF/ANM2018_45.pdf?idNormativa=5cc db732cef96610VgnVCM2000001f4a900aRCRD\&nombreFichero=ANM2018_45\&cach eKey=212

Ayuntamiento de Madrid, 2019. Memoria 2019 Calidad del Aire. Dirección General de Sostenibilidad y Control Ambiental. Disponible en: 
http://www.mambiente.madrid.es/opencms/export/sites/default/calaire/Anexos/Memoria s/Memoria_2019.pdf

Bardhi, F., Eckhardt, G. M., 2012. Access-based consumption: The case of car sharing. Journal of consumer, 39(4), 881-898.

Becker, H., Ciari, F., Axhausen, K.W., 2017. Comparing car-sharing schemes in Switzerland: User groups and usage patterns. Transportation Research Part A, Policy and Practice 97, 17-29.

Botsman, R., Rogers, R., 2010. Beyond Zipcar: Collaborative Consumption. Harvard Business Review, 88 (10), 30.

Car2go blog, 2018a. We are three million! Disponible en: https://blog.car2go.com/2018/02/07/we-are-3-million/.

Car2go blog, 2018b. Daimler and BMW - The parent companies of car2go and DriveNow - Signed an agreement to form a joint venture. Disponible en: https://blog.car2go.com/2018/03/28/daimler-and-bmw-the-parent-companiesof car2goand-drivenow-signed-an-agreement-to-form-a-joint-venture/.

Ciari, F., Bock, B., Balmer, M., 2014. Modeling station-based and free-floating carsharing demand: test case study for Berlin. Transportation Research Record 2416 (1), $37-47$.

Ciari, F., Balac, M., Balmer, M., 2015. Modelling the effect of different pricing schemes on free-floating carsharing travel demand: A test case for Zurich, Switzerland. Transportation, 42(3), 413-433.

Ciociola, A., Cocca, M., Giordano, D., Mellia, M., Morichetta, A., Putina, A., Salutari, F., 2017. UMAP: Urban mobility analysis platform to harvest car sharing data. In Proceedings of the 2017 IEEE SmartWorld, Ubiquitous Intelligence \& Computing, Advanced \& Trusted Computed, Scalable Computing \& Communications, Cloud \& Big Data Computing, Internet of People and Smart City Innovation, San Francisco, CA, USA, 4-8 August 2017, 1-8.

Delbosc, A., 2017. A tale of two millennials. Journal of Transport and Land Use, 10(1), 903-910.

Dempsey, A., 2016. Why are millennials buying fewer cars? Tesis Doctoral. The Ohio State University.

DriveNow blog, 2017. DriveNow celebrates its 1 millionth customer! Disponible en: https://www.drive-now.com/gb/en/blog/one-million-customers.

Firnkorn, J., Müller, M., 2011a. Selling mobility instead of cars: New business strategies of automakers and the impact on private vehicle holding. Business Strategy and the Environment, 21(4), 264-280. 


\section{ANÁLISIS DEL IMPACTO DE LOS SISTEMAS DE FREE-FLOATING CARSHARING EN ENTORNOS URBANOS UTILIZANDO DATOS WEB: APLICACIÓN A LA CIUDAD DE MADRID}

Firnkorn, J., Müller, M., 2011b. What will be the environmental effects of new FreeFloating Car-Sharing systems? The case of car2go in Ulm. Ecological Economics 70 (8), 1519-1528.Firnkorn, J., 2012. Triangulation of two methods measuring the impacts of a freefloating carsharing system in Germany. Transportation Research Part A: Policy and Practice, 46(10), 1645-1672.

Guirao, B., García, A., López, M.E., Acha, C., Comendador, J, 2015. New QR survey methodologies to analyze user perception of service quality in public transport: The experience of Madrid. Journal of Public Transportation 18 (3), 71-88.

Habibi, S., Sprei, F., Englundn, C., Pettersson, S., Voronov, A., Wedlin, J., Engdahl, H., 2017. Comparison of free-floating car sharing services in cities. European Council of Energy Efficient Economy Summer Study, 771-778.

Haefeli, U., Matti, D., Schreyer, C., Maibach, M., 2006. Evaluation car-sharing. Federal Department of the Environment, Transport. Energy and Communications, Bern.

Herrmann, S., Schulte, F., Voß., S., 2014. Increasing acceptance of free-floating carsharing systems using smart relocation strategies: A survey-based study of car2go Hamburg. International conference on computational logistics, pp. 151-162.

Hyundai Motor Europe, 2017. Hyundai electric car sharing starting in Amsterdam with 100 cars. Disponible en: https://www.hyundai.news/eu/model-news/

Hwang, J., Griffiths, M. A., 2017. Share more, drive less: Millennials value perception and behavioral intent in using collaborative consumption services. The Journal of Consumer Marketing, 34(2), 132-146.

Katzev, R., 2003. Car sharing: A new approach to urban transportation problems. Analyses of Social Issues and Public Policy, 3(1), 65-86.

Kopp, J., Gerike, R., Axhausen, K.W., 2015. Do sharing people behave differently? An empirical evaluation of the distinctive mobility patterns of free-floating car-sharing members. Transportation 42 (3), 449-469.

Kortum, K., Schönduwe, R., Stolte, B., Bock, B., 2016. Free-Floating Carsharing: City Specific Growth Rates and Success Factors. Transportation Research Procedia, 19, 328-340.

Lamberton, C. P., Rose, R. L., 2012. When is ours better than mine? A framework for understanding and altering participation in commercial sharing systems. Journal of Marketing, 76(4), 109-125.

Martin, E., Shaheen, S., 2011. Greenhouse gas emission impacts of carsharing in North America. IEEE Transactions on Intelligent Transportation Systems 12 (4), 10741086.

Martin, E., Shaheen, S., 2016. The impacts of Car2go on vehicle ownership, modal shift, vehicle miles traveled, and greenhouse gas emissions: An analysis of five North American cities. UC Berkeley: Transportation Sustainability Research Center. 
Millard-Ball, M., Murray, G., Ter Schure, J., Fox, C., Burkhardt, J., 2005. Car-sharing: Where and how it succeeds. Transit cooperative research program report 108. Transportation Research Board.

Müller, J., Schmöller, S., Giesel, F., 2015. Identifying users and use of (electric) FreeFloating Carsharing in Berlin and Munich. In: IEEE Conference Publications (18th International Conference on Intelligent Transportation Systems), 2569-2573.

Müller, J., Correia, G., Bogenberger, K., 2017. An explanatory model approach for the spatial distribution of free-floating carsharing bookings: A case-study of German cities. Sustainability, 9(7), 1290.

Naciones Unidas, 2018. Las ciudades seguirán creciendo, sobre todo en los países en desarrollo. Disponible en: https://www.un.org/development/desa/es/news/population/2018-worldurbanizationprospects.html

Namazu, M., Dowlatabadi, H., 2018. Vehicle ownership reduction: A comparison of one-way and two-way carsharing systems. Transport Policy, 64, 38-50.

Niels, T., Bogenberger, K., 2017. Booking behavior of free-floating carsharing users: Empirical analysis of mobile phone app and booking data focusing on battery electric vehicles. Transportation Research Record: Journal of the Transportation Research Board 2650, 123-132.

Organización Mundial de la Salud, 2014. Ambient (outdoor) air quality and health. Fact sheet no 313. Updated March 2014. Disponible en: http://www.who.int/mediacentre/factsheets/fs313/en/

Prettenthaler, F. E., Steininger, K. W., 1999. From ownership to service use lifestyle: The potential of car sharing. Ecological Economics, 28(3), 443-453.

PSA Group, 2017. New mobility: PSA presents its mobility services. Disponible en: https://www.groupe-psa.com/en/story/la-liberte-de-mouvement/.

Schmöller, S., Weikl, S., Müller, J., Bogenberger, K., 2015. Empirical analysis of freefloating carsharing usage: The Munich and Berlin case. Transportation Research Part C: Emerging Technologies, 56, 34-51.

Shaheen, S., Sperling, D., Wagner, C., 1998. Carsharing in Europe and North America: Past, Present and Future. UC Berkeley, Earlier Faculty Research.

Shaheen, S., Cohen, P., 2007. Growth in worldwide carsharing: an international comparison. Transportation Research Record 1992 (1), 81-89.

Shaheen, S., Cohen, A., Chung, M., 2009. North American carsharing: 10-year retrospective. Transportation Research Record 2110 (1), 35-44.

Shaheen, S., Micheaux, H., 2015. One-way carsharing's evolution and operator perspectives from the Americas. Transportation 42 (3), 519-536. 


\section{ANÁLISIS DEL IMPACTO DE LOS SISTEMAS DE FREE-FLOATING CARSHARING EN ENTORNOS URBANOS UTILIZANDO DATOS WEB: APLICACIÓN A LA CIUDAD DE MADRID}

Sprei, F., 2018. Disrupting mobility. Energy Research \& Social Science, 37, 238-242.

Sprei, F., Habibi, S., Englund, C., Pettersson, S., Voronov, A., Wedlin, J., 2019. Freefloating car-sharing electrification and mode displacement: Travel time and usage patterns from 12 cities in Europe and the United States. Transp. Res. Part D Transp. Environ., 71, 127-140.

Vaskelainen, T; Münzel, K, 2018. The effect of institutional logics on business model development in the sharing economy: The case of German carsharing services. Academy of Management Discoveries, 4(3), 273-293.

Wang, Y., Yan, X., Zhou, Y., Xue, Q., \& Sun, L., 2017. Individuals' acceptance to freefloating electric carsharing mode: A web-based survey in China. International Journal of Environmental Research and Public Health, 14(5), 476.

Wielinski, G., Trépanier, M., Morency, C., 2015. What about free-floating carsharing? A look at the Montreal, Canada, case. Transportation Research Record, 2563(1), 28-36.

Wielinski, G., Trépanier, M., Morency, C., 2017. Electric and hybrid car use in a freefloating carsharing system. International Journal of Sustainable Transportation, 11(3), 161-169. 